\title{
De raad van commissarissen bij NV en BV
}

Citation for published version (APA):

Blanco-Fernandez, J. M. (1993). De raad van commissarissen bij NV en BV. [Doctoral Thesis, Maastricht University]. Rijksuniversiteit Limburg. https://doi.org/10.26481/dis.19931125jb

Document status and date:

Published: 01/01/1993

DOI:

10.26481/dis.19931125jb

Document Version:

Publisher's PDF, also known as Version of record

\section{Please check the document version of this publication:}

- A submitted manuscript is the version of the article upon submission and before peer-review. There can be important differences between the submitted version and the official published version of record.

People interested in the research are advised to contact the author for the final version of the publication, or visit the DOI to the publisher's website.

- The final author version and the galley proof are versions of the publication after peer review.

- The final published version features the final layout of the paper including the volume, issue and page numbers.

Link to publication

\footnotetext{
General rights rights.

- You may freely distribute the URL identifying the publication in the public portal. please follow below link for the End User Agreement:

www.umlib.nl/taverne-license

Take down policy

If you believe that this document breaches copyright please contact us at:

repository@maastrichtuniversity.nl

providing details and we will investigate your claim.
}

Copyright and moral rights for the publications made accessible in the public portal are retained by the authors and/or other copyright owners and it is a condition of accessing publications that users recognise and abide by the legal requirements associated with these

- Users may download and print one copy of any publication from the public portal for the purpose of private study or research.

- You may not further distribute the material or use it for any profit-making activity or commercial gain

If the publication is distributed under the terms of Article $25 \mathrm{fa}$ of the Dutch Copyright Act, indicated by the "Taverne" license above, 
DE RAAD VAN COMMISSARISSEN
BIJ NV EN BV 


\section{DE RAAD VAN COMMISSARISSEN BIJ NV EN BV}

\section{PROEFSCHRIFT}

ter verkrijging van de graad van doctor aan de Rijksuniversiteit Limburg te Maastricht, op gezag van de Rector Magnificus, prof. dr. H. Philipsen volgens het besluit van het College van Decanen, in het openbaar te verdedigen op donderdag 25 november 1993 des namiddags te klokke 4.00 uur

door

José María Blanco Fernández geboren te Orense (Spanje) in 1964 


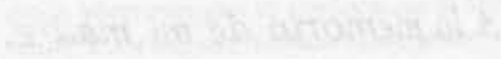

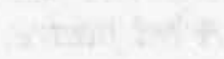




\section{INHOUD}

Inleiding

IX

Hoofdstuk I: Taak van de raad van commissarissen

$\S 1$. De toezichthoudende taak

I. Toezicht in de zin van art. 140/250

II. Toezicht op het beleid van het bestuur en op de algemene gang van zaken in de vennootschap en de met haar verbonden onderneming

III. Collegiale uitoefening van het toezicht

IV. Toezichthoudende organen

\$2. Advies

\$3. Aanvullende taken 23

I. Statutaire vrijheid? 23

II. Vervanging van het bestuur bij ontstentenis of belet 27

III. Vertegenwoordiging van de vennootschap bij tegenstrijdig belang 32

$\S 4$. Richtsnoer bij de taakvervulling: het belang van de vennootschap 38

I. Noodzaak van een standpuntbepaling 38

II. De rechtspersoon: contract noch instituut $\quad 39$

III. Het belang van de vennootschap 42

Hoofdstuk II: Bevoegdheden van de raad van commissarissen $\quad 53$

\$5. Raad van Commissarissen en prioriteit 54

$\$ 6$. Benoeming, schorsing en ontslag van commissarissen. Verwijzing 58

$\$ 7$. Benoeming, schorsing en ontslag van bestuurders 58

I. Benoeming van bestuurders $\quad 60$

II. Schorsing van bestuurders $\quad 66$

III. Ontslag van bestururders 68

$\$ 8$. Bevoegdheden met betrekking tot de jaarrekening 71

I. Vaststelling van de jaarrekening $\quad 71$

II. Benoeming van de accountant 76

§9. Goedkeuring van bestuursbesluiten $\quad 77$

I. Onderwerp van de goedkeuring 78

II. Het goedkeuringsbesluit. $\quad 82$

\$10. Recht op informatie $\quad 85$

\$11. Andere bevoegdheden $\quad 88$ 
Hoofdstuk III: Samenstelling van de raad van commissarissen

$\$ 12$. Aard van de rechtsverhouding tussen commissaris en vennootschap 93

$\$ 13$. Het gewone model

I. Benoeming van commissarissen

II. Schorsing en ontslag van commissarissen 104

\$14. Het structuurmodel

I. Benoeming van commissarissen 107

a) Benoemingscontracten $\quad 109$

b) Benoemingsprocedure $\quad 115$

c) De commissie van aandeelhouders $\quad 119$

II. Schorsing van commissarissen 122

III. Ontslag van commissarissen 124

\$15. Behoorlijke samenstelling $\quad 126$

I. Algemeen 126

II. Benoembaarheid 128

III. Kwaliteitseisen 133

IV. De bezwaargronden van art. 158/268 lid 6

\$16. Bijzondere gevallen $\quad 147$

I. President-commissaris 148

II. Gedelegeerde commissaris 151

III. Overheidscommissaris $\quad 154$

IV. Regeringswaarnemer 160

Hoofdstuk IV: Taakvervulling en aansprakelijkheid 165

\$17. Aansprakelijkheid wegens onbehoorlijke taakvervulling 166

1. Aansprakelijkheid jegens de rechtspersoon 166

a) Onbehoorlijke taakvervulling $\quad 167$

b) Verwijtbaarheid 173

II. Aansprakelijkheid jegens de vennootschapsboedel in geval van $\begin{array}{ll}\text { faillissement } & 181\end{array}$

a) Grondslag van de aansprakelijkheid ex art. 138

b) Kennelijk onbehoorlijke taakvervulling 191

c) Collectieve verantwoordelijkheid en hoofdelijke aansprakelijkheid

\$18. Tegenstrijdig belang van een commissaris met de vennootschap 200

$\begin{array}{ll}\text { Samenvatting } & 209\end{array}$

Summary

$\begin{array}{ll}\text { Lijst van aangehaalde jurisprudentie } & 217\end{array}$

Lijst van geraadpleegde literatuur $\quad 221$

Zakenregister 


\section{INLEIDING}

De raad van commissarissen is bij nv en bv het orgaan dat wettelijk belast is met het toezicht op het bestuur van de vennootschap. Het bestaan van een toezichthoudend college is geen essentieel vereiste opdat er sprake is van een volledige 'vennootschappelijke organisatie'. Slechts bij structuurvennootschappen is de raad van commissarissen een wettelijk verplicht orgaan. Voor de gewone vennootschappen, die het leeuwedeel vormen van de Nederlandse vennootschappen, is deze raad een facultatief orgaan. Hoewel derhalve iedere vennootschap een bestuur en een algemene vergadering heeft, kan de raad van commissarissen ontbreken. Wellicht kan worden gesteld dat in de vennootschapspraktijk dit controlerend orgaan eerder uitzondering dan regel is.

Een andere bijzonderheid kenmerkt de rechtspositie van de raad van commissarissen. Deze bijzonderheid is gelegen in de abstractheid van zijn functie. Het is eenvoudiger zich een voorstelling te maken van hetgeen het besturen van een vennootschap inhoudt, dan van hetgeen de controle op het bestuur betekent. Naar mijn mening is deze vaagheid van de commissariële functie aan de wettelijke regeling niet vreemd.

Bepalend voor de raad van commissarissen is, tot slot, wat men zou kunnen noemen de rechtspolitieke functie van het orgaan. Veelvuldig wordt in de literatuur, en in mindere mate ook in de rechtspraak, deze functie benadrukt. De raad van commissarissen is in deze visie orgaan van de vennootschap, maar hij staat 'los' van de belangen die bij de vennootschap convergeren. De controlerende taak van de raad, zo is de algemene opvatting, wordt bepaald door de onafhankelijkheid van de commissarissen ten opzichte van de bij de vennootschap betrokken belangen. Dit zou de wet met name tot uitdrukking brengen wanneer zij voorschrijft: "Bij de vervulling van hun taak richten de commissarissen zich naar het belang van de vennootschap en de met haar verbonden onderneming" (art. 140 lid 3. Boek 2 BW).

Het veelal facultatief karakter van de raad van commissarissen, de onbestemdheid van zijn taak en een naar mijn mening verkeerde opvatting van het criterium waarnaar zijn takkervulling zich dient te richten, lijken mij de belangrijkste oorzaken van de bestaande onduidelijkheid omtrent de rechtspositie van dit orgaan.

In deze studie wordt een poging gewaagd om hierin enige klaarheid te brengen. Ik meen dat dit slechts mogelijk is door het positieve recht als uitgangspunt van de analyse te nemen. Ons vennootschapsrecht is, primair, positief recht. Mede hierdoor heeft het onderzoek geen rechtsvergelijkende 
pretentie. Escapades naar andere rechtsstelsels worden sporadisch in de noten ondernomen. Bij de interpretatie van de wet ben ik zo veel mogelijk te werk gegaan indachtig het adagium: scire leges non hoc est verba earum tenere, sed vim ac potestatem.

Tot slot: literatuur wordt doorgaans verkort aangehaald. Verwijzing naar wetsartikelen vindt plaats, voor zover niet anders wordt aangegeven, naar Boek 2 BW. Verwezen wordt naar de artikelen omtrent de nv. 


\section{Taak van de raad van commissarissen}

\section{\$ 1. De toezichthoudende taak}

Taak van de raad van commissarissen (rvc) is, volgens art. 140 lid 2, het houden van toezicht op het beleid van het bestuur en op de algemene gang van zaken in de vennootschap en de met haar verbonden onderneming. In deze paragraaf wordt nader ingegaan op de betekenis van deze bepaling.

\section{Toezicht in de zin van artt. $140 / 250$}

De wet geeft niet met zoveel woorden aan wat onder toezicht moet worden verstaan. Veelzeggend is dat, om de juridische inhoud van het begrip te bepalen, schrijvers die zich met het onderwerp hebben bezig gehouden een beroep doen op de taalkundige betekenis van de term. ${ }^{1}$ Andere auteurs achten het zelfs niet goed mogelijk een eenduidige definitie van het begrip te geven. De in de praktijk geconstateerde verscheidenheid aan vennootschappen, commissarissen en toezichtsvormen zou zulks medebrengen. ${ }^{2}$

Voor beide standpunten is, naar mijn mening, iets te zeggen. Enerzijds is het geoorloofd bij de interpretatie van de wet er vanuit te gaan dat de wetgever de woorden van de wet gebruikt in hun taalkundige betekenis. ${ }^{3}$ Doch vanwege het normatieve karakter van de wet is het mogelijk dat haar woorden een andere betekenis hebben dan in het gewone spraakgebruik. Anderzijds is het bezwaar van de pluriformiteit van de feitelijke verhoudingen waarop het wettelijk toezichtsbegrip moet worden toegepast een

1. Vgl. De. Boer (1988), blz. I en Glasz (1992), blz. 17.

2. Zo onder andere, met verschillende stelligheid, Hellema (1965), blz. 11; Grosheide (1969), blz. 45-46 Uniken Venema (1984), blz. 62; Lowensteyn, Rechtspersonen, art. 140 , aant. 4.

3. Larenz (1991), blz. 320. 
omstandigheid waarmee rekening dient te worden gehouden. Dat de rvc zijn toezichthoudende taak conform de omstandigheden van de betrokken vennootschap dient te vervullen, belet mijns inziens echter niet dat de wet aan dit orgaan een concrete taak toekent, die in de praktijk steeds op een andere manier kan worden uitgeoefend. Ook de leidende taak van het bestuur is niet in abstracto te bepalen. Toch wijst reeds het feit dat de wet onderscheid maakt tussen 'toezicht houden' en 'besturen' er op dat beide termen rechtens een eigen betekenis hebben. Ware dit anders en zouden derhalve de schrijvers die het bestaan van een eenduidig toezichtsbegrip ontkennen gelijk hebben, dan zou het onderscheid tussen een besturend en een toezichthoudend orgaan überhaupt niet kunnen worden gemaakt.

Wat het houden van toezicht feitelijk inhoudt, dat wil zeggen welke werkzaamheden het toezicht met zich mee brengt, kan niet uit wet worden afgeleid. $\mathrm{Zij}_{\mathrm{ij}}$ behoeft dat ook niet te bepalen. Dat is de taak van de bedrijfskunde. De wet gebruikt de term toezicht als een terminus technicus. De juridische betekenis van het toezicht moet niet worden verstaan vanuit de feitelijke realiteit die de wet beoogt te regelen, maar vanuit de wet zelf. Het oordeel van de bedrijfskundigen kan wel van belang zijn om de wettelijke regeling te lezen tegen de achtergrond van de maatschappelijke realiteit die ordening behoeft. Ook de handelsgebruiken kunnen daarbij relevant zijn. ${ }^{4}$ Maar de juridische betekenis van het toezicht dient in de wet te worden gevonden.

Mijns inziens dient daarbij het uitgangspunt te zijn dat, zoals Van der Grinten stelt ${ }^{5}$, de rechtspersoon een doelorganisatie is. Dat de rechtspersoon een doelorganisatie is, betekent in eerste instantie dat door middel van de rechtspersoon bepaalde belangen worden gediend. De rechtspersoon is instrument ter realisatie van zekere projecten. Dit doel is het constituerend moment van de rechtspersoon. Het is het doel waarvoor de rechtsgenoten de rechtspersoon tot stand hebben gebracht of in stand houden. Dit eigenlijke doel kan worden onderscheiden van het statutaire 'doel'. Het statutaire doel is de juridische kristallisatie van het voornemen van de oprichters/aandeelhouders. Idealiter komen het eigenlijke doel en het statutaire doel overeen. De rechtspersoon vervult dan de functie waarvoor hij in het leven

4. Waarschijnlijk hield het algemeen verguisde art. 50b WvK een -weliswaar wat ongelukkig geformuleerde- verwijzing naar de handelsgebruiken in. Het artikel luidde: "Als commissaris wordt beschouwd een ieder die, zij het ook onder anderen naam, bij de naamlooze vennootschap eene taak vervult, welke bij eene zoodanige naamlooze vennootschap in den regel aan een commissaris is opgedragen." Hierover schreef Van der Heijden (Handboek, 3de druk 1936, nr. 273): "Door aan de n.v. vrijheid te laten [voor wat betreft de taakomschrijving, JMBF] (...) heeft de wetgever zijn constructie opgehangen aan de lucht."

5. Asser-Van der Grinten $I$, nr. 74. 
is geroepen. Men kan deze verhouding ook aldus aangeven dat het eigenlijke doel, het doel is van de oprichters/aandeelhouder, terwijl het statutaire doel, het doel van de vennootschap is. Het statutaire doel heeft voor de rechtspersoon "normatieve betekenis" ${ }^{16}$ omdat de rechtsgenoten, in de uitoefening van hun vrijheid, daarmee aanwijzen welke de functie van de rechtspersoon is.?

Welnu, de taken en bevoegdheden die aan de verschillende organen binnen de rechtspersoon toekomen, zijn gericht op de verwezenlijking van het eigenlijke doel van de rechtspersoon, zulks conform de oprichters/aandeelhouders in het statutair doel hebben bepaald. ${ }^{8}$ Wanneer de wet bepaalt

6. Zo Van der Grinten, t.a.p. nr. 74.

7. Omtrent de verschillende doelbegrippen bestaat te groot verschil van inzicht om op deze plaats daar in detail op in te gaan. Lowensteyn (1959), blz. 129 e.v. maakt een soortgelijke onderscheiding als in de tekst. Van belang is de door Mendel (Diss. 1971), blz. 35 e.v., besproken verhouding tussen feitelijk en statutaire doel. Mendel schrijft: "Hoe verhouden zich tot elkaar enerzijds het voorwerp der (handels)onderneming van de N.V. en anderzijds het statutaire doel van de N.V.? Zijn deze begrippen identiek of is er verschil? Het eerste is het geval" (curs. ook in het origineel). Het vennootschappelijk doel definieert hij (t.a.p., blz. 36) als: "het blijkens de statuten beoogde werkterrein van de N.V." Deze definitie lijkt mij correct. Het daaraan voorafgaande citaat kan echter tot de verkeerde conclusie leiden dat hetgeen de vennootschap doet (het 'feitelijke' doel) en hetgeen de vennootschap behoort te doen (het 'statutaire' doel) hetzelfde is. Dat beide niet hetzelfde zijn blijkt uit het arrest van het Europees Hof van 13 november 1990, C-106/89, Jur 1990, I-4156 (Marleasing). Volgens A-G Van Gerven zijn zowel de statutaire vermelding als de feitelijke bedrijfsuitoefening als vennootschappelijk doel te beschouwen (vgl. conclusie nrs. 16, 17 en 21: "Onder 'het werkelijke doel van de vennootschap' moet worden verstaan het voorwerp zoals dat in de openbaar gemaakte oprichtingsakte of statuten van de vennootschap is omschreven of zoals dat in de van bij het begin [sic] door de vennootschap daadwerkelijk uitgeoefende activiteit tot uiting komt." Het Hof volgt deze uitleg echter niet. Het vennootschappelijke doel is volgens het Hof "het doel van de vennootschap zoals dat is omschreven in de oprichtingsakte of in de statuten" (nr. 12).

8. In zekere zin kan worden gesteld dat het eigenlijke doel de oorzaak is van de bestuurs- en toezichtsmacht van resp. het bestuur en de rvc. Met name in de landen waar de contractuele opvatting van de nv nog geldt, wordt dit eigenlijke doel als oorzaak van het vennootschapscontract gezien. Vgl. J.C. Saenz, El objeto social en la sociedad anónima, Madrid 1990, blz. 27 e.v. Minder correct m.i., J. Paillusseau, La société anonyme, technique d'organisation de l'enterprise, Paris 1967, blz. 165: "Comme le remarquent très justement (...) la cause du contrat de société parait se confondre avec l'objet social". "l'objet social n'est rien d'autre que l'activité de l'enterprise suivant la définition qu'en donnent les statuts" (mijn curs. JMBF; blz. 164). In zoverre brengt Mendel (Diss. (1971), blz. 44 e.v.), art. 1371 BW oud terecht ter sprake bij de behandeling van het probleem van onbereikbaarheid van het statutaire doel. Wanneer het doel waarvoor de rechtspersoon is

(Wordt vervolgd...) 
dat de rvc toezicht houdt op het beleid van het bestuur, moet mijns inziens de toezichthoudende taak van de rvc aldus worden verstaan, dat dit orgaan er voor dient te zorgen dat het eigenlijke doel van de vennootschap verwezenlijkt wordt binnen het kader van het statutaire doel. Niet de verwezenlijking zelf van het doel is de taak van de rvc, maar het controleren dat de bevoegde organen, met name het bestuur, hun bevoegdheden zodanig uitoefenen dat datgene waarvoor de vennootschap is opgericht gerealiseerd wordt. Hoe de rvc zulks kan doen, en, derhalve, wat het toezicht inhoudt, hangt af van de wettelijke en statutaire ordening van de vennootschap. De wet geeft aan de toezichthoudende taak van de rvc een andere inhoud al naar gelang het een structuurvennootschap betreft of een gewone vennootschap. Bij eerstgenoemde vennootschap heeft de wetgever het noodzakelijk geacht aan het toezichthoudende orgaan belangrijke zeggenschapsrechten te verlenen, in het bijzonder, bij toepasselijkheid van het volledige regime, door toekenning van de bevoegdheid tot benoeming van bestuurders. Waar de rvc niet over deze bevoegdheid beschikt draagt de rvc in zoverre een minder zware verantwoordelijkheid voor het toezicht op het bestuursorgaan, dat hij geen directe zeggenschap heeft over de voor het beleid van de vennootschap direct verantwoordelijke personen. De toezichthoudende taak heeft dan een andere inhoud.

Naast de wettelijke regeling is ook de statutaire inrichting van de vennootschap van belang. Deze omstandigheid is ten gevolge van de institutionele opvatting van de vennootschap in de huidige Nederlandse literatuur mijns inziens onderbelicht gebleven. ${ }^{9}$ De privaatrechtelijke vennootschap, ook de structuurvennootschap, kan desgewenst als een deelrechtsorde ${ }^{10}$ worden aangeduid ${ }^{11}$, maar dan wel als een ordo liberta-

\section{8.(...vervolg)}

opgericht onbereikbaar blijkt te zijn, ontvalt aan de rechtspersoon zijn reden van bestaan. Bij een overeenkomst is deze bestaansreden de oorzaak van de overeenkomst. Vgl. in de Duitse literatuur de beschouwingen van $K$. Schmidt, Gesellschaftsrecht, 2 Auf., Köln 1991, blz. 52 en 58, omtrent Verbandszweck en Geschäfsgrundlage.

9. Hierover uitwoeriger onder $\$ 4,2$.

10. Deze term, die in het Nederlandse vennootschapsrecht door Van Schilfgaarde (1992), nr. 1, is ingeburgerd, is afkomstig van het Kelseniaanse rechtspositivisme (H. Kelsen, Allgemeine Staatslehre, Berlin 1925, blz. 66 e.v.). Opmerking verdient overigens het feit dat in Kelsen's theorie ook overeenkomsten als Teilrechtsordnungen zijn te beschouwen en dat Kelsen op dit punt geen onderscheid makt tussen de verschillende associatievormen. Vgl. hierover Flume (1983), blz. 22. Ja, zelfs de natuurlijke persoon is voor Kelsen niet anders dan een deelrechtsorde: "Denn gegenüber dem Gesamtsystem der Rechtsnormen, der totalen Rechtsordnung, stellt die physische Person ein mehr oder weiniger willkürlich abgegrenztes Teilsystem, eine

(Wordt vervolgd...) 
tis, waarin de autonomie van het individu de vennootschappelijke verhoudingen in belangrijke mate bepaalt. De rechtsgenoten (oprichters en aandeelhouders) zijn vrij om de rechtspersoon in te richten zoals het hen goed dunkt. Dat deze vrijheid niet onbeperkt is, dat zij zelfs op sommige punten (bijv. in de regeling van het toezicht bij structuurvennootschappen) belangrijke beperkingen kent, betekent niet dat zij non-existent is. Dezelfde principiële vrijheid die aan contractspartijen toekomt om bestaan en inhoud van hun rechtsverhouding autonoom te bepalen, komt de rechtsgenoten toe terzake van de op- en inrichting van de rechtspersonen van het privaatrecht. Daarom kunnen zij ook, binnen de wettelijke grenzen, aan de toezichthoudende taak van de rvc naar eigen inzicht vorm geven. Voor zich spreekt dat deze taak een zekere inhoud moet hebben en dat de statuten aan de rvc geen bevoegdheden mogen ontzeggen die noodzakelijk zijn om een behoorlijk toezicht uit te oefenen. ${ }^{12}$

Bij een NV en BV kan worden uitgegaan van het feit dat de rechtspersoon in het leven is geroepen om een onderneming te exploiteren. Voorts kan worden aangenomen dat het uiteindelijke ondernemingsdoel de rentabiliteit op lange termijn is. ${ }^{13} \mathrm{Ik}$ zou dan ook willen stellen dat de toezichthoudende taak van de rvc bij een vennootschap die tot doel heeft een onderneming te exploiteren, gericht dient te zijn op het bereiken van deze rentabiliteit. ${ }^{14}$ Dit doel is niet in die zin overheersend dat bij realisatie

\section{0.(...vervolg)}

keineswegs absolut, sondern nur relativ selbständige Teil-Rechtsordnung dar" (blz. 64), "... die sogennante "physische" Person muß in demselben Sinne und in demselben Maße juristische Person sein, wie die bisher altein sogennante "juristische" Person selbst, wenn sie überhaupt als Rechts-Subjekt Objekt der Rechtserkenntnis sein soll" (blz. 63). Voorts dient het begrip deelrechtsorde in deze theorie "zuiver normatief" te worden verstaan. Op geen enkele manier kan het worden geidentificeerd met de sociale realiteit (institutie) die het begrip normeert. Vgl. H.J. Wolff (1933), blz. 64-65. Het is niet in te zien hoe Hauriou's institutionele leer -die ook door Van Schilfgaarde wordt aangehangen- te verzoenen is met Kelsen's reine Rechtslehre.

11. Uit de vorige noot moge blijken dat aan deze duiding geen rechtsgevolgen kunnen worden verbonden. Rechtens kan aan het nut van de kwalificatie zeker worden getwijfeld.

12. Zo zou bijv. het informatierecht van art. 141 niet aldus geclausuleerd kunnen worden dat voor het verkrijgen van die informatie de toestemming van enig vennootschapsorgaan vereist zou zijn.

13. Vgl. F. Rittner, Wirtschaftsrecht, Karlsruhe 1979, blz, 133. De uiteindelijke gerichtheid van de vennootschap op rentabiliteit is ten onzent door Maeijer gesignaleerd (1964), blz. 6.

14. Bij vennootschappen waarbij andere doelstellingen dan de rentabiliteit op lange termijn nagestreefd worden, zullen commissarissen zich dienen te richten naar het doel in kwestie. 
ervan rechten van derden mogen worden geschaad. De onderneming die door de vennootschap geëxploiteerd wordt is een organisatie waarbij mensen en produktiemiddelen betrokken zijn. Met name de belangen van de werknemers verdienen naar de huidige rechtsopvattingen bijzondere bescherming. In zoverre deze belangen rechtens relevant zijn, is het sociale beleid van de vennootschap een omstandigheid die het eigenlijke doel van de vennootschap medebepaalt. Voorts bestaan er tal van andere factoren die per vennootschap kunnen variëren, bijvoorbeeld de verhouding tot de regio, haar afhankelijkheid ten opzichte van een buitenlandse moeder, etc. Ook deze factoren kunnen van invloed zijn op het doel van de vennootschap en derhalve op de door commissarissen te vervullen taak. Op de betekenis van deze factoren zal ik hierna bij de bespreking van het begrip vennootschappelijk belang nader ingaan. Zonder afbreuk te doen aan de betekenis van alle genoemde factoren kan worden gesteld dat de toezichthoudende taak van de rvc bij een vennootschap die tot doel heeft de exploitatie van een onderneming, hoofdzakelijk bepaald wordt door de rentabiliteit van de onderneming. De resultaten van de onderneming zijn de eerste maatstaf voor de beoordeling van de taakvervulling door de rvc. ${ }^{15}$ Bij de taakvervulling van de rvc speelt dan ook een belangrijke rol alles wat een indicatie geeft van de economische positie van de onderneming. Hierbij dient met name aan de accountantscontrole te worden gedacht, maar ook aan het oordeel van financiers, etc.

Aan het wettelijk systeem ligt ten grondslag een scheiding tussen beleidsbepaling en beleidscontrole. Beleidsbepaling behoort tot de competentie van het bestuur. Beleidsbepaling houdt in het opstellen en realiseren van doelstellingen. De rvc heeft niet een initiërende maar een controlerende taak. ${ }^{16}$ Het beroep van sommige schrijvers op de taalkundige betekenis van de term "toezicht" is in zoverre gerechtvaardigd dat uit de aard der zaak volgt dat het toezicht een corrigerend, zo men wil, repressief karakter heeft. De toezichthoudende taak van commissarissen beperkt zich er toe te zorgen dat het beleid van het bestuur en de algemene gang van zaken binnen de vennootschap beantwoorden aan het vennootschappelijke doel.

Niet uitgesloten is dat tussen bestuur en rvc verschil van mening bestaat over het te voeren beleid. De vraag rijst dan welke instantie de ultieme zeggenschap heeft. Een eenduidig antwoord is mijns inziens niet te geven. Dat het bestuur een eigen verantwoordelijkheid draagt voor de

15. Omdat het vennootschappelijke doel evenzeer de taakvervulling van het bestuur normeert, is het in de tekst gestelde ook op dit orgaan van toepassing.

16. Hiertegen verzet zich niet dat de rve volgens art. 140 ook een adviserende taak heeft. Zie hierover het volgende nummer. 
leiding van de vennootschap wordt sedert het Forumbank-arrest $\mathrm{t}^{17}$ algemeen aanvaard. Ten gevolge van deze verantwoordelijkheid is het bestuur niet gebonden aan specifieke instructies van andere organen. Anderzijds zou men de toezichthoudende taak van de rvc van haar inhoud ontdoen indien dit orgaan niet in staat zou zijn onjuist beleid tegen te houden of te keren. Mij lijkt dat het antwoord op de gestelde vraag afhangt van de bevoegdheidsverdeling tussen beide organen. Hoe zwaarder de bevoegdheden zijn die wettelijk of statutair aan de rvc zijn toebedeeld, hoe eerder zal moeten worden aangenomen dat wet en statuten een zeker overwicht aan dit orgaan hebben willen toekennen. Zo kan in het algemeen worden gesteld dat bij vennootschappen waarvoor het volledige structuurregime geldt, bij verschil van inzicht de rvc in deze het laatste woord heeft, terwijl bij gewone vennootschappen de toezichthoudende taak aldus kan worden ingericht dat bij verschil van inzicht het oordeel van het bestuur prevaleert. $^{18}$

Onder omstandigheden is een directe ingreep van de rvc in het beleid van het bestuur niet uitgesloten. ${ }^{19}$ Hiertoe zal aanleiding kunnen bestaan wanneer de resultaten van de vennootschap onvoldoende worden geacht of, meer in het algemeen, wanneer het beleid van het bestuur niet voldoet aan de normen waaraan naar het oordeel van de rvc dit beleid dient te voldoen. Zulks impliceert dat de rvc een beeld behoort te hebben van het eigenlijke vennootschapsdoel en van hetgeen op ieder moment juist beleid dient te zijn. ${ }^{20}$

Daar het beleid van de vennootschap geraakt wordt door het ingrijpen van de rvc, kan men zich afvragen of zulks niet als het verrichten van daden van bestuur moet worden beschouwd (art. 151 lid 1). Deze problematiek doet zich hoofdzakelijk voor bij de goedkeuring van bestuursbesluiten. Het kan niet worden ontkend dat de toezichthoudende activiteit van de rvc invloed heeft op het vennootschappelijk beleid, in zoverre dit beleid anders is naar gelang de rvc bijvoorbeeld een bestuursbesluit al of niet goedkeurt. Het ware echter niet juist deze beïnvloeding van het bestuursbeleid als bestuurshandeling in de zin van art. 151 te kwalificeren. Wanneer commissarissen het goedkeuringsrecht uitoefenen of wanneer zij anderszins in de vervulling van de toezichthoudende taak het vennootschappelijk beleid beinvloeden, verrichten zij handelingen die in het wettelijk systeem een

17. HR 21 januari 1955 , NJ $1959,43$.

18. Omdat, zoals later zal blijken, de vennootschap dienstig is aan de rechtmatige belangen van de aandeelhouders, is de stem van de algemene vergadering in laatste instantie beslissend.

19. In deze zin ook Glasz (1992), blz. 18.

20. In deze zin ook Van de Vijver (1989), blz. 18. Zie hierover voorts Martens, Kölner Kommentar, §111, Rdn. 34-35. 
toezichthouder behoort te verrichten en dragen zij de overeenkomstige verantwoordelijkheid. Zulks is ook met zoveel woorden in wet bepaald (art. 151 lid 2). ${ }^{21}$

De rvc is een orgaan van de vennootschap. De raad oefent zijn toezichthoudende taak uit jegens de rechtspersoon. Niet geheel correct lijkt mij het in de literatuur niet zelden gehuldigd standpunt dat de rvc, of zijn leden, verantwoording schuldig zijn an de ava, aan de or of in het algemeen aan alle bij de vennootschap betrokken personen. Paradigmatisch is in dit verband het standpunt van Maeijer. ${ }^{22}$ "Uit deze bepaling [art. 161 lid 2, JMBF] blijkt dat de commissaris bij de grote vennootschap over zijn doen en laten verantwoording schuldig is aan alle bij de vennootschap betrokken personen, ook jegens de raad van commissarissen waarvan hij zèlf deel uitmaakt." Maeijer beperkt zijn stelling weliswaar tot structuurvennootschappen en baseert zich met name op het feit dat het ontslagverzoek mede door de or kan worden ingesteld, doch omdat de taakstelling van de rvc gelijk is voor structuur- en niet-structuur vennootschappen ${ }^{23}$ is het, naar het mij voorkomt, niet mogelijk op dit punt onderscheid te maken al naar gelang het rechtsregime waaraan de vennootschap is onderworpen. Voorts kan uit art. 161 niet worden geconcludeerd dat commissarissen enige verantwoording schuldig zouden zijn aan de in dat artikel genoemde instanties. De strekking van het artikel beperkt zich mijns inziens tot het ontvankelijk verklaren van zekere personen tot het instellen van het ontslagverzoek. De ontslaggrond is echter, voor zover hier van belang, de verwaarlozing van de commissariële taak. Ontslag is dan ook slechts mogelijk indien de commissaris zijn verplichtingen jegens de rechtspersoon heeft geschonden. De ondernemingsraad en andere instanties kunnen belang hebben bij een correcte taakvervulling door commissarissen. Op grond van dat belang kunnen zij door de wet ontvankelijk worden verklaard tot het instellen van een vordering tot het beëindigen van de rechtsverhouding tussen vennootschap en commissarissen. Maar zulks brengt niet mede dat op commissarissen krachtens het ambt dat zij bekleden enige rechtsplicht jegens bedoelde instanties rust. ${ }^{24}$

21. Evenzo Löwensteyn (1959), blz. 199. Volgens Handboek, nr. 275, vindt het gebruik van de term 'medebestuur' zijn rechtvaardiging in de omstandigheid "dat er normaliter een zekere eenheid is tussen bestuur en raad van commissarissen." Anderzijds wordt opgemerkt dat commissarissen daarmee geen bestuurlijke taak vervullen. De term medebestuur is dan mijns inziens rechtens zonder betekenis.

22. (1972), blz. 38-39.

23. Zie onder $\$ 1$,III.

24. In dezelfde zin waarschijnlijk ook Van der Grinten, De NV 61 (1983), blz. 157, in een reactie op een artikel waarin gepleit wordt voor een publieke verantwoording

(Wordt vervolgd...) 
II Toezicht op het beleid van het bestuur en op de algemene gang van zaken in de vennootschap en de met haar verbonden onderneming

Onderwerp van de toezichthoudende werkzaamheden van de rvc is volgens art. 140 lid 2 "het beleid van het bestuur en de algemene gang van zaken in de vennootschap en de met haar verbonden onderneming." Over deze bepaling merkt Löwensteyn ${ }^{25}$ op: "Men mag zich afvragen of het beleid van het bestuur zich niet evenzeer uitstrekt tot de 'algemene gang van zaken in de vennootschap', terwijl de gang van zaken in de onderneming van de vennootschap daaronder stellig is begrepen, zodat het niet geheel ongerechtvaardigd is te zeggen, dat de wetgever zich hier heeft bezondigd an fraseologie." Voor wat betreft de vermelding van de onderneming naast de vennootschap lijkt mij zulks ook een fraseologische exercitie. ${ }^{26}$ Op een ander punt kan de wettekst echter redelijke zin hebben. Immers, het is juist dat het beleid van het bestuur zich uitstrekt tot de algemene gang van zaken in de vennootschap, maar dat wil niet zeggen dat elk besluit of elke handeling binnen de vennootschap die de algemene gang van zaken raakt, van het bestuur afkomstig is. Men denke aan de uitgifte van een belangrijk pakket aandelen door de ava. Krachtens art. 140 is de rvc naar mijn mening gehouden om zich te buigen over de merites van de uitgifte. De toezichthoudende taak van de rvc beperkt zich volgens genoemd artikel niet tot handelingen van het bestuur maar omvat ook handelingen van andere organen die voor de vennootschap van belang kunnen zijn. Voorts kan het beleid van de vennootschap feitelijk door anderen dan bestuurders worden bepaald. Ook tot deze feitelijke bestuurders strekt de commissariële controle zich uit. De toezichthoudende taak van de rvc, met andere woorden, is niet orgaan- maar zakelijk bepaald. ${ }^{27}$

Het voorgaande sluit niet uit dat onder normale omstandigheden het

\section{4.(...vervolg)}

van de raden van commissarissen van structuurvennootschappen (Van Hoorn/Dekker, De NV 61 (1983), blz. 145 e.v.). Van der Grinten stelt: "De Raad van Commissarissen is niet een buitenstaande instantie die toezicht uitoefent op het doen en laten van het bestuur van een vennootschap. Hij is een vennootschapsorgaan, dat in de interne vennootschapsorganisatie een zeker toezicht heeft op het besturen van de vennootschap" (curs. in het origineel).

25. Rechtspersonen, art. 140, aant. 4.

26. Over de zin van de vermelding vergelijkt de MvT, Macijer, Wetsgeschiedenis, IXfArt. 50 (II)-2.

27. Deze kwestie is in Duitsland omstreden omdat $\$ 111 \mathrm{AktG}$ de toezichthoudende taak van de Aufsichtsrat beperkt tot de Geschaftsfihrung. Zie daarover $K$. Duden, Überwachung: wen oder was?, FS Fischer, Berlin 1979, blz. 95 e.v. (toezicht is zakelijk bepaald) en Lutter/Krieger (1989), blz. 31 e.v. (toezicht is orgaan-bepaald). 
beleid van de vennootschap door het bestuursorgaan bepaald wordt. Toezicht op de bestuursgestie is dan ook tevens toezicht op het beleid van de vennootschap. De gezamenlijke -niet gelijke- verantwoordelijkheid van bestuur en rvc voor het vennootschappelijk beleid betekent dat in het wettelijk systeem een zeker samenspel tussen beide organen bestaat. ${ }^{28}$ De rvc dient zijn goedkeuring te verlenen aan de algemene lijnen van het beleid zoals dit door het bestuur is uitgestippeld. Naar buiten toe zullen bestuur en rvc veelal als eenheid, als de leidinggevende organen van de vennootschap optreden. De rvc behoort dit samenspel slechts te doorbreken wanneer hij redenen heeft om te twijfelen aan de juistheid van het door het bestuur gevoerde beleid.

Bij dit samenspel komt aan informatie een belangrijke plaats toe. De rvc is bij zijn controlerende taak in zoverre op het bestuur aangewezen dat volgens art. 141 het bestuur aan de rvc de voor de toezichthoudende taak noodzakelijke informatie dient te verschaffen. Zonder deugdelijke informatieverschaffing aan de rvc door het bestuur is behoorlijke controle niet mogelijk. ${ }^{29}$ Behoorlijke controle begint bij het genoegzaam geïnformeerd zijn over de aangelegenheden die de vennootschap betreffen. Anderzijds heeft de controlerende taak van commissarissen in zoverre een van het bestuur onafhankelijk karakter dat zij de voor de uitoefening van hun functie noodzakelijke gegevens desnoods buiten het bestuur om kunnen verkrijgen. ${ }^{30}$

In tegenstelling tot het Duitse AktG $(\S 90)$, geeft het BW geen gedetailleerde opsomming van onderwerpen waarover het bestuur de rvc periodiek dient te informeren. De onderwerpen van het commissariële toezicht worden niet expressis verbis in de wet genoemd. Doch, omdat de rvc verantwoordelijk is voor het totale beleid van de vennootschap, moet worden aangenomen dat het toezicht niet beperkt is tot een bepaald onderdeel van het beleid. Dit betekent niet dat de totale activiteit van het bestuur gecontroleerd dient te worden. Slechts die zaken die het vennootschappelijk belang in belangrijke mate raken dienen door de rvc te worden gecontroleerd.

De wet zwijgt overigens niet geheel over het onderwerp van het commissariële toezicht. Art. 164 geeft een opsomming van bestuursbesluiten waarvoor bij structuurvennootschappen instemming van de rvc

28. Zo ook Handhoek, nrs. 274-275.

29. Terecht schrijft Van der Burg (1983), blz. 329: "Toezicht veronderstelt informatie."

30. Vgl. Rb. Breda 1 mei 1990, NJ 1990, 740: "Het moge zo zjjn geweest dat in beginsel de raad van commissarissen angewezen was op de informatie van de directie, doch gegeven de omstandigheden van het geval zoals hiervoor omschreven, was het onverantwoord om nog langer op de mededelingen van de directie af te gaan." 
vereist is. De enuntiatieve lijst van art. 164 kan ook als criterium gelden voor de rve van niet-structuurvennootschappen. Welke onderwerpen voorts tot de bevoegdheidssfeer van de commissarissen behoren is niet in abstracto te zeggen. ${ }^{31}$ Veel zal afhangen van de vennootschap in kwestie.

Voorzover de controlerende taak van commissarissen betrekking heeft op het beleid van de vennootschap kunnen de effecten van het toezicht zich tot andere rechtspersonen uitstrekken. Dit is met name het geval in concernverhoudingen. Zoals de leidinggevende taak van het bestuur van de moedervennootschap zich uitstrekt tot de dochters, zo omvat ook het commissariële toezicht het beleid op dochter niveau. De wet bepaalt in art. 164 lid 1 sub $d, e, j$ en $k$ dat de instemming van de rvc vereist is voor bepaalde transacties die door de vennootschap zelf of door een van haar afhankelijke maatschappij worden aangegaan. Wanneer het bestuur van de vennootschap die aan het hoofd van de groep staat, voornemens is een besluit in de zin van art. 164 te nemen, vindt de controle van de rvc plaats door middel van goedkeuring van dat besluit. Voor zover een dergelijke transactie op een lager niveau plaatsvindt zonder dat het bestuur van de moeder daarbij is betrokken, is goedkeuring als bedoeld in art. 164 uit de aard der zaak niet mogelijk. Indien de transactie het belang van de moeder raakt, kan de rvc niettemin gehouden zijn het bestuur van de moedervennootschap te vragen de nodige instructies aan de dochter te geven ${ }^{32}$

\section{Collegiale uitoefening van het toezicht}

De term 'raad van commissarissen' werd door de Structuurwet in de wetgeving geintroduceerd. Zowel het Wetboek van Koophandel als de Wet van 1928 spraken slechts van 'commissarissen'. Met de nieuwe term wilde de wetgever tot uitdrukking brengen dat de commissariële taak en bevoegdheden toekomen aan het college van commissarissen, als orgaan van de vennootschap, en niet aan de individuele commissarissen. ${ }^{33}$ Overigens kon dit standpunt reeds vó́r inwerkingtreding van de Structuurwet als geldend recht worden beschouwd. ${ }^{34}$

Dat de toezichthoudende taak aan de rvc als college is toebedeeld

31. Concreter op dit punt W.C.L. Van der Grinten, De bevoegdheidssfeer van de commissaris, De NV 26 (1948-49), blz. 113 e.v.

32. Deze controlerende taak van de moeder-rve in groepsverband wordt door Uniken Venema (1984), blz. 54 e.v. gerelativeerd. Zie hierna $\$ 1$, IV en $\S 9$.

33. Maeijer, Wetsgeschiedenis, IXf - Art. II-1.

34. Zie voor allen Van der Grinten, De NV 26 (1948-49), blz. 116 en Handboek, Gde druk, 1962, nr. 274. 
betekent dat zij moet worden uitgeoefend door het orgaan als geheel. De rechten en plichten welke inherent zijn aan de taak, komen dan ook in beginsel toe aan het orgaan en niet aan de individuele leden.

Organisatie en besluitvorming van de rvc worden in de wet niet nader geregeld. Deze regeling zal moeten worden gegeven in de statuten of in het ordereglement van de raad. Wanneer voor een concrete situatie geen voorziening bestaat, dienen algemene rechtsbeginselen te worden toegepast.

Tussen structuur- en niet-structuurvennootschappen bestaat een wezenlijk verschil voor wat betreft de rechtspositie van de rvc. Bij eerstgenoemde vennootschappen beslist de raad zelf over de bezetting van de commissarisposten. Daarentegen staan de commissariële ambten bij gewone vennootschappen ter dispositie van de algemene vergadering. ${ }^{35}$ Hoewel in beide gevallen de rvc onafhankelijk is van de ava, in die zin dat hij zelfstandig beslist over de uitoefening van zijn bevoegdheden en daarvoor een eigen verantwoordelijkheid draagt, is de onafhankelijkheid bij gewone vennootschappen in zoverre relatief dat de benoemings- en ontslagbevoegdheid van de ava de mogelijkheid inhoudt over de samenstelling van de rvc, en daardoor in feite over zijn beleid, te beschikken. Dit dwingendrechtelijke verschil in rechtspositie is van invloed op de zeggenschap van de algemene vergadering inzake de organisatie van de rvc. Bij gewone vennootschappen kan worden aangenomen dat de ava statutair of door middel van een reglement de organisatie en besluitvorming van de raad kan regelen. Bij structuurvennootschappen is zulks naar mijn mening niet mogelijk omdat alsdan een vreemd orgaan beschikt over aangelegenheden die krachtens dwingend recht aan de rvc toekomen. Hiermee is niet gezegd dat bij gewone vennootschappen de ava over elke aangelegenheid van de rvc kan beslissen, terwijl bij structuurvennootschappen de raad geheel autonoom zou zijn. Zo is bijvoorbeeld de algemene vergadering bij laatstgenoemde vennootschappen bevoegd om het aantal leden van de raad naar eigen inzicht te bepalen, maar is zij bij een gewone vennootschap niet bevoegd om een ordemaatregel te treffen in een vergadering van de rvc.

Tegen het collegiale karakter van de taak verzet zich niet dat de uitoefening van de taak onder de leden van het orgaan wordt verdeeld. De wet lijkt taakverdeling in art. 9 implicite te aanvaarden, en juist in het kader van de aansprakelijkheid voor de collegiale taakuitoefening is in de literatuur

35. Op grond van art. 143 kunnen de statuten aan een andere instantie dan de ava de benoemingshevoegdheid toekennen voor ten hoogste een derde van de posten. In zoverre deze bevoegdheid op de statuten berust, is zij onderworpen aan de zeggenschap van de algemene vergadering. 
aandacht besteed aan de betekenis van de collectieve taakvervulling. ${ }^{36}$

Taakverdeling kan berusten op statutaire bepalingen, op een reglement of op een ad hoc besluit. In deze gevallen zal het in de regel niet bezwaarlijk zijn vast te stellen welke taak aan ieder lid van of commissie uit de raad is toegewezen. Mogelijkerwijs worden bij de taakverdeling ook concrete bevoegdheden toebedeeld. Is dat niet het geval, dan zal dienen te worden aangenomen dat aan betrokkene tenminste die bevoegdheden toekomen die nodig zijn om de hem toevertrouwde taak te vervullen.

Meer moeilijkheden kunnen zich voordoen indien de taakverdeling niet op een bevoegdelijk genomen besluit berust, maar wel de facto door de leden van het orgaan in acht wordt genomen. Kan onder deze omstandigheden van een geldige takkverdeling worden gesproken? Naar mijn mening wel. Het gedrag van de orgaanleden kan mijns inziens duiden op de wil van betrokkenen om een zodanige taakverdeling tot stand te brengen. Op dezelfde wijze als zij krachtens een uitdrukkelijk besluit een reglement kunnen vaststellen, kan onder omstandigheden uit de facta concludentia eenzelfde wil tot taakverdeling worden afgeleid.

Zoals gezegd houdt toebedeling van een (deel)taak een zekere delegatie van bevoegdheid in. Delegatie kan geschieden aan een bepaalde persoon (bijv. bij benoeming van een gedelegeerde commissaris), of aan een groep. In dit laatste geval zal de betrokken commissie, voor zover bij haar instelling niet anders is bepaald, als college functioneren en krachtens meerderheid van stemmen beslissen. In dit college kunnen slechts leden van de rvc worden benoemd, omdat het in strijd met de wet zou zijn dat bevoegdheden die aan een wettelijk orgaan worden toebedeeld, door anderen dan commissarissen worden uitgeoefend. Wanneer een derde zitting zou nemen in een dergelijk college en, in het algemeen, wanneer commissariële bevoegdheden door anderen dan commissarissen zouden worden uitgeoefend, zouden de externe handelingen die verricht worden op grond van de besluiten van het college voor de vennootschap bindend zijn indien de vennootschap rechtsgeldig wordt vertegenwoordigd. De rvo zou zich echter aan onbehoorlijke taakvervulling schuldig maken.

Van de delegatie moet worden onderscheiden de machtiging aan een of meer leden om bepaalde bevoegdheden van de raad uit te oefenen. Terwijl delegatie op toebedeling van bevoegdheid voor een onbepaald aantal handelingen wijst, houdt machtiging toebedeling van bevoegdheid voor eén of meer concrete handelingen in.

Uitoefening van de bevoegdheden van mede-commissarissen kan mijns inziens tenslotte krachtens volmacht geschieden. Statuten en reglement

36. Uitvoeriger over dit punt onder $\$ 17$,II,c. 
kunnen aan de volmacht nadere eisen stellen. ${ }^{37}$ Omdat de benoeming tot commissaris, en dus ook de taakvervulling, een persoonlijk karakter heeft, zou het ongeoorloofd zijn dat een commissaris zich blijvend door een ander zou laten vertegenwoordigen.

Terwijl delegatie, machtiging en volmacht slechts aan leden van de rvc kunnen plaatsvinden, kunnen niet-commissarissen wel worden gemachtigd tot de uitvoering van de besluiten van de rvc of om als bode een verklaring van een commissaris over te brengen. Onder omstandigheden kan er twijfel bestaan of een bepaalde handeling heeft te gelden als de uitoefening van een commissariële bevoegdheid, zodat die slechts door commissarissen kan worden verricht, of als uitvoering van een bevoegdelijk genomen besluit. Men denke aan de goedkeuring door de rvc van een transactie waaromtrent in algemene lijnen overeenstemming bestaat, doch die nog 'uitonderhandeld' moet worden. Of een niet-commissaris (bijv. een bestuurder) gemachtigd kan worden om zelfstandig de onderhandelingen tot het einde voort te zetten en de 'instemming' van de rvc aan de wederpartij over te brengen, zal mijns inziens van de omstandigheden afhankelijk zijn: is er nog ruimte voor een zelfstandig oordeel van de niet-commissaris; in hoeverre is het mogelijk na afloop van de onderhandelingen met de rvc te overleggen, etc. ${ }^{38}$

Delegatie van een deel van de taak brengt geen wezenlijke verandering in de functionele positie van de raad als orgaan, noch van de individuele leden jegens de vennootschap. Door de taakverdeling worden commissarissen niet ontslagen van hun recht en plicht tot controle van het bestuursorgaan. Taakverdeling kan tot stand worden gebracht ten einde een betere vervulling van de taak door het orgaan te bereiken. Maar zij kan niet zover gaan dat daardoor het orgaan of individuele commissarissen verstoken blijven van het recht en de plicht om het toezicht te houden waartoe zij gehouden zijn. Met name blijven commissarissen te allen tijde bevoegd om hun informatierecht krachtens art. 141 geldend te maken.

37. Anders dan Sanders/Westbrock (1991), blz. 177, schrijven, lijkt mij niet nodig dat de statuten in de mogelijkheid van volmachtverlening voorzien. Deze bevoegdheid ligt in het ambt besloten. Het persoonlijk karakter van het commissariaat verzet zich er niet tegen dat onder bepaalde onstandigheden de commissariële bevoegdheden door een andere commissaris worden uitgeofend.

38. Hier raken wij mede aun de problematiek van het onderhandelen onder voorbehoud van goedkeuring. Zie hierover H.J. de Kluiver, Onderhandelen en privaatrecht, Deventer 1992, nrs. 22, 309 en 343. 


\section{Toezichthoudende organen}

Art. 140 geldt voor elke vennootschap waarin een rvc is ingesteld. Voor structuurvennootschappen is de instelling van een rvc verplicht (art. 158). Aan de structuur-rvc komen voorts, al naar gelang het wettelijke regime waaraan de vennootschap is onderworpen, dwingendrechtelijk enkele bevoegdheden toe die niet, althans niet dwingend, aan de rvc van gewone vennootschappen toekomen. Dit zijn de bevoegdheden vermeld in de artt. 158, 162, 163 en 164. Het verschil in bevoegdheden zou kunnen leiden tot de gedachte dat er sprake is van verschillende organen en dat art. 140 niet in gelijke mate van toepassing is op rvc's van structuur en niet-structuurvennootschappen. Dit is mijns inziens in zoverre juist dat de uitoefening van de commissariële taak bepaald wordt door de bevoegdheden die aan de rvc toekomen ${ }^{39}$ Aldus bezien is de toezichthoudende taak van een structuur-rvc in het algemeen een zwaardere dan die van een gewone rvc. Maar de taakstelling is in beide gevallen dezelfde nu art. 140 op de rvc's van zowel structuur- als gewone vennootschappen van toepassing is. ${ }^{40} \mathrm{Dit}$ is de bedoeling van de wetgever. ${ }^{41}$ Ook de Departementale Richtlijnen 1986 (§6) maken wat de commissariële taak betreft geen onderscheid tussen de twee soorten vennootschappen.

Een enigszins andere vraag is of de wet de mogelijkheid biedt om een toezichthoudend orgaan in het leven te roepen waarop de artt. 140 e.v. niet van toepassing zijn. De problematiek is met name van belang voor nietstructuurvennootschappen, omdat in het geval van structuurvennootschappen moet worden uitgegaan -gezien de strekking van de Structuurwet- van een hoofdzakelijk dwingende regeling van het toezicht. In de praktijk heeft de zojuist gestelde vraag zich voorgedaan naar aanleiding van een statutenwijziging van NV Philips Gloeilampenfabrieken. ${ }^{42}$

39. Zie hierover verderop in de tekst $\S 5$ en $\S 17,1, a$.

40. Dit geldt overigens ook voor de andere bepalingen inzake het commissariaat (artt. $141 \mathrm{t} / \mathrm{m} \mathrm{152}$ ), behalve voor wat betreft de artikelen inzake de wijze van benoeming, ontslag en schorsing (artt. 143 en 144).

41. Maeijer, Wetsgeschiedenis, IXf- Art. II-1: "Deze bepalingen [artt. 50 e.v. WvK, de huidige artt. 140 e.v. Boek 2 BW, JMBF] hebben niet slechts betrekking op het commissariaat bij grote vennootschappen maar betreffen met name de taak, de bevoegdheden en de voorzieningen ten aanzien van de benoemingsprocedure in het algemeen."

42. Daarover Van der Grinten, De NV 61 (1983), blz. 157 e.v., De NV 62 (1984), blz. 108-109 (ontkennend) en Uniken Venema, De NV 62 (1984), p. 49 e.v. en 100 e.v. (hevestigend). Voor zover niet anders aangegeven zal in het hierna volgende, wanneer genoemde schrijvers worden aangehaald, naar deze vindplaatsen worden verwezen. 
Uitgangspunt bij de beantwoording van de vraag dient mijns inziens het dwingend karakter van het vennootschapsrecht te zijn. Art. 25 staat afwijkingen van de wettelijke regeling toe voor zover zulks uit de wet blijkt. Andere organen dan die welke in de wet zijn voorzien, zullen derhalve in beginsel slechts kunnen worden gecreëerd wanneer uit de wet blijkt dat zij toelaatbaar zijn. In het algemeen zou ik dan ook de vraag of een toezichthoudend orgaan dat niet een rvc is in de zin van artt. 140 e.v., bestaanbaar is, ontkennend willen beantwoorden. Bij dit standpunt passen echter de volgende opmerkingen.

In de eerste plaats dient de betekenis van art. 25 in zoverre te worden gerelativeerd dat dit artikel niet een concreet criterium geeft aan de hand waarvan zonder twijfel beoordeeld kan worden of een contractuele of statutaire bepaling in strijd met de wet is. Het lijkt mij dat voor zover het nieuwe orgaan in het wettelijk systeem past, tegen een dergelijk orgaan geen bezwaar bestaat. In zoverre is de stelling van Uniken Venema (blz. 52) dat in ons recht geen 'gesloten systeem' geldt voor wat betreft de creatie van organen in de rechtspersonen van het privaatrecht, juist. Echter, omdat de structuur van de vennootschap, dat wil i.c. zeggen: de toebedeling van taken en bevoegdheden aan concrete organen, door de wet dwingend wordt geregeld, moet worden aangenomen dat de rechtsgenoten de macht ontberen om het wettelijk systeem te 'vervolmaken', ${ }^{43}$ Creatie van facultatieve organen zal veelal een beperkte strekking hebben, namelijk de taakvervulling van de wettelijke organen te laten plaatsvinden naar het inzicht van de rechtsgenoten. Zo zal bijvoorbeeld een gedelegeerde commissaris kunnen worden benoemd die met het dagelijks toezicht is belast. Voor zover deze facultatieve organen belast zijn met de uitoefening van vennootschappelijke bevoegdheden, zijn zij onderworpen aan de beslissingsmacht van de wettelijke organen.

Vervolgens rijst de vraag in hoeverre de wettelijke toebedeling van een taak aan een bepaald orgaan in ons recht op dwingende wijze is geregeld. Meer in concreto dient te worden nagegaan of de toezichthoudende taak bij een niet- structuurvennootschap aan een ander orgaan dan de rvc kan worden toevertrouwd. Van der Grinten acht dit kennelijk niet mogelijk op

43. Vgl. Flume (1983), blz. 380. Illustratief in dit verband is de mening van Van der Burg (1990), blz. 65-66, die schrijft dat een bepaalde overeenkomst tussen een $\mathrm{nv}$ en haar aandeelhouders, waarbij aan de aandeelhouders een "beleidsadviserende stem' wordt gegeven, "een versterking van de aandeelhouderspositie ten opzichte van de nv inhoudt." Afgezien van het feit dat de bewuste 'beleidsadviserende stem' aan de aandeelhouders niet hoeft te worden gegeven -in werkelijkheid is deze stem gebaseerd op een statutaire bepaling en ontstaat dus krachtens wilsbeschikking van de aandeelhouders-, kunnen de aandeelhouders noch de vennootschap "de aandeelhouderspositie" versterken. Deze positie wordt door de rechtsorde bepaald 


\section{TOEZICHTHOUDENDE ORGANEN}

grond van zijn stelling ${ }^{44}$ : het houden van toezicht doet de commissaris commissaris zijn. Impliciet is dit ook de mening van Uniken Venema wanneer hij stelt dat "door een niet-structuurvennootschap desgewenst andere toezichthoudende en/of adviserende organen kunnen worden ingesteld, dan een RvC. De 'andersoortigheid' moet dan tot uiting komen in de toepasselijke statutaire taakomschrijving, in die zin dat deze zich dient te onderscheiden van de wettelijke taakomschrijving voor RvC's" (blz. 52). Hieruit volgt dat wanneer het 'statutaire toezicht' overeenkomt met het wettelijk toezicht, het orgaan dat met die taak belast is als een rvc zal dienen te worden aangemerkt. Uiteraard moet dan worden aangegeven in hoeverre er een statutair toezicht bestaanbaar is dat niet overeenkomt met het wettelijk toezicht. Volgens Uniken Venema is dit mogelijk omdat art. 140 niet een uitputtende regeling bevat van de toezichtsmogelijkheden die zich in de vennootschapspraktijk kunnen voordoen. Zich beperkend tot het geval van een internationale holdingvennootschap, stelt deze schrijver: "In art. 2:140 (2) BW wordt geen rekening gehouden met de mogelijkheid, dat aan een toezichthoudend orgaan een toezichtsverantwoordelijkheid kan worden opgedragen met betrekking tot een 'groep van vennootschappen' een 'concern'- in haar geheel" (blz. 56). Als argument voor zijn standpunt voert Uniken Venema aan dat "deze thans in art. 2:140(2) BW neergelegde takomschrijving ontstond (...) in een tijd, waarin de aandacht van degenen die aan de totstandkoming van deze formule hebben bijgedragen, niet was gericht op de concernproblematiek" (t.a.p.). Naar ik meen is noch de stelling noch de daarvoor aangedragen argumentatie juist. Dat de wetgever van de Structuurwet, waarbij art. 140 in onze wetgeving werd ingevoerd, wel degelijk oog had voor de concernrechtelijke problematiek, en in het bijzonder voor die van de internationale holding, blijkt reeds uit het feit dat voor dit soort situaties een uitdrukkelijke vrijstelling van het structuurregime werd voorzien (art. $52 \mathrm{c}$ lid 3, sub b WvK; het huidige art. 153 lid 3 , sub b). Ook specifiek met de toezichthoudende taak in groepsverhoudingen, en wel met de in art. 140 genoemde taak, hield de wetgever rekening, waar in art. $52 \mathrm{n}$ lid 2 (het huidige art. 164) de goedkeuring van de rvc van de moedervennootschap werd geëist voor bepaalde transacties op dochterniveau. En ook wanneer in de parlementaire stukken wordt opgemerkt: "onder de concerns vragen die met een overwegend internationaal karakter de bijzondere aandacht", blijkt dat de wetgever zich bewust was van de verhoudingen in kwestie. ${ }^{45}$ Dat beide genoemde voorzieningen slechts op structuurvennootschappen van toepassing zijn is hier naar ik meen niet

44. Handboek, nr. 273.

45. Zie voorts de uitvoerige uiteenzettingen over het onderwerp bij Maeijer, Wetsgeschiedenis, IXf - Art.III - 4. 
relevant, omdat het in deze gaat om het beeld dat de wetgever, bij de totstandkoming van de Structuurwet, van het commissariële toezicht had, met name in concernverhoudingen. Daarbij speelt in de visie van de wetgever de aard van de betrokken vennootschap geen rol omdat, zoals reeds boven betoogd is, de strekking van de wet is dat het commissariële toezicht van art. 140 op alle vennootschapsvormen wordt toegepast.

Belangrijker dan de bezwaren tegen de door Uniken Venema aangedragen argumentatie is de mijns inziens incorrecte interpretatie van de wettelijke regeling. Genoemde schrijver gebruikt de term toezicht niet als terminus technicus en gaat er vanuit dat bepaalde toezichtsvormen die zich in de praktijk kunnen voordoen, niet door de wetgever zijn voorzien en dus buiten het toepassingsbereik van de wet vallen. De wetgever behoeft echter niet alle concrete situaties aan te geven waarin het commissariële toezicht toepassing zal vinden. Voor zover niet anders blijkt, en hiervoor heb ik reeds betoogd dat zulks mijns inziens niet is gebleken, moet worden aangenomen dat de door de wetgever beoogde regeling toegepast dient te worden op alle situaties waarin een controlerend orgaan datgene doet wat de wet 'toezicht houden' noemt, d.i. het zorgen voor de verwezenlijking van het doel waarvoor de vennootschap is opgericht. De statutaire taakomschrijving is in zoverre niet van belang. ${ }^{46}$ Het komt an op de bevoegdheden die aan de toezichthoudende instanties zijn toegekend. Zijn deze zodanig dat zij de instantie in kwestie in staat stellen om te handelen als een rvc in de zin der wet, dan zijn zij gericht op het uitoefenen van de commissariële taak. Het orgaan in kwestie is dan een rvc. Evenzeer als de persoon of instantie die daden van bestuur verricht als bestuurder c.q. bestuur moet worden beschouwd (art. 151), dient de persoon die toezichthoudende bevoegdheden bezit als commissaris te worden angemerkt. Of het toezicht in een internationaal concern, in een eenpersoons-BV of in een 'andere' vennootschap plaatsvindt, is voor de toepasselijkheid van de wet niet van belang. Slechts de feitelijke controle zal naar alle waarschijnlijkheid anders zijn, al naar gelang de aard van de onderneming die door de vennootschap wordt geëxploiteerd.

Men zou tenslotte kunnen betogen, en naar het mij voorkomt ligt deze veronderstelling aan het betoog van Uniken Venema ten grondslag, dat de feitelijke verhoudingen in een internationale holding zodanig anders zijn dan in een kleine eenpersoons-bv, dat de door de wet gebruikte term 'toezicht' meerdere betekenissen heeft en dus verschillende rechtsregimes medebrengt. Maar dit is niet juist. Op dezelfde wijze als het rechtsregime

46. Daarom konden de Departementale Richtlijnen 1976 bepalen ( $\$ 35$ ): "Indien de statuten bepalen dat er een raad van commissarissen zal zijn, behoeven zij zijn taak, als omschreven in het tweede lid van artikel $140(25)$, Boek 2 van het Burgerlijk Wetboek, niet te omschrijven." 
van een bv die als internationale holding opereert in beginsel gelijk is aan dat van een eenpersoons-bv, is het door de rvc's van beide bv's uit te oefenen toezicht gelijk. Dat de toepassing van hetzelfde rechtsregime in de verschillende omstandigheden tot andere resultaten leidt, doet niet af aan de gelijkheid van de betrokken regimes. Overigens volgt uit Uniken Venema's betoog dat de leden van een raad van toezicht commissarissen zijn en dat de vergadering van dergelijke leden een raad van commissarissen is. ${ }^{47} \mathrm{Hij}$ stelt immers op blz. 105: "Met betrekking tot àlle leden van de RvT [Raad van Toezicht, JMBF] dient mijns inziens in beginsel dezelfde aansprakelijkheidsregeling te gelden, als in de wet is neergelegd met betrekking tot commissarissen." Inderdaad: voor elke toezichthouder, hoe ook genaamd, geldt eenzelfde aansprakelijkheidsregeling als in de wet voor commissarissen is neergelegd omdat zij dezelfde bevoegdheden uitoefenen, aan hetzelfde rechtsregime zijn onderworpen en dus rechtens als commissarissen dienen te worden aangeerkt. ${ }^{48} 49$

Aan Uniken Venema moet zonder meer worden toegegeven dat het functioneren van de rvc verschillend kan zijn al naar gelang de omstandigheden van de onderneming van de betrokken vennootschap. In de praktijk kan behoefte bestaan om deze verschillen in iure te honoreren. Voor zover deze behoeften legitiem zijn ${ }^{50}$, dient de wet met een zekere soepelheid te worden toegepast. Anderzijds moeten de mogelijkheden tot een soepele toepassing, gezien art. 25 en de wordingsgeschiedenis van de Structuurwet, niet worden overschat.

In het bestek van dit boek is het niet mogelijk in detail in te gaan op concrete varianten van toezichthoudende colleges. Ik zou nog, zij het kort,

47. Schrijver ontkent zulks uitdrukkelijk (blz. 110).

48. Dit is mijns inziens de betekenis van de Departementale Richtlijnen, wanneer zij bepalen (\$ 6): "Kennen de statuten aan een of meer personen de bevoegdheden toe die wettelijk aan de raad van commissarissen toekomen, dan moeten deze commissarissen worden genoemd. Er is dan een raad van commissarissen aan welk orgaan geen andere benaming mag worden gegeven." Behalve de laatste volzin, die op zich niets toevoegt aan de eerste, was de tekst van de Richtlijnen 1976 (\$ 35) vrijwel gelijkluidend. Inhoudelijk bestaat tussen beide versies geen verschil.

49. Zoals in de tekst, Van der Grinten in het naschrift op het artikel van Uniken Venema (t.a.p.) en Slagter, TVVS 1990, blz. 149-150. Aan de hand van een concreet voorval stelt laatstgenoemde schrijver mijns inziens terecht dat de hier hesproken 'raad van toezicht' niet alleen rechtens als een rve was aan te merken, maar dat hij zich de facto ook zo gedroeg.

50. Geen legitieme behoefte, althans zolang de wet het onderwerp dwingend regelt, is de wens van de kandidaat-commissaris om de volle verantwoordelijkheid van het commissariaat niet te dragen. Zie Van der Grinten, De NV 61 (1983), blz. 157. 
aandacht willen besteden aan de door Van Schilfgaarde ${ }^{51}$ geopperde mogelijkheid om een "gecombineerde vergadering" van bestuur en rvc in te stellen. Uitgaande van de door Van Schilfgaarde voorgestelde bepaling ${ }^{52}$, zou ik het volgende willen opmerken.

Het is niet duidelijk wat beoogd wordt met een dergelijke constructie. Indien beoogd wordt het bestuur ondergeschikt te maken aan de gecombineerde vergadering, zou ik willen stellen dat onderwerping aan de rvc reeds mogelijk is zonder dat er sprake hoeft te zijn van een zodanige vergadering. De in de constructie genoemde bevoegdheden kunnen immers ook aan de rvc worden toegekend. Het bestuur is dan in belangrijke mate aangewezen op de instemming van de rvc. Wellicht is de gecombineerde vergadering niet bedoeld om het bestuur aan enig toezicht te onderwerpen, doch om het bestuur, althans enkele zijner leden, zeggenschap te geven met betrekking tot de toezichthoudende taak. Door zitting te hebben in de gecombineerde vergadering en daarmee, naar ik aanneem, ook door het verkrijgen van stemrecht in de vergadering, zouden bestuurders in zekere zin hun eigen handelen kunnen controleren. Deze constellatie zou ik in strijd achten met de wettelijke scheiding van bestuur en toezicht. $\mathrm{Zij}$ lijkt mij daarom ongeoorloofd. Overigens bestaat tegen de toebedeling van bijvoorbeeld voorbereidende en uitvoerende taken aan de gecombineerde vergadering in beginsel geen bezwaar. Deze voorbereidende handelingen zullen zich veelal in de interne sfeer van de vennootschap afspelen. Het daaruit resulterend beleid dient echter beleid te zijn van het bestuursorgaan. Dat beleid dient vervolgens aan het onafhankelijk toezicht. van de rvc te worden onderworpen. Indien met betrekking tot de toezichthoudende taak aan de gecombineerde vergadering enige zeggenschap zou zijn toegekend, bijvoorbeeld door middel van een goedkeuringsrecht, lijkt mij de constructie alleen mogelijk voor zover de gecombineerde vergadering onderworpen zou zijn aan de beslissingsmacht van de rvc. De zin van de constructie wordt dan echter kwestieus.

51. Contractuele structurering van bestuur en toezicht, (1991), blz. 11 e.v.

52. T.a.p., blz. 12. Deze luidt:

(1) Het bestuur moet zich gedragen naar de aanwijzingen van de gecombineerde vergadering betreffende de algemene lijnen van het te voeren financiele, sociale, economische en personeelsbeleid.

(2) Het bestuur behoeft de goedkeuring voor alle besluiten waarvan de gecombineerde: vergadering tevoren heeft bepaald dat deze aan haar goedkeuring onderworpen zijn.

(3) In alle gevallen waarin binnen het bestuur verschil van inzicht bestaat beslist de gecombineerde vergadering. 


\section{$\S 2$. Advies}

De wet vermeldt als tweede taak van de rvc het geven van advies (art. 140 lid 2). Onder het vroegere recht werd in de literatuur ruime aandacht besteed aan de verhouding tussen toezicht en advies. Er bestond verschil van inzicht omtrent de taak van commissarissen, hoofdzakelijk omdat de wet de taak van dit orgaan niet expliciet regelde. ${ }^{53}$ Onder de huidige wet is de situatie in zoverre anders dat zowel het houden van toezicht als het geven van advies als taken van de rvc worden genoemd.

Gesteld is dat tussen toezicht en advies geen scherp onderscheid kan worden gemaakt. Toezicht houden impliceert in deze visie het adviseren over het beleid dat gecontroleerd wordt. ${ }^{54}$ Anderzijds worden beide taken door sommigen als tegenstrijdig beschouwd. ${ }^{55}$ Volgens deze laatste opvatting is het niet mogelijk toezicht te houden op het beleid dat in zekere zin gevolg is van eigen advies. Het geven van advies veronderstelt aan de ene kant een onafhankelijke positie van de adviseur jegens de geadviseerde en aan de andere kant een zekere vrijheid van deze laatste om het verstrekte advies al of niet te volgen. Beide omstandigheden zouden zich niet voordoen in een systeem waarin het bestuur onderworpen is aan de commissariële controle.

Ratione materiae kan mijns inziens inderdaad worden getwijfeld aan de zelfstandige betekenis van de adviserende taak van de rvc. De rvc adviseert over hetzelfde beleid dat hij dient te controleren. De adviserende taak dient in ons wettelijk systeem te worden verstaan tegen de achtergrond van de controlerende taak en van de wettelijke bevoegdheden van de rvc. De rvc is primair een controlerend college. Hij is door de wet met de nodige bevoegdheden toegerust om te bewerkstelligen dat het beleid van het bestuur beantwoordt aan het vennootschappelijk belang zoals dit door de rvc

53. Zie W.C.L. Van der Grinten, De miskende commissaris, De NV 30 (1952-53), blz. 41 e.v.; P.J. Verdam, Taak en verantwordelijkheid van de Commissaris, De NV 30 (1952-53), blz. 206 e.v.; Th.M. Scholten, De Commissarisfunctie, De NV 36 (1958-59), blz. 10 e.v.; G.H.A. Grosheide, Het Commissariat in de Naamloze Vennootschap, De NV 36 (1958-59), blz. 122 e.v.; G.H.A. Schut, De commissaris en zijn plats in de n.v., Publicaties van de NPM. Amsterdam 1962; H.J. Hellema, De functie van de commissaris in de naambze vennootschap. Serie Belastingconsulentendag no. 10, Amsterdam 1965.

54. Typerend voor deze visie is het in de Duitse literatuur algemeen verdedigd stani punt dat de $A$ ufsichtsrat een adviserende taak toekomt, nolk al wordt zulks niet met zoveel woorden in de wet bepaald. Vgl. Geßler, Komm. AktG, $\$ 111$, Rn. 36 en Lutter/Krieger (1989), blz. 38 e.v. Zulks is onk in Je jurisprudentie lattstelijk erkend. Vgl. BGHZ 114, 127.

55. Zie voor allen in de recente literatuur, Ophof, Slagter-bundel (1988), blz. 192 en Van de Vijver, Maris-bundel (1989), hlz. 212. 
verstaan wordt. De rvc is niet alleen bevoegd maar ook gehouden die maatregelen te nemen die hem geraden voorkomen om dit te bereiken. Uit de controlerende taak vloeit noodzakelijkerwijs voort dat de rvc zijn mening over het beleid meedeelt aan het bestuur. In zekere zin ligt in elke controlerende handeling advies besloten. Wanneer de rvc een bestuursbesluit goed- of afkeurt, wanneer commissarissen de jaarstukken (weigeren te) ondertekenen, etc. houdt zulks een oordeel in over het aan het besluit ten grondslag liggend beleid. Dit is naar mijn mening het advies dat de wet primair van de rvc verwacht. Het is 'repressief' advies, in dier voege dat het geschiedt nadat het bestuur het initiatief heeft genomen inzake het onderwerp waarover geadviseerd wordt. Het is niet 'initiërend' advies, in die zin dat de rvc als het ware samen met het bestuur het beleid voorbereidt. ${ }^{56}$ De grenzen zijn hier uiteraard niet scherp. Het voorgaande wil slechts benadrukken dat de adviserende taak van de rvc niet een zelfstandige betekenis heeft, maar gezien moet worden als uitvloeisel van de controlerende taak.

Het is niet in strijd met de wet dat naast de rvc een adviserend college gevormd wordt. De statuten kunnen aan dit college zekere bevoegdheden toekennen, bijvoorbeeld tot het ontvangen van informatie of, bij een gewone vennootschap, tot het bijwonen van bepaalde vergaderingen van de rvc, of tot het verstrekken van advies aan het bestuur. Maar een zodanige adviserende instantie mist, in tegenstelling tot de rvc, de bevoegdheid om besluiten met betrekking tot het beleid te nemen die voor de vennootschap bindend zijn. Omdat de rvc zeggenschap heeft met betrekking tot het beleid van de vennootschap, is zijn rechtspositie principieel anders dan die van het adviserend college. Dit verklaart waarom het advies van de rvc voor het bestuur niet vrijblijvend is. Deze gebondenheid an het advies vindt zijn grondslag in de controlerende positie die de wet -in het bijzonder wanneer het volledige structuurregime van toepassing is- aan de rvc binnen de vennootschap toekent. ${ }^{57}$ Het advies van de rvc is niet vrijblijvend omdat het afkomstig is van een orgaan dat in het systeem van de wet een zekere verantwoordelijkheid draagt voor het beleid van de vennootschap. Ik zou willen stellen dat het bestuur het advies van de commissarissen in beginsel dient te ontvangen met de bereidheid om het op te volgen.

Niet uitgesloten is dat onder omstandigheden het advies van de rvc als bindend moet worden beschouwd. Hiervoor is reeds gesteld dat de rvc

56. Het is niet in strijd met de wet dat een of meer commissarissen specifieke deskundigheid aanwenden met betrekking tot bestuurszaken. Een dergelijk handelen behoort echter niet per se tot de toezichthoudende taak van de commissaris. Alsdan handelt betrokkene mogelijk niet als toezichthouder, doch in zijn hoedanigheid van deskundige.

57. In gelijke zin Sanders/Westbroek (199l), blz. 179. 
gehouden kan zijn in het bestursbeleid te interveniëren. Een dergelijke ingreep zal geboden zijn wanneer het beleid van het bestuur naar het oordeel van commissarissen definitief gefaald heeft. Het eigenlijke ingrijpen in het bestuursbeleid kan worden voorafgegaan door een instructie aan het bestuur.

Uit het hiervoor gestelde volgt dat de controlerende en besturende taak van respectievelijk de rvc en het bestuur niet geheel onafhankelijke grootheden zijn. In de grenslinie raken het commissariële toezicht en de bestuursactiviteit elkaar. Het beleid van de vennootschap -hoewel geïnitieerd en uitgevoerd door het bestuur- is in enige mate aan de rvc toe te rekenen, omdat de raad, die terzake van dat beleid een zekere zeggenschap heeft, daarmee heeft ingestemd. In zoverre is de adviserende werkzaamheid van de rvc, zoals gezegd, niet gelijk aan die van een gewone adviseur. De bezwaren van een niet onbelangrijk deel van de literatuur tegen de samenloop van controle en advies ${ }^{58}$ houden mijns inziens onvoldoende rekening met het afgeleide karakter van de adviesfunctie van commissarissen of, zo men wil, met het primaire karakter van de toezichthoudende taak.

\section{Aanvullende taken}

\section{Statutaire vrijheid?}

Art. 140 lid 2 noemt als enige taken van de rvc het houden van toezicht op en het verstrekken van advies aan het bestuur. Lid 3 voegt hieraan toe: "De statuten kunnen aanvullende bepalingen omtrent de taak en de bevoegdheden van de raad en van zijn leden bevatten." Dit artikellid doet de vraag rijzen naar de verhouding tussen het eerste en het derde lid, omdat het eerste lid een limitatieve opsomming van de taken van de rvc lijkt te bevatten, terwijl het derde lid toebedeling van andere taken lijkt toe te staan.

Het artikel spreekt over aanvullende bepalingen omtrent "taak en bevoegdheden" van de raad en zijn leden. De betekenis van deze termen moet allereerst worden verklaard. Sprekend over het bestuur maakt Huizink ${ }^{59}$ een onderscheid tussen functie, taak en bevoegdheid. Functie noemt hij de rol die het bestuur -en hetzelfde geldt voor andere organen- in de vennoot-

58. Illustratief Ophof (1988), blz. 192: "Hoe moet de arme raadgever handelen die tevens met toezicht is belast? Is hij de ware raadgever, dan zal hij, wordt de raad niet opgevolgd, in het toezicht tekort schieten. Dwingt hij zijn raad af, dan is hij geen raadgever, maar een gebieder en in feite medebestuurder."

59. Diss. (1989), blz. 16. 
schap speelt. Taak is de aan het betrokken orgaan opgedragen werkzaamheid. Bevoegdheden zijn, tenslotte, instrumenten om de taken uit te voeren. Terecht wijst Huizink op de samenhang tussen deze begrippen. De aan de organen toegekende bevoegdheden zijn gericht op de vervulling van een bepaalde vennootschappelijke taak. Andersom bepalen de bevoegdheden van het orgaan in kwestie de inhoud van zijn taak. Gesteld zou kunnen worden dat behoorlijke taakvervulling hetzelfde is als behoorlijke uitoefening van bevoegdheden. In tegenstelling tot Huizink meen ik echter dat tussen functie en taak geen relevant verschil bestaat. De rol die een orgaan binnen de vennootschap vervult, staat naar mijn mening gelijk met de werkzaamheden die het moet verrichten. ${ }^{60}$ In het vervolg wordt daarom slechts over taken en bevoegdheden gesproken.

De verhouding tussen taken en bevoegdheden is geen constante. In het algemeen kan niet zonder meer worden gezegd dat de uitoefening van een bepaalde taak zekere bevoegdheden veronderstelt. Mij beperkend tot de raad van commissarissen blijkt dit reeds uit de verschillende wettelijke regimes die voor hetzelfde orgaan bestaan. De toezichthoudende taak van de raad van commissarissen brengt bijvoorbeeld, in de visie van onze wetgever, niet noodzakelijk mede de macht om de leden van bestuur te benoemen en te ontslaan. Alleen in bepaalde gevallen heeft de wetgever aan de rvc op dit punt bevoegdheden willen toekennen. Of een bevoegdheid tot een bepaalde taak behoort, en andersom, of een bepaalde taak een zekere bevoegdheid inhoudt, is een kwestie van wetsuitleg. Alleen tegen de achtergrond van de wettelijke regeling kan de verhouding tussen taken en bevoegdheden worden bepaald. Het positieve recht markeert de grenzen waarbinnen de autonomie van de rechtsgenoten zich dient te ontplooien. Daarbij dient, gezien het bepaalde in art. 25, het uitgangspunt te zijn dat de vennootschappelijke inrichting door de wet dwingend wordt geregeld, waardoor de beschikkingsmacht van de rechtsgenoten beperkt is. In zoverre lijkt mij dat de bepaling van art. 140 lid 3 cum grano salis moet worden genomen.

Het is niet aannemelijk dat aan de rvc andere taken kunnen worden opgedragen dan de toezichthoudende taak. De zin van de wettelijke regeling is mijns inziens dat aan de rvc alleen een toezichthoudende functie kan toekomen. Deze stelling vindt in de eerste plaats steun in de parlementaire

60. Huizink (t.a.p.) noemt als voorbeeld de boekhoudplicht van het bestuur (art. 14, thans art. 10), welke plicht hij als een taak van het bestuur ziet die uit de leidinggevende functie volgt. Naar mijn mening is de boekhoudplicht niets anders dan een wettelijke concretisering van de algemene bestuurstaak. Anders gezegd: boekhouden $i s$, rechtens, besturen. 


\section{AANVULLENDE TAKEN}

geschiedenis. In de MvT op de Structuurwet ${ }^{61}$ worden toezicht en advies de "hoofdtaken" van de rvc genoemd. Andere taken die aan de rvc kunnen worden opgedragen zijn volgens de MvT als uitvloeisels daarvan te beschouwen. Voorts wordt opgemerkt ${ }^{62}$ dat wel aanvulling op, doch geen afwijking van de wettelijke bepalingen is toegestaan. ${ }^{63}$ Statutaire of reglementaire voorzieningen in strijd met de wettelijke bepalingen moeten als nietig worden aangemerkt.

In de tweede plaats is dit standpunt is in overeenstemming met de letterlijke tekst van art. 140 lid 3, waar gesproken wordt over "aanvullende bepalingen omtrent de taak" van de rvc en zijn leden.

In de derde plaats is een restrictieve uitleg van art. 140 lid 3 in overeenstemming met het wettelijk systeem. De toebedeling van taken aan de verschillende organen van de vennootschap is, voor zover deze organen wettelijk geregeld zijn, dwingend recht. Het ligt niet in de macht van de rechtsgenoten aan de rvc een andere dan de wettelijk voorgeschreven taak toe te kennen.

Op grond hiervan moet worden geconcludeerd dat in de visie van de wetgever toezicht en advies de eigenlijke taken zijn van de rvc. Andere taken die hiermee in strijd zijn kunnen niet aan de rvc worden opgedragen. Men denke bijvoorbeeld aan een statutaire bepaling volgens welke de rvc of eén van zijn leden belast is met het bestuur van de vennootschap waar het belangrijke transacties betreft.

Aan deze overwegingen doet niet af dat de wetgever in bepaalde gevallen (artt. 146 en 134 lid 4) de bestuurstaak aan de rvc heeft willen opdragen. ${ }^{64}$ Dat de toezichthoudende taak de normale taak van de rvc is, sluit niet uit dat onder bepaalde omstandigheden dit orgaan met de bestuurstaak wordt belast. Een zodanige omstandigheid doet zich met name voor wanneer de bestuurders feitelijk (art. 134) of rechtens (art. 146) in de onmogelijkheid verkeren hun taak (naar behoren) uit te oefenen. Daarbij moet worden bedacht dat de rvc in genoemde gevallen niet steeds gehouden is de bestuurstaak zelf te vervullen. De statuten kunnen volgens artt. 134 lid 4 en 146 andere personen met de uitoefening van de betrokken bevoegdheden belasten. Bovendien is de commissaris die een bestuurstaak uitoefent, zolang deze situatie voortduurt, niet gerechtigd om de bevoegdheden uit te oefenen die aan de commissariële taak verbonden zijn. Zulks

61. Maeijer, Wetsgeschiedenis, IXf-Art. 50 (II) - 1 .

62. Maeijer, Wetsgeschiedenis, IXf-Art. 50 (II) - 3 .

63. Maakt men ernst met het dwingend karakter van het wettelijk systeem, dan zal deze mogelijkheid tot 'aanvulling' in de hiervoor aangegeven beperkte zin dienen te worden verstaan $(\S 1, I V)$.

64. Naar mijn mening is de uitoefening van bevoegdheden voortvloeiende uit genoemde artikelen als een bestuursdaad te beschouwen. Zie hierover onder $\S 3$,III. 
wil niet zeggen dat hij als commissaris defungeert, maar slechts dat hij zijn commissariële bevoegdheden tijdelijk niet kan uitoefenen. Alsdan kan stricto sensu niet worden gesproken van het uitoefenen van andere taken naast het houden van toezicht en het verstrekken van advies. De toezichthoudende en adviserende taak worden, zolang de waarneming van de bestuurstaak voortduurt, niet uitgeoefend. De commissaris handelt onder de gegeven omstandigheden als bestuurder (art. 151).

Hoe dient dan art. 140 lid 3 te worden geïnterpreteerd met betrekking tot de aanvullende bepalingen inzake de taak van de rvc en van zijn leden? Aan de parlementaire stukken ${ }^{65}$ ontleen ik het voorbeeld van de gedelegeerde commissaris. De statuten kunnen bepalen dat er een zodanige commissaris zal zijn. Zij kunnen de werkzaamheden van deze commissaris nader regelen. Daarbij gelden de door het Departement ( $\$ 6$ Dep. Ritchtl.) aangegeven grenzen: "Deze taak mag geen inbreuk maken op de taak en bevoegdheden die de wet toekent aan de raad van commissarissen; de taak mag geen bevoegdheid inhouden die niet aan de raad zelf toekomt." Het wettelijk systeem biedt enige ruimte om met inachtneming van de dwingende toekenning van taken en bevoegdheden de werkzaamheden van deze organen statutair -dat wil zeggen naar het inzicht van de rechtsgenotennader te bepalen. Zoals reeds hiervoor is gesteld gaat het bij deze nadere regelingen om een concretisering van de toezichthoudende taak. Zij beogen de wijze waarop de taak wordt uitgeoefend aan de behoeften van het concrete geval aan te passen. ${ }^{66}$

Hebben de rechtsgenoten geen mogelijkheid om de rvc met een andere taakstelling toe te rusten dan die welke wettelijk is voorgeschreven, meer ruimte bestaat waar het de toebedeling van bevoegdheden betreft. ${ }^{67}$ Deze vrijheid is in het gewone model groter dan in het structuurregime. In laatstgenoemd regime heeft de wetgever de positie van de rvc verregaand op dwingende wijze geregeld. Doch ook daar is een nadere regeling van het commissariaat niet uitgesloten. Zo mag bijvoorbeeld worden aangenomen $^{68}$ dat de lijst van ex art. 164 goed te keuren besluiten statutair kan worden uitgebreid. Ook kan aan de rvc een zekere beslissingsbevoegdheid

65. Maeijer, Wetsgeschiedenis, IXf - Art. 50 (II) - I.

66. Geen bezwaar bestaat mijns inziens tegen een statutaire voorziening volgens welke de rvc gehouden is met een zekere regelmaat een bericht uit te brengen over zijn toezichthoudende taak (zie hierover Mengelberg, TVVS 1978, blz. 201 e.v. en Geersing. TVVS 1979, blz. 17 e.v.). De rechtspositie van de rve wordt door een dergelijke bepaling niet geraakt. De bepaling houdt in een concretisering van de verantwoordingsplicht van de rve jegens de rechtspersoon.

67. Hierover nader $\S 11$.

68. Vgl. Dep. Richtl. $\$ 9$ jo. 14 en Van Schilfgaarde (1992), nr. 144. 


\section{AANVULLENDE TAKEN}

worden toegekend, bijvoorbeeld bij staking van stemmen binnen het bestuur. Bij gewone vennootschappen zijn de mogelijkheden uitgebreider. Aan de rvc kunnen bevoegdheden worden toegekend met betrekking tot benoeming, schorsing en ontslag van bestuurders. De bevoegdheden van de algemene vergadering terzake van deze aangelegenheden kunnen bijvoorbeeld door middel van voordrachtsrechten, die aan de rvc worden toegekend, worden beperkt. Doch in ieder geval dienen de aan de rvc toegekende bevoegdheden zowel in het gewone als in het structuurregime gericht te zijn op de vervulling van de toezichthoudende taak.

\section{Vervanging van bestuurders bij ontstentenis of belet}

De statuten dienen voorschriften te bevatten over de wijze waarop in het bestuur van de vennootschap wordt voorzien in geval van ontstentenis of belet van bestuurders (art. 134 lid 4). Het Departement legt deze bepaling verschillend uit al naar gelang zij toegepast wordt op een gewone- dan wel op een structuurvennootschap waarvoor art. 162 geldt. In het eerste geval dienen de statuten de persoon aan te wijzen die belast zal zijn met het voorlopig bestuur. Mogelijk is ook dat de statuten een orgaan aanwijzen dat verder zorgt voor benoeming van de tijdelijke bestuurder(s). Wanneer de bestuurders echter conform art. 162 worden benoemd, dient de bestuurstaak aan de rvc of aan een door dit orgaan aan te wijzen persoon te worden opgedragen ( $\$ 14$ Dep. Richtl.). Het is niet duidelijk op welke rechtsgrond het Departement zich baseert bij het opleggen van deze verplichting aan structuurvennootschappen. De wet schrijft slechts voor dat de statuten een voorziening dienen te bevatten voor het geval van belet of ontstentenis van bestuurders, maar zij zwijgt over de inhoud van de voorziening. Met Westbroek $^{69}$ zie ik in dit zwijgen van de wet een reden om in dezen voorzichtigheid te betrachten en geen andere verplichtingen op te leggen dan de wet uitdrukkelijk voorschrijft. Verdedigd kan echter worden ${ }^{70}$ dat de departementale bepaling strookt met de ratio van de Structuurwet.

De persoon die gedurende de belet- of ontstentenisperiode in het bestuur van de vennootschap voorziet, is vanaf het moment van aanstelling, bestuurder van de vennootschap. Op de tijdelijke bestuurder zijn de wettelijke bepalingen over het bestuurderschap van toepassing voor zover het tijdelijke karakter van de aanstelling zich niet daartegen verzet. Van der

69. Rechtspersonen, Commentaar Departementale Richtlijnen, $\S 14$, aant. 10.

70. Zo Westbroek, t.a.p. 
Grinten $^{71}$ denkt hier anders over. Hij acht het wettelijke vertegenwoordigingsregime niet op de tijdelijke bestuurder van toepassing. Uit deze stelling volgt dat, indien de tijdelijke bestuurder de wettelijke vertegenwoordigingsbevoegdheid niet heeft, die in beginsel aan iedere bestuurder toekomt, deze 'bestuurder' geen bestuurder in de zin der wet is. Het is echter niet in te zien waarom art. 130 niet op de tijdelijke bestuurder van toepassing zou zijn. Het enkel verrichten van daden van bestuur (art. 151) brengt weliswaar niet vertegenwoordigingsbevoegdheid mede en ook mist de feitelijke bestuurder in de zin van art. 138 lid 7 deze bevoegdheid, maar de tijdelijke bestuurder van art. 134 lid 4 is, anders dan de personen genoemd in de artt. 151 en 138, niet iemand die de wet voor bepaalde doeleinden als bestuurder aanmerkt. Hij is de persoon die de bestuurstaak tijdelijk- waarneemt en dient, met deze taak rechtsgeldig belast zijnde, zonder restrictie als bestuurder te worden beschouwd. In de wet zijn geen gronden te vinden om, met betrekking tot de tijdelijke bestuurder, een scheiding aan te brengen tussen bestursbevoegdheid en vertegenwoordigingsbevoegdheid. Voor dit standpunt pleit de systematische plaatsing van artikel 134 in Afdeling 5, handelend over "Het bestuur van de naamloze vennootschap en het toezicht op het bestur". Ook de Hoge Raad leert ${ }^{2}$ dat "indien commissarissen bij ontstentenis of schorsing van den directeur optreden ter behartiging van de belangen der vennootschap, hun taak en bevoegdheid niet uitgaan boven die welke ingevolge de wet of de akte van oprichting aan het bestuur toekomen." Taak en bevoegdheid gaan inderdaad niet uit boven die van het bestuur omdat de rvc in dat geval bestuur is. Taak en bevoegdheid zijn die van het bestuur.

Een andere vraag is of de tijdelijke bestuurder reeds om het enkele feit dat hij deze hoedanigheid bezit, vertegenwoordigingsbevoegd is. Naar mijn mening bestaat ook op dit punt geen aanleiding om de tijdelijke bestuurder anders te behandelen dan de normale bestuurder. Vertegenwoordigingsbevoegdheid is niet inherent aan de aanstelling als bestuurder. ${ }^{73}$ Op dezelfde

71. Handboek, nr. 255. Zoals Van der Grinten, maar dan met betrekking tot de gedelegeerde commissaris, Kamphuisen (1956), blz. 44. Volgens Geerts (1988), blz. 102, is de tijdelijke bestuurder "materieel" wel, doch "formeel" geen bestuurder.

72. HR 5 november 1954, NJ 1956, 321 (Tactor - Ritz Lounge). A-G Langemeijer gaat in zijn conclusie eveneens uit van de samenval van bestuurs- en vertegenwoordigingsbevoegdheid (blz. 743, r.k.). I.c. ging het om een probleem van tegenstrijdig belang (art. 51 WvK oud). Doch de overwegingen van de Hoge Raad te dien aanzien gelden ook voor de problematiek van belet of ontstentenis in zoverre in beide situaties de rvc de bestuurstaak -voor een bepaalde transactie respectievelijk voor een bepaalde tijd- waarneemt. Zie ook Hof 's-Gravenhage 29 april 1966, NJ 1967, 247.

73. Behalve in het geval dat het bestuur slechts uit eén lid bestaat. Vgl. HvJ-EG 12 november 1974, 32/74, Jur. 1974, blz. 1201 (Haaga GmbH). 
manier als de gewone bestuurder deze bevoegdheid kan ontberen, behoeft de tijdelijke bestuurder niet per se vertegenwoordigingsbevoegd te zijn. De toekenning van de vertegenwoordigingsbevoegdheid kan afhankelijk zijn van de statutaire bepalingen. Bepalen de statuten dat elke bestuurder vertegenwoordigingsbevoegd is, dan is de tijdelijke bestuurder dat ook. Aanstelling met onthouding van de vertegenwoordigingsbevoegdheid zou in strijd met de statuten en daarom nietig zijn. Voorts kan de vertegenwoordigingsbevoegdheid van de tijdelijke bestuurder, voor zover uit de wet niet anders voortvloeit, niet -althans niet met externe werking- worden beperkt (art. 130 lid 3). ${ }^{74}$

Een volgende vraag is of de commissaris die tijdelijk met het bestuur is belast recht heeft op de beloning van een bestuurder. Dit is niet het geval omdat de beloning niet inherent is aan het bestuurderschap. ${ }^{75}$ Wanneer de commissaris voor zijn commissariaat een beloning ontvangt, kan worden aangenomen dat deze vergoeding mede geldt voor het geval hij tijdelijk met de bestuurstaak is belast. Mogelijk is echter dat de vennootschap in strijd handelt met de goede trouw, indien zij aan de tijdelijke bestuurder een beloning onthoudt die, bijvoorbeeld krachtens gebruik, aan een bestuurder pleegt te worden toegekend. ${ }^{76}$

De waarneming van de bestuurstaak kan in beginsel aan een ieder worden opgedragen. Het feit dat de benoemde persoon commissaris is, doet daar niet aan af. In de rechtspraak is de geoorloofdheid van een tijdelijke combinatie van bestuur en toezicht aanvaard. ${ }^{77}$ Omdat de tijdelijke bestuurder de bestuurstaak uitoefent, doet zich een bijzondere situatie voor indien deze functie door een commissaris wordt vervuld. ${ }^{78}$ Door de be-

74. Anders Handboek, nr. 255.

75. Dit wordt mijns inziens door Kamphuisen (1956), blz. 44, over het hoofd gezien wanneer hij, met een beroep op Rb. Amsterdam 30 november 1934, NJ 1935, 1302 , stelt dat de commissaris die tijdelijk daden van bestuur verricht geen bestuurder is aangezien hij geen recht heeft op bestuurdersbeloning. Het recht op beloning ontbeert de commissaris niet omdat hij geen bestuurder zou zijn, maar omdat de bestuurder op zich geen recht op beloning heeft.

76. Evenzo Handboek, nr 263.

77. Hof 's-Gravenhage, 29 april 1966, NJ 1967, 247 en OK 19 december 1985, gecasseerd op gronden die i.c. irrelevant zijn door HR 24 december 1986, NJ 1987,903 (Westhaven). Laatstgenoemd arrest betrof een structuurvennootschap. Daarover Rood, TVVS 1986, p. 54-55 en Slagter, TVVS 1987, p. 73-74.

78. $\$ 14$ Dep. Richtl. moet mijns inziens letterlijk worden geïnterpreteerd waar bepaald wordt dat de statuten "de regeling" met betrekking tot belet of ontstentenis aan de rvc dienen op te dragen. De rvc regelt de vervanging van het bestuur, maar de raad kan niet als orgaan de bestuurstaak uitoefenen. In gelijke zin Geerts, (1988) blz.

(Wordt vervolgd...) 
noeming als bestuurder worden de functies van bestuurder en toezichthouder aan eenzelfde persoon toevertrouwd. Hoewel deze situatie niet past in het systeem van de wet $^{79}$, kan de tijdelijke vereniging van besturende en toezichthoudende taak in eenzelfde persoon onder buitengewone omstandigheden en met zekere restricties geoorloofd zijn. Benoeming van een commissaris als tijdelijke bestuurder is gerechtvaardigd omdat de vennootschap zonder continuïteit in de besluitvorming überhaupt niet kan handelen. De vennootschap kan niet functioneren zonder een besturend orgaan.

De commissaris die als tijdelijke bestuurder wordt aangesteld verliest niet eo ipso zijn hoedanigheid van commissaris. ${ }^{80} \mathrm{Hij}$ is echter niet bevoegd om de met de besturende en toezichthoudende functies gepaard gaande bevoegdheden gelijktijdig uit te oefenen, omdat beleidsbepaling en beleidscontrole onverenigbare functies zijn. ${ }^{81}$ Verdedigd wordt ${ }^{82}$ dat i.c. sprake is van een tegenstrijdig belang-situatie en dat de betreffende regels hier van overeenkomstige toepassing zijn. Hier doet zich echter geen probleem van tegenstrijdigheid van belangen tussen een bepaalde persoon en de vennootschap voor. Hier bestaat een probleem van onverenigbaarheid van functies. Omdat de strekking van de bepalingen op dit punt verschillend is, is er geen ruimte voor analogische toepassing van art. $146 .{ }^{83}$

De samenval van bestuurderschap en commissariaat kan tot minder gewenste resultaten leiden. Zo bijvoorbeeld wanneer voor een concrete transactie zowel een besluit van het bestuur als de goedkeuring daarvan door de rvc vereist is. In het meermalen aangehaald arrest van het Hof 'sGravenhage van 29 april 1966 was de situatie nog klemmender omdat de rvc slechts uit één lid bestond dat tijdelijk in het bestuur van de vennoot-

78.(...vervolg)

102. De samenval van bestuur en toezicht in hetzelfde orgaan -ook voor beperkte tijd- is in strijd met de wet.

79. Vgl. nader hierover onder $\S 15$,II.

80. Vgl. Hof 's-Gravenhage van 29 april 1966, NJ 1967, 247.

81. Vgl. \& 105, Abs 2 AktG: "Nur für einen im voraus begrenzten Zeitraum, höchstens für ein Jahr, kann der Aufsichtsrat einzelne seiner Mitglieder zu Stellvertretern von fehlenden oder behinderten Vorstandsmitglieder bestellen. Eine wiederholte Bestellung oder Verlängerung der Amtszeit ist zulässig, wenn dadurch die Amtszeit insgesamt ein Jahr nicht übersteigt. Während ihrer Amtszeit als Stellvertreter von Vorstandsmitglieder können die Aufsichtsratsmitglieder keine Tätigkeit als Aufsichtsratsmitglied ausüben. Das Wettbewerbsverbot des $\$ 88$ gilt für sie nicht."

82. Geerts (1988), blz. 103-104.

83. Vgl. ook HR 29 januari 1943, NJ 1943, 198 (Sinnis/Schipper): "... dat in het stelsel van ons Wetboek van Koophandel het geval van tegenstrijdig belang in art. 51 een eigen regeling heeft gevonden, wel te onderscheiden van de in art. $48 b$ behandelde figuur van ontstentenis of belet van den bestuurder." Evenzo Handboek, nr. 255. 
schap moest voorzien. Het ging i.c. om de toekenning van zekere pensioenrechten door het bestuur, voor welke handeling de goedkeuring van de rvc statutair vereist was. I.c. waren de pensioenrechten door de tijdelijke bestuurder toegekend die tevens commissaris was. Het Hof overwoog hieromtrent: "Zo al zou moeten worden aangenomen dat het vereiste van toestemming van commissarissen geldt ook voor het geval dat het met het beheer belaste college van commissarissen niet meer dan één persoon telt, dan ligt in de door app. W. als met het beheer belaste enige commissaris verrichte toekenning van pensioenrechten de hiervoor vereiste toestemming van commissarissen besloten." Het is niet duidelijk of het Hof de statutair vereiste goedkeuring ook in een geval als het onderhavige noodzakelijk acht. Naar mijn mening is zulks niet het geval. Immers, een impliciete noch een uitdrukkelijke goedkeuring van de rvc heeft onder de gegeven omstandigheden enige zin. Een dergelijke 'goedkeuring' is een contradictio in terminis omdat de commissariële goedkeuring in het systeem van de wet -ook van de vroegere wet ${ }^{34}$ - gedacht is als de fiattering van een bestuurshandeling door een van het bestuur onafhankelijke instantie. In zoverre is het niet mogelijk dat de als bestuur handelende rvc zijn eigen handelingen goedkeurt. Hieraan doet niet af dat de goedkeurende instantie in twee hoedanigheden zou kunnen optreden, nl. als bestuur en als rvc. Immers, de goedkeuring dient, om als zodanig te kunnen gelden, niet enkel formeel in orde te zijn. Zij dient daarnaast inhoudelijk aan de voorstelling van de wetgever te beantwoorden. Zij dient, met andere woorden, door een daadwerkelijk onafhankelijke instantie te zijn verleend.

Overigens vervalt het goedkeuringsvereiste slechts indien alle commissarissen verhinderd zijn in de uitoefening van hun bevoegdheden. Zolang andere commissarissen in staat zijn hun taak uit te oefenen ${ }^{85}$, worden de bevoegdheden van de rvc door de overblijvende leden uitgeoefend, zelfs indien de wet of de statuten een minimum aantal leden voorschrijven. ${ }^{86}$

84. Vgl. HR 1 april 1949, NJ 1949, 465 (Doetinchemse IJzergieterij).

85. Bij een structuurvennootschap mag worden aangenomen dat de rvc -buitengewone omstandigheden daargelaten- zijn taak steeds zal kunnen uitoefenen. Bij belet of ontstentenis van het bestuur zal niet de gehele rvc -minimaal bestaande uit drie leden (art. 158 lid 3)- de bestuurstaak kunnen overnemen. Een of meer commissarissen dienen hun ambt te blijven uitoefenen.

86. Aldus ook Pres. Rb 's-Gravenhage, 17 mei 1988, KG 1988, 250, die zijn standpunt motiveert (r.o. 5) met een beroep op de MvT op art. 158 lid 3, op de tekst van de tweede volzin van dit artikel, op het collegiale karakter van de commissariale taak en op het gezond verstand. 


\section{Vertegenwoordiging van de vennootschap bij tegenstrijdig belang}

Art. 146 verleent aan commissarissen de bevoegdheid om de vennootschap te vertegenwoordigen indien tussen deze en een of meer van haar bestuurders zich een geval van tegenstrijdig belang voordoet. De wettelijke regeling is erg lacuneus. Op deze plaats zal ik mij zoveel mogelijk beperken tot die kwesties die de rvc regarderen.

In de eerste plaats rijst de vraag naar het toepassingsbereik van de norm. Volgens Dorresteijn ${ }^{87}$ is sprake van tegenstrijdig belang bij "een belang, privé of kwalitatief, dat slechts ten koste van de rechtspersoon kan worden gediend en dat van invloed kan zijn op de belangenafweging door een bestuurder of commissaris in de uitoefening van zijn functie." Deze schrijver beperkt dit tegenstrijdig belang-begrip tot het zogenaamde formeel tegenstrijdig belang, dat wil zeggen tot die rechtshandelingen en gedingen waarbij de bestuurder als formele wederpartij van de vennootschap optreedt. ${ }^{88}$ Dorresteijn baseert zijn standpunt hoofdzakelijk op de parlementaire geschiedenis van art. 146 (c.q. daaraan voorafgaande bepalingen).

Deze beperkte uitleg is niet bevredigend. In de eerste plaats kan worden getwijfeld aan de stelling dat de wetgever art. 146 zuiver formeel bedoeld heeft. De MvT op art. 51e van het Ontwerp 1910 merkt, ter adstructie van de toekenning van aanwijsbevoegdheid aan de ava, op: "Het kan voorkomen dat tusschen directie en commissarissen zulke nauwe vriendschapsbanden blijken te bestaan, dat het college van commissarissen allerminst geacht kan worden de aangewezen lieden te bevatten om met kracht tegen het bestuur op te treden." ${ }^{19}$ Het "met kracht tegen het bestuur optreden" staat echter op gespannen voet met het enkel verrichten van vertegenwoordigingshandelingen dat inherent is aan een formele opvatting van art. 146. Voorts betoogt Dorresteijn ${ }^{90}$ dat, volgens de MvT op het Gewijzigd Ontwerp 1925, het tweede lid van voornoemd artikel (dat commissarissen bevoegd verklaarde conservatoire matregelen tegen de bestuurders te nemen) geschrapt werd omdat commissarissen "moeten kunnen handelen naar omstandigheden." Dit "moeten kunnen handelen naar omstandigheden" pleit naar mijn mening eveneens tegen een formele uitleg. ${ }^{91}$ Ook de jurisprudentie hanteert in ieder geval een ruimer tegen-

87. Diss. (1989), blz. 6.

88. T.a.p. blz. 32 en 52 . Zie in gelijke zin de door Dorresteijn (blz. 43) aangehaalde auteurs.

89. Belinfante (1929), blz. 95 ; mijn curs.

90. (1989), blz. 29.

91. De verwijzing naar het betreffend passage van de MvT heb ik niet kunnen verifieren. 
strijdig belang begrip, waarbij het zgn. indirect tegenstrijdig belang eveneens onder de werking van art. 146 wordt gebracht. ${ }^{92}$ En, tenslotte, Dorresteijn zelf stelt dat het "voor de hand ligt" art. 146 toe te passen op bepaalde transacties waarbij geen sprake is van tegenstrijdig belang in formele zin. Zo bijvoorbeeld in het geval dat een vennootschap bestuurder is van een andere vennootschap. ${ }^{93}$ Wanneer tussen beide vennootschappen een rechtshandeling zou worden verricht en dus art. 146 van toepassing zou zijn, acht Dorresteijn toepassing van dit artikel geboden wanneer als wederpartij van de vertegenwoordigde vennootschap de bestuurder van de vennootschap-vertegenwoordiger zou optreden.

Dit laatste voorbeeld laat zien welke moeilijkheden verbonden zijn aan een formele uitleg van art. 146. Mijns inziens dient de steun voor de interpretatie van de wettelijke bepaling niet in haar onzekere antecedenten maar in haar ratio te worden gezocht. In deze zin lijkt overeenstemming te bestaan over het feit dat het hier besproken artikel een norm bevat die de belangen van de rechtspersoon beoogt te beschermen ${ }^{94}$ in situaties waarin de bestuurder die ten behoeve van de rechtspersoon moet optreden, het risico loopt eigen belangen voor die van de rechtspersoon te stellen. ${ }^{95} \mathrm{Om}$ benadeling van de rechtspersoon te voorkomen draagt de wet de verantwoordelijkheid voor de transactie over aan een andere instantie. ${ }^{96}$ Maar omdat benadeling van de rechtspersoon een feitelijk gegeven is, is het mijns inziens niet mogelijk de problematiek van het tegenstrijdig belang vanuit een formeel-juridische benadering op te lossen. $\mathrm{Bij}$ het begrip 'belang' gaat het om het (veelal economisch) voordeel dat de transactie voor betrokkenen kan opleveren en niet om de personen die als partij optreden bij de rechtshandeling. Of dit voordeel aan de bestuurder zelf toekomt of aan een derde tot wie de bestuurder in een relevante rechtsverhouding staat, en of het voordeel de bestuurder in privé dan wel in een

92. Indirect belang is het belang dat de bestuurder zijdelings bij de transactie heeft omdat een derde met wie hij enige relatie heeft de onmiddellijke belanghebbende is. Zie met name HR 14 november 1940, NJ 1941, 321 (Maas/Amazone). Voorts Rb. Breda 31 maart 1989, KG 1989, 204 en Hof 's-Hertogenbosch 25 april 1990, NJ 1991, 136 (White Products).

93. (1989), blz, 53 .

94. Anders echter Sanders/Westbroek (1991), blz. 187, voor wie art. 146 bedoeld is om de belangen van de aandeelhouders te beschermen. Het feit dat de belangen van de aandeelhouders tevens beschermd worden omdat zij in de regel parallel lopen met die van de vennootschap, wil niet zeggen dat zij de adressaten van de norm zijn.

95. Vgl. Freijters, De NV 42 (1964-65), blz. 57 en Maeijer (1993), blz. 12.

96. Omdat de regeling van aanvullend recht is, kan statutair worden bepaald dat de transactie zal worden verricht door de persoon die het tegengestelde belang heeft. 
bepaalde kwaliteit bereikt, is i.c. zonder betekenis. ${ }^{97}$ Mij dunkt dat de toepasselijkheid van art. 146 bepaald wordt door de aanwezigheid van een dusdanig belang van de bestuurder bij de transactie dat onbehoorlijke vervulling van de bestuurstaak te duchten valt. Dit risico van taakvervulling anders dan in het belang van de vennootschap is mijns inziens het beslissende element van het hier besproken artikel. Dit risico brengt steeds een (potentiële) benadeling van de vennootschap met zich mee. Om deze benadeling te voorkomen vertrouwt de wet de bestuurstaak terzake van de transactie aan de rvc toe.

Twee conclusies kunnen uit het voorgaande worden getrokken. In de eerste plaats is het naar mijn mening mogelijk dat art. 146 eveneens van toepassing is in situaties waarin -strikt gesproken- geen tegenstrijdigheid van belangen bestaat. Het belang van de vennootschap kan, met andere woorden, parallel lopen met dat van de bestuurder zonder dat zulks in de weg staat aan toepasselijkheid van art. 146. Ik geef een voorbeeld. Indien de vennootschap een kantoorpand moet kopen en zowel de bestuurder als een derde een geschikt pand aanbieden, kan toepassing van art. 146 geboden zijn. Benadeling van de vennootschap schuilt niet in de transactie op zich, welke zakelijk gezien correct kan zijn, doch in het risico dat de bestuurder bij de taakuitoefening zijn eigen belang laat prevaleren boven dat van de vennootschap. ${ }^{98}$

Uit het voorgaande volgt voorts dat niet elke transactie waarbij bestuurder en vennootschap als partijen tegenover elkaar staan, toepasselijkheid van art. 146 medebrengt. ${ }^{99}$ Zulks is slechts het geval indien het tegenstrij-

97. Een materiële uitleg van het begrip tegenstrijdig belang wordt ook bepleit door Lowensteyn. Rechtspersonen, art. 146, aant. 2; Slagter, TVVS 1991, blz. 75 en Van Leeuwen, TVVS 1987, blz. 30. Met enige reserves waar het betreft het kwalitatief belang Maeijer (1993), blz. 13.

98. Deze omstandigheid wordt in de zaak HCS 2 (Rb Amsterdam 1 augustus 1988, KG 1988, 341) mijns inziens zowel door eisers als door de President uit het oog verloren. Zoals de President terecht stelt, brengt het enkele feit dat de bestuurder voordeel overhoudt aan een transactie met de vennootschap, niet de ongeldigheid van de transactie (dat wil zeggen van het daaraan ten grondslag liggend besluit) met zich mee. Uit de uitspraak blijkt overigens dat het besluit bevoegdelijk door bestuur en rve van HCS werd genomen. Echter, niet het mogelijke persoonlijke voordeel dat de bestuurder aan de transactie overhoudt bepaalt op zich de toepasselijkheid van art. 146. maar het gevaar van onbehoorlijke taakvervulling, dat hem onbevoegd kan maken terzake van de besluitvorming over de transactie. Anders dan hier A-G Mok in zijn conclusie voor HR 7 februari 1992, NJ 1992, 438, sub 4.3 (Astro). Volgens de Hoge Raad geeft het door de A-G verdedigd oordeel "geen blijk van een onjuiste rechtsopvatting."

99. Zo echter Dorresteijn (1989), blz, 53, en WPNR 5969 (1990) blz. 476. Daarmee verwerpt schrijver zijn (stipulatieve) definitie van tegenstrijdig belang (blz. 6), 
tegenstrijdig belang in kwestie de bestuurder belet zijn taak naar behoren te vervullen. Voor zover dat niet het geval is, kan van een rechtens relevant 'belang' niet worden gesproken. ${ }^{100}$ I.c. geldt, gezien de gelijke strekking van art 146 en 137 op dit punt, een soortgelijke uitzondering als in art. 137 lid 2 voorzien is met betrekking tot rechtshandelingen van de enig aandeelhouder met de vennootschap.

De vraag of de vennootschap gebonden is aan een door het bestuur in strijd met art. 146 aangegane rechtshandeling betreft een vertegenwoordigingsprobleem en dient conform de regels van vertegenwoordiging te worden opgelost. Omdat het al of niet aanwezig zijn van een tegenstrijdig belang een interne aangelegenheid van de vennootschap is, kan de wederpartij van de vennootschap uitgaan van het feit dat het bestuur de bestuursmacht heeft om de rechtshandelingen bedoeld in art. 146 aan te gaan. De wederpartij die niet op de hoogte is noch behoort te zijn van de bevoegdheidsbeperking van de bestuurder, behoeft geen rekening te houden met de daarmee gepaard gaande beperking van zijn vertegenwoordigingsbevoegdheid en zal derhalve worden beschermd (art. 130 lid 3 jo. 3:61 lid 2 BW). Voor zover de bestuurder die het tegenstrijdig belang heeft, de formele wederpartij van de vennootschap is, is een beroep op onbekendheid met de bevoegdheidsbeperking niet mogelijk. ${ }^{101}$

Adressaat van art. 146 is de rvc en niet de individuele leden van dit college. $^{102}$ De door Van Schilfgaarde ${ }^{103}$ aangevoerde argumenten tegen deze stelling -de wet spreekt over "commissarissen" en toebedeling van de vertegenwoordigingsbevoegdheid aan de individuele commissarissen sluit bovendien aan bij dezelfde toebedeling aan bestuurders- zijn niet overtuigend. Het taalkundig argument kan zonder verdere steun in het positieve recht geen afbreuk doen aan het collegialiteitsbeginsel dat aan de wettelijke regeling van het commissariaat ten grondslag ligt. ${ }^{104}$ De analogie met de bestuurders gaat gezien het verschil in taakstelling tussen rvc en bestuur niet op. De vertegenwoordigingsbevoegdheid van de individuele bestuurder berust op een expliciete toekenning van de wetgever, welke als noodzake-

99.(...vervolg)

omdat niet elke transactie van belang is voor de belangenafweging in het kader van zijn taakvervulling. Zoals hier Schwarz (1991), blz. 49.

100. Evenzo Maeijer (1993), blz. 12 en 109, die op dit punt zijn eerdere visie (formeel belang levert steeds tegenstrijdig belang op) relativeert. Zie zijn noot onder HR 7 februari 1992, NJ 1992, 438.

101. Vgl. hierover De Kluiver/Schwar, TVVS 1993, blz. 119.

102. Zo ook Handboek, nr. 278. Vgl. ook art. 57 lid 4.

103. (1992), nr. 69.

104. Vgl. hiervoor $\& 1$,III. 
lijk complement van de bestuursbevoegdheid wordt gezien. Omdat deze laatste bevoegdheid aan commissarissen slechts in uitzonderlijke gevallen toekomt, is het aannemelijk, gezien het feit dat het hier gaat om handelingen die stricto sensu buiten de toezichthoudende taak vallen, dat de wetgever geen uitzondering op het collegialiteitsbeginsel heeft willen maken.

In meerderheid gaat de doctrine er van uit dat aan de rvc slechts de vertegenwoordigings- maar niet de beslissingsbevoegdheid met betrekking tot de gewraakte transactie toekomt. ${ }^{105}$ Min of meer impliciet ligt aan dit standpunt de gedachte ten grondslag dat toekenning aan de rvc van de beslissingsbevoegdheid gelijk staat met het uitvoeren van de bestuurstaak, hetgeen in strijd is met de toezichthoudende functie van de rvc. De doctrine aanvaardt zonder meer dat in geval van tegenstrijdig belang de wet aan het bestuur de vertegenwoordigingsbevoegdheid ontneemt, maar heeft er kennelijk moeite mee dat de beslissingsbevoegdheid terzake van de transactie bij een andere instantie wordt geplaatst. Wel wordt ingezien dat de taak van de rvc i.c. niet beperkt kan worden tot het enkel vertegenwoordigen van de vennootschap op grond en onder de voorwaarden van een door het bestuur genomen besluit. Dit zou immers elke betekenis aan de norm ontnemen. Het wettelijk stelsel komt er dan op neer dat er sprake dient te zijn van "medewerking van commissarissen" aan de totstandkoming van de transactie. ${ }^{106}$ Doch evenmin als het nemen van bestuursbesluiten tot de taak van de rvc behoort, behoort daartoe het verrichten van vertegenwoordigingshandelingen, welke inherent zijn aan het handelen krachtens art. 146. De wet legt de vertegenwoordigingsbevoegdheid bij de rvc omdat zij het risico wenst te voorkomen dat het bestuur een transactie aangaat waarbij het vennootschappelijk belang ondergeschikt wordt gemaakt aan het eigen belang. $\mathrm{Er}$ is geen reden om op dit punt vertegenwoordigings- en bestuursbevoegdheid te scheiden. De eerste is, zoals gezegd, complement van de tweede, en hetzelfde motief dat de wet beweegt om aan het bestuur de vertegenwoordigingsbevoegdheid te ontzeggen, brengt mede dat ook de bestuursbevoegdheid ontnomen wordt. De rve is dan vertegenwoordigingsen bestuursbevoegd.

Mijns inziens moet afstand worden genomen van de gedachte dat de rve in het geheel geen daden van bestuur mag verrichten. De artt. 134 lid 4 en 146 dragen, voor zover statutair niet anders is bepaald, de bestuurstaak onder de omstandigheden in die artikelen genoemd, over aan de rvc. De raad, c.q. zijn leden, treedt bij toepasselijkheid van die artikelen als bestuur

105. Zo Handboek, nr. 278. Vgl ook Van Schilfgaarde (1992), nr. 96; Dorresteijn (1989), blz. 55; Timmerman (1993), blz. 6; Maeijer (1993), blz. 16.

106. Zo Handboek, nr. 278. 
op. ${ }^{107}$ Op hem en/of zijn leden, al naar gelang wie de bestuursdaad verricht, is de voorziening van art. 151 van toepassing. Daarom dient de commissaris die de bestuurder bij belet of ontstentenis vervangt of die de vennootschap in een tegenstrijdig belang-situatie vertegenwoordigt, als bestuurder te worden aangemerkt. Hiertegen wordt wel aangevoerd dat de vertegenwoordiger ex art. 146 niet handelt "krachtens enige bepaling der statuten of krachtens besluit der algemene vergadering", zoals art. 151 voorschrijft. ${ }^{108}$ Deze uitleg van art. 146 lijkt echter niet valide. Het verschil in rechtsgrond waaraan de handelende persoon zijn bevoegdheid ontleent, kan er niet toe leiden dat ten aanzien van hetzelfde rechtsfeit tegenstrijdige rechtsgevolgen gelden. Zo zou volgens de hier bestreden uitleg de commissaris die krachtens statutaire aanwijzing of krachtens besluit van de ava in een geval van tegenstrijdig belang optreedt, wel als bestuurder zijn aan te merken, doch niet indien dezelfde commissaris die terzake van dezelfde transactie op grond van art. 146 zou optreden, zulks omdat de statuten te dien aanzien niets bepalen. Naar mijn mening leunt deze visie te zwaar op de letterlijke tekst van het artikel. De toelichting op de voorganger van art. 146 verschaft hierover meer duidelijkheid. "Het doel der bepaling is daarom (...) dat niet alleen zij, die steeds onder blijvende omstandigheden met het bestuur der vennootschap werden belast, bestuurder zijn in het oog der wet, doch ook zij, die louter voor enkele aangelegenheden of onder bepaalde omstandigheden daden van bestuur verrichten, nu ook voor die aangelegenheden, onder die omstandigheden bestuurders zijn, met alle de rechten en verplichtingen die op bestuurders in deze rusten. De gedelegeerde commissaris, die als bestuurder optreedt bij ontstentenis van de directie, de agent van een bijkantoor, de adjunctdirecteur in den vreemde, zij allen zijn, voor zoover zij zelfstandig de vennootschap vertegenwoordigen, bestuurders in de zin der wet." ${ }^{109}$ De wet maakt in deze geen onderscheid naar de titel waarop de bestuursbevoegdheid berust. Het artikel spreekt over aanwijzing krachtens statuten of krachtens besluit van de ava omdat het denkbaar is dat de rechtsgenoten aan een functionaris bestuursbevoegdheden toekennen zonder hem bestuurder te noemen. ${ }^{110}$ Dat de persoon die krachtens de wet bestuursdaden verricht bestuurder is, spreekt voor zich. Het behoeft niet met zoveel

107. Evenzo terzake van art. 146 Slagter (1990), blz. 263.

108. Zo Lowensteyn, Rechtspersonen, art. 151, aant. 2 en Handboek, nr. 263.

109. MvT Ontwerp 1910, art. 52b, Belinfante (1929), blz. 97. In hoeverre alle aangehaalde voorbeelden even gelukkig zijn, kan daargelaten worden.

110. Zie MvT, t.a.p.: "Het moet (...) niet mogelijk zijn personen, die niet den naam van bestuurders dragen met daden van bestuur te belasten, zonder dat op die personen ook de voor de bestuurders bepaalde aansprakelijkheid rust." (Curs. ook in het origineel). 
woorden te worden bepaald in een artikel dat zich richt tot oprichters/aandeelhouders.

Voor de toepasselijkheid van art. 151 is derhalve het verrichten van bestuursdaden beslissend. Wie dat doet, wie bestuursbevoegdheden uitoefent, draagt de daarbij behorende verantwoordelijkheid. De rechtsgrond waarop de bevoegdheid berust, is echter niet van belang.

\section{Richtsnoer bij de taakuitoefening: het belang van de vennootschap}

\section{Noodzaak van een standpuntbepaling}

Het onderwerp 'vennootschappelijk belang' heeft $z 0$ veel aandacht in binnen- en buitenlandse literatuur gekregen dat het mij noodzakelijk lijkt te motiveren waarom ik op deze plaats nog eens op het onderwerp terugkom.

Een reden daarvoor is dat het positieve recht nu eenmaal het vennootschappelijk belang noemt als doel waarnaar de commissarissen zich dienen te richten bij hun taakvervulling. Het is daarom geboden, indien het positieve recht geanalyseerd wordt, bij deze cruciale bepaling stil te staan.

Anderzijds lijken het aantal en de kwaliteit van vele publicaties over het thema een nieuwe poging tot analyse van begin af aan overbodig te maken. Bovendien, omdat vrijwel alle denkbare standpunten zijn ingenomen, zou het niet moeilijk zijn er één uit te kiezen, waarbij men zich zou kunnen aansluiten. Dit is zonder meer juist, en reeds nu kan worden gesteld dat onderstaande beschouwingen in grote lijnen overeen komen met de opvatting die in Nederland met name door Löwensteyn steeds is verdedigd. "'I Aan deze opvatting, volgens welke het belang van de vennootschap grosso modo gelijk staat met het belang van de gezamenlijke aandeelhouders, heb ik inderdaad niet meer dan een precisering toe te voegen, en in dit opzicht zal ik zoveel mogelijk afzien van een nieuwe apologie. Hier zou ik veeleer de argumenten willen toetsen op grond waarvan de Nederlandse doctrine vrijwel unaniem tot de conclusie komt dat het vennootschapsbelang -wat dit ook moge inhouden- in ieder geval iets anders is dan het belang van de gezamenlijke aandeelhouders.

De zojuist aangehaalde doctrine leert dat het vennootschappelijk belang niet het aandeelhoudersbelang is omdat de vennootschap "een van de oprichters vrijstaand (zelfstandig) instituut, beheerst door eigen regels" is. ${ }^{112}$ De voedingsbodem van deze gedachte is de zogenaamde institutietheorie van M. Hauriou. Omdat deze theorie mij een dubieuze steun lijkt,

111. Vgl. (1959), blz. 136; (1970), blz. 85 e.v. en (1985), blz. 720 e.v.

112. Van Schilfgaarde (1992), nr. 3. 


\section{DE INSTITUTIELEER}

zou ik thans daaraan enige aandacht willen besteden.

\section{De rechtspersoon: contract noch instituut}

Wat is een institutie? Hauriou geeft hiervan de volgende definitie: "Une institution est une idée d'oeuvre ou d'entreprise qui se réalise et dure juridiquement dans un milieu social." Hij vervolgt: "Pour la réalisation de cette idée, un pouvoir se organise qui lui procure des organes; d'autre part, entre les membres du groupe social intéressé à la réalisation de l'idée, il se produit des manifestations de communion dirigées par les organes du pouvoir et règlées par des procédures. ${ }^{113}$ De institutie kent drie elementen, namelijk een idee, een georganiseerde macht en de adhesiebetuigingen die de vinder -zo noemt Hauriou hem- van dit idee in het sociaal milieu ontmoet. ${ }^{114}$ Met zijn theorie wil Hauriou de geboorte, het voortbestaan en het einde van de instituties verklaren.

Het voornaamste bezwaar dat vanuit een juridisch perspectief tegen deze theorie kan worden aangevoerd, is dat de door haar gegeven sociologische uitleg van rechtsfiguren weinig zegt over hun juridische inhoud. ${ }^{115}$ Dit is des te meer het geval omdat in deze theorie nagenoeg elke sociale realiteit als institutie kan worden aangemerkt. En zo beschouwt een voor-

113. M. Hauriou, La théorie de l'institution et de la fondation, Cahiers de la Nouvelle Journée, nr. 4, Paris 1925, blz. 10.

114. Zie voor een toepassing van de institutionele gedachte op de onderneming J.J.M. van der Ven, Sociologische opmerkingen over de onderneming, De NV 26 (194849), blz. 139 e.v. en $J$. van Haren, Wezen en doel van de moderne onderneming, De NV 40 (1962-63). Dit laatste artikel is geschreven n.a.v. het rapport 'Open Ondernemerschap' van de Teldersstichting. Op blz, 374 e.v. bevat dit rapport een korte -en op belangrijke punten onjuiste- uiteenzetting van de leer van Houriou die tot een ander standpunt dan dat van Van der Ven leidt. Onjuist -want onvolledig- is dat "Hauriou's leer van de Institution een theorie over het wezen van de rechtspersoonlijkheid" is (blz. 375). Dit is in zoverre onjuist dat niet alleen de rechtspersoonlijkheid, maar talloze andere rechtsfiguren verklaard worden. Hauriou ((1925), blz. 10-11) noemt met zoveel woorden de "institution-chose": "elle est une institution parce qu'en tant qu'idee elle se propage et vit dans le milieu social, mais, elle n'engendre pas une corporation qui lui soit propre." Incorrect is eveneens dat de leer van Hauriou "bij uitstek individualistisch is" (blz. 380). Doel van Hauriou's leer is juist "la querelle de l'objectif et du subjectif" ((1925), blz. 3), dat wil zeggen: tussen collectivisme en individualisme, tussen maatschappij en individu, te overwinnen. Zie over dit punt, en in het algemeen als een uitstekende samenvatting van Houriou's institutionalisme, W. Fikentscher, Maurice Hauriou und die institutionelle Rechtslehre, FS L. Raiser, Tübingen 1974, blz. 559 e.v. Zie voorts J.A. Schellekens, De leer over de "institution" bij M.Hauriou, Nijmegen 1945.

115. Zie de kritiek bij Wolff (1933), blz. 35 en 260 en Fikentscher (1975), blz. 569. 
aanstaande leerling ${ }^{16}$ van Hauriou inderdaad als institutie: een treinstation en een 'fonds de commerce' (blz. 92), de staking (blz. 381), de volksvertegenwoordiger (blz. 405), de algemene voorwaarden (blz. 424), en aan deze reeks kunnen onder andere worden toegevoegd het huwelijk, de Staat... en de naamloze vennootschap. Uit deze opsomming kan reeds worden geconcludeerd dat, wat men ook moge denken van de sociologische precisie van het begrip, de institutie een dermate vaag begrip is, dat daaraan rechtens geen betekenis kan worden toegekend.

Het is overigens de vraag of in de juridische literatuur het begrip niet buiten zijn eigen proporties is gebracht. In dit verband is het interessant te vernemen wat Hauriou aan het einde van zijn essay stelt: "Réduisons aux plus justes proportions la portée de ce mémoire. Il est intitulé "essai de vitalisme social" et c'est là toute sa prétention. Les idées directrices, (...) sont le principe vital des institutions sociales, elles leur communiquent une vie propre séparable de celle des individues, dans la mesure où les idées elles-mêmes sont séparables de nos esprits et réagissent sur eux. Nous n'allons pas au delà de la constatation de ce phenomène. " 117 De institutieleer verklaart inderdaad op zeer eigen wijze hoe een feitelijke realiteit kan bestaan en voortleven gescheiden van de personen die haar hebben geïnitieerd of die daarbij betrokken zijn. Maar het is niet in te zien hoe aan deze sociologische verklaring concrete gevolgen verbonden kunnen worden voor het positieve recht. Dit onderscheid tussen zijn en behoren, tussen het sociale verschijnsel dat regeling behoeft en de eigenlijke juridische regeling, is in onze literatuur mijns inziens onvoldoende onderkend.

Paradigmatisch in dit verband is het standpunt van Huizink. ${ }^{118}$ Hij stelt: "De vennootschap-rechtspersoon is een organisatorisch geheel dat los staat van de aandeelhouders-oprichters; een zelfstandig instituut met een eigen organisatie en bevoegdheidsverdeling waar organen zoals de algemene vergadering van aandeelhouders èn de individuele aandeelhouders aan gebonden zijn." De stelling dat de rechtspersoon "los staat" van de aandeelhouders-oprichters is op zijn minst voor relativering vatbaar. De rechtspersoon immers ontstaat niet zonder de wilsverklaring van de oprichter(s), terwijl de aandeelhouders -die, georganiseerd als vergadering, orgaan van de rechtspersoon zijn- tot ontbinding van de rechtspersoon kunnen overgaan. Terecht stelt Huizink dan ook dat orgaan en aandeelhouders aan de wettelijke en statutaire regeling -die zij zichzelf hebben gegeven- gebonden zijn. Maar als zij aan de vennootschap gebonden zijn, is het niet in te zien hoe zij los van hem kunnen staan. Of het 'instituut' feitelijk los staat van

116. G. Renard, La Thérie de I'Institution, Paris 1930.

117. (1925), blz. 45 .

118. (1989), blz. 2. 


\section{DE INSTITUTIELEER}

de aandeelhouders-oprichters is een andere kwestie. Ik meen dat dit in ieder geval een stelling is die niet opgaat voor talloze vennootschappen wellicht voor de meeste vennootschappen- waar de aandeelhouders het instituut wel degelijk als iets eigens beschouwen. En de stelling gaat zeker niet op wanneer de oprichter tevens enig aandeelhouder en bestuurder is. Weliswaar kan niet worden ontkend dat er in andere gevallen "verschil bestaat tussen de vennootschap zoals zij op papier -ten overstaan van de notaris- tot stand komt en de vennootschap als operationele eenheid. " 119 Wat de juridische betekenis is van dit verschil, is echter niet in te zien.

De institutionele opvatting wil in wezen iets bewijzen dat sedert Savigny niet meer bestreden is en dat is dat de aandeelhouder(s) en de rechtspersoon verschillende rechtssubjecten zijn. Om dit juridisch feit sociologisch te verklaren kan men een beroep doen op de institutionele leer, maar men dient wel te bedenken dat de resultaten van het sociologisch onderzoek niet transponeerbaar zijn op de normatieve realiteit van het recht. Het is dan ook onjuist om ter bestrijding van de these dat de nv een contractuele rechtsverhouding is de nv als institutie aan te merken. ${ }^{120}$ Rechtens heeft men deze categorie niet van node. De nv is niet zijn aandeelhouders, noch de vrucht van een onder hen bestaande contractuele verhouding. $\mathrm{Zij}$ is een ander rechtssubject: $\mathrm{zij}$ is rechtspersoon.

Wanneer derhalve de ontwikkeling van het positieve recht verklaard wordt als een voortschrijdend institutionaliseringsproces van de rechtsper$\operatorname{soon}^{121}$, dient deze verklaring te worden gerelativeerd. Zeker is dat de institutionalisering niet een rechtsnorm of een complex van rechtsnormen betreft, maar de sociale realiteit die genormeerd wordt. Vanzelf spreekt dat indien de wetgever niet te zeer achter de sociale ontwikkelingen wil lopen, de norm verandert wanneer de te normeren realiteit dat doet. Het vennootschapsrecht is aan deze veranderingen onderworpen niet alleen in de laatste jaren maar reeds vanaf zijn ontstaan. ${ }^{122}$ Men kan betogen dat indirect de veranderingen in wetgeving en rechtspraak toe te schrijven zijn aan het proces van institutionalisering, maar positiefrechtelijk wordt daarmee niets

119. Zo Van Schilfgaarde (1992), nr. 3. Cursivering ook aldaar.

120. Onjuist is voorts contract en institutie als tegengestelde begrippen te stellen omdat ook de contractuele vennootschappen volgens de institutieleer als instituties zijn te beschouwen. In deze zin heeft Van Schilfgaarde gelijk wanneer hij de institutionalisering' van de contractuele vennootschappen verdedigt. Zie, Vrijheid van vennootschap, s'Jacob-bundel, 1975, blz. 254.

121. Zo Van Schilfgaarde, Vennootschapsrecht na 27 jaren, Slagter-bundel, 1988, blz. 253 e.v.

122. Een duidelijk voorbeeld hiervan geeft het ontstaan van het 'instituut' commissariaat. Zie E.J.J. van der Heijden, De ontwikkeling van de Naamloze Vennootschap in Nederland voor de codificatie, diss. 1908, blz. 61 e.v. 
gewonnen.

Naar mijn mening is aan de institutionele leer in onze literatuur een betekenis gegeven die haar niet toekomt. Wellicht zou dit zonder gevolgen zijn gebleven wanneer deze theorie binnen het domein zou zijn gehouden waarvoor zij was bedacht, $\mathrm{nl}$. als rechtssociologische verklaring van bepaalde maatschappelijke verschijnselen. Doordat echter deze verklaring is betrokken op het positieve recht, heeft zij mijns inziens meer schade dan profijt opgeleverd. Dit blijkt vooral uit de betekenis die de term vennootschappelijk belang mede daardoor heeft gekregen.

\section{Het belang van de vennootschap}

De juridische problemen waartoe het vennootschappelijk belang aanleiding geeft, zijn naar het mij voorkomt te herleiden tot de problematiek rond het wezen van de rechtspersoonlijkheid, die op haar beurt nauw verbonden is met die van het subjectieve recht. Omdat omtrent deze begrippen zeer uiteenlopende visies bestaan, is het niet verwonderlijk dat het onderwerp 'belang van de vennootschap' eveneens omstreden is. In het algemeen ${ }^{123}$ kan worden gesteld dat de fictie-theorie eerder tot de ontkenning van een zelfstandig belang van de rechtspersoon leidt dan Gierke's Organismuslehre. Dit omdat, terwijl in de realiteitstheorieën rechtspersonen werkelijk bestaande verbanden zijn, namelijk organische eenheden die in het maatschappelijk verkeer een zelfstandig leven leiden en die door het recht worden erkend, in eerstgenoemde theorieën de rechtspersoonlijkheid wezenlijk bepaald wordt door het recht, dat in de verlening van rechtspersoonlijkheid niet gebonden behoeft te zijn aan een concrete feitelijke realiteit. Weliswaar zijn binnen deze twee stromingen nuanceringen aan te brengen, en worden thans met name de metaforen waarmee het realiteitsgehalte van de rechtspersoon in vroegere geschriften werd 'verklaard'24, algemeen verworpen, doch als uitgangspunt blijft gelden dat de aanvaarding van een zelfstandig vennootschapsbelang de erkenning impliceert van een zeker, reëel bestaan van de drager van dat belang. Deze drager is in de institutionele theorie de institutie.

Het probleem van het vennootschappelijk belang behoort in de vorm zoals dit zojuist is witeengezet tot de rechtstheorie. Het positieve recht behoeft zich niet in te laten met de theorieënstrijd. En de wetgever heeft

123. Zie uitgebreid over de problematiek het standaardwerk van $H . J$. Wolff, Organschaft und juristiche Person. Band I, Berlin 1933, passim.

124. Zie H.J. Wolff (1933), blz. 4 e.v. en $M$. Wolf, On the Nature of Legal Persons, The Law Quarterly Review, Vol. CCXVI (1938), blz. 498 e.v. 
dan ook verklaard in deze geen partij te willen kiezen. ${ }^{125}$ Maar het zou ijdel zijn te pretenderen dat de rechtsorde zich hieraan geheel kan onttrekken. Dat de wetgever geen expliciete keuze heeft gemaakt voor een of andere opvatting omtrent het wezen van de rechtspersoonlijkheid, betekent niet dat hij, wanneer hij de rechtspersoon heeft erkend, dat wil zeggen zijn juridisch bestaan aanvaard heeft, in het geheel geen opvatting zou hebben.

In deze zin lijkt mij dat in ons recht de realiteit van de rechtspersoon zich beperkt tot die van het positieve recht. De rechtspersoon is niet een institutionele realiteit zoals deze door de institutieleer verstaan wordt. De rechtspersoon kan rechtens bestaan zonder dat er van enige feitelijke realiteit, al of niet van de aandeelhouders "los staand", sprake hoeft te zijn. De rechtspersoon ontstaat reeds bij de oprichting overeenkomstig de eisen van de wet, waarbij de wilsverklaring van een of meer personen als constituerend moment vereist is. Zeer goed denkbaar is dat een institutie niet voorhanden is. ${ }^{126}$

Dat in ons recht de realiteit van de rechtspersoon bepaald wordt door de rechtsorde en niet door de institutionele realiteit die genormeerd wordt, blijkt voorts uit de bepalingen van het internationaal privaatrecht. Juist wanneer de toepasselijkheid van verschillende rechtsordes in het geding is, is het duidelijk hoezeer onze rechtsorde uitgaat van het fictief -in de zin van niet feitelijk bepaald- wezen van de rechtspersoonlijkheid. De Hoge Raad heeft immers verklaard dat het bestaan van rechtspersonen (vennootschappen) beheerst wordt "door het recht dat structuur en inrichting van de vennootschap en het functioneren van haar organen beheerst, dus door het recht volgens hetwelk de vennootschap is opgericht." ${ }^{127}$ Zou onze rechtsorde ernst maken met de institutionele gedachte, dan zou in ons IPR niet het incorporatiestelsel maar het stelsel van de siège réel gelden. Immers, niet in het land van oprichting, doch in het land waar de bedrijfsuitoefening geschiedt dient de institutie en daarmee de rechtspersoon te worden geloka-

125. Van Zeben, Parlementaire Geschiedenis Boek 2 BW, blz. 14.

126. Anders kennelijk Mendel, Rede 1989, blz. 12, die stelt: "Uitzonderingen daargelaten is een N.V. of B.V. zonder onderneming niet compleet." Reeds echter het enkele feit dat er "uitzonderingen" bestaan, impliceert dat in tegenstelling tot hetgeen schrijver beweert, de vennootschap wel degelijk "compleet" is wanneer zij geen ondernemende activiteit ontplooit.

127. HR 20 april 1990, NJ 1991, 560 (Natco 2). Dit is ook het vrijwel unaniem standpunt in de doctrine. Zie Asser-Van der Grinten II, nr. 56 e.v. en P. Vlas, Praktijkreeks IPR, deel 9, Rechtspersonen, Deventer 1993, nr. 53 e.v. Zie voorts art. 72 van de "Schets van een Algemene Wet betreffende het Internationaal Privaatrecht", augustus 1992. 


\section{liseerd. ${ }^{128}$}

Uit het voorgaande volgt dat ons rechtssysteem de rechtspersoon beschouwt als een rechtsverschijnsel waarvoor de toepasselijke normen, en niet de "vennootschap als operationele eenheid"129, als institutie bepalend zijn. ${ }^{130}$ Mijns inziens kan daarom worden geconcludeerd dat de uitgangspunten van de fictie-theorie beter in ons recht inpasbaar zijn dan die van de reëel verband-theorie.

Intussen is met het voorgaande de problematiek van het vennootschappelijk belang nog niet opgelost. Gebleken is slechts dat, uitgaande van het geldende recht, de institutieleer in ieder geval geen steun kan bieden voor de constructie van een entiteit die het beweerde belang draagt. Wat deze problematiek betreft zou ik het volgende willen stellen. Indien het vennootschappelijk belang begrepen wordt als de resultante ${ }^{|3|}$ van de afweging van alle (?) bij de rechtspersoon betrokken (?) belangen, is het niet duide-

128. Zulks impliceert niet dat de feitelijke realiteit steeds zonder betekenis is. Het is mogelijk dat bepaalde normen van het land waar de rechtspersoon zijn werkelijke zetel heeft als voorrangsregels hebben te gelden. Het feit echter dat deze normen als voorrangsregels worden beschouwd, impliceert dat het vennootschapsstatuut -en dus de rechtspersoonlijkheid- reeds bepaald is door het recht van het land van oprichting.

129. Zo Van Schilfgaarde (1992), nr. 3.

130. Van Schilfgaarde (Piercing Van Schilfgaarde (1990), blz. 70-71) geeft dit zelf toe, naar aanleiding van de kritiek van Timmerman (t.a.p., blz. 3 e.v.). Wat deze kritiek betreft gelden ook de overwegingen in de tekst. Wanneer Timmerman poneert dat er "een spanningsrelatie bestaat tussen onderneming en vennootschap" (blz. 5) en dat "de rechtsfiguur $n v / b v$ beperkt autonoom is in relatie tot de onderneming" (blz. 6), komen wij niet tot een beter begrip van hetgeen de vennootschap is. Het gaat hier om de inderdaad "spannende" verhouding tussen norm en feit. Deze verhouding wordt mijns inziens vertroebeld wanneer ter verklaring van het juridische element overwegingen van feitelijke aard worden aangedragen. Zo naa mijn mening Timmerman (blz. 6): "Deze beperkte autonomie in de nv/bv biedt de ruimte om de rechtvaardigheid die het recht dient te bevorderen in de verhoudingen binnen de onderneming een woordje te laten meespreken." Er is i.c. geen sprake van "een beperkte autonomie." Het gaat on twee überhaupt verschillende realiteiten: om 'zijn' en 'behoren'. Dat de positieve regeling een neerslag is van feitelijke verhoudingen en collectieve overtuigingen is voor het overige een vanzelfsprekendheid die, sprekend over het vennootschapsrecht, geen nadere uitleg behoeft. De rechtvaardigheid die het recht dient te bevorderen moet in de eerste plaats uit het positieve recht volgen. Wanneer naar het oordeel van de rechtstoepasser deze rechtvaardigheid niet wordt bereikt, dient de rechtvaardige oplossing in een juiste interpretatie van het recht te worden gevonden. Bestaat er geen ruimte voor een zodanige interpretatie, dan dient wijziging van het recht te worden nagestreefl.

131. Zo, in de Nederlandse literatuur, onder andere Handboek, nr. 231 en Van Schilfgaarde, (1992), nr. 5. 


\section{HET VENNOOTSCHAPPELIJK BELANG}

lijk wat deze resultante is, en vooral hoe zij dient te resulteren. Deze opvatting ontmoet dezelfde bezwaren als elke vorm van zuivere Interessenjurisprudenz, welke bezwaren goed geillustreerd worden door "the wellknown incident reported to have occurred in a Harvard classroom. Student: 'We have to balance the interests.' Professor: 'Go ahead and balance them!'." 132 Zolang geen criterium wordt gegeven aan de hand waarvan de afweging dient plaats te vinden, leidt de resultante-opvatting tot een onmogelijkheid en is zij daarom onbruikbaar. ${ }^{133}$

Voor zover het vennootschappelijk belang begrepen wordt als een aan de vennootschap eigen belang dat 'los' of 'tegenover' het belang van aandeelhouders en andere belanghebbenden staat ${ }^{134}$, dient zich de vraag aan in hoeverre het überhaupt mogelijk is dat de rechtspersoon een belang heeft dat niet herleidbaar is tot dat van concrete mensen. Ik zou hierover het volgende willen stellen. ${ }^{135}$

Op dezelfde manier als over 'de wil van de rechtspersoon' gesproken wordt, kan over een vennootschappelijk belang worden gesproken. Echter, zoals de vennootschappelijke wil feitelijk de wil van de personen is die zitting hebben in de organen van de vennootschap, zo ook is het belang van

132. M. Rheinstein, Review: The Jurisprudence of Interests, Journal of Legal Education I (1948-49), blz. 472, opgenomen in Collected Works, Tübingen 1979, blz. 176.

133. Zie over de bezwaren tegen deze vorm van Interessenjurisprudenz Larenz (1991), blz. 49 e.v. Zoals in de tekst Lowensteyn (1970), blz. 86 en Mendel, Rede (1989), blz. 4.

134. Zo met name Maeijer, laatstelijk in De NV 67 (1989), blz. 1 e.v. en ook Mendel (1989), blz. 11. Laatstgenoemde schrijver bestrijdt Maeijer's visie, omdat deze "onvoldoende tot uitdrukking brengt en wellicht zelfs ontkent de eenheid die er in normale gevallen bestaat tussen de vennootschap en de met haar verbonden onderneming." Wat onder deze "eenheid 'vennootschap-onderneming' als zodanig" (blz. 14) verstaan moet worden wordt door Mendel, naar mijn mening, niet verklaard en volgt ook niet uit zijn definitie van het vennootschappelijk belang (t.a.p., blz. 14-15): "Het belang van de vennootschap inclusief de met haar verbonden onderneming -dat in meerdere of mindere mate, maar nooit volledig is geabstraheerd van de belangen van de aandeelhouders, werknemers en andere onmiddellijk betrokkenen- is haar belang bij zo voorspoedig mogelijke continuiteit." Niet duidelijk is verder aan wie de voorspoed dient toe te komen. Zie voorts de bespreking van Mendel's rede door Maeijer, RMTh 1990, blz. 465 e.v.

135. Vermelding verdient nog de analyse van Winter (1992), blz. 100 e.v. die beide in de tekst genoemde opvattingen met elkaar probeert te verzoenen. Schrijver relativeert terecht het verschil tussen beide opvattingen door er op te wijzen dat in de eerste visie meer de nadruk wordt gelegd op het proces om het vennootschappelijk belang te bepalen, terwijl in de tweede visie de nadruk wordt gelegd op het belang als resultaat van dat proces. Wanneer Winter echter stelt dat "het vennootschappelijk helang een eigen grootheid is" (blz. 102), komt zijn standpunt mijns inziens overeen met dat van Maeijer. 
de vennootschap een verzamelnaam voor de belangen van bepaalde mensen aan wie de rechtsorde zekere rechten jegens de vennootschap toekent. ${ }^{136}$ Doorgaans zullen deze belangen van vermogensrechtelijke aard zijn. Heeft men het over het vennootschappelijk belang als rechtsvraag, dan gaat het om vast te stellen aan wie het economische voordeel van de vennootschappelijke activiteit dient toe te komen. Mij dunkt dat dit de aandeelhouders zijn omdat de vennootschap, zoals hiervoor gesteld is, tot doel heeft hun belangen te dienen. De vennootschap bestaat als doelorganisatie om des aandeelhouders wille. Door Winter ${ }^{137}$ wordt wel gesteld: "Het eigenlijke doel van de vennootschap is de behoeften van deze belanghebbenden [aandeelhouders, werknemers, consumenten, leveranciers, afnemers, financiers, etc., JMBF] te bevredigen." Afgezien van het feit dat het niet is in te zien hoe een institutie de bevrediging van tegengestelde behoeften tot doel kan hebben, is de stelling mijns inziens in strijd met hetgeen de schrijver verderop beweert: "Het zo begrepen vennootschappelijk belang kan nader invulling krijgen met behulp van de statutaire doelomschrijving." Terecht wordt hier een verband gelegd tussen vennootschappelijk belang en statutair doel. Echter Winter trekt niet de mijns inziens correcte conclusie, namelijk dat de vennootschap het belang dient van hen die de zeggenschap hebben over het statutair doel: de oprichters/aandeelhouders.

In de literatuur wordt gesproken over het belang van de vennootschap. En hetzelfde kan worden gezegd van de vereniging, van de stichting en van de overige rechtspersonen. ${ }^{138}$ Tussen deze figuren bestaat niettemin een wezenlijk verschil waar het betreft de aard van het respectievelijk belang. Dit verschil wordt bepaald door het doel waarvoor de rechtspersoon is opgericht. Mijns inziens moet worden onderscheiden tussen rechtspersonen die een doel nastreven dat dienstbaar is aan de belangen van degenen die de rechtspersoon tot stand hebben gebracht of hem in stand houden, en rechtspersonen die een vreemd doel nastreven, dat wil zeggen een doel dat niet dienstbaar is aan de belangen van voornoemde personen. Men zou kunnen spreken van rechtspersonen met een 'instrumenteel' en met een 'finaal' karakter. De juridische zelfstandigheid van het rechtssubject is in beide gevallen dezelfde, niet echter de functie van de rechtspersoonlijkheid. Het wezen van instrumentele rechtspersonen wordt bepaald door hun dienende functie ${ }^{139}$ ten behoeve van de belangen van de oprichters. ${ }^{140}$

136. Uitwoerig hierover Wolff (1933), blz. 155 e.v.

137. (1992), blz. 103.

138. En zo ook van het belang van de maatschap $\left(1676,2^{\circ}\right.$ Boek $7 \mathrm{~A}$ BW), van de faillissementsboedel, ja, van een bibliotheek of een bos.

139. Vgl. Van der Grinten, De NV 30 (1952-53), blz. 86.

140. Op dit punt behoeft geen onderscheid te worden gemaakt tussen oprichters en personen die na de oprichting zeggenschap hebben in de rechtspersoon. 
Deze rechtspersonen zijn feitelijk niet zelfstandig ten opzichte van de oprichters, maar zijn juist de instrumenten ter bereiking van het doel dat de oprichters zich in hun eigen voordeel hebben gesteld. Het belang van deze rechtspersonen valt samen met het belang van de oprichters. Daarentegen hebben rechtspersonen met een 'finaal' karakter een zekere feitelijke zelfstandigheid ten opzichte van de oprichters, omdat het doel van de rechtspersoon een belang dient dat niet samen valt met het eigen belang van de oprichters. ${ }^{141}{ }^{142}$

Het onderscheid tussen finale en instrumentele rechtspersonen is wel in zoverre relatief dat elke rechtspersoon als doelorganisatie per definitie een instrument is ter realisatie van menselijke projecten. Wat ik hier wil benadrukken is dat het al of niet parallel lopen van het belang van de rechtspersoon met het (vermogensrechtelijk) belang van de oprichters/leden rechtens van grote betekenis is. Bij rechtspersonen met een finaal karakter hebben de aan de organen toekomende bevoegdheden een functioneel karakter. De bevoegdheden dienen te worden uitgeoefend ter verwezenlijking van het doel waarvoor de rechtspersoon is opgericht. Bij instrumentele rechtspersonen bestaan echter organen met en zonder functionele bevoegdheden. Bij de kapitaalvennootschappen hebben de bevoegdheden van bestuur en rvc een functioneel karakter. Bestuurders en commissarissen dienen de aan hun ambt verbonden bevoegdheden ${ }^{143}$ in het belang van de vennootschap uit te oefenen, dus voor het doel waarvoor de vennootschap tot stand is gebracht. ${ }^{144}$ Anders is de situatie bij de aandeelhouder, die "in het hem verleende stemrecht niet een recht in het belang van anderen is toevertrouwd, doch een eigen recht is gegeven om zijn belang in de

141. Dit sluit uiteraard niet uit dat de oprichters ook een eigen belang kunnen hebben bij de oprichting. De vermogende politicus die in verkiezingstijd een stichting opricht ter voorziening in de behoeften van eenzame bejaarden, kan daarmee beogen niet alleen de mens in nood te helpen, maar ook stemmen te winnen. Waar het i.c. om gaat is dat het belang van de rechtspersoon, met name in de zin van het vermogensrechtelijke voordeel, stricto sensu aan de oprichter vreemd is.

142. Interessant is er op te wijzen dat Von Savigny de (voorlopers) van de kapitaalvennootschappen niet als rechtspersonen beschouwt. Zij worden niet, zoals de rechtspersonen, in zijn System behandeld maar in het Obligationsrecht. Vgl. hierover Flume (1983), blz. 27: "Indem SAVIGNY die Aktionäre hinsichtlich der "Anstalt" wir würden sagen: hinsichtlich des Unternehmens der AG- als Gläubiger und Nutzungsberechtigte oder -welcher Meinung er den Vorzug gibt- als Miteigentümer einordnet, trennt er das wirtschaftliche Interesse der Aktionäre von der juristischen Person und der Mitgliedschaft, so daß nach seiner Ansicht bei der AG "die corporative Verfassung bloß die leichtere und vollständigere Vertretung nach außen zum Zweck hat"."

143. Strikt gesproken zijn het geen bevoegdheden van bestuurders of commissarissen.

144. Vgl. Lowensteyn, (1970), blz. 85. Zo ook terecht Winter (1992), blz. 104. 
vennootschap te dienen." 145 Dat het recht van de aandeelhouder in de vennootschap ter verwezenlijking van eigen belangen strekt, betekent dat voor de aandeelhouder -anders dan voor bestuurders of commissarissen- de vennootschap een instrumenteel karakter heeft. De rechtspositie van de aandeelhouder is slechts functioneel, dat wil zeggen aan het vennootschappelijk belang gebonden voor zover zijn autonomie bij de uitoefening van vennootschappelijke bevoegdheden niet onbeperkt is. Hij kan bijvoorbeeld niet stemmen met het uitsluitend voornemen om een mede-aandeelhouder te benadelen ${ }^{146}$ of in het algemeen zonder zich de belangen van medeaandeelhouders of anderen die met de rechtspersoon in een relevante rechtsverhouding staan in voldoende mate aan te trekken.

Het thema "vennootschappelijk belang" wordt verder gecompliceerd omdat dit belang vanuit twee perspectieven kan worden benaderd: een juridisch en een feitelijk, zo men wil economisch perspectief.

Bezien vanuit juridisch standpunt is de problematiek van het vennootschappelijk belang in wezen geen andere dan die van uitoefening van bevoegdheden in de rechtspersoon. Het 'vennootschappelijk belang' verwijst mijns inziens naar de norm waaraan de uitoefening van vennootschappelijke bevoegdheden dient te beantwoorden. De vraag of een bepaalde handeling in het belang van de vennootschap is, betekent de iure: aan welke beperkingen is het bevoegde orgaan onderworpen bij het nemen van het besluit dat tot de transactie zal leiden. Met andere woorden: het vennootschappelijk belang, als rechtsnorm begrepen, is niets anders dan het te goeder trouw uitoefenen van de vennootschappelijke bevoegdheden (art. 8). In zekere zin is dit reeds door Maeijer gesignaleerd waar hij stelt: "Naar mijn gevoel bevordert de erkenning van een eigen vennootschappelijk belang in sterke mate een systematisch en inzichtelijk peilen van de inhoud van de goede trouw die de betrekkingen binnen de n.v. beheerst." ${ }^{147}$ Geheel correct lijkt mij Maeijer's opvatting echter niet. Vennootschappelijk belang en goede trouw worden immers als verschillende grootheden tegenover elkaar geplaatst, waardoor mijns inziens niet duidelijk blijkt welke de functie van het begrip vennootschappelijk belang is: een feitelijke of een juridische. ${ }^{148}$

145. HR 30 juni 1944 , NJ 1944, 465 (Wennex).

146. HR 13 februari 1942, HR 1942, 360 (Baus / De Koedoe I).

147. In een commentaar op HR 30 oktober 1964, NJ 1965, 107 (Mante), De NV 42 (1964-65), blz. 155.

148. Maeijer spreekt terecht (1989), blz. 3, over het vennootschappelijk belang als "juridische realiteit", maar voor zover ik het kan zien, geeft hij een feitelijke invulling aan de term. Het belang van de vennootschap wordt immers (t.a.p.) aan dat van crediteuren, aan het algemeen belang tegenover gesteld. Ook spreekt hij

(Wordt vervolgd...) 
Desgewenst kan men ook het vennootschappelijk belang als feitelijke realiteit beschouwen, namelijk als vermogensrechtelijk voordeel. Het vennootschappelijk belang is dan het rechtmatige belang van de gezamenlijke aandeelhouders. De parallellie tussen vennootschappelijk belang en aandeelhoudersbelang vindt haar verklaring in het feit dat, zoals meermalen is aangegeven, in onze rechtsorde de vennootschap een instrument is ter realisatie van de doelstellingen van oprichters/aandeelhouders. Anderzijds wordt niet elk belang van de aandeelhouder(s) door de rechtsorde beschermd. Zijn (hun) belang dient de rechten van anderen, met name van andere personen die in verhouding staan tot de rechtspersoon, te respecteren. Daarom komt het vennootschappelijk belang niet per definitie overeen met hetgeen de algemene vergadering besluit. Een minderheidsaandeelhouder die de vergadering feitelijk controleert kan bijvoorbeeld van oordeel zijn dat hetgeen de ava -dat betekent feitelijk: hijzelf- besluit in het belang van de vennootschap is. De rechten van de overige aandeelhouders kunnen echter met zich meebrengen dat het vennootschappelijk belang iets anders inhoudt dan datgene wat de ava besloten heeft.

Beantwoording van de vraag in hoeverre de belangen van de aandeelhouders rechtmatig zijn, dient uiteraard van geval tot geval plaats te vinden. Omdat nv en bv kapitaalassociaties ${ }^{149}$ zijn, heeft mijns inziens als uitgangspunt te gelden dat de wettelijk en statutair op correcte wijze tot stand gekomen wil van de meerderheid van het kapitaal bepalend is. Wanneer alle aandelen in één hand zijn zal in de regel parallellie bestaan tussen vennootschappelijk belang en aandeelhoudersbelang. Doch, zoals gezegd, is niet elk unaniem genomen besluit per se gerechtvaardigd. Op dezelfde wijze als de eigenaar beperkt is in de uitoefening van zijn eigendomsrecht (art. 5:1 lid $2 \mathrm{BW}$ ), kan de aandeelhouder de rechten van derden niet zonder rechtvaardiging aantasten. Bij zijn winststreven dient de aandeelhouder naar de huidige rechtsopvattingen met name rekening te houden met de rechten van werknemers in dienst van de rechtspersoon. Het winststreven van de aandeelhouder vindt zijn grenzen daar waar de rechten van de werknemers onvoldoende in acht zijn genomen. ${ }^{150}$ Dit blijkt voor-

148.(...vervolg)

over het vennootschappelijk belang bij concerns of bij kleine vennootschappen. Indien echter het vennootschappelijk belang als het te goeder trouw uitoefenen van bevoegdheden wordt verstaan, is de betekenis van het begrip in alle feitelijke situaties rechtens dezelfde, hoewel de gevolgen waartoe de toepassing van het beginsel leidt verschillend kunnen zijn.

149. Zo nog steeds Handboek, nr. 231.

150. Vrijwel gelijkluidend Winter (1992), blz. 105. Omdat in de visie van Winter het vennootschappelijk belang een eigen grootheid is, die niet is te herleiden tot het

(Wordt vervolgd...) 
al wanneer de ondernemer krachtens besluit van de aandeelhouders de activiteit van de onderneming wenst te staken. ${ }^{151}$ Doch juist het feit dat er beperkingen zijn aan de autonomie van de aandeelhouders, wijst op de principiële vrijheid van laatstgenoemden om naar eigen inzicht over het bestaan van de rechtspersoon te beschikken. De aandeelhouder is in beginsel vrij om de activiteit die hij autonoom begonnen is op ieder moment te staken. ${ }^{152}$

Löwensteyn ${ }^{153}$ ziet een inherente beperking van de vrijheid van aandeelhouders in de omstandigheid dat hun verhouding tot de vennootschap slechts bepaald wordt door "hun belangen als winstgerechtigden." Ik kan echter niet inzien waarom, gegeven het instrumenteel karakter van de vennootschap, aandeelhouders q.q. geen andere belangen dan die als winstgerechtigden zouden mogen nastreven, zolang althans geen rechten van anderen worden geschonden. De Hoge Raad spreekt in het hiervoor aangehaald Wennex-arrest ${ }^{154}$ over een eigen belang van de aandeelhouder zonder verdere beperkingen. Hoewel het belang van de aandeelhouder doorgaans het behalen van winst zal zijn, is het niet ondenkbaar dat hij door middel van de vennootschap, direct of indirect, een ander belang nastreeft. Zo zal bijvoorbeeld de enig aandeelhouder van twee elkaar concurrerende vennootschappen één van de twee vennootschappen kunnen ontbinden om het voortbestaan van de andere te waarborgen; de overheid zal door middel van een vennootschap een op zich onrendabele activiteit omwille van het algemeen belang (dus anders dan als winstgerechtigde) kunnen laten uitoefenen, etc. De enige beperking die op de aandeelhouder rust bij de uitoefening van zijn rechten is het respect voor de rechten van

150. (...vervolg)

aandeelhoudersbelang, zoals dit mijns inziens principieel het geval dient te zijn, staat niet op voorhand vast dat onze standpunten in de praktijk tot dezelfde resultaten leiden.

151. Zie onder andere OK 21 juni 1979, NJ 1980, 71 (BATCO) met als uiteindelijk resultaat sluiting van de onderneming, OK 28 november 1991, NJ 1992, 201 en OK 7 juli 1988, NJ 1989, 845 (Fluke). Of de door de OK in deze gevallen gegeven motivering bevredigend is kan daar gelaten worden. Zie de noten van Maeijer in de NJ en de door hem aldaar genoemde auteurs.

152. De wetgever kan gemeend hebben dat het een verstandige maatregel is om ter bestrijding van lege vennootschappen de statutaire duurbeperking van alle rechtspersonen te verbieden (Wetsvoorstel 22482). Aan de principiële vrijheid van de aandeelhouders om de rechtspersoon te allen tijde te ontbinden doet deze betreurenswaardige afschaffing niet af. Overigens bestaan er andere middelen dan de statutaire duurbeperking om een rechtspersoon met heperkte levensduur tot stand te brengen. Zie hierover onder andere A.F. Klamer, WPNR 6071 (1992), blz. 875 e.v.

153. (1970), blz. 88 e.v.

154. HR 30 juni 1944 , NJ 1944, 465. 
derden. Met andere woorden, het door hem na te streven belang dient door de rechtsorde te worden beschermd.

Houdt men het bovenstaande in het oog, dan kan de uitspraak van de Hoge Raad in het Doetinchemse IJzergieterij-arrest ${ }^{155}$ tot juiste proporties worden teruggebracht. Ons hoogste rechtscollege stelt dat "commissarissen, rechten uitoefenende, die hun als orgaan der vennootschap zijn toegekend, zich hebben te richten naar het belang der vennootschap en dit moeten doen overwegen, indien dit naar hun oordeel in botsing komt met belangen van welken aandeelhouder dan ook." Bij de interpretatie van deze tot gemeenplaats verworden uitspraak is van toepassing het woord van Allen, dat "throughout the whole application of the law, the principles are primary and the precedents are secondary, and if we lose sight of this fact, the precedents become a bad master instead of a good servant. "156

De ratio decidendi van het arrest moet worden verstaan tegen de achtergrond van het betrokken geval. Het ging i.c. om een uitgifte van aandelen waarbij de grootste aandeelhouder zijn meerderheid zou verliezen. Uitgaande van het feit dat de uitgiftebevoegdheid bij de rvc berustte, dat wettelijk noch statutair aan aandeelhouders een voorkeursrecht toekwam en dat de emissie zakelijk geboden was en niet beoogde de rechten van de aandeelhouder te schaden, concludeert de Hoge Raad dat "de enkele omstandigheid" ${ }^{157}$ dat door de uitgifte de aandeelhouder zijn meerderheidspositie verliest, onvoldoende reden is om de vrijheid van handelen van de commissarissen te beperken, in dier voege dat de emissie in het belang van de aandeelhouder zou dienen te geschieden, of beter gezegd, dat de aandeelhouders gerechtigd zouden zijn tot de nieuwe aandelen. Meer moet in het arrest mijns inziens niet worden gelezen. De vrijheid van de rvc waarover de Hoge Raad spreekt is uit de aard der zaak bepaald door de omstandigheden van het geval. Bepalend is met name het feit dat aan de aandeelhouders geen voorkeursrecht toekwam. ${ }^{158}$ De overweging van de Hoge Raad geeft gezien de uitgangspunten van waaruit zij gedaan is en de beginselen van het toen geldende recht geen aanleiding om, zoals veelal in onze literatuur gebeurt, de vennootschap te beschouwen als een van de aandeelhouders feitelijk gescheiden entiteit die per definitie een ander belang heeft dan dat der aandeelhouders.

Beziet men andere uitspraken waarin het vennootschappelijk belang betrokken is, dan is de conclusie dat het probleem hoofdzakelijk betreft de

155. HR 1 april 1949, NJ 1949, 465.

156. C.K. Allen, Law in the making, 7th. ed. Oxford 1966, blz. 285.

157. Blz. 836, r.k. Zie ook de noot van Houwing onder het arrest.

158. Zie de kritische bespreking van het arrest door Van der Grinten, De NV 27 (194950), blz. 121. 
beperking van de zeggenschapsrechten van een of meer aandeelhouders, hetzij door andere aandeelhouders, hetzij door de leidinggevende organen. Voor zover niet het stemrecht van aandeelhouders betrokken is, gaat het er om vast te stellen aan wie het economisch voordeel van een transactie uiteindelijk dient toe te komen. Over het algemeen zullen de aandeelhouders de adressaten van dat voordeel dienen te zijn. Wie zulks betwist zal moeten aantonen waarom de aanspraak van de aandeelhouders niet gehonoreerd dient te worden.

De autonomie van oprichters en aandeelhouders om over de vennootschap te beschikken kan in onze dagen niet voldoende worden benadrukt. Het is dezelfde autonomie die de rechtsgenoten bezitten om contractuele verhoudingen aan te gaan en daaraan vorm te geven of om over hun vermogen na dode te beschikken. Deze autonomie ontplooit zich in een wisselwerking tussen lex et libertas. Dat de rechtsgenoten bij de verwezenlijking van deze autonomie zich zouden moeten laten leiden door de belangen van een van hen losstaand instituut en niet door hun rechtmatige belangen, lijkt mij niet in overeenstemming met de beginselen van onze rechtsorde. 


\section{HOOFDSTUK II}

\section{Bevoegdheden van de raad van commissarissen}

De aan de rvc toekomende bevoegdheden bepalen de positie van dit orgaan binnen de vennootschap. Door middel van de hem toegekende bevoegdheden oefent de raad zijn toezichthoudende taak uit. De inhoud van deze bevoegdheden is niet in alle vennootschappen gelijk. De wet maakt een belangrijk onderscheid tussen gewone en structuurvennootschappen. Daarnaast is de statutaire regeling van de betrokken vennootschap van belang. Wet en statuten bepalen de bevoegdheden van de rvc. In het structuurmodel is de toekenning van de bevoegdheden grotendeels dwingend in de wet geregeld. Slechts op onderdelen zijn statutaire aanvullingen toegestaan. Uit de aard van het dwingend recht vloeit voort dat de rechtsgenoten niet bevoegd zijn om statutair of contractueel anders te bepalen dan de wet voorschrijft (art. 3:40 BW). In het gewone model bestaat een ruimere vrijheid bij de toekenning -of onthouding- van bevoegdheden aan de rvc. Dit verschil tussen de twee vennootschapsmodellen is voor de rvc met name van belang waar het betreft zijn samenstelling en taakvervulling. ${ }^{1}$

Ondanks het verschil in toebedeling van bevoegdheden zullen in het onderhavige hoofdstuk, voor zover niet anders wordt aangegeven, beide vennootschapsmodellen zonder onderscheid worden behandeld. Het gaat hier immers om de bevoegdheden die aan de rvc toekomen. Dit betreft de vraag in hoeverre de rvc handelingen mag verrichten die voor de vennootschap bindend zijn. Bezien vanuit het perspectief van het bevoegd zijn, is het in beginsel niet van belang of, bijvoorbeeld, bepaalde bestuursbesluiten aan de goedkeuring van de rvc onderworpen zijn op grond van art. 164 of van een statutaire bepaling bij een gewone vennootschap.

Voor de hier gekozen aanpak pleit voorts dat ondanks het verschil in bevoegdheden gesproken kan worden van hetzelfde orgaan. Daar de gewone en de structuur rvc eenzelfde taakstelling binnen de rechtspersoon

1. Deze verschillen worden behandeld in hoofdstukken III en IV. 
hebben, kunnen zij tesamen besproken worden.

Tenslotte bestaat de meer praktische reden dat, behalve voor wat betreft de benoeming van commissarissen, doorgaans een grote parallellie bestaat tussen de bevoegdheden van de rvc in beide modellen. ${ }^{2}$

\section{§ 5. Raad van Commissarissen en Prioriteit}

Alvorens in te gaan op de afzonderlijke bevoegdheden van de rvc zou ik een preliminaire kwestie aan de orde willen stellen.

De taakvervulling van de rvc zou kunnen worden beïnvloed indien de uitoefening van de commissariële bevoegdheden afhankelijk zou kunnen worden gemaakt van de medewerking van een derde. Hierbij moet met name worden gedacht aan de vergadering van prioriteitsaandeelhouders. Prioriteitsrechten zijn een creatie van de oprichters/aandeelhouders. Gezien het dwingend karakter van een aantal bepalingen met betrekking tot de rvc, rijst de vraag in hoeverre de wettelijke regeling aangevuld of beperkt kan worden door middel van prioriteitsrechten.

De autonomie van de rechtsgenoten vindt haar grenzen in het dwingend recht, de openbare orde en de goede zeden (art. 3:40 BW). ${ }^{3}$ Daar de handelsgebruiken en het departement, met een zekere steun in het positieve recht (artt. 133 en 143), het bestaan van prioriteitsrechten hebben gesanctioneerd, is er geen sprake van strijd met de openbare orde of goede zeden. Waar het gaat om de verenigbaarheid met het dwingend recht zal het departement er slechts op toezien dat het orgaan waaraan commissariële bevoegdheden worden toegekend rvc heet en zulks ook is ( $\$ 6)$. Dit alles zegt echter op zich niets over de hier aan de orde zijnde problematiek, namelijk de geoorloofdheid van een facultatief orgaan dat zeggenschap heeft in de taakvervulling van de rvc.

In deze kwestie dient mijns inziens het uitgangspunt te zijn dat de wettelijke regeling de structuur van de vennootschap op dwingende wijze regelt (art 25). Naar mijn mening is er in het wettelijk systeem geen ruimte om de taakvervulling van een wettelijk orgaan te onderwerpen aan de medewerking van instanties die door de rechtsgenoten autonoom worden ingesteld. Op dezelfde manier als het bestuur het vennootschappelijk beleid zelfstandig dient te bepalen, dient de rvc de controle over dat beleid in vrijheid uit te oefenen. Voor zover het beleid door anderen dan bestuurders

2. Tenzij anders wordt aangegeven, beperk ik mij bij de bespreking van de structuurrvc tot vennootschappen waarop het volledige regime van toepassing is.

3. In gelijke zin, Cremers (1971), blz. 40, die zich op zijn beurt beroept op het Handboek, nr. 187.1 en op Dorhout Mees, Statuten van Naamlooze Vennootschappen, 1933, blz. 177 en 198. 
of commissarissen bepaald c.q. gecontroleerd wordt, zullen deze personen de desbetreffende verantwoordelijkheid dienen te dragen (art. 151 en $\S 6$ Dep. Richtl.). Rechtens zijn zij als bestuurders c.q. commissarissen te beschouwen.

De ongeoorloofdheid van de hier bestreden constellatie is met name zichtbaar wanneer het facultatieve orgaan zeggenschap heeft over de uitoefening van een bevoegdheid die de wet aan het wettelijke orgaan (i.c. de rvc) dwingend toekent. Ik geef een voorbeeld. Voor de vervulling van zijn taak is de rvc goeddeels aangewezen op informatie van het bestuur. Het bestuur is verplicht aan de rvc de voor diens taakvervulling noodzakelijke informatie te verschaffen (art. 141). Dit informatierecht kan mijns inziens niet op enigerlei wijze door de prioriteit worden aangetast. De statuten kunnen niet rechtsgeldig bepalen dat de prioriteit over de noodzakelijkheid van de informatie beslist, of dat het bestuur slechts in de aanwezigheid van de prioriteit de rvc mag informeren, omdat dan een facultatief orgaan zeggenschap zou verkrijgen in de wijze van uitoefening van een bevoegdheid die ex lege aan de rvc toekomt. De ongeoorloofdheid van het naast elkaar bestaan van prioriteit en rvc ligt, naar mijn mening, in het feit dat een zelfstandige taakuitoefening door de rvc in gevaar komt wanneer terzake van de toezichthoudende functie zeggenschap wordt gegeven aan anderen dan commissarissen. De wet kent aan de rvc zekere bevoegdheden toe met het oog op de controle door commissarissen van de leidinggevende taak van het bestuur. De uitoefening van deze bevoegdheden dient in vrijheid te geschieden omdat commissarissen daarvoor een eigen verantwoordelijkheid dragen. Het past niet in het systeem van de wet dat de rvc als wettelijk orgaan aangewezen zou zijn op de medewerking van een facultatief orgaan.

$\mathrm{Nu}$ zou men kunnen stellen dat het voorgaande slechts opgaat voor zover de vennootschap verplicht is een rvc in te stellen. Bij vennootschappen waarvoor het gewone regime geldt, zou het bestaan van prioriteitsrechten geen problemen opleveren omdat de rechtsgenoten vrij zijn in het al dan niet instellen van een controlerend college. Deze argumentatie lijkt mij niet correct omdat de autonomie van oprichters/aandeelhouders slechts onbeperkt is waar het betreft het al dan niet instellen van een rvc. Met betrekking tot de inhoud van de toezichthoudende taak is de autonomie echter beperkt. Zodra oprichters/aandeelhouders hebben besloten een toezichthoudend college in het leven te roepen, dient dit college een rvc te zijn die in staat is zijn taak in vrijheid uit te oefenen. Of de rvc zijn taak uitoefent bij een gewone dan wel bij een structuurvennootschap is in deze context niet van belang, omdat in beide gevallen met betrekking tot de 
taakuitoefening dezelfde wettelijke bepalingen gelden. ${ }^{4}$

Sprekend voorbeeld voor het hier verdedigde standpunt is het geval van het goedkeuringsrecht van commissarissen. Algemeen wordt aangenomen dat een dubbele goedkeuring door rvc en prioriteit geoorloofd is. ${ }^{s}$ Gesteld dat de goed te keuren besluiten dezelfde zijn bij een structuur- en bij een gewone vennootschap, is het enige verschil op dit punt de rechtsgrond van de commissariële goedkeuring. Terwijl bij structuurvennootschappen het goedkeuringsrecht een wettelijke basis heeft, komt dit recht aan de rvc van de gewone vennootschap toe krachtens statutaire bepaling. Het is echter niet in te zien waarom het enkele feit dat de goedkeuring van de rvc een wettelijke dan wel een statutaire grondslag heeft tot een ander oordeel zou moeten leiden waar het betreft de zelfstandigheid waarmee de rvc zijn taak dient uit te oefenen. Dat het goedkeuringsrecht in het structuurregime een wettelijke basis heeft, betekent dat de rechtsgenoten niet vrij zijn om de rvc dat recht te onthouden. Dat hetzelfde recht in het gewone regime een statutaire basis heeft, wil naar mijn mening zeggen dat oprichters/aandeelhouders het in hun macht hebben de rvc al dan niet dat recht toe te kennen, maar niet dat zij aan derden zeggenschap zouden kunnen geven in de taakvervulling van commissarissen.

De goedkeuring van bestuursbesluiten dient te worden gezien als een uitvloeisel van de toezichthoudende taak. ${ }^{6}$ De onverenigbaarheid van een dubbele goedkeuring met het wettelijk systeem bestaat hierin dat indien de goed- dan wel afkeuring van de rvc door de prioriteit (of door een ander) zou worden tegengesproken, de vennootschap een beleid zou voeren dat contrair is aan hetgeen de rvc in het belang van de vennootschap raadzaam acht. Zulks verdraagt zich niet met de exclusiviteit die aan de rvc toekomt ten opzichte van het toezicht op dat beleid. Hiermee wordt niet ontkend dat het onder omstandigheden wenselijk kan zijn een ander orgaan naast de

4. Zie hiervoor $\& 1, \mathrm{IV}$.

5. Met verschillende nuances achten Uniken Venema, (1970), blz. 143; Slagter (1990), blz. 313; Sanders / Westbroek (1991), blz. 212; Van Schilfgaarde (1992), nr. 144 en het Departement, Dep. Richtl. $\$ 14$, dit geoorloofd zowel bij structuurals bij gewone vennootschappen. Voor Cremers (1971), blz. 151-152; Maeijer (1973), blz. 25-26 en Timmerman, Rechtspersonen, art. 164, aant. 4, zijn de onderhavige prioriteitsrechten niet verenigbaar met het structururregime, althans voor zover het betreft de besluiten genoemd in art. 164 .

6. Maeijer, Wetsgeschiedenis, IXf, Art. $52 n$ (III) - 2: "Door deze besluiten onder controle van de raad van commissarissen te brengen, schept men grotere waarborgen voor een evenwichtige belangenafweging, die immers juist mede tot de taak van de commissarissen behoort. Aan de andere kant worden commissarissen daardoor ook nauwer bij het ondernemingsbeleid betrokken en met grotere verantwoordelijkheid belast" (curs. van mij JMBF). Zie ook Uniken Venema (1970), blz. 146. 
(structuur)rvc in te stellen, bijvoorbeeld ondat zulks "extra-waarborgen" biedt voor een zorgvuldige besluitvorming. ${ }^{7}$ Om deze waarborgen te introduceren kan men een adviserend college vormen, maar aan een dergelijk college kunnen geen controlerende bevoegdheden met betrekking tot het beleid worden toegekend nu zulks behoort tot de exclusieve competentie van de rvc.

De onverenigbaarheid van de prioriteit met de rvc waar het gaat om de uitoefening van de toezichthoudende taak blijkt ten slotte uit de verschillende aard van beide organen. Terwijl de rvc een orgaan is met een door de wet geregelde positie binnen de vennootschap, is de prioriteit een facultatief, niet wttelijk geregeld orgaan met zekere bevoegdheden die tot de bevoegdheidssfeer van de algemene vergadering behoren. Commissarissen zijn bij de uitoefening van hun bevoegdheden gebonden aan de instructienorm van art. 140 en dragen daarvoor een eigen verantwoordelijkheid. Daarentegen wordt de uitoefening van de bevoegdheden van de prioriteit bepaald door het doel waarvoor dit orgaan in het leven is geroepen. De leden van de prioriteit hoeven niet onder alle omstandigheden verantwoordelijkheid te dragen voor het gevoerde beleid. ${ }^{8}$

Het voorgaande wil niet zeggen dat prioriteit en rvc per definitie onverenigbaar zijn. Voor zover aan de controlerende taak van de rvc vorm kan worden gegeven, kunnen de oprichters/aandeelhouders terzake van die aangelegenheden zeggenschap geven aan de prioriteit. Zolang de rvc vrij is in de uitoefening van de hem toekomende bevoegdheden zal de vervulling van zijn taak niet worden doorkruist. Aan de prioriteit kunnen bijvoorbeeld goedkeuringsrechten worden toegekend met betrekking tot andere besluiten dan die welke aan de goedkeuring van de rvc zijn onderworpen. In ieder concreet geval zal dienen te worden beoordeeld in hoeverre, gezien de toebedeling van bevoegdheden, een zelfstandige taakvervulling door de rvc mogelijk is.

7. Zo Uniken Venema (1970), blz. 143, met een beroep op de hiervoor aangehaalde passage van de MvT. Anders echter Timmerman, Rechtspersonen, art. 164, aant. 4 , met eenzelfde beroep.

8. Naar de mening van Cremers (1970), blz, 158, zijn prioriteitsaandeelhouders "niet (...) verantwoording schuldig voor de uitoefening van hun bevoegdheden." Dit is mijns inziens in strijd met de opvatting van schrijver dat het veanootschappelijk belang voor deze aandeethouders richtinggevend is (t.a.p., blz. 95 en 152). Ook Uniken Venema (1970), blz. 134, verwerpt een verantwoordingsplicht van de prioriteitsaandeelhouders. 


\section{§ 6. Benoeming en schorsing van commissarissen. Verwijzing}

In het structuurregime komt aan de rvc de bevoegdheid toe om de commissarissen te benoemen en te schorsen (art. 158 en 161 lid 3). ${ }^{9}$ Voorts is de structuur-rvc bevoegd om de vennootschap te vertegenwoordigen bij het indienen van een verzoek tot ontslag van een commissaris (art. 161 lid 2). Het belang van de coöptatiebevoegdheid ligt voornamelijk hierin dat de rvc het bestuursorgaan benoemt. De samenstelling van het college van commissarissen kan indirect van groot belang zijn voor de samenstelling van het bestuur.

De wettelijke regeling van de benoemingshevoegdheid draagt de sporen van een moeizaam bereikt compromis. ${ }^{10}$ Ik zal deze bevoegdheid bespreken tegen de achtergrond van de samenstelling van de rvc (Hoofdstuk III hierna). In dat verband zullen ook andere onderwerpen behandeld worden die met de benoemingsbevoegdheid samenhangen, zoals de benoemingsprocedure en de rechtspositie van de commissaris.

Hoewel deze overwegingen met name gelden voor structuurvennootschappen, behandel ik de benoemingsbevoegdheid bij gewone vennootschappen eveneens in het kader van de samenstelling van de rvc. Ik verwijs daarvoor ook naar het volgende hoofdstuk.

\section{\$ 7. Benoeming, schorsing en ontslag van bestuurders}

In het volledige structuurregime worden de leden van het bestuur door de rve benoemd, geschorst en ontslagen (artt. 162 en 134). De benoemingsbevoegdheid kan eveneens toekomen aan de rvc bij vennootschappen die het structuurregime vrijwillig hebben aangenomen (art. 157 lid 1). Deze benoemings- en ontslagbevoegdheid geeft aan de rvc een centrale positie binnen de vennootschap. De macht om de bestuurders te benoemen en te ontslaan stelt de instantie aan wie deze macht toekomt in zekere zin in staat om het beleid van de vennootschap te bepalen. Immers, in de beschikking over de ambten van de beleidsbepalers ligt feitelijk de mogelijkheid besloten om over dat beleid te beslissen. Dit is te meer het geval wanneer, zoals in onze wet, het ontslag van de beleidsbepalers te allen tijde kan worden verleend. De positie van de rvc in het structuurregime wordt verder versterkt doordat commissarissen onafhankelijk zijn van de algemene vergadering, in dier voege dat de ava niet de macht heeft om over de

9. De benoemingsbevoegdheid komt onder bijzondere omstandigheden an anderen dan de rve toe. Vgl. artt. 158 leden 2 en 12, 159 en 356.

10. Het wordingsproces is beschreven door G.H.A. Schut, Het wonder van Den Haag, Verdam-bundel, Deventer 1971, blz. 307 e.v. 


\section{BENOEMING VAN BESTUURDERS}

commissariële ambten te disponeren.

De beslissing van de wetgever om de benoemingsbevoegdheid toe te kennen aan de rvc berust hoofdzakelijk op twee overwegingen. In de eerste plaats hebben de ontwerpers van het systeem" ${ }^{11}$ beoogd het oligarchisch karakter van de grote vennootschap wettelijk te sanctioneren en daarmee het gebruik van oligarchische clausules, die geen afdoende wettelijke regeling genoten, enigszins te beperken. Voorts heeft de wetgever via de rvc de medezeggenschap van de werknemers ook op bestuursniveau willen te laten doorwerken.

Toekenning van de bevoegdheid tot benoeming van bestuurders aan de rvc en invoering van het coöptatiesysteem voor de benoeming van commissarissen passen in het beeld van een vennootschap waarin de leidinggevende organen de facto onafhankelijk zijn van de aandeelhouders. ${ }^{12}$ Dit beeld stond ook de ontwerpers van het structuurregime voor ogen. Het komt mij echter voor dat de vennootschappelijke verhoudingen in de praktijk niet steeds overeenkomen met de voorstellingen van de wetgever. Wellicht kan zelfs worden gesteld dat de vennootschappen waarin de leidinggevende organen daadwerkelijk onafhankelijk zijn van de aandeelhouders, eerder uitzondering zijn dan regel, ook in het geval van structuurvennootschappen. Zodanige onafhankelijkheid bestaat immers slechts indien alle aandeelhouders een te verwaarlozen kapitaalparticipatie bezitten. Waar een of meer aandeelhouders een substantiële participatie hebben zal doorgaans van feitelijke onafhankelijkheid geen sprake zijn. ${ }^{13}$ Mijns inziens wordt hiermee onvoldoende rekening gehouden wanneer, bijvoorbeeld ter

11. Zie de toelichting op het door de Commissie Verdam opgestelde art. 50h (WvK), dat de voorloper is geweest van het huidige art. 162, (Herziening van het ondernemingsrecht, "s-Gravenhage 1965, hlz. 124) en het advies van de SER d.d. 19 september 1969, inzake de herziening van het ondernemingsrecht, uitgave van de SER ar. 14, blz. 12 e.v.

12. Deze evolutie is onder andere beschreven in de klassieke studie van $R$. Wiethoher, Interessen und Organisation der Aktiengesellschaft, Karlsruhe 1961. Vgl. hierover in Nederland, W.J. Slagter, Macht en onmacht van de aandeelhouder, Rede Rotterdam 1988, blz. 5 e.v. Twee kenmerkende stadia in deze evolutie zijn art. 31 Code de Commerce (1807) ("Elle [de société anonyme, JMBF] est administrée par de mandataires à temps, révocables, associés ou non associés, salariés ou gratuits") en $\$ 70$ AktG 1937 ("Der Vorstand hat unter eigener Verantwortung die Gesellschaft so zu leiten, wie das Wohl des Betriebes und seiner Gefolgschaft und der gemeine Nutzen von Volk und Reich es fordern").

13. Wat een substantiele participatie is, kan niet in het algemeen worden gesteld. Zulks hangt met name af van de verspreiding van het aandelenkapitaal. Uit verschillende publikaties blijkt dat slechts in zeer weinig Nederlandse beursvennootschappen geen dominerende aandeelhouder(sgroep) bestaat. Vgl. bijvoorbeeld NRC-Handelsblad 24 oktober 1990 en Het Financiële Dagblad 19 november 1991, De Omzetcijfers van 1990. 
afwering van de invloed van een groot aandeelhouder in de leidinggevende organen, gesteld wordt dat bestuur en commissarissen onafhankelijk zijn van de aandeelhouders. Dat rechtens zulks het geval is blijkt uit de wet. Maar de juridische onafhankelijkheid van bestuur en rvc ten opzichte van aandeelhouders is in zoverre betrekkelijk, dat in een vennootschap, waarin een aandeelhouder(sgroep) een substantiële deelneming heeft, het vennootschappelijk belang in belangrijke mate bepaald wordt door het belang van die aandeelhouder. Aandeelhouders van een structuurvennootschap kunnen aan het enkel aandeelhouderschap weliswaar geen recht tot benoeming van bestuurders of commissarissen ontlenen. Het ontbreken van een zodanig benoemingsrecht is niet in strijd met het wezen van de vennootschap als kapitaalassociatie omdat, hoewel de vennootschap doorgaans gericht is op de realisatie van winst ten behoeve van de personen die risicodragend kapitaal ter beschikking hebben gesteld, deze terbeschikkingstelling van kapitaal niet de macht behoeft in te houden om over de leidinggevende ambten te beschikken. Maar het wezen van de vennootschap zou wel worden miskend wanneer het benoemings- en ontslagbeleid van commissarissen met betrekking tot bestuurders onvoldoende oog zou hebben voor de belangen van de aandeelhouders.

\section{Benoeming van bestuurders}

Benoeming is een rechtshandeling van rechtspersonenrechtelijke aard waarbij het bevoegde orgaan van de vennootschap een bepaalde persoon aanwijst om het bestuurdersambt te bekleden. Benoeming vindt plaats krachtens besluit. Echter, niet het besluit bewerkstelligt de benoeming. Deze komt tot stand door de aanvaarding door de kandidaat van het tot hem gerichte aanbod. Onderscheid dient dan ook gemaakt te worden tussen het benoemingsbesluit, dat een interne vennootschapsrechtelijke handeling is, de verklaring van de vennootschap waarbij het aanbod tot benoeming wordt gedaan en de aanvaarding van dit aanbod. Niet ondenkbaar is dat al deze handelingen feitelijk samenvallen, bijvoorbeeld indien benoeming plaats vindt in een vergadering waar de kandidaat aanwezig of vertegenwoordigd is.

Aanvaarding van het aanbod tot benoeming is mijns inziens een rechtshandeling sui generis, waarbij de kandidaat verklaart het bestuurdersambt te willen aanvaarden. Aanvaarding van de benoeming houdt in de bereidverklaring om zekere vennootschappelijke bevoegdheden uit te oefenen. Een dergelijke handeling is, naar mijn mening, niet een overeen- 
komst in de zin van Boek $6 \mathrm{BW} .{ }^{14}$ Ook de rechtspositie van de bestuurder in de vennootschap, die krachtens benoeming ontstaat, is niet van contractuele aard. ${ }^{15}$

De hier verdedigde visie wordt met name bestreden door Van der Grinten. Volgens deze schrijver wordt "de bestuurder (...) bestuurder van de rechtspersoon door een tweezijdige rechtshandeling tussen de rechtspersoon en hem. Er zijn onvoldoende termen om deze tweezijdige rechtshandeling niet als overeenkomst te kwalificeren. De omstandigheid dat rechten en verplichtingen van partijen bij de rechtshandeling geheel of goeddeels door de wet en de statuten van de rechtspersoon worden bepaald, brengt niet mede dat er niet een contractuele relatie zou zijn." ${ }^{16}$ Of de rechtshandeling waarbij de bestuurder deze hoedanigheid verkrijgt als een overeenkomst moet worden beschouwd, behoeft hier geen nadere analyse. In ieder geval zal de term overeenkomst in de zeer ruime betekenis van 'wilsovereenstemming' moeten worden verstaan. ${ }^{17}$ De betekenis van deze aanduiding is dan beperkt. Maar wanneer de verhouding tussen bestuurder en vennootschap, die een gevolg is van de aanvaarding van het benoemingsaanbod, als overeenkomst wordt aangemerkt, wordt daarmee de eigen aard van de verhouding mijns inziens miskend. Dit eigen karakter wordt, zoals Van der Grinten terecht stelt, niet bepaald door het feit dat de verhouding door wet en statuten wordt beheerst. Immers, ook een niet door partijen autonoom gestelde regeling kan de inhoud van hun contractuele relatie bepalen, zolang de gelding van de regeling aanvaard is (bijvoorbeeld, de huwelijksovereenkomst). Op dit punt geldt echter hetgeen Van der Grinten zelf stelt ten opzichte van de lidmaatschapsverhouding van de oprichters van de vereniging tot de opgerichte rechtspersoon: "Ook indien men aanneemt dat het aangaan van een lidmaatschapsverhouding een overeenkomst is, sluit dit niet noodzakelijk in dat de lidmaatschapsverhouding een

14. Vgl. in het Duits recht Staudinger-Coing, \&27 Rz 10: "Erforderlich ist jedoch, daß der Bestellte die Bestellung annimmt; hierin ist aber nicht die Annahme einer Vertragsofferte zu sehen. Es handelt sich vielmehr um eine Rechtsbedingung. So jetzt hL."

15. Over de rechtspositie van de bestuurder vgl. Flume (1983), blz. 345 e.v. In de Nederlandse literatuur wordt de eigen aard van het bestuurderschap enigszins aanvaard door Kamphuisen, De NV 25 (1947-48), Verzameld Werk, Zwolle 1966, blz. 485 e.v. Schrijver spreekt over een relatie waarop twee normencomplexen worden toegepast, namelijk vennootschapsrecht en overeenkomstenrecht en waarbij het vennootschapsrecht als lex specialis voorrang heeft (t.a.p., blz. 494). De eigen aard van de verhouding wordt wel onderkend in een artikel over de positie van de commissaris, De NV 21 (1943-44), Verzameld Werk, blz. 471 e.v. Mijns inziens correct ook Huizink (1989), blz. 9.

16. Asser-Van der Grinten II, nr. 42.

17. Zo kennelijk Huizink (1989), blz. 7. 
contractuele betrekking is. ${ }^{18}$ Op dezelfde manier als de verhouding van aandeelhouder/lid tot de rechtspersoon niet een contractuele verhouding is, is het bestuurderschap niet een verhouding van contractuele aard tussen bestuurder en de door hem bestuurde rechtspersoon. De positie van de bestuurder in de vennootschap is een organieke, niet een contractuele. Het wezen van het orgaan wordt niet bepaald door het feit dat het gericht is op het tot stand brengen van verbintenissen tussen de rechtspersoon en de bestuurder, doch op de verwerkelijking van de rechtspersoon door de orgaanbemanner. De betrokken ambtsdrager vervult een bepaalde taak binnen de rechtspersoon. De taakvervulling houdt in uitoefening van vennootschappelijke bevoegdheden. Dat de bestuurder krachtens autonome beslissing tot de rechtspersoon toetreedt, en dat de aard van de verhouding op sommige punten analogie vertoont met contractuele figuren zoals de overeenkomst tot het verrichten van enkele diensten, is onvoldoende reden om te stellen dat de rechtspersonenrechtelijke verhoudingen contractueel van aard zijn. ${ }^{19}$

Aan het voorgaande doet niet af dat naast de vennootschapsrechtelijke bestuursrelatie mogelijk een andere relatie van contractuele aard tussen bestuurder en vennootschap bestaat. In de praktijk zal benoeming als bestuurder gepaard kunnen gaan met aanstelling als werknemer in dienst van de vennootschap. ${ }^{20}$ Hoewel de feitelijke werkzaamheden waartoe bestuurderschap en werknemerschap verplichten gelijk kunnen zijn, dient tussen beide rechtsverhoudingen te worden onderscheiden. Rechtens zijn de twee rechtsverhoudingen twee verschillende realiteiten. Hun ontstaan en voortbestaan zijn aan verschillende normen onderworpen.

Het door Kamphuisen ${ }^{21}$ verdedigde standpunt "dat er slechts één rechtsbetrekking bestaat (...), ook al zijn daarop twee normencomplexen van toepassing" verklaart de gecompliceerde rechtspositie van de bestuurder/werknemer niet. In hoeverre een of meer rechtsbetrekkingen aanwezig zijn, dient vanuit de rechtsorde te worden verklaard. Het bestaan van een pluraliteit van rechtsverhoudingen houdt in dat de rechtsorde meerdere rechtsbanden aanwezig acht in een bepaalde feitelijke verhouding. ${ }^{22}$

18. Asser-Van der Grinten II, nr. 235. Curs. ook in het origineel.

19. Vgl. \& 27 Abs. 3 BGB: "Auf die Geschäftsführung des Vorstandes finden die für den Auftrag geltenden Vorschriften det $\$ \$ 664$ bis 670 entsprechende Anwendung."

20. Noodzakelijk is zulks niet. Men denke aan de werknemer die als bestuurder van een dochtervennootschap wordt benoemd. Van enige contractuele verhouding van bestuurder jegens de dochter is dan mijns inziens geen sprake.

21. De NV 25 (1847-48), Verzameld Werk, blz. 494.

22. Vgl. Larenz (1989), blz. 194, alsmede de treffende opmerkingen van $F$, de Castro y Brawo, Derecho Civil de España, Madrid 1949 (herdruk 1984), blz. 552 e.v. 
Wanneer meerdere normencomplexen, dat wil zeggen meerdere groepen van normen die door verschillende beginselen worden beheerst, op eenzelfde feit van toepassing zijn, zal moeten worden aangenomen dat er een pluraliteit van rechtsverhoudingen anwezig is. Dat in ons recht de positie van de bestuurder/werknemer het bestaan van twee afzonderlijke rechtsverhoudingen impliceert blijkt met name in geval van conflicterende normen. Hierbij kan worden gedacht aan bepalingen omtrent de beëindiging van de rechtsverhoudingen ${ }^{23}$, maar ook aan collisie van rechtsnormen in IPR-verhoudingen. In laatstgenoemd geval kunnen de vennootschapsrechtelijke en de arbeidsrechtelijke verhouding des te duidelijker worden onderscheiden wanneer iedere verhouding door een verschillend rechtsstelsel wordt beheerst: de eerste door dat van het vennootschapsstatuut en de tweede door het door partijen aangewezen recht (artt. 3 en 6 EVO) ${ }^{24}$

De benoemingsbevoegdheid van de rvc kan niet door enige bindende voordracht worden beperkt (art. 162). Dit brengt mede dat de rvc zelfstandig dient te oordelen over de te benoemen kandidaat en dat het benoemingsbesluit van de raad tot stand dient te komen zonder externe bindingen. Zelfstandige oordeelsvorming impliceert echter niet, zoals hiervoor gesteld is, dat de rvc niet gebonden is aan de rechtmatige belangen van de aandeelhouders. Het benoemingsbeleid kan slechts van geval tot geval worden beoordeeld omdat de aandeelhouders terzake van de benoeming geen concrete aanspraak aan de wet kunnen ontlenen. De wet legt op dit punt de volle verantwoordelijkheid bij de rvc.

De vrijheid van handelen van de rvc zou kunnen worden beperkt door middel van statutaire bepalingen, volgens welke benoemingsbesluiten met een versterkte meerderheid van stemmen in de rvc zouden moeten worden genomen ${ }^{25}$, of volgens welke het besluit slechts zou kunnen worden genomen wanneer éen of meer aangewezen commissarissen (bijvoorbeeld de voorzitter) aanwezig zouden zijn. Met Maeijer ${ }^{26}$ acht ik deze beperkingen van de beslissingsvrijheid van de rvc ongeoorloofd, aangezien daarmee aan een derde (namelijk, de ava als orgaan dat de statuten bepaalt) zeggenschap

23. Zie hierna $\$ 7$, III.

24. Onjuist lijkt mij dan ook het standpunt van Schwarz (NJB 1982, blz. 328 e.v. en S\&V 1993, blz, 57 e.v.), die de rechtsverhouding van een op arbeidsovereenkomst werkzame verenigingshestuurder tot de vereniging als een 'gemengde overeenkomst' beschouwt. Van een gemengde overeenkomst in de zin van art. 6:215 BW kan reeds hierom geen sprake zijn, omdat het i.c. niet gaat om "twee of meer door de wet geregelde bijzondere soorten van overeenkomsten" (art. 215), doch om een contractuele relatie en een relatie van vennootschapsrechtelijke aard.

25. Zo Handboek, nr. 247.

26. (1973), blz. 22. 
wordt gegeven in de wijze van uitoefening van een bevoegdheid die aan de rvc dwingend en exclusief toekomt. Deze bepalingen lijken mij wel geoorloofd indien de rvc zelf in een door hem opgesteld reglement zulks beschikt. In dat geval regelt de rve de uitoefening van de benoemingsbevoegdheid op zelfstandige wijze. Als enige beperking geldt hierbij dat de bepalingen niet in strijd mogen zijn met de vennootschappelijke orde. ${ }^{27}$

Het departement ${ }^{28}$ laat zich niet expressis verbis uit over de toelaatbaarheid van statutaire kwaliteitseisen voor bestuurders van structuurvennootschappen. Bij gewone vennootschappen zijn zij wel toelaatbaar ( $\$ 6$ Dep. Richtl.). Volgens $\S 14$ is het bepaalde in $\S 6$ ook van toepassing op structuurvennootschappen, voor zover de wet zich niet daartegen verzet. Uit het hiervoor gestelde volgt dat mijns inziens de wet zich wel verzet tegen het stellen van statutaire kwaliteitseisen. Maeijer ziet dit kennelijk anders als hij schrijft dat "ten aanzien van bestuurders kwaliteitseisen functioneel [kunnen] zijn: in het belang van de vennootschap. ${ }^{129}$ Dat kwaliteitseisen in het belang van de vennootschap kunnen zijn, kan niet worden ontkend. Ook zonder zulke eisen zullen de benoemingen in het belang van de vennootschap moeten geschieden (art. 140). Maar omdat de rvc in vrijheid moet besluiten, is het mijns inziens in strijd met de wet dat de ava, door middel van een statutaire voorziening, de keuzevrijheid van commissarissen beperkt. De rvc draagt de volle verantwoordelijkheid voor de benoeming. Alleen dit orgaan is dan ook bevoegd om eisen te stellen waaraan de te benoemen bestuurders dienen te voldoen.

De rvc moet de ava in kennis stellen van een voorgenomen benoeming (art. 162). De status van deze mededeling is onduidelijk. De geldigheid van het benoemingsbesluit is volgens Van der Grinten niet afhankelijk van de kennisgeving. ${ }^{30}$ Daarentegen acht hij ${ }^{31}$ een ontslagbesluit van de rvc zonder raadpleging van de ava (art. 162) vernietigbaar wegens niet-naleving van de wettelijke procedureregels. Van der Grinten motiveert dit verschil in rechtsgevolg door te stellen dat bij benoeming de wet niet voorschrijft dat de ava gehoord dient te worden, terwijl in geval van ontslag art. 162

27. Geoorloofd lijkt mij de reglementaire bepaling dat het benoemingshesluit door de rvc met algemene stemmen dient te worden genomen. Ongeoorloofd zou ik echter de toekenning van een vetorecht aan én of meer commissarissen achten. De dwingende toedeling van de benoemingsbevoegdheid aan de raad als orgaan verzet zich mijns inziens tegen toekenning van bijzondere rechten aan een of meer leden van de raad.

28. Dep. Richtl. $\$ 14$.

29. (1973), blz. 22.

30. Handboek, nr. 247.

31. Handboek, nr. 254. 
bepaalt: de rvc "ontslaat een bestuurder niet dan nadat de algemene vergadering over het voorgenomen ontslag is gehoord." Andere schrijvers zijn van mening dat het ontbreken van de kennisgeving de geldigheid van het benoemingsbesluit aantast. ${ }^{32}$ Ik denk dat in deze de visie van Van der Grinten de juiste is. De wet spreekt weliswaar van het mededelen van "een voorgenomen benoeming". Deze uitdrukking zou tot de gedachte kunnen leiden dat zonder mededeling aan de algemene vergadering het besluit rechtskracht mist, althans vernietigbaar is. Het lijkt mij echter dat deze lezing niet correct is omdat in het systeem van de wet de mededeling op zich, anders dan bij ontslag, waar de ava gehoord dient te worden, geen gevolg heeft ten aanzien van het besluit. De wet bevat mijns inziens slechts een gebod aan de rvc om de voorgenomen benoeming aan de algemene vergadering mede te delen. De rvc handelt in strijd met de wet indien kennisgeving achterwege blijft, maar het benoemingsbesluit lijkt mij perfect te zijn vanaf het moment waarop het genomen is.

De bestuurder van de vennootschap kan tevens bestuurder van de onderneming zijn in de zin van art. 30 WOR. In dit geval dient de ondernemer de vennootschap- de or in de gelegenheid te stellen over de voorgenomen benoeming advies uit te brengen. Bij schending van deze plicht kan de or zich tot de kantonrechter wenden om nakoming daarvan te vorderen (art. 36 lid 2 WOR). De verplichting tot adviesaanvrage rust niet op de rvc, doch op het bestuur als vertegenwoordiger van de vennootschap. ${ }^{33}$

Een zwakke schakel in de wettelijke regeling is de vaststelling van de bezoldiging van bestuurders. Dit is een bevoegdheid die aan de ava toekomt voor zover de statuten niet anders bepalen (art. 135). Terecht merkt Slagter $^{34}$ op dat het weinig zin heeft de vitsluitende bevoegdheid tot benoeming (en ontslag) aan de rvc toe te kennen indien de permanentie in het ambt de facto ongedaan kan worden gemaakt door middel van een salarisverlaging. Een dergelijk besluit lijkt mij, wanneer de salarisverlaging slechts beoogt de betrokken bestuurder tot aftreden te dwingen, in strijd met de vennootschappelijke orde omdat de autonome uitoefening van de ontslagbevoegdheid van de rvc doorbroken wordt. Het bewijs van het onzuivere oogmerk bij de besluitvorming kan echter onder omstandigheden moeilijk te leveren zijn. Hoe dit ook zij, toewijzing aan de rvc van de bevoegdheden inzake bezoldiging van bestuurders lijkt het meest in overeenstemming met het wettelijk systeem. Alsdan is de rvc exclusief bevoegd om

32. Timmerman, Rechtspersonen, art. 162, aant. 2 (benoeming is ongeldig); Van Schilfgaarde (1992), nr. 144 (benoeming is nietig).

33. Nader over dit onderwerp Huizink (1989), blz. 88 e.v.

34. (1990), blz. 308 . 
te beslissen over een aangelegenheid die van belang is voor de rechtspositie van de bestuurders. ${ }^{35}$

\section{Schorsing van bestuurders}

Schorsing is een handeling van vennootschapsrechtelijke aard die tot doel heeft de uitoefening van de aan een ambt verbonden bevoegdheden tijdelijk te beletten. ${ }^{36}$ Schorsing kan omvatten het geheel of een deel der bevoegdheden. In beide gevallen is het resultaat dat de geschorste persoon de betrokken bevoegdheden niet kan uitoefenen en derhalve ook (gedeeltelijk) niet in staat is zijn taak te vervullen.

De wet regelt de schorsing van bestuurders in de artt. 134 en 147. Volgens art. 134 berust de bevoegdheid tot schorsing bij het orgaan dat tot benoeming van de bestuurders bevoegd is. Het artikel geldt zowel voor gewone als voor structuurvennootschappen. Bij structuurvennootschappen is dus de rvc tot schorsing bevoegd. Uit het systeem van de wet volgt dat deze bevoegdheid privatief is, zodat andere organen hierover geen zeggenschap hebben.

Art. 147 is van toepassing op gewone vennootschappen waarin een rvc is ingesteld. Het artikel kent aan de rvc de bevoegdheid tot schorsing toe voor zover de statuten niet anders bepalen (lid 1), met dien verstande dat de ava de schorsing te allen tijde kan opheffen (lid 2).

Ook ten aanzien van schorsing rijst de vraag of een nadere statutaire regeling van de schorsingsbevoegdheid van de rvc mogelijk is. Voor zover de rvc met uitsluiting van andere organen terzake competent is, acht ik een statutaire regeling om de hiervoor gegeven redenen niet geoorloofd. ${ }^{37}$

Schorsing en ontslag kunnen volgens art. 134 "te allen tijde" worden verleend. Met betrekking tot het ontslag, wordt algemeen aanvaard dat deze bepaling een discretionaire bevoegdheid inhoudt, waardoor het ontslag verleend kan worden zonder dat een dringende reden aanwezig is. ${ }^{38}$ Ten aanzien van schorsing wordt echter aangenomen dat deze maatregel wel de aanwezigheid van een deugdelijke grond veronderstelt. Hiervoor worden verschillende argumenten aangedragen. Gesteld wordt dat bij afwezigheid van voldoende grond het schorsingsbesluit in strijd is met redelijkheid en

35. In deze zin $\$ 87 \mathrm{AktG}$.

36. Vgl. Handboek, nr. 253.

37. Anders Handboek, nr, 253. Een quorumeis is volgens Von der Grinten toelaatbaar omdat de wet een dergelijke eis niet verbiedt.

38. Zie hierna $\$ 7$,III. 
billijkheid. ${ }^{39}$ Waarin echter de strijdigheid met redelijkheid en billijkheid zou bestaan wordt, voor zover ik kan zien, niet aangegeven. Vanzelf spreekt dat het schorsingsbesluit, zoals ieder ander besluit, aan de eisen van redelijkheid en billijkheid dient te voldoen. Doch dit zal aldus moeten worden verstaan dat schorsing niet mag plaatsvinden met het uitsluitend oogmerk om de geschorste bestuurder te benadelen, of anderszins misbruikt mag worden (art. 3:13 BW). Voorts is het mogelijk dat de leden van het schorsend orgaan een onrechtmatige daad begaan jegens de geschorste persoon indien zij meewerken aan de totstandkoming van een lichtzinnig genomen schorsingsbesluit. ${ }^{40}$ Maar zulks brengt niet mede dat schorsing op een zakelijke rechtvaardiging dient te berusten. Indien de wet het bevoegde orgaan de schorsingsbevoegdheid "te allen tijde" laat uitoefenen, houdt zulks in dat schorsing een discretionaire bevoegdheid is waarvoor, uit haar aard, in ons recht geen bijzondere rechtvaardiging behoeft te bestaan. Wanneer dan ook in de lagere rechtspraak overwogen wordt dat schorsing "te zwaar" of "disproportioneel"42 kan zijn, wordt daarmee aan deze maatregel een inhoudelijke eis gesteld die mijns inziens de wet niet stelt. Omdat schorsing niet afhankelijk is van een rechtvaardigende omstandigheid, kan niet over de "zwaarte" of de "proportionaliteit" van de maatregel worden gesproken. Op dezelfde manier als de algemene vergadering "te allen tijde" de schorsing kan opheffen (art. 147), kan zij, c.q. de rvc, ook "te allen tijde" tot schorsing overgaan. Op dit punt komt aan het schorsend orgaan eenzelfde vrijheid toe als aan de ava bij intrekking van de opdracht tot controle van de jaarrekening (art. 393 lid 2). De ava is ook daar "te allen tijde" bevoegd de aan de accountant verstrekte opdracht in te trekken. Het feit dat de accountant het recht heeft te worden gehoord alvorens de ava tot intrekking overgaat, beperkt de beslissingsvrijheid van de vergadering niet. ${ }^{43}$

Huizink $^{4}$, hoewel wijzend op de gelijkluidende wettelijke regeling $^{45}$, maakt op dit punt onderscheid tussen schorsing en ontslag. Volgens hem is voor schorsing, anders dan voor ontslag, de aanwezigheid van een deugdelijke grond noodzakelijk. "Het grote verschil tussen ontslag en schorsing is dat het eerste gericht is op beëindiging van de rechtsbetrekking en het tweede juist niet", zo wordt gesteld. lk zou echter menen dat uit het

39. Asser-Van der Grinten II, nr. 339; Lowensteyn, Rechtspersonen, art. 134, aant. 5. Zie ook Handboek, nr. 253.

40. Zo HR 22 december 1961 , NJ 1962,43 (Ariëns/Van de Loo).

41. Pres. Rb. Haarlem 17 december 1991, KG 1992, 38 (r.o. 3.13).

42. Pres. Rb. Arnhem 14 juli 1992, KG 1992, 363.

43. In gelijke zin IJsselmuiden, Rechtspersonen, art. 393, aant. 3.

44. (1989), blz. 86.

45. (1989), blz. 84. 
feit dat de rechtsgevolgen van het ontslag verder gaan dan die van schorsing zou moeten volgen dat ontslag eerder rechtvaardiging behoeft dan schorsing. Maar ook afgezien daarvan kan het genoemde verschil in rechtsgevolg niet leiden tot een verschillend rechtsregime, nu de twee handelingen dezelfde aard hebben en onderworpen zijn aan dezelfde wettelijke regeling.

Zoals Van Oven ${ }^{46}$ terecht stelt, is het enige waarop het aankomt bij een door de rvc verleende schorsing "of de r.v.c. meende in het belang der n.v. tot schorsing te moeten overgaan." Wanneer de ava het schorsend orgaan is, zal moeten worden aangenomen dat de bevoegdheid om "te allen tijde" te schorsen slechts wordt beperkt door het verbod van art. 3:13 BW. ${ }^{47}$

\section{Ontslag van bestuurders}

Over het ontslag van de bestuurder kan in beginsel hetzelfde worden gezegd als over de benoeming, met dien verstande dat het ontslag het omgekeerde effect heeft, namelijk het einde van het bestuurderschap. Anders dan de benoeming, behoeft het ontslag niet te worden aanvaard. Terwijl de aanvaarding van een ambt niet aan de kandidaat kan worden opgelegd, is eenzijdige beëindiging van de verhouding in ons recht wel mogelijk. Het bestuurderschap kan dan ook "te allen tijde" door het tot ontslag bevoegde orgaan worden beëindigd (artt. 134 en 147). De bestuurder kan eveneens zijn bestuurderschap eenzijdig beëindigen. Beëindiging kan gepaard gaan met de verplichting tot betaling van schadevergoeding voor zover de vennootschap c.q. de bestuurder door het ontslag onrechtmatig is benadeeld.

Het ontslagbesluit is een tot de bestuurder gerichte eenzijdige handeling van de vennootschap. Met betrekking tot eenzijdige rechtshandelingen bepaalt art. 3:37 lid 3 BW: "Een tot een bepaalde persoon gerichte verkla-

46. WPNR 5571 (1981), blz. 452.

47. Het Handboek verwijst, ter ondersteuning van de in de tekst bestreden stelling, naar HR 28 juni 1963, NJ 1963, 483, Pres. Rb Amsterdam 28 december 1979, NJ 1980, 458 en Pres. Rb 's Hertogenbosch 7 november 1983, KG 1983, 353. Het arrest van de Hoge Raad behandelt niet de materiële gronden van de schorsing, zodat daaraan terzake geen argument kan worden ontleend. De twee vonnissen in kort geding gaan in werkelijkheid niet over de vennootschapsrechtelijke schorsing maar over schorsing in arbeidsrechtelijke zin. De eigen aard van de vennootschapsrechtelijke relatie wordt daarmee, in strijd met art. 134, miskend. Zo ook met betrekking tot het eerste vonnis Van Oven (WPNR 5571 (1981), blz. 451). Tenslotte wordt ook verwezen naar het in de tekst bestreden vonnis van Pres. Rb. Haarlem 17 december 1991, KG 1992, 38. 
ring moet, om haar werking te hebben, die persoon hebben bereikt." Het ontslagbesluit zal derhalve, om effectief te zijn, aan de ontslagen bestuurder dienen te worden medegedeeld. ${ }^{48}$ Dit betekent echter niet dat het besluit elk effect mist zolang het niet is medegedeeld. Naar mijn mening kan het ontslagbesluit bijvoorbeeld ter inschrijving in de Kamer van Koophandel worden aangeboden zonder dat voorafgaande kennisgeving aan betrokkene noodzakelijk is. Om het besluit effect te laten sorteren is het voldoende dat het ontslagvoornemen van de rechtspersoon op enigerlei wijze naar buiten toe blijkt.

Zoals reeds hiervoor gezegd, kan het bestuurderschap samengaan met een contractuele verhouding tussen vennootschap en bestuurder. Op dit punt geldt mijns inziens het beginsel dat, op dezelfde manier als benoeming tot bestuurder niet ea ipsa de aanstelling als werknemer medebrengt, de beëindiging van het bestuurderschap niet het slaken van de contractuele band met zich brengt. Omgekeerd geldt hetzelfde. Het begin of het einde van het werknemerschap betekent niet een gelijk gevolg voor het bestuurderschap. Omdat het bestuurderschap een andere rechtsverhouding is dan de arbeidsovereenkomst, kunnen beide rechtsverhoudingen in beginsel onafhankelijk van elkaar ontstaan en voortbestaan.

De zelfstandigheid van de vennootschapsrechtelijke en de arbeidsrechtelijke verhouding kan zich in het bijzonder doen gevoelen bij de beëindiging van eerstgenoemde verhouding, omdat deze te allen tijde kan geschieden, terwijl voor de opzegging van de arbeidsrechtelijke relatie dwingende voorschriften gelden. Tot het arrest van de Hoge Raad in de zaak Levi$\operatorname{son}^{49}$ werd algemeen aangenomen dat ontslag uit het bestuurdersambt de gelijktijdige beëindiging van de arbeidsrelatie betekende. ${ }^{50}$ Het arrest gaat uit van het naast elkaar bestaan van beide relaties, welke relaties ieder voor zich in beginsel een eigen leven leiden. ${ }^{3}$ Het is, in de recente literatuur, de verdienste van Huizink geweest op de zelfstandigheid van beide relaties te wijzen. ${ }^{32}$

Het voorgaande impliceert niet dat tussen de arbeidsrechtelijke en de vennootschapsrechtelijke relatie geen onderlinge beïnvloeding bestaat. Ontslag uit het besturdersambt kan er toe leiden dat de gewezen bestuur-

48. Evenzo HR 8 december 1989, NJ 1990, 452. Zie ook de noot van Maeijer onder het arrest.

49. HR 13 november 1992, NJ 1992, 265.

50. Zie, met verschillende nuances, Handboek, nr. 254; Van Schilfgaarde (1992), nr. 46; Roelvink, NJB 1981, blz. 76; Timmerman, De NV 63 (1985), blz. 7; Duk, WPNR 5958 (1990), blz. 273-274; Oderkerk, De NV 69 (1991), blz. 290.

51. Anders echter Van Schilfgaarde, WPNR 6093 (1993), blz. 389, r.k.

52. Diss. (1989), passim. 
der in zijn hoedanigheid van werknemer niet langer in stat is de bedongen arbeid te verrichten. Dit kan de overeenkomst ontbindbaar maken wegens het intreden van een gewichtige reden (art. 7A:1639w). Deze wederzijdse beïnvloeding vindt haar grondslag in het feit dat de feitelijke werkzaamheden, die het onderwerp zijn van de beide relaties, gelijk zijn. Zoals Van der Grinten stelt: "De arbeidsprestatie en de taak waartoe de bestuurder krachtens de arbeidsovereenkomst gehouden is, zijn niet anders dan de taak en functie van de bestuurder. ${ }^{53}$ Deze samenval van de feitelijke werkzaamheden leidt kennelijk tot de gedachte dat er slechts sprake is van eén rechtsverhouding. Zoals reeds boven is opgemerkt, is deze gedachte mijns inziens onjuist, omdat de realiteit van de rechtsverhoudingen (en dus hun aantal) niet bepaald wordt door de feitelijkheden die zij regelen, maar door de rechtsnormen die het feitencomplex beheersen. ${ }^{54}$

De problemen waartoe het ontslag van de bestuurder aanleiding kan geven behoren niet tot het domein van het rechtspersonenrecht. De problemen rijzen binnen de arbeidsrechtelijke verhouding en dienen dan ook vanuit het arbeidsrecht te worden opgelost. ${ }^{55}$

Voor het ontslag geldt, evenals voor de schorsing, dat de bevoegdheid om ontslag "te allen tijde" te verlenen niet medebrengt dat deze bevoegdheid arbitrair kan worden uitgeoefend. De rvc is, zoals steeds, ook bij de uitoefening van de ontslagbevoegdheid an het belang van de vennootschap gebonden. De woorden "te allen tijde" houden wel een ruime beoordelingsmarge bij de verlening van het ontslag in. ${ }^{36}$

Ik zou menen dat de bestuurder, waar het betreft de ontslagverlening,

53. De NV 71 (1993), blz. 48.

54. Van der Grinten (t.a.p., blz. 49) stelt, terecht, dat zijn visie de voorkeur verdient in zoverre "de anomalie van het stelsel van de Hoge Raad dat wel het bestuurderschap eindigt doch de arbeidsovereenkomst formeel voortduurt, wordt vermeden." Deze visie doet echter onvoldoende recht aan het zelfstandig karakter dat beide rechtsverhoudingen in onze rechtsorde hebben. Dat het van belang is ledere rechtsverhouding volgens haar eigen normen te regelen, blijkt vooral wanneer beide normencomplexen uiteen lopen, zoals bijvoorbeeld op het punt van aansprakelijkheid (hierna $\$ 17, \mathrm{I}$ ).

55. Zie over de vraag of het voortbestaan van het werknemerschap contractueel kan worden gekoppeld aan het voortduren van het besturderschap Huizink (1989), blz. 68 e.v. en S.M. Bartman, Ziek zijn en ontslagen worden. Over de psychische belasting van een bestuurder, NJB 1993, blz. 825 .

56. Het vennootschapsrechtelijke ontslag van de bestuurder behoeft geen 'zakelijke rechtvaardiging'. Ook uit het arrest van de Hoge Raad d.d. 4 december 1992, NJ 1993, 271 (Meijers/Mast) volgt naar mijn mening niet het tegendeel. Het ging i.c. mede om het arbeidsrechtelijke ontslag (art. 7A:1639s). 
geen 'hoorrecht' heeft. ${ }^{57}$ De bestuurder heeft niet een recht om te worden gehoord omdat hij, gezien de macht van het bevoegde orgaan om ontslag "te allen tijde" te verlenen, geen aanspraak kan maken op continuïteit in zijn ambt. ${ }^{58}$ Daarom kan ook uit de redelijkheid en billijkheid van art. 8 voor de vennootschap geen 'verplichting' voortvloeien om de bestuurder bij de totstandkoming van het besluit te betrekken, noch zal sprake zijn van rechtsmisbruik als de bestuurder niet is gehoord. ${ }^{59}$ Alleen onder uitzonderlijke omstandigheden zal er sprake zijn van uitoefening van bevoegdheid in strijd met art. 8. Men denke bijvoorbeeld aan het geval dat de rvc als schorsend orgaan aan betrokkene of an de ava heeft toegezegd de te schorsen persoon van tevoren te zullen horen.

\section{§ 8. Bevoegdheden met betrekking tot de jaarrekening}

"De regeling omtrent de taak en bevoegdheden van de vennootschapsorganen ten aanzien van de jaarrekening behoort niet tot de meest geslaagde onderdelen van de vennootschapswetgeving. ${ }^{160}$ Zoveel is duidelijk: de wet bevat voor structuur- en gewone vennootschappen rechtsregimes die niet identiek zijn. Aan deze kwestie wordt hierna aandacht besteed. Voorts worden de bevoegdheden van de rvc terzake van de benoeming van de accountant besproken.

\section{Vaststelling van de jaarrekening}

De jaarrekening beoogt een zodanig inzicht te geven "dat een verantwoord oordeel kan worden gevormd omtrent het vermogen en het resultaat, alsmede voor zover de aard van de jaarrekening dat toelaat, omtrent de

57. Kennelijk anders Van den Ingh, WPNR 6095 (1993), blz, 457 e.v. en enkele van de door schrijver aangehaalde rechterlijke uitspraken.

58. In deze zin Staudinger-Coing, $\S 27 \mathrm{Rz} 14$. Wanneer de OK (18 mei 1989, NJ 1990, 591 (WTC)) concludeert dat de ratio van art. 117 lid 4 medebrengt dat de bestuurder gehoord dient te worden over zijn ontslag, zelfs wanneer de ava buiten vergadering besluit, stelt de OK een eis die door de wet niet wordt gesteld. De raadgevende stem die art. 117 lid 4 aan bestuurders en commissarissen toekent is, zoals uit de door de OK gememoreerde wetsgeschiedenis blijkt, een bevoegdheid die de bestuurder wordt verleend in het belang van de ava teneinde aandeelhouders te oriënteren bij de besluitvorming. Een 'hoorrecht' van de bestuurder bij de besluitvorming omtrent zijn eigen ontslag kan echter uit art. 117 niet worden afgeleid. De ava is niet gehouden het advies van de bestuurder te horen.

59. Zo echter Van den Ingh (1993), 457.

60. Van der Grinten (1979), blz. 18. 
solvabiliteit en liquiditeit van de rechtspersoon" (art. 362). De jaarrekening is het stuk dat door de bevoegde organen, conform de wettelijke eisen, als zodanig is vastgesteld. Wat betreft de bevoegdheden met betrekking tot de totstandkoming van de jaarrekening onderscheidt de wet tussen de bevoegdheid tot opmaken, vaststellen en goedkeuren. Aan het bestuur komt de bevoegdheid toe om de jaarrekening op te maken (art. 101 lid 1). Deze bevoegdheid omvat de bepaling van de inhoud van de jaarrekening. In navolging van IJsselmuiden ${ }^{61}$ zou $\mathrm{ik}$ op dit punt willen onderscheiden tussen het registreren van feiten die van invloed zijn op de jaarrekening en het beoordelen van deze feiten. De eerste werkzaarnheid is van feitelijke aard en behoort tot de exclusieve competentie van het bestuur. De tweede werkzaamheid heeft te maken met de rechtsgevolgen die aan de kwalificatie van de feiten zijn verbonden. Op dit punt heeft het bestuur een eerste competentie bij het opmaken van de jaarrekening, maar de wet geeft ook aan andere organen zeggenschap daarover. In zoverre behoort de materie dan ook niet tot de exclusieve competentie van het bestuur. De zeggenschap van de vennootschapsorganen op dit punt is verschillend bij gewone en structuurvennootschappen.

In het gewone model bevat de wet geen expliciete regeling van de bevoegdheden van de rvc inzake de jaarrekening. Art. 101 bepaalt slechts dat de commissarissen de door het bestuur opgemaakte jaarrekening ondertekenen. De ava dient vervolgens de jaarrekening "vast te stellen" (art. 101 lid 3). In het structuurregime dient de door het bestuur opgemaakte jaarrekening door de rvc te worden vastgesteld, waarna goedkeuring door de algemene vergadering dient plaats te vinden (art. 163). De vaststellingsbevoegdheid houdt de macht in om de jaarrekening te wijzigen. ${ }^{62}$ Zowel de algemene vergadering bij gewone vennootschappen als de rvc bij structuurvennootschappen hebben derhalve de bevoegdheid om over het door het bestuur opgemaakte stuk naar eigen inzicht (de rve in het belang van de vennootschap) te beschikken. Doch de positie van de rvc is in geen van beide regimes geheel duidelijk. Immers, welke is zijn concrete bevoegdheid in het gewone model, en hoe verhoudt zich in het structuurregime de

61. Rechtspersonen, Inleiding bij Titel 9, 2.3.2.

62. Zie met betrekking tot het structuurregime Maeijer, Wetsgeschiedenis, IXf - Art. $52 \mathrm{~m}$ (III) 3: "Uit het voorschrift dat de jaarrekening wordt vastgesteld door de raad van commissarissen en dat zij de goedkeuring van de aandeelhoudersvergadering behoeft, volgt het ontbreken van een recht van amendement voor dit laatste orgaan", en blz. 4: "Uit de bepaling dat de raad van commissarissen de jaarrekening vaststelt, volgt dat hij tevens wijzigingen kan aanbrengen: hij neemt dan een nieuw vaststellingsbesluit. Het enkele goedkeuringsrecht houdt geen bevoegdheid tot het aanbrengen van wijzigingen in." Vgl. ook IJsselmuiden, Rechtspersonen, Inleiding Titel 9,2.3. 
'ondertekeningsplicht' van art. 101 lid 2 tot de vaststellingsplicht van art. 163 ?

Te beginnen met de eerste vraag, is de bevoegdheid van de rvc, zoals zojuist is opgemerkt, beperkt tot de ondertekening van de jaarrekening (art. 101 lid 2). De wet zegt niet met zoveel woorden wat deze bevoegdheid precies inhoudt. Ondertekening van de jaarrekening wil in ieder geval zeggen dat de ondertekenende commissarissen zich met de inhoud van het stuk verenigen. Instemming van commissarissen met de door het bestuur opgemaakte jaarrekening heeft rechtens een eigen betekenis. Commissarissen dragen door de ondertekening een zekere verantwoordelijkheid voor de correctheid van de jaarrekening (art. 150). Uit het systeem van de wet en uit haar geschiedenis leidt Van der Grinten ${ }^{63}$ af dat de jaarrekening een gezamenlijk stuk is van bestuur en rvc, voor zover "het opmaken van de jaarrekening (...) niet een autonome bevoegdheid van het bestuur is, doch een opdracht die het bestuur onder toezicht van commissarissen dient te vervullen. (...) Het toezicht houdt [in] dat het bestuur slechts met instemming van commissarissen -of beter en scherper met instemming van de raad van commissarissen- de jaarrekening kan opmaken." Deze instemming met de door het bestuur opgemaakte jaarrekening blijkt dan uit het met die bedoeling genomen besluit van de rvc. De visie van Van der Grinten lijkt mij in zoverre juist dat daarin duidelijk tot uitdrukking komt dat de jaarrekening niet een aan de rvc vreemd stuk is, doch dat zij in zekere zin het gevolg is van de toezichthoudende taak van dit orgaan. Anderzijds lijkt mij dat deze visie afbreuk doet aan de zelfstandige taakuitoefening van het bestuur. Het standpunt van Van der Grinten komt er mijns inziens op neer dat het bestuur zich slechts met medewerking van de rvc van zijn taak kan kwijten. Het opmaken van de jaarrekening is dan een gezamenlijke aangelegenheid van bestuur en rvc. Ook aan de rvc komt de opmakingsbevoegdheid toe, zij het dat de raad deze bevoegdheid deelt met het bestuur. Ik zou echter menen dat de door het bestuur opgemaakte jaarrekening niet de goedkeuring van de rvc behoeft te dragen om als bestuursstuk te kunnen gelden. In beginsel zal het bestuur zijn taak met betrekking tot de jaarrekening hebben vervuld wanneer het bestuur het opmakingsbesluit genomen heeft. Het ontbreken van de handtekening van de commissarissen zal gevolgen hebben voor het stuk dat het bestuur heeft geconcipieerd. Het stuk zal niet kunnen zijn de opgemaakte jaarrekening in de zin der wet. Echter, de bevoegdheden van rvc en bestuur met betrekking tot de jaarrekening zijn, als uitvloeisel van de respectievelijke taken, verschillend. Het opmaken, in bovengenoemde zin van verzamelen van gegevens en waarderen ervan, geschiedt door het bestuur onder eigen verantwoordelijkheid. Uit

63. (1979), blz. 19. 
de controlerende taak van de rvc volgt dat de bevoegdheid van commissarissen zich beperkt tot een fiattering van de werkzaamheden van het bestuur, maar niet dat bestuur en rvc gezamenlijk de jaarrekening opmaken. Daar deze fiattering iets anders is dan de opmakingsbevoegdheid van het bestuur en zij de macht inhoudt het stuk van het bestuur te wijzigen, is zij mijns inziens te beschouwen als vaststellingsbevoegdheid. Op dit punt is de bevoegdheid van de rvc naar mijn mening dezelfde in het gewone en in het structuurmodel. ${ }^{64}$ Dit blijkt mijns inziens bij de beantwoording van de hiervoor gestelde tweede vraag, namelijk de verhouding tussen de 'ondertekeningsplicht' van art. 101 lid 2 tot de vaststellingsplicht van art. 163.

Naar het oordeel van Van der Grinten vallen opmaking en vaststelling in de praktijk van het structuurregime steeds samen. ${ }^{65}$ Zij zijn niet te onderscheiden rechtshandelingen. ${ }^{66}$ Ik deel deze opvatting, maar zie niet in waarom op dit punt de situatie in het gewone en in het structuurregime zou verschillen. Als de bevoegdheid ex art. 163 gelijk is aan die ex art. 101, dient de conclusie te zijn dat, ook wanneer art. 163 niet geldt, de rvc op grond van art. 101 een vaststellingsbevoegdheid bezit. Op dit punt lijkt mij derhalve geen verschil te bestaan tussen beide vennootschapsmodellen. Van der Grinten stelt dat in zijn visie "niettemin verdedigbaar [is], dat de bevoegdheden van de raad van commissarissen ten aanzien van de jaarrekening van struktuurvennootschappen verder kunnen gaan dan bij gewone vennootschappen. ${ }^{167}$ Schrijver doet vervolgens een beroep op het departementale standpunt volgens hetwelk de vaststellingsbevoegdheid van de ava (art. 101 lid 3) niet kan worden aangetast door enig vennootschapsorgaan, terwijl de statuten van structuurvennootschappen terzake wel zekere bevoegdheden konden toekennen aan de rvc ( $\$ 45$ en 59 Dep. Richtl. 1976; huidige § 12). Daarmee wordt mijns inziens echter niets gezegd over de vraag waar het hier om gaat, namelijk de bevoegdheid van de rvc bij gewone vennootschappen. Er wordt slechts -indirect- gezegd dat krachtens de wet de algemene vergadering in het structurregime terzake van de jaarrekening minder zeggenschap heeft dan in het gewone model. Maar dit laat op zich de mogelijkheid onverlet dat ook in het gewone model aan de rvc een vaststellingsbevoegdheid toekomt.

Het lijkt mij inderdaad dat het verschil in bevoegdheid terzake van de jaarrekening niet zozeer bij de rvc dient te worden gezocht als wel bij de

64. Zo ook Van der Grinten (1981), blz. 57.

65. Handboek, nr. 318.

66. (1979), blz. 20.

67. (1979), blz. 20. 
algemene vergadering. ${ }^{68}$ De enige wijziging in de verdeling van bevoegdheden die art. 163 naar mijn mening met zich brengt, is dat de definitieve vaststellingsbevoegdheid in het structuurregime bij de rvc ligt. De ava kan slechts de door de rvc vastgestelde jaarrekening goed- of afkeuren, maar zij heeft geen zeggenschap over de afzonderlijke posten. Daarentegen bestaat in het gewone regime een dubbele vaststellingsbevoegdheid. In de eerste plaats die van de rvc op grond van art. 101 lid 2 en in de tweede plaats die van de algemene vergadering op grond van het derde lid van hetzelfde artikel. Terwijl derhalve in het structuurregime de rvc de definitieve zeggenschap heeft over de posten van de jaarrekening, is de bevoegdheid van de raad in het gewone model onderworpen aan het oordeel van de algemene vergadering. ${ }^{69}$

Het lijkt mij dat tegen de hier verdedigde interpretatie van het obscure artikel 101 slechts een taalkundig argument kan worden ingebracht, en dat is dat de bevoegdheid van de rvc niet met zoveel woorden als vaststellingsbevoegdheid wordt geduid. Dit argument acht ik echter niet doorslaggevend. $\mathrm{Nu}$, naar mijn mening, de bevoegdheid van de rvc ex art. 101 lid 2 hetzelfde inhoudt als de vaststellingsbevoegdheid van art. 163, dient zij als een zodanige bevoegdheid te worden beschouwd.

Voor deze opvatting pleit voorts dat daarmee een meer uniforme regeling tussen structuur- en gewone vennootschappen wordt bewerkstelligd waar het betreft de positie van de rvc. Zoals gezegd, vloeit uit de wet voort dat het verschil in toebedeling van bevoegdheden slechts de algemene vergadering betreft, an welk orgaan in het structuurregime de vaststellingsbevoegdheid wordt ontnomen. De bevoegdheden van bestuur en rvc zijn echter in beide systemen gelijk. Dit laat zich illustreren aan de hand van een concreet voorbeeld.

In het wettelijk systeem is de jaarrekening een gezamenlijk stuk van bestuur en commissarissen. Voor de totstandkoming van de jaarrekening is een besluit van beide organen vereist. De vraag doet zich voor wat rechtens is wanneer de rvc weigert zijn instemming te geven aan de door het bestuur opgemaakte jaarrekening. Van der Grinten ${ }^{70}$ beantwoordt deze vraag verschillend al naar gelang de kwestie zich voordoet bij een gewone dan wel bij een structuurvennootschap. Terwijl volgens hem in het gewone model het bestuur bevoegd is de jaarrekening op te maken en ter vaststelling aan de ava over te leggen zonder de handtekening van commissarissen,

68. Vgl, Van der Grinten (1981), blz. 42: "De duidelijke bedoeling van de wettelijke regeling van struktuurvennootschappen is de bevoegdheid van de algemene vergadering te beperken."

69. Zulks geldt ook voor die variaties van het structuurregime waarin de ava bevoegd is tot vaststelling.

70. Handboek, nr. 318 . 
dient in het structuurmodel het oordeel van de commissarissen te prevaleren. Naar mijn mening biedt de wet onvoldoende steun voor deze opvatting. Het is niet in te zien waarom, uitgaande van de gelijkheid van taak en bevoegdheid van bestuur en rvc bij beide soorten vennootschappen, er een verschillend regime zou moeten gelden. Ik zou menen dat in beide gevallen het oordeel van de rvc dient te prevaleren omdat de wet aan dit orgaan steeds de macht toekent de door het bestuur opgemaakte jaarrekening te wijzigen. Het enige verschil is dat, terwijl bij de gewone vennootschap het oordeel van de rvc vervangen kan worden door het eigen oordeel van de algemene vergadering, bij de structuurvennootschap het oordeel van de rvc in zoverre definitief is dat de ava dit slechts kan aanvaarden of verwerpen.

\section{Benoeming van de accountant}

De benoeming van de accountant is een bevoegdheid van de ava (art. 393 lid 2). Het voorstel tot (her)benoeming zal, met name bij grote vennootschappen, een initiatief zijn van de leidinggevende organen.

De benoemingsbevoegdheid komt aan de rvc toe voor zover de ava in gebreke blijft de benoeming te verrichten. Benoeming door de rvc is nietig indien de ava nog tot benoeming kan overgaan. Immers, het besluit is in dat geval in strijd met de wet genomen. Hoewel de wet niet expliciet aangeeft wanneer het moment aanbreekt waarop de rvc bevoegd moet worden geacht, kan worden aangenomen dat dit moment intreedt na de jaarlijkse algemene vergadering, indien de ava niemand heeft aangewezen. ${ }^{71}$ Zulks wil niet zeggen dat bij benoeming door de rvc de ava geheel verstoken is van haar benoemingsbevoegdheid. Daar de ava de door de rvc verstrekte opdracht "te allen tijde" kan intrekken (art. 393 lid 2), is zij steeds bevoegd de accountant te benoemen die haar welgevallig is. De enkele omstandigheid dat de intrekking van de reeds door de rvc verleende opdracht wanprestatie van de vennootschap jegens de accountant kan opleveren, staat aan de geldigheid van het intrekkingsbesluit niet in de weg. Hetzelfde geldt mutatis mutandis bij intrekking van de opdracht door de rve.

De taak van de accountant is niet volbracht met het afleggen van de verklaring bedoeld in het vijfde lid van art. 393. Hij dient aan de rvc en aan het bestuur verslag uit te brengen van zijn bevindingen (art. 393 lid 4). ${ }^{72}$ In

71. In gelijke zin Burgert-Timmermans-Joosten (1990), art. 393, 2.4.1.

72. Zie over de verhouding tussen rve en accountant R.A. Bak, Commissaris en Accountant, TVVS 1982, blz. 29 e.v. 
tegenstelling tot de verklaring, is het verslag van de accountant een interne aangelegenheid van de vennootschap. Daarin geeft de accountant zijn visie op de gecontroleerde jaarrekening. De omvang van de informatieplicht van de accountant kan niet in abstracto worden bepaald. Als algemeen criterium kan gelden dat de accountant verplicht is om rvc en bestuur alle conclusies van een gedegen onderzoek mede te delen.

Onder normale omstandigheden heeft de accountant niet de rol van informant van de rvc. Uitdrukkelijk bepaalt art. 141 dat het bestuur aan de rvc de voor de uitoefening van de commissariële taak noodzakelijke gegevens verstrekt. De 'informant' van de rvc is in het systeem van de wet het bestuur. ${ }^{3}$ Dit lijdt slechts uitzondering wanneer de rvc van oordeel is dat de informatieverschaffing door het bestuur onvoldoende is, of de commissarissen het anderszins in het belang van de vennootschap geraden achten dat zij door anderen dan het bestuur geïnformeerd worden. ${ }^{74}$

\section{\$9. Goedkeuring van bestuursbesluiten}

De toezichthoudende taak van de rvc vereist om effectief te zijn een zekere zeggenschap met betrekking tot de bestuursmacht van het bestuur. De commissariële controle is niet goed denkbaar indien het bestuursorgaan zijn beleid zonder enige binding aan het toezichthoudend college zou mogen voeren. Daarom heeft de wetgever, waar hij de positie van de rvc heeft willen versterken, bepaalde besluiten van het bestuur onderworpen aan de goedkeuring van de rvc. Aan de rvc bij structuurvennootschappen komt dit goedkeuringsrecht toe krachtens art. 164. Bij vennootschappen waarvoor art. 164 niet van toepassing is kan aan de rvc een zelfde zeggenschap statutair worden toegekend. Of het goedkeuringsrecht van de rvc een wettelijke dan wel een statutaire basis heeft is voor de controlerende taak van commissarissen, en dientengevolge voor de leidinggevende taak van bestuurders, niet van belang. In beide gevallen wordt de taakvervulling van de rvc bepaald door dezelfde bevoegdheden. ${ }^{75}$

73. In deze zin ook Bak, t.a.p., blz. 31.

74. Evenzo Rb. Breda 1 mei 1990, NJ 1990, 740, blz. 3077, 1.k. (Tilburgsche Hypotheekbank).

75. Hiermee is niet gezegd dat de verschillende grondslag elke betekenis mist. Aan de rve van een gewone vennootschap zou bijwoorbeeld de goedkeuringshevoegdheid middels statutenwijziging kunnen worden ontnomen. Bij een structuurvennootschap is dit niet mogelijk. 


\section{Onderwerp van de goedkeuring}

De goedkeuringsbevoegdheid van de rvc op grond van art. 164 laat de verdeling van bevoegdheden onder de vennootschapsorganen onverlet. ${ }^{76}$ Het resultaat dat de wet beoogt te bereiken, namelijk toekenning van zeggenschap aan de rvc in belangrijke aangelegenheden van de vennootschap, zou echter kunnen worden gefrustreerd indien niet het bestuur maar een ander vennootschapsorgaan het besluit zou nemen waarvoor goedkeuring van de rvc nodig is. Zo bijvoorbeeld indien emissie van aandelen krachtens besluit van de algemene vergadering geschiedt, in plaats van krachtens besluit van het bestuur. Men zou kunnen stellen dat niet het bevoegde orgaan het criterium zou dienen te zijn voor de uitoefening van de goedkeuringsbevoegdheid, maar het feit dat de transactie in kwestie het vennootschappelijk belang in belangrijke mate raakt. ${ }^{77}$

Uitbreiding van de goedkeuringsbevoegdheid van de rvc wordt verdedigd met een beroep op de ratio van de Structuurwet. ${ }^{78}$ Een verzwaring van de positie van het toezichthoudend college zou beter passen in het wettelijk systeem. Voor deze opvatting wordt steun gezocht in de voorstellen van de commissie Verdam ${ }^{79}$ en in het SER-advies inzake de herzie-

76. Zie, voor allen, Maeijer (1973), blz. 24 .

77. Hiervoor is verdedigd dat de toezichthoudende taak van de rvc zakelijk en niet organiek bepaald is $(\$ 1, \mathrm{II})$. Dat wil zeggen dat het toezicht niet slechts het bestuurshandelen betreft, maar ook elk handelen van andere vennootschapsorganen dat voor de vennootschap van een zeker belang is. Hieruit volgt niet dat dus de controlerende taak van commissarissen terzake van genoemde besluiten toekenning van een goedkeuringsrecht impliceert.

78. Zie De Graaf, TVVS 1974, biz. 230-231 en Timmerman, Rechtspersonen, art. 164, aant. 2.

79. Vgl. art. $50 \mathrm{j}$ van het voorontwerp van de Commissie: "De akte van oprichting vermeldt, welke besluiten slechts op voorstel of met toestemming van commissarissen kunnen worden genomen." Veelzeggend is, naar mijn mening, de volgende passage uit de toelichting op art. 50j van het ontwerp van de Commissie Verdam: "De wet (...) draagt de bevoegdheid tot het nemen van deze besluiten [tot stafutenwijziging en ontbinding JMBF] op aan de algemene vergadering van aandeelhouders, en daarin wordt geen verandering voorgesteld; slechts [!] wordt bepaald dat deze besluiten behoren te worden genomen op voorstel, of althans met instemming, van commissarissen. Overwogen is, of het niet de voorkeur verdient ook het nemen van deze besluiten toe te vertrouwen aan de raad van commissarissen; hiervan is evenwel afgezien, om voorshands niet een te sterke breuk met de tegenwoordige toestand te veroorzaken" (mijn curs.). Zowel de eis van instemming van de rvc met voornoemde besluiten, als toekenning aan de rvc van de bevoegdheid om die besluiten te nemen, komen de facto op hetzelfde neer. De ava kan niet autonoom beslissen omtrent statutenwijziging en ontbinding. 
ning van het Ondernemingsrecht. ${ }^{80}$ Ook de vervanging van het woordje "tot" door "omtrent" bij de Invoeringswet Boek 2 nieuw BW zou voor uitbreiding van de commissariële bevoegdheid pleiten.

Deze argumenten lijken mij niet concludent. Uitbreiding van de commissariële bevoegdheden bergt het risico in zich dat het doel van de Structuurwet voorbij wordt gestreefd. Het gaat er niet om, aan de rvc over alle belangrijke onderwerpen het laatste woord te geven. Een dergelijk college zou dan meer weg hebben van een super-bestuur dan van een controlerend orgaan. Bij de controlerende taak van de rvc past ook niet de toekenning aan dit orgaan van een vetorecht ten aanzien van belangrijke besluiten van de algemene vergadering, zoals uitgifte van aandelen, statutenwijziging of ontbinding. De kapitaalvennootschap wordt met een dergelijk vetorecht gedenatureerd. Ook in het systeem van de Structuurwet blijft de naamloze vennootschap "de organisatie der risicodragende kapitaalverschaffers. " ${ }^{81}$

Gesteld zou kunnen worden dat het voorgaande betrekkelijk is, in zoverre dat de zeggenschap van de algemene vergadering beperkt kan worden door middel van prioriteitsrechten. Het verschil is echter dat in het geval van de prioriteitsrechten de beperking van bevoegdheden op een autonome beslissing van de kapitaalverschaffers berust, en niet op een dwingend voorschrift. In overeenstemming met het autonomie-beginsel staat de mogelijkheid van beperking van bevoegdheden ter beschikking van de rechtsgenoten. Middels statutenwijziging kan de prioriteit worden ontmanteld. ${ }^{82}$

De wetgever heeft de concernrechtelijke dimensie van het onderwerp

80. Advies d.d. 19 september 1969, Uitgave van de SER nr. 14, blz. 24-25.

81. Aldus de MvT, Maeijer, Wetsgeschiedenis, IXf - 16. De correctheid van de gebruikte uitdrukking nu daar latend, komt mijns inziens daarin duidelijk naar voren dat kapitaalverschaffing het determinerend element van de vennootschap is. Anders $P$. Sanders, Nieuwe wijn in oude zakken, TVVS 1971, blz.90 en Van Schilfgaarde (8ste druk) nr. 144 ("typisch overblijfsel van de intussen wat verouderde gedachte dat nv en bv organisaties van kapitaalverschaffers zijn.") Aangehaalde passage is in de 9de druk geschrapt. Ook in art. 12 van het ontwerp 5e EGrichtlijn worden alleen besluiten van het bestuur aan goedkeuring van het toezichthoudend orgaan onderworpen.

82. Ook de bevoegdheid tot statutenwijziging zou beperkt kunnen worden. Betoogd wordt dat deze en soortgelijke statutaire voorzieningen zelfs "kunnen verhinderen dat de algemene vergadering haar wettelijke bevoegdheden kan uitoefenen" (Van der Grinten, Structuurregeling als beschermingsconstructie (1990), blz. 15.) Zulks lijkt mij echter in strijd met de wet. Op dezelfde manier als een natuurlijk persoon geen afstand kan doen van zijn zelfbeschikkingsrecht, kan de algemene vergadering zichzelf niet beletten de haar dwingend toekomende bevoegdheden uit te oefenen. 
onderkend, maar hij heeft zich daarbij mijns inziens enigszins bezondigd aan een excessieve systematiseringsdrang. Het artikel gebruikt de term 'afhankelijke maatschappij' om de afhankelijkheidssituatie te duiden. ${ }^{83}$ Deze opzet is verdedigbaar vanuit het standpunt dat art. 164 deel uitmaakt van Afdeling 6 (Titels 4 en 5) over de structuurvennootschappen (art. 152). Ik zou echter menen dat i.c. niet het rechtsregime van de vennootschap doorslaggevend zou dienen te zijn, maar de economische gevolgen van de betrokken transactie voor de groep. Het ruimere begrip 'groepsmaatschappij' zou naar mijn mening beter stroken met de bedoeling van art. 164 . Gezien echter de expliciete keuze van de wetgever op dit punt, lijkt mij lege lata geen ruimte te zijn voor deze interpretatie. Overigens zou in de statuten van de afhankelijke maatschappijen aan de rvc van de moedervennootschap een goedkeuringsrecht kunnen worden toegekend. In dat geval oefent de rvc zijn controlerende taak niet als orgaan van de moeder, en dus ook niet in het kader van art. 164, maar als orgaan van de afhankelijke maatschappij uit.

Over het onderwerp van goedkeuring bestaat in de literatuur verschil van inzicht. Niet geringe betekenis wordt daarbij toegekend aan de vervanging in de aanhef van lid 1 van art. 164 van het woord "tot" door "omtrent". ${ }^{44}$ Ik meen echter, mede gezien het feit dat de vervanging in de parlementaire stukken niet nader gemotiveerd wordt, dat de grammaticale interpretatie ons bij de uitleg van art. 164 niet verder helpt. Voorts zal het grammaticale argument van weinig nut zijn wanneer het goedkeuringsrecht statutair verleend is, en ook in dit geval kan noodzakelijk zijn vast te stellen of een bepaald bestuursbesluit aan commissariële goedkeuring dient te worden onderworpen.

Vaststelling van de inhoud van de goedkeuringsbevoegdheid dient te geschieden tegen de achtergrond van het commissariële toezicht op het bestuur. De letterlijke tekst van de wettelijke of statutaire lijsten is niet steeds doorslaggevend voor de vraag of het bestuursbesluit goedkeuring behoeft. Het oordeel van de rvc bij de interpretatie van de hem toekomende bevoegdheden is in deze van belang. Daar de uitoefening van de goedkeuringsbevoegdheid alleen onder bepaalde omstandigheden plaatsvindt, waarmee wet en statuten niet steeds voldoende rekening kunnen houden, dient aan de rvc een zekere autonomie bij de interpretatie te worden erkend. Ik geef enkele voorbeelden. Onder de letters $g, h$ en $l$ van art. 164

83. De term kwam in de Structuurwet niet voor. Deze is ingevoerd bij Wet van 25 maart 1987, Stb. 112.

84. Zie met name Maeijer (1973), blz. 24 en 84; De Graaf (1974), blz. 225 e.v. en Timmerman, Rechtspersonen, art. 164, aant. 2. 
wordt gesproken over "een voorstel" van het bestuur. Gesteld wordt dat geen goedkeuring noodzakelijk is, indien het bestuur de betreffende onderwerpen op de agenda van een algemene vergadering zet zonder daarover enig voorstel te doen. ${ }^{85}$ Dit lijkt mij in zijn algemeenheid niet juist. Het agenderen van een dergelijk onderwerp op initiatief van het bestuur kan onder omstandigheden worden begrepen als zou het bestuur de totstandkoming van het besluit willen bevorderen. Het is dit al of niet expliciet bevorderen van een bepaald besluit dat door de rvc dient te worden gedekt. Ook het verkrijgen en afstoten van belangrijke deelnemingen vereist de goedkeuring van de rvc (art. 164 lid 1 sub $e$ ). Verdedigbaar is dat het in pand geven van de aandelen van de afhankelijke maatschappijen, hoewel niet met name genoemd, eveneens goedkeuring behoeft, althans wanneer de transactie ingrijpende gevolgen heeft voor de groep.

De vraag rijst of de rvc goedkeuring van bestuursbesluiten kan eisen zonder dat het besluit in kwestie in de wettelijke c.q. statutaire lijst voorkomt. Men denke bijvoorbeeld aan het voeren van een procedure met betrekking tot een aangelegenheid die het imago van de vennootschap kan schaden. ${ }^{86}$

Ik zou menen dat een zekere wettelijke of statutaire grondslag noodzakelijk is. De rvc ontleent zijn bevoegdheden aan wet en statuten. De toekenning van bevoegdheden behoeft mijns inziens echter niet expliciet te zijn. Op dezelfde manier als een contractuele verhouding aangevuld kan worden (art. 6:248 BW), kan uit het wettelijk systeem of uit het ongeschreven recht voortvloeien dat een bepaalde bevoegdheid impliciet aanwezig is in de taakstelling van de rvc. Gesteld zou kunnen worden dat terzake van de goedkeuringsbevoegdheid het positieve recht deze mogelijkheid uitsluit. Immers, in tegenstelling tot bijvoorbeeld art. 146, waar de rve zelfstandig kan oordelen of er zich een situatie van tegenstrijdig belang voordoet, worden de besluiten waarvoor goedkeuring vereist is in de wet met name genoemd. Anderzijds is het niet ongeoorloofd de wettelijke lijst statutair uit te breiden, waardoor aangenomen moet worden dat de rechtsgenoten op dit punt vrij zijn om de toezichthoudende taak van de rvc naar eigen inzicht te

85. Handboek, 275.1.

86. Vgl. in dit opzicht $\$ 111$, Abs. 4 AktG: "Maßnahmen der Geschäftsführung können dem Aufsichtsrat nicht übertragen werden. Die Satzung oder der Aufsichtsrat kann jedoch bestimmen, daß bestimmte Arten von Geschäften nur mit seiner Zustimmung vorgenommen werden dürfen." In het ontwerp vijfde EGrichtlijn (art. 12 lid 2) wordt daarentegen bepaald: "Andere handelingen kunnen bij de wet of de statuten aan de goedkeuring van het toezichthoudende orgaan worden onderworpen." Terwijl derhalve volgens de Duitse wet de Aufsichtsrat zonder wettelijke of statutaire basis kan interveniëren, lijkt een dergelijke basis in de ogen van de Eurowetgever wel een vereiste te zijn. 
verzwaren. En evenzeer als zij bevoegd zijn om bepaalde besluiten met name te vermelden, zijn zij mijns inziens bevoegd om statutair een algemene machtiging aan de rvc toe te kennen. Als grens zal daarbij gelden dat de goedkeuringseis niet dusdanig ver gaat dat het bestuur niet in staat is zijn taak zelfstandig uit te oefenen. ${ }^{87}$

\section{Het goedkeuringsbesluit}

Ratio van het onderwerpen van bepaalde bestuursbesluiten aan de goedkeuring van de rvc is dat commissarissen zeggenschap hebben in het vennootschappelijk beleid zoals dit door het bestuur bepaald wordt. Bezien vanuit de kant van het bestuur betekent de eis van commissariële goedkeuring dat het bestuur niet autonoom de vennootschap mag binden terzake van de transactie in kwestie. Anderzijds bepaalt de wet dat de vertegenwoordigingsbevoegdheid van het bestuur niet wordt aangetast door het ontbreken van goedkeuring (art. 164 lid 2), zodat het bestuur ook zonder de goedkeuring van de rvc de vennootschap terzake van de gewraakte transactie kan binden. De vertegenwoordigingsbevoegdheid van het bestuur reikt hier dan ook verder dan de toezichthoudende macht van de rvc. Deze voorrang vindt haar verklaring in de bescherming van het rechtsverkeer. In de visie van de wetgever kan het extern handelen van het bestuur terzake van een transactie in de zin van art. 164 als een handelen van de vennootschap gelden ondanks het feit dat, zonder de goedkeuring van de rvc, de bestuursmacht van het bestuur beperkt was. Bestuursmacht en vertegenwoordigingsbevoegdheid van het bestuur zijn op dit punt losgekoppeld.

De werking van het goedkeuringsbesluit van de rvc kan worden verduidelijkt door de regeling van art. 164 te vergelijken met de regeling van bestuursmacht en vertegenwoordigingsbevoegdheid van het bestuur bij vereniging en stichting. Ondanks zijn algemene vertegenwoordigingsbevoegdheid (artt. 45 lid 3 en 292 lid 3), kan het bestuur van vereniging en stichting de rechtspersoon in beginsel niet binden bij bepaalde in de wet genoemde transacties, die op zich tot de bestuurscompetentie kunnen behoren (artt. 44 lid 2 en 291 lid 2). Interne bestuursmacht is hier een

87. Wellicht wordt in de rechtspraak een wat ruimer standpunt verdedigd. Vgl. Rb. Dordrecht 10 februari 1988 , NJ 1989, 830. Het kopje van deze verder niet gepubliceerde uitspraak luidt onder andere: "Ook indien in de statuten goedkeuringshevoegdheid op de navolgende gebruikelijke punten (..) ontbreekt, geeft dit geen aanleiding om te concluderen dat commissarissen beperkte bevoegdheden hadden en in verband daarmee een verminderde aansprakelijkheid van commissarissen zou moeten worden aangenomen." Zie ook HR 10 januari 1990, NJ 1990, 446, r.o. 10.2 (Ogem). 


\section{HET GOEDKEURINGSBESLUIT}

vereiste voor vertegenwoordigingsbevoegdheid. Gaat het bestuur de transactie aan zonder bestuursmacht te hebben, en dus zonder vertegenwoordigingsbevoegd te zijn, dan is de rechtspersoon niet gebonden. Het gebrek aan bestuursmacht brengt tweeërlei nietigheden mee. In de eerste plaats die van het bestuursbesluit waarbij tot het aangaan van de verboden transactie werd besloten, en daarnaast die van de op het besluit voortbouwende externe rechtshandeling, welke nietig is wegens strijd met de wet (art. 3:40 BW).

Anders is de situatie in het geval van art. 164. Hier kan de rechtspersoon door het bestuur worden gebonden ondanks het ontbreken van goedkeuring door de rvc. De goedkeuring van de rvc geldt hier niet als een vereiste voor de geldigheid van het bestuursbesluit. De eis van goedkeuring houdt in een op het bestuur rustende verplichting om het genomen besluit niet uit te voeren zolang commissariële toestemming niet is verkregen. Doch dit verbod van uitvoering impliceert het bestaan van een besluit dat vatbaar is voor uitvoering, en dat als zodanig dan ook perfect is. ${ }^{88}$ Indien het bestuur ondanks het ontbreken van goedkeuring niettemin tot uitvoering ervan overgaat, vervult het zijn taak onbehoorlijk en kunnen de bestuursleden, voor zover de vennootschap door de uitvoering van het besluit benadeeld wordt, persoonlijk worden aangesproken tot vergoeding van de schade. Voor wat betreft het externe element van de transactie geldt bovengenoemd verbod van uitvoering slechts ten dele. De vertegenwoordigingsbevoegdheid van het bestuur wordt niet aangetast door het ontbreken van goedkeuring. De vennootschap kan ook zonder goedkeuring worden gebonden. Het verbod van uitvoering geldt ten opzichte van het bestuur en niet jegens de wederpartij. De op het bestuursbesluit voortbouwende externe rechtshandeling wordt daarom slechts aangetast voor zover de wederpartij wist of behoorde te weten dat het verbod werd overtreden. De onrechtmatigheid van het handelen van de wederpartij bestaat dan in het schuldig, althans toerekenbaar, meewerken aan het onrechtmatig handelen van het bestuur. ${ }^{89}$

88. Zo ook L. Timmerman, Preadvies van de Vereniging Handelsrecht, 1991, blz. 73. Van Schilfgaarde (1992), nr. 144, ziet in art. 164 een verbod tot uitvoering van het bestuursbesluit, doch, zich baserend op het verband tussen stem en besluit (t.a.p., nr. 91), cordeelt hij dat het bestuursbesluit geen rechtskracht heeft. Dit is mijns inziens juist voor zover de stemmen van de bestuurders nietig moeten worden geacht, maar zulks staat op zich los van het ontbreken van goedkeuring door de rvc. Deze goedkeuring is geen vereiste voor de geldigheid van het bestuursbesluit. Evenzo Flume (1979), $\$ 54,5$.

89. De gebondenheid van de rechtspersoon staat niet bij voorbaat. vast. Gezien de aard van de in art. 164 genoemde transacties zal het wellicht eerder uitzondering dan regel zijn dat de wederpartij bedoelde wetenschap niet bezat. 
Elk goedkeuringsplichtig besluit van het bestuur zal een ad hoc goedkeuring behoeven. Een algemene goedkeuring vooraf door de rvc is niet geoorloofd. Een zodanige 'goedkeuring' kan als in strijd met de wet worden aangemerkt omdat de aard van de in de wet genoemde besluiten met zich meebrengt dat de rvc zich hic et nunc een oordeel vormt over het besluit. Een andere handelwijze zou onder normale omstandigheden duiden op verwaarlozing van de commissariële taak. De controlerende taak van de rvc, waaruit de goedkeuringsbevoegdheid voortvloeit, is geen abstracte aangelegenheid, doch ziet op concrete handelingen van het bestuur. Wel mogelijk acht ik dat, indien de omstandigheden zulks rechtvaardigen ${ }^{90}$, de rvc zijn goedkeuring verleent voordat het definitieve bestuursbesluit daar is. In dat geval heeft de rvc zich een oordeel gevormd over de betrokken transactie.

De MvT lijkt hierover anders te oordelen. Gesteld wordt: "Waar een enkel van deze besluiten tot het regelmatig bedrijf der onderneming behoort -zoals uitgifte en verkrijging van eigen aandelen bij de beleggingsmaatschappijen- kunnen commissarissen onder door hen te stellen voorwaarden een algemene goedkeuring vooraf geven. ${ }^{~}{ }^{91}$ Doch evenmin als het college van commissarissen zich bezig behoeft te houden met transacties die voor de vennootschap van te verwaarlozen belang zijn, is dit college gehouden in de uitoefening van zijn taak een "algemene goedkeuring vooraf" te verlenen voor dergelijke transacties. Een zodanige goedkeuring is zinloos en wordt door de wet naar mijn mening niet vereist. De wet spreekt weliswaar over uitgifte en verkrijging van aandelen en schuldbrieven (art. 164 lid sub $a$ ) en over medewerking aan uitgifte van certificaten (sub $b$ ), zonder een bepaald belang voor de transactie te eisen, waaruit zou kunnen worden afgeleid dat voor iedere verkrijging, etc. goedkeuring van de rvc vereist zou zijn, doch uit de overige goedkeuringsplichtige handelingen blijkt dat goedkeuring alleen noodzakelijk is met betrekking tot "ingrijpende gebeurtenissen in het bestaan van de vennootschap en in de sociale en economische verhoudingen in de onderneming. ${ }^{192}$

Slechts voor zover commissarissen in de onmogelijkheid verkeren om de goedkeuringsbevoegdheid uit te oefenen, zal het bestuursbesluit geêffectueerd kunnen worden zonder goedkeuringsbesluit van de rvc. Men denke aan fysieke onmogelijkheid van alle commissarissen of aan de situatie dat alle commissarissen een tegenstrijdig belang hebben bij de betrokken transactie dat hen belet de goedkeuringsbevoegdheid uit te oefenen.

90. Bijvoorbeeld indien het bestuur nog over de transactie dient te onderhandelen.

91. Maeijer, Wetsgeschiedenis, IXf - Art. 52n (III) -2 .

92. Aldus de MvT. Maeijer, Wetsgeschiedenis, IXf - Art. 52n (III) - 1. Over de mogelijkheid van een gecombineerde vergadering van bestuur en rve zie supra $\$$ 1,IV. 


\section{RECHT OP INFORMATIE}

Het voorgaande is mijns inziens niet wezenlijk anders wanneer het goedkeuringsrecht van de rvc niet uit art. 164 voortvloeit, doch gebaseerd is op een statutaire bepaling. Mogelijk betreft het statutaire goedkeuringsrecht minder belangrijke transacties dan die welke in de wet worden genoemd. De conclusie moet dan zijn dat de toezichthoudende taak verzwaard is. Dat deze verzwaring niet op de wet doch op een autonome beslissing van de rechtsgenoten berust, betekent niet dat zij minder verplichtend is.

Voor het goedkeuringsbesluit gelden de algemene voorschriften met betrekking tot besluitvorming. De statuten of het reglement van de rvc kunnen regels bevatten over de wijze van besluitvorming. Zolang daaruit niet anders blijkt, zal het besluit rechtsgeldig worden genomen wanneer de meerderheid van de raad voor het besluit stemt. Zolang uitoefening van de bevoegdheid door commissarissen in vrijheid geschiedt, kan de stemming ook geschieden in een gecombineerde vergadering met het bestuur. ${ }^{93}$

\section{$\S 10$. Recht op informatie}

De vervulling van de commissariële taak en de uitoefening van de daarbij behorende bevoegdheden veronderstellen kennis van de onderwerpen waarop deze taak en bevoegdheden betrekking hebben. ${ }^{94}$ Hieruit is de noodzaak van informatieverschaffing aan de rvc, als ook het recht op deze informatie van de rvc, te verklaren. Daarmee is tevens het kader aangegeven waarbinnen de informatievoorziening moet plaatsvinden, namelijk binnen de uitoefening van de commissariële taak. ${ }^{95}$ Wanneer de wet bepaalt dat het bestuur aan de rvc de voor de uitoefening van diens taak noodzakelijke gegevens dient te verstrekken (art. 141), spreekt zij duidelijker taal dan de MvT, waarin te dezer zake wordt opgemerkt dat commissarissen "uiteraard binnen de grenzen der redelijkheid"96 informatie aan het bestuur kunnen vragen.

Uit de relatie tussen taakuitoefening en informatie volgt dat de rvc niet alleen bevoegd is om informatie te verkrijgen, doch dat hij ook verplicht is zich die informatie te doen verschaffen voor zover zulks noodzakelijk is

93. Anders Maeijer (1973), blz. 25.

94. Zie in het algemeen over enkele praktische punten van het informatierecht van commissarissen Y.L.L.A.M. Delfos-Roy, Toetsing en vergaring van informatie door de raad van commissarissen, TVVS 1992, blz. 224 e.v.

95. In gelijke zin Van der Burg, TVVS 1982, blz. 242; Van Leeuwen, diss. (1990), blz. 99.

96. Maeijer, Wetsgeschiedenis, IXf - Art. 50a (II) - 1 . 


\section{BEVOEGDHEDEN VAN DE RAAD VAN COMMISSARISSEN}

voor een behoorlijke taakvervulling. Het niet voldoen aan deze verplichting levert onbehoorlijke taakvervulling zijdens de rvc op. ${ }^{97}$

Ook aan de algemene vergadering kent de wet een recht op informatie toe (art. 107 lid 2). De verplichting tot informatieverschaffing rust op bestuur en rvc. Het informatierecht van de ava heeft een ander karakter dan dat van de rvc. Dit volgt uit het verschillend karakter van beide organen. Terwijl de rvc het orgaan is dat toezicht houdt op het bestuursbeleid, beslist de ava over de wezenlijke zaken van de vennootschap. Niet geheel correct lijkt mij de stelling dat het "informatie-recht van de raad verder [gaat] dan dat van de aandeelhoudersvergadering ${ }^{198}$, omdat het verschil in informatie niet zozeer te maken heeft met de hoeveelheid van te verstrekken gegevens, als wel met de gerechtigdheid tot die gegevens. Voorzover de ava het vennootschappelijk beleid niet in detail bepaalt, heeft zij concrete informatie niet nodig. Dit in tegenstelling tot de rvc, die in de uitoefening van zijn controlerende taak niet kan volstaan met een oppervlakkige kennis van de bestuursplannen. De ava kan echter alle gegevens vragen die haar noodzakelijk lijken voor een correcte besluitvorming. Omdat het hierbij gaat om de uitoefening van een eigen bevoegdheid, is de ava autonoom in de beoordeling van de noodzakelijkheid van de informatie. De wet bepaalt dat bestuur en rvc de gevraagde informatie kunnen weigeren indien "een zwaarwichtig belang der vennootschap" zich tegen verschaffing verzet (art. 107 lid 2). Daar het vennootschappelijk belang mijns inziens gelijk staat met het rechtmatig belang van de gezamenlijke aandeelhouders ${ }^{99}$, dient de weigering te worden gerechtvaardigd door een onrechtmatige uitoefening van het informatierecht door de ava. Het gaat er mijns inziens op zich niet om hoeveel belang de aandeelhouders hebben bij de informatie, of welke schade voor 'de vennootschap' te duchten valt, maar of de algemene vergadering haar bevoegdheid te goeder trouw uitoefent. Dit komt er op neer dat om de gevraagde informatie te kunnen weigeren, bestuur en rvc in plaats van te wijzen op het 'vennootschappelijk belang' feiten dienen aan te voeren waaruit blijkt dat uitoefening van de informatiebevoegdheid onder de gegeven omstandigheden in strijd is met de eisen van art. 8.

Ook aan individuele leden van de rvc kan mijns inziens informatie worden onthouden. Op dezelfde manier als een bestuurder een belang kan hebben dat hem (gedeeltelijk) ongeschikt maakt om de bestuurstaak uit te voeren, is het mogelijk dat een commissaris geen aanspraak kan maken op

97. HR 10 januari 1990 , NJ 1990, 466, r.o. 10.2 (Ogem), waarover, Raaijmakers, AA 1990, blz. 868 e.v. en Van Vliet WPNR 5984 (1990), blz. 803 e.v. Evenzo Rb. Breda 1 mei 1990, NJ 1990, 740 (Tilburgsche Hypotheekbank).

98. Handboek, nr. 274.

99. Hiervoor \& 4,III. 


\section{RECHT OP INFORMATIE}

informatie die op zich bij zijn taakvervulling past. ${ }^{100}$ Men denke aan het geval van een commissaris die zitting heeft in de rvc van twee elkaar beconcurrerende vennootschappen. Voor zover een behoorlijke taakvervulling vanwege het belangenconflict blijvend onmogelijk is, zal de betrokken commissaris zijn ambt dienen neer te leggen.

Ook terzake van het informatierecht geldt het collegialiteitsbeginsel. Het recht op informatie komt toe aan het college van commissarissen, niet aan het individuele lid. ${ }^{101}$ De raad beslist eveneens over de noodzaak van de informatie en over de wijze van uitoefening van zijn bevoegdheid. ${ }^{102}$ Niet noodzakelijk lijkt mij an de bevoegdheid van commissarissen tot informatievergaring een nadere statutaire basis te geven. Het recht op informatie komt aan de rvc krachtens de wet toe. Wanneer het informatie recht statutair nader zou worden bepaald, loopt men het risico in dit recht een soort attributie krachtens besluit van de ava te zien. ${ }^{103}$

Een zekere plicht tot informatieverstrekking kan ook op de rvc rusten krachtens art. 24 WOR. Dit artikel verplicht commissarissen, zo die er zijn, om deel te nemen aan de overlegvergaderingen met de or over de algemene gang van zaken binnen de onderneming. Deze vergaderingen vinden ten minste twee maal per jaar plaats. In tegenstelling tot art. 2:107 BW bevat art. 24 WOR geen expliciete informatieplicht. De overlegvergadering waarvan hier sprake is, heeft niet tot doel dat de or informatie ontvangt van de commissarissen omtrent de algemene gang van zaken in de onderneming. Niet de commissarissen maar de bestuurder is de gesprekspartner van de or. De eventueel door de rvc te verstrekken informatie zal betrekking dienen te hebben op zaken die met de toezichthoudende taak van de rvc te maken hebben. ${ }^{104}$

100. Zie $\S 3$,III en $\S 18$. In gelijke zin Van Leewwen (1990), blz. 101.

101. Evenzo Handboek, nr. 274; Van Leeuwen (1990), blz. 99. Ook de schaarse rechtspraak over het onderwerp stelt zich op dit standpunt. Zie Pres. Rb. Roermond 28 maart 1985, KG 1985, 128.

102. Hierover Van der Burg (1982), blz. 241 e.v. Het standpunt van Van Leeuwen, (1990), blz. 101, dat de rve recht heeft op scthriftelijke informatie lijkt mij in zijn algemeenheid onjuist. Dit zal van de omstandigheden afhangen. Vgl. in Duitsland, pro Lutter/Krieger, p. 67 (Grundsatz der Schriftlichkeit), contra Geßler, $\$ 90, \mathrm{Rz}$ 6.

103. Anders Maeijer (1972), blz. 33 en Lōwensteyn, Rechtspersonen, art. 141, aant. 2.

104. Nader hierover H.J.M.N. Honeé, Contacten tussen commissarissen en ondernemingsraad, Deventer 1987. 


\section{\$11. Andere bevoegdheden}

Hiervoor zijn bevoegdheden besproken die krachtens wettelijke toebedeling aan de rvc toekomen. Deze wettelijke toebedeling kan statutair worden uitgebreid waar de wet zulks toelaat. Art. 140 lid 3 geeft een algemene wettelijke grondslag voor de statutaire uitbreiding. Voorts wordt op verschillende plaatsen in de wet de mogelijkheid geopend om "andere organen", "een derde", "andere personen" bepaalde bevoegdheden toe te kennen (artt. 24, 120 lid 1, 130 lid 4, 133, 134 lid 4, 195 lid 3, etc.). Dit alles doet de vraag rijzen naar de verhouding tussen het wettelijk regime met betrekking tot toebedeling van bevoegdheden en de statutaire uitbreiding van dit regime.

Het uitgangspunt dient hier hetzelfde te zijn als terzake van de mogelijkheden tot statutaire uitbreiding van de commissariële taak. ${ }^{105}$ De vrijheid van de rechtsgenoten ontplooit zich binnen de grenzen van het recht. Omdat het vennootschapsrecht dwingend van aard is (art. 25), is deze vrijheid in die zin wezenlijk beperkt dat de rechtsgenoten aan de rvc in beginsel niet meer bevoegdheden kunnen toekennen dan dit orgaan reeds krachtens wettelijke toebedeling bezit. Zulks is slechts anders voor zover de wet geen dwingend karakter heeft of voor zover de rechtsgenoten vrij zijn om een nadere regeling te geven aan een bevoegdheid die wettelijk aan de rve toekomt. Zo bestaat de vrijheid om bepaalde bestuursbesluiten aan de goedkeuring van de rvc te onderwerpen wanneer ten aanzien van die besluiten art. 164 niet geldt. Ook kan het bevoegde orgaan binnen zekere grenzen nadere regels stellen met betrekking tot de wijze waarop het toezicht zal worden gehouden, bijvoorbeeld in dier voege dat er een gedelegeerde commissaris zal zijn.

De vraag of een bepaalde bevoegdheid aan de rvc kan worden toegekend, is gezien het voorgaande een kwestie van wetsuitleg. Het criterium voor de geoorloofdheid van de toebedeling is of de bevoegdheid in kwestie bij de wettelijke taakstelling van de rvc past. Naar mijn mening is het niet voldoende dat de wet toestaat de bevoegdheid in kwestie aan 'iemand' op te dragen. Deze 'iemand' zal de rvc, resp. een of meer commissarissen, slechts kunnen zijn voor zover de betrokken bevoegdheid dienstbaar is aan de vervulling van de toezichthoudende taak.

Illustratief in dit verband is art. 130. Volgens dit artikel kan statutair worden bepaald dat "een bestuurder de vennootschap slechts met medewerking van een of meer anderen mag vertegenwoordigen" (lid 2). Voorts wordt bepaald dat aan "andere personen" dan bestuurders vertegenwoordigingsbevoegdheid kan worden toegekend (lid 4). In de literatuur bestaat

105. Hiervoor $\S 3, \mathrm{I}$. 
verschil van mening over de vraag of toekenning van vertegenwoordigingsbevoegdheid aan de rvc of aan de afzonderlijke leden daarvan geoorloofd is. Naar het oordeel van Van der Grinten is zulks niet het geval omdat het niet in het systeem van de wet past dat aan commissarissen vertegenwoordigingsbevoegdheid wordt gegeven. ${ }^{106}$ Het departement stelt zich op hetzelfde standpunt. ${ }^{107}$ Hiertegenover stelt Van Schilfgaarde dat in het tweede lid de wettekst zich niet verzet tegen toekenning van vertegenwoordigingsbevoegdheid aan een combinatie van bestuurders en commissarissen. ${ }^{108}$ Aan Van der Grinten dient te worden toegegeven dat de vertegenwoordigingsbevoegdheid niet een bevoegdheid is die zonder meer bij de controlerende taak van de rvc past. Vertegenwoordigingsbevoegdheid is een complement van de bestuursmacht van het leidinggevende orgaan en behoort als zodanig niet tot bevoegdheidssfeer van de rvc, en dan ook evenmin tot de controlerende taak.

Ik zou echter menen dat op dezelfde manier als de bestuursmacht beperkt kan worden door middel van het commissariële goedkeuringsrecht, het mogelijk moet worden geacht dat aan een of meer leden van de rvc zeggenschap wordt gegeven in de vertegenwoordiging van de vennootschap. Mijns inziens kunnen commissarissen de aangewezen personen zijn om de vertegenwoordigingsbevoegdheid van bestuurders in de zin van het tweede lid te beperken. Voor zover de in dat lid bedoelde "anderen" functionarissen van de vennootschap zijn, zijn zij onderworpen aan de bestuursmacht van de bestuurders. Er schuilt een zekere tegenstrijdigheid in het feit dat de bestuurder in de uitoefening van zijn taak aangewezen is op de medewerking van een ondergeschikte. Mutatis mutandis geldt hetzelfde wanneer de "anderen" geen functionarissen van de vennootschap zijn. Anders is de situatie, naar mijn mening, indien de "anderen" commissarissen zijn. De toezichthoudende positie van de rvc binnen de vennootschap brengt mede dat de bestuurder bij de vervulling van een wettelijk aangewezen onderdeel van zijn taak afhankelijk kan worden gemaakt van de medewerking van een toezichthouder. In het bijzonder geldt dit wanneer de vertegenwoordigingsbevoegde toezichthouder gedelegeerd commissaris is.

Anderzijds bestaat een verschil tussen de derde zin van het tweede lid van art. 130 en het vierde lid van hetzelfde artikel. ${ }^{109}$ Terwijl de bepaling van lid 2 de vertegenwoordigingsbevoegdheid van een bestuurder beoogt te

106. Handboek, nr. 238.

107. Dep. Richtl. $\$ 10$.

108. (1992) nr. 51 .

109. De eerste bepaling luidt: "Zij (de statuten) kunnen voorts bepalen dat een bestuur-" der de vennootschap slechts met medewerking van een of meer anderen mag vertegenwoordigen." Lid 4 luidt: "De statuten kunnen ook aan andere personen dan bestuurders bevoegdheid tot vertegenwoordiging toekennen." 
beperken, houdt het vierde lid het tegenovergestelde in, namelijk toekenning van vertegenwoordigingsbevoegdheid aan anderen dan bestuurders. Terwijl eerstgenoemde bepaling dus een controlerende strekking heeft, houdt de tweede een nadere uitwerking in van de bestuursmacht van het bestuur. ${ }^{110}$ Daarom lijkt mij dat de eerste bepaling wel, doch de tweede niet in de taakstelling van de rvc past. Toekenning van vertegenwoordigingsbevoegdheid in de zin van het vierde lid aan een of meer commissarissen acht ik dan ook ongeoorloofd.

Op verschillende manieren kan de rvc, of een of meer van zijn leden, worden betrokken bij de uitoefening van vennootschappelijke bevoegdheden. Het oordeel van commissarissen kan worden gevraagd terzake van een bepaalde aangelegenheid, waarbij dit oordeel de rechtssfeer van de vennootschap kan raken. Inroeping van het commissariële oordeel kan geschieden krachtens overeenkomst of krachtens statutaire bepaling. In het eerste geval kan men denken aan een overeenkomst tussen aandeelhouders, waarbij partijen in bepaalde gevallen zich aan het oordeel van commissarissen onderwerpen. Voorbeelden van de tweede situatie zijn statutaire clausules waarbij aan commissarissen bevoegdheden worden toegekend met betrekking tot staking van stemmen binnen het bestuur of de ava (art. 120 lid 1), de vaststelling of een besluit genomen is (art. 13 lid 3), de beoordeling of een kandidaat-aandeelhouder an de statutaire kwaliteitseisen voldoet.

In beginsel gaat het bij voornoemde situaties om verschillende rechtsverhoudingen. De contractuele regelingen geven een voorziening van obligatoire aard tussen de partijen bij de overeenkomst, waarbij de vennootschap niet betrokken behoeft te zijn. De commissaris zal daarbij veelal handelen in de hoedanigheid van bindend adviseur. Daarentegen bevatten statutaire regelingen een voorziening van rechtspersonenrechtelijke aard die een bepaald aspect van de inrichting of besluitvorming van de rechtspersoon regelen. Commissarissen handelen bij de uitoefening van de bevoegdheid in kwestie als orgaan van de rechtspersoon. Een scherpe grens tussen verhoudingen van contractuele aard en zuiver vennootschapsrechtelijke verhoudingen is echter niet te trekken. Niet ondenkbaar is dat bepaalde contractuele afspraken, waarbij de vennootschap als zodanig geen partij is, niettemin voor haar bindende effecten hebben ${ }^{11}$, terwijl onder om-

110. De bestuursmacht wordt in zoverre nader geregeld dat toekenning van vertegenwoordigingsbevoegdheid bedoeld is on het bestuursbeleid te realiseren. Vgl. hierover Lowensteyn, Rechtspersonen, art. 130, aant. 7.

111. Vgl. HR 30 maart 1928, NJ 1928, 829 (Hartogh/Ulrici). Zie nader over contractuele regelingen met betrekking tot de uitoefening van vennootschappelijke bevoegdheden hierna $\$ 14, \mathrm{I}$, a. 
standigheden statutaire bepalingen obligatoire effecten kunnen sorteren. ${ }^{112}$ Op deze plaats kan niet nader op het onderwerp worden ingegaan. De gemaakte onderscheiding lijkt mij wel van belang bij de beoordeling van de vraag in hoeverre toekenning van een bepaalde bevoegdheid aan commissarissen mogelijk is. De vraag kan worden geillustreerd aan de hand van de bevoegdheid tot beslechting van geschillen. ${ }^{113}$

Voor wat betreft de contractuele regelingen bestaat in beginsel geen bezwaar tegen aanwijzing van een of meer commissarissen als onafhankelijke derden. Het oordeel van commissarissen kan worden ingeroepen om verschillen van mening onder aandeelhouders op te lossen. Of een zodanige toekenning onder alle omstandigheden wenselijk is, is een andere vraag. Bij een aandeelhoudersovereenkomst bijvoorbeeld kan, hoewel de commissaris niet q.q. maar als adviseur handelt, een onafhankelijke taakvervulling als commissaris in gevaar worden gebracht door zijn bemoeienis met de zaken van de aandeelhouders.

Ten opzichte van statutaire regelingen geldt mijns inziens het hiervoor aangehaalde criterium dat statutaire toekenning van de bevoegdheid om geschillen te beslechten alleen geoorloofd is voor zover zulks dienstbaar is aan de toezichthoudende taak van de rvc. Omdat dit toezicht tot onderwerp heeft het door het bestuur bepaalde vennootschappelijk beleid, zal de beslechting van geschillen binnen het bestuur eerder als uitvloeisel van de controlerende taak dienen te worden beschouwd dan de beslechting van geschillen binnen de ava. Indien aan commissarissen krachtens art. 120 lid 1 de bevoegdheid wordt toegekend om een impasse binnen de algemene vergadering te doorbreken ${ }^{114}$, helpen commissarissen bij de vorming van de vennootschappelijke wil. Een dergelijke medewerking aan de vorming van de vennootschappelijke wil valt mijns inziens niet te rangschikken onder de taak die art. 140 op commissarissen legt. Anderzijds lijkt mij de betrokken clausule, gezien de omstandigheden waarin de vennootschap bij toepasselijkheid van art. 120 lid 1 zich bevindt, niet zonder meer in strijd met het wettelijk systeem. Indien de algemene vergadering niet tot een

112. In dit verband kan worden gewezen op het arrest van het Europese Hof van Justitie van 10 maart 1992, zaak C-214/89 (Duffrijn/Petereit). "Il en résulte qu'une clause attributive de jurisdiction figurant dans les statuts d'une societé anonyme constitue une convention au sens de l'article 17 de la convention de Bruxelles liant l'emsemble des actionnaires". Ook andere verhintenissen, bijvoorbeeld tot betaling van een geldsom, die hun grondslag vinden in de statuten van een rechtspersoon worden door het Hof aangemerkt als verbintenissen uit overeenkomst in de zin van art. 5 lid I EEX-verdrag. Zie HvJ 22 maart 1983, zaak 34/82, NJ 1983, 644 (Peters/Zuid Nederlandse Aannemersvereniging).

113. Hierover Westbroek, De NV 61 (1983), blz. 13 e.v.

114. Vgl. over deze mogelijkheid Handboek, nrs. 219 en 279; Dortmond, WPNR 5410 (1977), blz. 461 e.v. en Westbroek (1982), blz, 15 e.v. 
besluit kan komen, is het mogelijk de stem van commissarissen niet zozeer te zien als een meewerken aan de vorming van de vennootschappelijke wil, doch veeleer als een überhaupt meewerken aan de totstandkoming van een vennootschappelijke wil. Ten einde de vennootschap uit de impasse te halen kan het geoorloofd zijn de rvc een beslissende stem te laten uitbrengen. Deze bevoegdheid dient dan aan het orgaan als college -en niet aan een of meer van zijn leden- te worden toegekend. Wordt een bepaalde commissaris met name genoemd, dan zou ik willen aannemen dat zijn handelen als "derde" in de zin van art. 120 lid 1 niet is een handelen als toezichthouder, in de hoedanigheid van commissaris, doch een handelen als bindend adviseur. ${ }^{115}$

115. Dortmond (1977), blz. 646 stelt zich op een soortgelijk standpunt wanneer de aangewezen "derde" een aandeelhouder is. De aandeelhouder handelt volgens hem niet als zodanig maar in een bepaalde hoedanigheid (naar ik meen, die van adviseur). 


\section{HOOFDSTUK III}

\section{Samenstelling van de raad van commissarissen}

De uitoefening van bevoegdheden in het rechtspersonenrecht is mensenwerk. De ambten in rechtspersonen worden in de regel door natuurlijke personen bekleed. Voor zover niet- natuurlijke personen maar rechtspersonen zitting hebben in de organen, geldt dat ook in deze rechtspersonen de bevoegdheden uiteindelijk door mensen worden uitgeoefend. Voor de uitoefening van de aan het ambt verbonden bevoegdheden -en daarmee voor de vervulling van de taak waartoe deze bevoegdheden zich richtendragen de orgaanbemanners een zekere verantwoordelijkheid.

Dit hoofdstuk gaat over de samenstelling van de rvc. Aan de orde zullen achtereenvolgens komen: de rechtspositie van de commissaris, zijn benoeming, schorsing en ontslag, en de samenstelling van de raad. Tot slot worden enkele bijzondere gevallen behandeld.

Voor wat betreft de bevoegdheid tot benoeming, schorsing en ontslag van commissarissen is gekozen voor een gescheiden behandeling van het gewone en het structurregime. Een aparte behandeling ligt voor de hand ondat de bevoegde instanties en de te volgen procedures in de twee regimes in belangrijke mate verschillen.

\section{$\S 12$. Aard van de rechtsverhouding tussen commissaris en vennootschap}

Evenals bij de bestuurder het geval was, rijst bij de commissaris de vraag naar de aard van zijn rechtsverhouding tot de vennootschap. In het algemeen kan worden gesteld dat rechtspraak en doctrine uitgaan van het bestaan van één samengestelde rechtsverhouding van contractuele en 
vennootschapsrechtelijke aard. ${ }^{1}$ Een zekere evolutie heeft in zoverre plaatsgevonden dat in de oudere rechtspraak en literatuur de verhouding als een arbeidsovereenkomst werd aangemerkt. ${ }^{2}$ Thans dient reeds op grond van art. 160, sub $a$ te worden aangenomen dat zulks niet het geval kan zijn. Immers, het is niet alleen mogelijk, maar bij structuurvennootschappen zelfs noodzakelijk, dat een commissaris geen werknemer in dienst van de vennootschap is. Het algemene standpunt in de literatuur is dat tussen commissaris en vennootschap een overeenkomst tot het verrichten van enkele diensten of opdracht bestaat. ${ }^{3}$

Mijns inziens miskent deze leer de eigen aard van de vennootschappelijke relatie tussen commissaris en vennootschap. De stelling dat in deze relatie steeds een contractueel element aanwezig is, lijkt mij in haar algemeenheid onjuist. Het bestaan ervan kan niet a priori worden aangenomen doch dient in ieder concreet geval te worden vastgesteld. Paradigmatisch is het standpunt van Glasz: "Voor de commissaris treedt het takenpakket in werking met zijn benoeming. En die benoeming stoelt op een overeenkomst tussen de commissaris en de rechtspersoon (...) In het systeem der wet stoelt de rechtsverhouding tussen commissarissen en vennootschap op 'een overeenkomst tot het verrichten van enkele diensten'. ".4 Rechtens stoelt de benoeming tot commissaris, anders dan aangehaalde schrijver stelt, niet op enigerlei overeenkomst. Benoeming is een abstracte rechtshandeling van rechtspersonenrechtelijke aard, welke handeling, na aanvaarding van het benoemingsaanbod door de kandidaat, de verhouding tussen commissaris en vennootschap doet ontstaan..$^{5}$ Als lid van de rvc maakt de commissaris deel uit van de vennootschap. Zijn vennootschapsrechtelijke positie wordt bepaald door wet en statuten en niet door contractuele afspraken met de

1. Vgl. Handboek, nr. 282; N.J.P. Giltay Veth, De rechtspositie van bestuurder en commissaris bij NV en BV, Offerhauskring 25 jaar, Deventer 1987, blz. 64 e.v. en de aldaar genoemde rechtspraak.

2. Vgl. de auteurs geciteerd door Kamphuisen, De NV 22 (1943-44), blz. 181. Als werknemer wordt de commissaris nog kennelijk angemerkt door Lowensteyn, Rechtspersonen, art. 142, aant. 7. In fiscalibus is er sprake van een fictieve dienstbetrekking (art. 3 lid 1 sub $h$, Wet op de Loonbelasting).

3. In deze zin Handboek, nr. 282; Van Schilfgaarde (1992), nr. 71; Raaijmakers (1991), blz. 173-174, waarbij niet steeds duidelijk is of er sprake is van van én samengestelde rechtsverhouding, dan wel van twee verschillende verhoudingen en in dit laatste geval hoe deze zich verhouden.

4. (1992), blz. 7. Curs. ook in het origineel.

5. Anders ook dan Lowensteyn, Rechtspersonen, art. 142, aant. 7, stelt, impliceert de noodzaak van aanvaarding van het benoemingsaanbod mijns inziens niet dat benoeming een tweezijdige rechtshandeling is. Aanvaarding kan worden verstaan als vereiste voor de geldigheid van de benoeming. 


\section{RECHTSVERHOUDING COMMISSARIS-VENNOOTSCHAP}

rechtspersoon waarvan hij deel uitmaakt. ${ }^{6}$

Dat de benoeming van de commissaris niet op een overeenkomst berust, blijkt wanneer de benoemingsbevoegdheid aan een 'buitenstaander' toekomt. Op grond van art. 143 kan een derde deel van de commissarissen door een in de statuten aangewezen instantie worden benoemd. Deze instantie kan zijn een andere rechtspersoon, een openbaar lichaam, etc. De gebondenheid van de rechtspersoon aan de door de 'buitenstaander' verrichte benoeming en het contractuele karakter van de verhouding tussen vennootschap en commissaris worden door Van der Grinten als volgt verklaard: "De statutaire bevoegdheid van de buitenstaander om een bestuurder [commissaris; JMBF] van de rechtspersoon te benoemen, houdt in de verlening van vertegenwoordigingsbevoegdheid van de rechtspersoon. Met deze constructie wordt bereikt, dat de verhouding van de door een 'derde' benoemde bestuurder tot de rechtspersoon als een contractuele verhouding wordt geduid."

Het komt mij echter voor dat aan deze visie haken en ogen zitten. In de eerste plaats is het niet in te zien waarom reeds het enkele feit dat de 'buitenstaander' als vertegenwoordiger van de rechtspersoon optreedt, medebrengt dat de verhouding tussen rechtspersoon en commissaris contractueel van aard is. Bovendien is het de vraag of men hier wel te maken heeft met een vertegenwoordigingskwestie in de gebruikelijke zin. Vertegenwoordigingsbevoegdheid impliceert doorgaans de aanwezigheid van een 'derde' (de vertegenwoordiger; i.c. de 'buitenstaander') die de macht heeft om rechtshandelingen te verrichten die rechtens aan de vertegenwoordigde kunnen worden toegerekend. In deze zin is het begrip vertegenwoordigingsbevoegdheid, toegepast op de organen van de rechtspersoon, niet geheel correct omdat de organen strikt genomen geen 'derden' zijn ten opzichte van de rechtspersoon: veeleer maken zij deel van hem uit. ${ }^{8}$ Dit blijkt vooral wanneer de rechtshandeling in kwestie zich binnen de sfeer van de rechtspersoon afspeelt, dat wil zeggen wanneer geen 'echte' derden betrokken zijn bij de rechtshandeling (bijvoorbeeld bij een statutenwijziging). Voor de hoedanigheid van orgaan, en dus om besluiten te nemen die voor de rechtspersoon bindend zijn, is het hebben van vertegenwoordigingsbevoegdheid in bovenbedoelde zin niet noodzakelijk. $\mathrm{Nu}$ is het wel zo dat, zoals Van der Grinten (t.a.p.) stelt, de Hoge Raad in de zaak Hersteld Apostolische Zendingsgemeente ${ }^{9}$ er vanuit ging dat een

6. In deze zin reeds Kamphuisen, De NV 22 (1943-44), Verzameld Werk, blz. 481 e.v. Vgl. ook voor Duitsland Geßler, $\$ 101, \mathrm{Rn} 50$ e.v., alwaar volgens schrijver dit standpunt geen heersende leer is.

7. Asser-Van der Grinten $I$, nr. 110.

8. Vgl, hierover met name Flume (1983), blz. 377.

9. HR 6 april 1951, NJ $1951,665$. 
bepaalde instantie, die tot benoeming van een bestuurder bevoegd was, niet als orgaan was aan te merken omdat de benoemingsbevoegdheid "niet behoeft in te sluiten dat [de benoemende instantie; JMBF] daarbij als vertegenwoordiger der vereniging optreedt." Echter, door A-G Eggens ${ }^{10}$ en door annotator Houwing ${ }^{11}$ wordt terecht opgemerkt dat de hoedanigheid van orgaan niet bepaald wordt door de bevoegdheid tot vertegenwoordiging van de rechtspersoon, doch door de macht om de wil van het orgaan rechtens als wil van de rechtspersoon te laten gelden. Strikt genomen moet men er vanuit gaan dat bij de organen het hebben van vertegenwoordigingsbevoegdheid in de gebruikelijke zin eerder uitzondering dan regel is. Alleen immers aan het bestuur komt de macht toe om de rechtspersoon jegens derden, dat wil zeggen jegens buiten de vennootschap staande personen, te binden. Het orgaanbegrip heeft daarentegen primair een 'interne' functie en duidt op het hebben van zeggenschap binnen de rechtspersoon. Welnu, de benoeming van een commissaris door een 'buiten de rechtspersoon staande derde' is niet een door een vertegenwoordiger verrichte vertegenwoordigingshandeling in de gebruikelijke zin, maar een besluit van een orgaan van de rechtspersoon. De 'buitenstaander' handelt bij de benoeming niet als derde-vertegenwoordiger maar als orgaan van de rechtspersoon. De benoemingsbevoegdheid is een 'eigen' recht van de 'buitenstaander', dat inhoudt dat zijn benoemingswil als wil van de vennootschap geldt. ${ }^{12}$ Voor zover de wil van de 'buitenstaander' aan de

10. Blz. 1302 .

11. Blz. 1304-1305.

12. Dat de benoemingsbevoegde 'buitenstaander' orgaan van de rechtspersoon is, wordt door Van der Grinten eveneens bestreden. Hij (De NV 57 (1979), blz. 141), stelt: "Deze personen behoren niet tot de organisatie van de rechtspersoon; zij zijn niet een instantie binnen de rechtspersoon; zij zijn anderen -derden- aan wie enige bevoegdheid ten aanzien van de rechtspersoon is gegeven. Het orgaan van artikel 13 [vergelijkbaar met het huidige art. 14 lid 1; JMBF] is een institutie die binnen de rechtspersoon besluiten neemt." Mijns inziens valt rechtens niet een onderscheid te maken tussen organen die "binnen" of "buiten" de rechtspersoon staan. Beslissend voor het zijn van orgaan is, zoals Van der Grinten terecht stelt, de bevoegdheid om besluiten te nemen die aan de rechtspersoon kunnen worden toegerekend. Deze bevoegdheid zal berusten op de wet of op de statuten. Zodra deze bevoegdheid bestaat zijn er, voor zover ik kan zien, geen termen om de bevoegde persoon of instantie "buiten" de rechtspersoon te plaatsen. Zo ook $P$. van Schilfgaarde, Boekbespreking Asser-Van der Grinten II (De Rechtspersoon) 5e druk, De NV 59 (1981), blz. 11. Dat het onderscheid tussen "binnen"- en "buitenvennootschappelijke" organen rechtens onhoudbaar is blijkt mijns inziens uit hetgeen Van der Grinten verderop stelt: "Bij toekenning van bevoegdheden aan bepaalde met name genoemde personen moeten als regel deze personen als derden worden beschouwd. Bij toekenning van bevoegdheden aan colleges die krachtens de statuten van een

(Wordt vervolgd...) 
rechtspersoon wordt toegerekend, kan van een vertegenwoordigingshandeling worden gesproken. Echter, de verklaring in termen van vertegenwoordiging in de gebruikelijke zin schiet tekort omdat het handelen van de 'buitenstaander' meer inhoudt dan het enkel toerekenen van zijn benoemingswil aan de vennootschap. Rechtens houdt zulks in dat de handeling van de 'buitenstaander' niet door de normale vertegenwoordigingsregels wordt beheerst maar door de regels met betrekking tot besluitvorming.

Dat de verhouding tussen commissaris en vennootschap niet een contractuele is, laat zich illustreren aan de hand van de honoreringsregeling. ${ }^{13}$ Wanneer de verhouding tussen commissaris en vennootschap als een contractuele zou worden aangemerkt, zou de beloning van de commissaris dienen te worden gezien als een op de vennootschap rustende schuld jegens de commissaris, voortvloeiende uit de tussen partijen bestaande contractuele verhouding (bijvoorbeeld een overeenkomst tot het verrichten van enkele diensten). De beloning zou dan zijn een door partijen overeengekomen regeling welke slechts met wederzijds goedvinden zou kunnen worden gewijzigd. Onze wet stelt zich echter op een ander standpunt. De vergoeding die de commissaris ontvangt voor zijn werkzaamheden is een door de vennootschap eenzijdig vastgestelde beloning. ${ }^{14}$ Art. 145 bepaalt: "Tenzij de statuten anders bepalen, kan de algemene vergadering van aandeelhouders aan de commissarissen als zodanig een bezoldiging toekennen." Met betrekking tot de overeenkomstige bepaling omtrent honorering van bestuurders (art. 135) merkt Van der Grinten op: "De wet gaat ervan uit, dat de bezoldiging van de bestuurder eenzijdig vanwege de vennootschap

12.(...vervolg)

rechtspersoon bestaan, kan van een orgaan worden besproken." Hoe zou dan een bepaling in de statuten van een stichting (dit is het voorbeeld dat schrijver zelf aanhaalt, t.a.p. en Asser-Van der Grinten II, nrs. 37 en 472) moeten worden beoordeeld die luidt: "De raad van toezicht benoemt het bestuur. De raad van toezicht bestaat uit de heer X." Het zijn van orgaan wordt niet bepaald door de naam die statutair wordt gegeven aan de bevoegde instantie doch door het hebben van de bevoegdheid.

Het voorgaande impliceert overigens niet dat elke instantie die zeggenschap heeft in aangelegenheden van de rechtspersoon orgaan is. De competentie van de OK om een commissaris van een structuurvennootschap te ontslaan, bijvoorbeeld, maakt de OK niet tot vennootschapsorgaan. De beschikking van de $\mathrm{OK}$ is een daad van het openbaar gezag op grond van de wet en geen besluit van de rechtspersoon.

13. Zie over het onderwerp in het algemeen Van der Grinten, De NV 38 (1960-61), blz. 73 e.v.; id., De NV 50 (1972-73), blz. 30 e.v.; Slagter, TVVS 1972, blz. 111-112; Gilthay Veth, TVVS 1972, blz. 145 e.v.; Timmerman, Rechtspersonen, art. 158 , aant. 18.

14. Aldus ook Van der Grinten, De NV 38 (1960-61), blz. 73. 
wordt vastgesteld. "15 Dit lijkt mij ook de juiste visie. Dat de beloning, zo die er is, feitelijk een gevolg is van overleg tussen commissaris en vennootschap, is onvoldoende grond om aan te nemen dat zij dus uit overeenkomst ontstaat. De op de vennootschap rustende honoreringsplicht vindt zijn grondslag in het benoemingsbesluit. Doch op dezelfde manier als de kandidaat-commissaris vrij is om de benoeming te anvaarden of te verwerpen, is hij vrij zulks onder bepaalde voorwaarden te doen. Een van die voorwaarden kan zijn dat de commissaris voor zijn werkzaamheden een bepaalde vergoeding zal ontvangen. Dat de vennootschap het benoemingsbesluit mede onder de voorwaarden neemt die door de commissaris zijn gesteld, maakt, zoals gezegd, van het besluit geen overeenkomst. Wanneer Van der Grinten dan ook aan zijn zojuist aangehaalde stelling toevoegt: "Nodig is dit echter niet. Het bedrag van de bezoldiging kan deel uitmaken van de overeenkomst van de bestuurder met de vennootschap, in welk geval de bezoldiging door partijen gezamenlijk wordt vastgesteld", onderscheidt hij mijns inziens onvoldoende tussen datgene waartoe de vennootschap verplicht is uit hoofde van een door haar genomen besluit (en daar heeft art. 135 betrekking op) en datgene waartoe de vennootschap gehouden is op grond van een eventueel bijkomend contract met de bestuurder, bijvoorbeeld een arbeidsovereenkomst.

De kwalificatie van de beloningsregeling, en in het algemeen van de verhouding tussen commissaris en vennootschap, als een verhouding van rechtspersonenrechtelijke aard, en niet als een overeenkomst, heeft rechtsgevolgen. Indien men zou aannemen dat de beloning een contractuele verhouding betreft, dan zou de bevoegdheid voor de toekenning van de beloning bij het bestuur dienen te berusten. Dit is immers het orgaan dat de vennootschap dient te leiden en te vertegenwoordigen. Onze wet bepaalt echter dat de toekenning van het salaris van de commissaris een bevoegdheid is die bij de ava berust tenzij statutair anders is bepaald. Een door het bestuur onbevoegdelijk toegekende beloning is derhalve nietig.

Het spreekt voor zich dat de macht van de vennootschap om de beloning eenzijdig vast te stellen niet per se de macht inhoudt om de toegekende beloning te allen tijde in te trekken. Of dit mogelijk is hangt af van de inhoud van het besluit waarbij de beloning wordt toegekend. Is in het besluit niets bepaald, dan kan de vennootschap te allen tijde de beloning wijzigen of staken. ${ }^{16}$ Wijziging en staking is mogelijk omdat de commissaris uit hoofde van zijn ambt geen recht op beloning heeft. Deze is een

15. Handboek, nr. 251.

16. Ook wanneer beloning in de vorm van een statutair vastgestelde tantieme geschiedt, behoudt de vennootschap de vrijheid om de statuten -en daarmede het tantieme- te wijzigen, voor zover de vennootschap zich het recht voorbehoudt om de statuten op dit punt te wijzigen (art. 122). Zo ook Handhoek, nr. 344. 
toekenning van de vennootschap. Anders is de situatie indien bij het benoemingsbesluit of op een later tijdstip aan de commissaris een bepaalde vaste vergoeding wordt toegekend. Aan deze toekenning is de vennootschap gebonden. Eenzijdige intrekking of wijziging maakt haar schadeplichtig. ${ }^{17}$

Het voorgaande wil niet zeggen dat, nu de rechtspositie van de commissaris niet van contractuele aard is, er in het geheel geen overeenkomst tussen commissaris en vennootschap zou kunnen bestaan. Het zijn van commissaris is op zich geen beletsel om met de vennootschap te contracteren. Voor zover de functievervulling daardoor niet wordt belemmerd, bestaat bijvoorbeeld geen bezwaar tegen overeenkomsten waarbij de commissaris als deskundige advies verstrekt terzake van vennootschappelijk aangelegenheden die buiten zijn adviserende taak ex art. 140 vallen. Daarbij handelt hij echter niet als commissaris maar als deskundige. Zijn vennootschapsrechtelijke verhouding blijft door een zodanige overeenkomst onaangetast. De commissaris kan in deze functie defungeren, doch hij zal zijn hoedanigheid van adviseur behouden, zolang althans contractueel niet anders is bedongen. De contractsvrijheid van de commissaris is slechts in zoverre beperkt dat de inhoud van de overeenkomst, namelijk de prestaties waartoe partijen zich verbinden, niet mag bestaan uit de rechten en plichten die het onderwerp uitmaken van de vennootschappelijke verhouding. Zo zou het, naar mijn mening, ongeoorloofd zijn dat de commissaris als adviseur van de vennootschap zou worden gecontracteerd ter zake van dezelfde onderwerpen als die waarvoor hij op grond van art. 140 gehouden is de vennootschap te adviseren. Een zodanige overeenkomst is in zoverre niet bestaanbaar dat de commissaris zich contractueel niet jegens dezelfde partij kan verplichten tot datgene waartoe hij reeds gehouden is krachtens de aanvaarding van zijn ambt. Eventuele vergoedingen die de commissaris voor zijn adviserende werkzaamheden zou ontvangen, zijn mijns inziens als schenkingen c.q. als onverschuldigd betaald aan te merken. Wanneer een dergelijke overeenkomst reeds vóór de benoeming van kracht zou zijn, dient de overeenkomst gedurende de functieperiode te worden opgeschort of dient zij te worden ontbonden. ${ }^{18}$

Van voornoemde overeenkomsten dienen te worden onderscheiden contracten die de wijze van uitoefening van zekere bevoegdheden onder bepaalde omstandigheden regelen. Men denke aan de overeenkomst waarbij commissarissen zich verplichten om het oordeel van een deskundige in te

17. $\mathrm{Vgl}$. Rb. Amsterdam 23 november 1925, NJ 1926, 526 en Rb. Maastricht 1 december 1960, NJ 1962, 152.

18. Vgl. in het Duitse recht, $M$. Lutter / T. Kremer, Die Beratung der Gesellschaft durch Aufsichtsratsmitglieder. Bemerkungen zur Entscheidung BGHZ 114, $127 \mathrm{ff}$, ZGR 1992, blz. 87 e.v. 
roepen wanneer er een impasse zou ontstaan in de besluitvorming binnen de raad. Deze overeenkomsten hebben een meer beperkte strekking. Zij bouwen voort op een bestaande vennootschapsrechtelijke verhouding en zien slechts op de uitoefening van vennootschappelijke bevoegdheden in concrete, met name genoemde situaties. ${ }^{19}$

Aldus is er geen grond om aan te nemen dat de verhouding tussen commissaris en vennootschap steeds een contractueel karakter heeft. ${ }^{20}$ Ook de bepalingen van art. 144 en 149 impliceren niet dat er sprake dient te zijn van een overeenkomst. Deze artikelen houden slechts een bijzondere voorziening in -te weten verbod van herstel van de dienstbetrekking (art. 144 jo. 134), resp. attributie van competentie inzake "de overeenkomst tussen de vennootschap en de commissaris" (art. 149 jo. 131)- voor zover er sprake zou zijn van een overeenkomst. Er zijn onvoldoende termen aanwezig om te concluderen dat deze voor bestuurders geschreven bepalingen, die van overeenkomstige toepassing op commissarissen worden verklaard, de aard van de rechtsverhouding tussen commissaris en vennootschap zouden duiden. ${ }^{21}$ Indien men voorts, in navolging van de Hoge $\operatorname{Raad}^{22}$, de eigen aard van de vennootschapsrechtelijke verhouding van de

19. Vgl. HR 30 maart 1928, NJ 1928, hlz. 829, waar de Hoge Raad, na te hebben gesteld dat contracten over de uitoefening van de commissariale bevoegdheden niet per se ongeoorloofd behoeven te zijn, overweegt: "... dat toch met name verplichtingen als waarom het hier gaat, - tot bijeen roepen van een algemene vergadering (...) - zonder bedenking mogen worden opgenomen onder de contractuele verplichtingen van commissarissen, indien - gelijk hier - de overeenkomst strekt om moeilijkheden in den boezem der N.V. gerezen tusschen commissarissen eenerzijds en den directeur anderzijds in dier voege op te lossen, dat commissarissen zich uit de N.V. terug trekken en de directeur hun belangen daarin en die van de achter hen staande groep van aandeelhouders overneemt." Zie verder over deze problematiek onder \& 14,I,a).

20. Lowenstcyn, Rechtspersonen, art. 142, aant. 10, doet zijn stelling dat i.c. sprake is van een contractuele verhouding mede steunen op HR 14 mei 1948, NJ 1948, 458. Het arrest biedt echter geen steun voor deze stelling. Over de aard van de verhouding laat de Hoge Raad zich niet uit. Het Hof stelt dat de aansprakelijkheid van commissarissen op onrechtmatige daad berust, terwijl volgens eiser in cassatie de aansprakelijkheid gegrond is op schending van de contractuele verplichtingen van de betrokken commissaris. Deze "contractuele" verplichtingen zijn echter de eigenlijke verplichtingen uit het lidmaatschap van de rvc, of, zoals onderdeel $a$ van het middel stelt: "... contractuele verplichtingen jegens HGB [de vennootschap; JMBF] te weten als commissaris" (mijn curs.). Dit zijn derhalve de verplichtingen uit de vennootschappelijke verhouding, welke verhouding in 1948 als lastgeving werd aangemerkt (zie blz. 764, r.k.).

21. Zie in soortgelijke zin Handboek, nr. 282. Anders Lswensteyn, Rechtspersonen, art. 142, aant. 7 .

22. HR 13 november 1992, NJ 1993, 265 (Levison). 


\section{BENOEMING (GEWONE MODEL)}

bestuurder onderkent, moet worden aangenomen dat hetgeen op dit punt voor bestuurders geldt, ook voor commissarissen geldt. Hun verhouding tot de vennootschap is dan ook niet van contractuele aard.

\section{$\$ 13$. Het gewone model}

\section{Benoeming van commissarissen}

De wettelijke benoemingsregeling geeft geen aanleiding tot een uitgebreide behandeling van het onderwerp. Op deze plaats zou ik slechts enkele omstreden kwesties willen bespreken.

Benoeming van commissarissen vindt in het gewone model plaats door de algemene vergadering, of, indien commissarissen bij oprichting worden benoemd, bij de akte van oprichting (art. 142 lid 1). De wet bepaalt dat bij een aanbeveling of voordracht tot benoeming een aantal gegevens omtrent de kandidaat moet worden medegedeeld alvorens de ava tot benoeming overgaat. Voorts dienen de redenen voor de aanbeveling of voordracht te worden medegedeeld. De vraag rijst of het achterwege blijven van deze gegevens, dan wel het verstrekken van onjuiste gegevens, de geldigheid van de voordracht, en daarmede van het benoemingsbesluit, aantast. Erkend moet worden dat het praktische belang van de vraag beperkt is. De mede te delen gegevens zijn: de leeftijd en het beroep van de kandidaat, het aantal aandelen in de vennootschap dat hij houdt en de functies die hij bekleedt of bekleed heeft en die van belang zijn voor het commissariaat. Het is moeilijk voorstelbaar dat omtrent deze gegevens onduidelijkheid bestaat. Onder normale omstandigheden zal de juistheid van de informatie eenvoudig kunnen worden vastgesteld. Wellicht kan er twijfel ontstaan over de vraag of een bepaalde betrekking van de kandidaat van belang is voor diens taakuitoefening als commissaris. In dat geval zal de voordragende instantie er goed aan doen de betrekking kenbaar te maken. Indien over deze gegevens onjuiste informatie aan de ava zou worden verstrekt, zou het besluit mijns inziens vernietigbaar zijn op grond van art. 15 lid 1 sub a indien de informatie relevant blijkt te zijn. Voor dit standpunt pleit het feit dat art. 158 lid 6 als een vernietigingsgrond aanmerkt het niet naleven van de informatieplicht vervat in het vijfde lid van dat artikel, welk lid verplicht tot het verstrekken van de in art. 142 genoemde gegevens. ${ }^{23}$

Enigszins anders is de situatie in het geval van de motivering van de

23. Anders echter Handboek, nr. 284: "De geldigheid van de benoeming is niet afhankelijk van het doen van deze mededelingen." 
voordracht. De plicht tot motivering van de voordracht houdt niet in de plicht om de ava te overtuigen van de wenselijkheid van de benoeming. De motivering kan nogal formeel van aard zijn. Naar mijn mening wordt de geldigheid van het benoemingsbesluit alleen dan aangetast wanneer de voordragende instantie de ava opzettelijk misleidt of daarbij met grove schuld handelt. Op dit punt dient het criterium te worden gehanteerd dat door de Hoge Raad wordt gebezigd met betrekking tot de geschiktheid van een bestuurder. ${ }^{24}$ De motivering zal slechts dan niet afdoende zijn indien zij klinkklare onzin bevat. ${ }^{25}$

Een bijzondere situatie doet zich voor wanneer de OK in het kader van een enquêteprocedure één of meer personen tijdelijk tot commissaris aanstelt (art. 356 sub c). Deze aanstelling is niet een gewone benoeming in vennootschapsrechtelijke zin. Het gaat hier om een maatregel van het openbaar gezag, in het kader van een bijzondere procedure en met beperkt effect in de tijd. De wet geeft niet aan hoe ver de aanstellingsbevoegdheid van de OK zich uitstrekt. Meer in concreto rijst de vraag of de OK gebonden is aan alle voorschriften omtrent de benoeming van commissarissen die voor een normale benoeming gelden. Naar mijn mening is dit niet het geval. De aanstellingsmacht van de OK vloeit voort uit een bijzondere procedure. De maatregel heeft voorts een uitzonderlijk karakter. Gelet op deze omstandigheden zou ik willen aannemen dat de OK slechts gebonden is aan die wettelijke voorschriften die een hoger belang dienen dan het belang dat gediend is met de aanstellingsmacht. Aldus zal moeten worden aangenomen dat de OK geen rechtspersoon zal mogen aanstellen (art. 140 lid 1). Evenmin zal de $\mathrm{OK}$ aan de aangestelde commissarissen bevoegdheden kunnen onthouden die noodzakelijk zijn om hun taak te kunnen uitoefenen, bijvoorbeeld de bevoegdheid om informatie van het bestuur te ontvangen (art. 141). Daarentegen meen ik dat bijvoorbeeld de benoemingsprocedure van art. 158 niet nageleefd behoeft te worden ${ }^{26}$ Immers, het belang van betrokkenen om ter zake van de benoeming te worden gehoord, dient te wijken

24. HR 13 februari 1942, NJ 1942, 360 (Baus / De Koedoe).

25. Vgl. overigens omtrent het motiveringsvereiste de nogal relativerende opmerkingen van de Minister bij de behandeling van het amendement dat tot het vereiste geleid heeft, Maeijer, Wetsgeschiedenis, IXf-Art. 50b (II)-5: "Ik sta hier een beetje tegenaan te kijken. (...) De kwalificatie "hij is een bekend conservatief, uiterst rechts man en slaat zijn vrouw elke dag", zal er niet direct in komen. Wel komt er een gemeenplaats in de trant van: "Hij is zeer sociaal hewogen", "elke dag denkt hij aan de arbeiders; aan de kinderjuffrouw, die hem heeft grootgebracht, brengt hij nog tweemaal in het jaar een bezoek". Ik hou niet van die frases." De plicht tot 'motivering' lijkt mij eveneens kwestieus.

26. In gelijke zin Boukema, Rechtspersonen, art. 356, aant. 3. 
voor het belang van de vennootschap om uit de toestand van wanbeleid die de oorzaak is van de enquête, en dus van de aanstelling van de commissaris door de OK, te geraken.

Meer onduidelijkheid bestaat over de vraag of de aanstellingsmacht van de OK beperkt wordt doordat de statuten niet voorzien in het bestaan van een rvc. De OK heeft in eén geval ${ }^{27}$ een persoon als commissaris aangesteld zonder dat de statuten een rvc kenden. Over de mogelijkheid van een dergelijke aanstelling bestaat onzekerheid. Hierover stelt Maeijer: "Het functioneren van een commissaris binnen een statutair kader dat hierin niet voorziet (vgl. art. 50 lid 1 WvK [art. 140 lid 1; JMBF]), lijkt mij onmogelijk: ook al betreft het een commissaris die door de OK is benoemd. ${ }^{28}$ In het Handboek ${ }^{29}$ wordt echter de mogelijkheid van de maatregel verdedigd met een beroep op de bevoegdheid van de OK tot tijdelijke afwijking van de statuten (art. 356 sub d). Naar mijn mening gaat het i.c. echter niet om een afwijking van de statuten. Een afwijking zou bijvoorbeeld zijn het bevel van de OK om bestuursbesluiten boven een bepaalde bedrag te onderwerpen aan de goedkeuring van de rvc, terwijl het statutair bepaald bedrag hoger ligt dan het door de OK gestelde. Voorts gaat het niet zozeer om een statutaire afwijking, maar, zoals Maeijer terecht opmerkt, om de vraag of het überhaupt mogelijk is dat een wettelijke bepaling van dwingend recht, inhoudende dat de bevoegdhedenverdeling onder de organen statutair geregeld wordt (art. 140 lid 1), door de OK opzij wordt gezet.

Ik zou menen dat, ondanks de genoemde bezwaren, aanstelling zonder statutaire basis mogelijk is. De ratio van art. 140 lid 1 is mijns inziens dat de instelling van de rvc bij vennootschappen waarin dit orgaan niet wettelijk verplicht is, op een wilsverklaring van de oprichters/aandeelhouders berust. Zonder hun instemming is het niet mogelijk dat een toezichthoudend orgaan bestaat. Het lijkt mij dat deze wilsverklaring van de rechtsgenoten, gezien het karakter van de enquêteprocedure, de tijdelijke aard van de maatregel en de expliciete toekenning van aanstellingsmacht aan de $\mathrm{OK}$, ex lege vervangen kan worden door een uitspraak van het openbaar gezag. ${ }^{30}$ Dat statutair geen expliciete toebedeling van bevoegdheden heeft plaats gevonden, staat mijns inziens noch aan de benoeming noch aan de taakvervulling van de aangestelde commissaris in de weg. De OK kan aan de aanstelling voorwaarden verbinden, in dier voege dat aan de commissa-

27. OK 26 april 1972 , NJ 1973, 6 .

28. AA 1974, blz. 126.

29. Nr. 367.

30. Mutatis mutandis geldt hier hetgeen in het Handboek, nr. 42, wordt opgemerkt ten opzichte van de toepasselijkheid van het structuurregime: "De toepasselijkheid van de wettelijke regeling is niet afhankelijk van de statutaire voorziening." 
ris bepaalde bevoegdheden uitdrukkelijk worden toegekend. Voor zover een dergelijke toekenning niet heeft plaats gevonden, zou ik willen aannemen dat de wettelijke regeling zo veel mogelijk dient te worden toegepast. Zo bijvoorbeeld op het punt van goedkeuring van besluiten. Het komt mij voor dat, ondanks het feit dat de vennootschap niet een structuurvennootschap is $^{31}$, art. 164 analoog dient te worden toegepast. Dit is gerechtvaardigd omdat de commissariële goedkeuring van besluiten in de visie van de wetgever een passende controlemaatregel is. Een dergelijke maatregel past bij een toestand van geconstateerd wanbeleid.

\section{Schorsing en ontslag van commissarissen}

Schorsing en ontslag zijn rechtshandelingen van vennootschapsrechtelijke aard waarbij een commissaris tijdelijk onbevoegd wordt verklaard om een of meer bevoegdheden uit te oefenen respectievelijk ontzet wordt uit zijn ambt. Op dit punt bestaat geen verschil met de schorsing en het ontslag van bestuurders. ${ }^{32}$

De wet kent de bevoegdheid tot schorsing en ontslag van commissarissen toe aan de instantie die bevoegd is tot benoeming van de betrokken commissaris (art. 144 lid 1). Indien de ava bevoegd is tot het nemen van het besluit tot schorsing of ontslag, kunnen de statuten het besluit aan versterkte quorumeisen onderwerpen. Voorts is de OK bevoegd in het kader van een enquêteprocedure een of meer commissarissen te schorsen of te ontslaan (art. 356 sub $b$ ).

Schorsing en ontslag zijn maatregelen van vennootschapsrechtelijke aard. $\mathrm{Zij}$ hebben tot onderwerp de vennootschappelijke bevoegdheden van de commissaris. Schorsing en ontslag zijn eenzijdige wilsverklaringen van de rechtspersoon gericht tot de betrokken commissaris. Deze maatregelen laten eventuele contractuele verhoudingen tussen vennootschap en commissaris onaangetast. De commissaris die bijvoorbeeld tevens adviseur van de vennootschap was, blijft ook na schorsing of ontslag adviseur van de vennootschap, althans zolang niet het tegendeel is overeengekomen.

Overeenkomstig de opvatting dat tussen commissaris en vennootschap steeds een contractuele verhouding bestaat, wordt in het Handboek gesteld dat "de overeenkomst tussen vennootschap en commissaris door rechterlijk vonnis [kan] worden ontbonden in geval van wanprestatie. ${ }^{133}$ De instelling van de vordering behoort evenwel, zo wordt betoogd, niet tot de bevoegd-

31. Bij structuurvennootschappen doet zich de hier aan de orde zijnde problematiek niet voor gezien het verplichte karakter van de rvc (art. 158 lid 1).

32. Zie hiervoor $\$ 7$, II.

33. Nr. 294. 
heidssfeer van het bestuur, waardoor een ad hoc besluit van de ava vereist is. Langs deze weg zou kunnen worden bereikt dat de commissaris wordt ontslagen, ook al is er binnen de ava geen voldoende meerderheid om het ontslagbesluit te nemen maar wel om de vordering in te stellen. In deze visie zou ook mogelijk moeten worden geacht dat de overeenkomst wordt ontbonden wegens verandering van de omstandigheden (art. 6:258 BW). Echter, reeds uit het feit dat Van der Grinten het bestuur niet bevoegd acht tot het instellen van de vordering tot ontslag, en daarvoor noodzakelijk acht dat de algemene vergadering zich over het onderwerp uitspreekt, blijkt dat de verhouding tussen commissaris en vennootschap niet zonder meer als een contractuele is aan te merken. Zou het hier gaan om een 'gewone' overeenkomst, dan zou de inschakeling van de ava uit den boze zijn, nu het voeren van procedures tot de bestuurscompetentie behoort. In werkelijkheid miskent deze visie het eigen karakter van de tussen commissaris en vennootschap bestaande verhouding. Op dit punt is van toepassing hetgeen door Huizink wordt gesteld omtrent de problematiek van ontslag van een bestuurder. ${ }^{34}$ Schorsing en ontslag zijn vennootschappelijke handelingen. Daar de wet hieromtrent een uitputtende regeling bevat, is het niet mogelijk het oordeel van het bevoegde orgaan te vervangen door het rechterlijke oordeel. In navolging van Slagter ${ }^{35}$ moet worden aangenomen dat het Nederlandse recht, afgezien dan van de voorziening in het kader van een enquêteprocedure (art. 356 sub $b$ ), niet aan de rechter de macht geeft om de commissaris van een gewone vennootschap te schorsen of te ontslaan.

Evenals bij de bestuurders het geval was, rijst met betrekking tot schorsing en ontslag van commissarissen de vraag naar de betekenis van de eisen van redelijkheid en billijkheid. Op soortgelijke wijze als bij de bestuurders wordt in de literatuur aangenomen dat schorsing en ontslag van commissarissen een zakelijke rechtvaardiging behoeft. ${ }^{36}$ Deze opvatting vindt mijns inziens geen steun in de wet. Het enige wat de wet hieromtrent expliciet bepaalt is dat de rechter geen herstel van de dienstbetrekking kan bevelen. Deze bepaling geldt voor bestuurders en wordt van overeenkomstige toepassing verklaard op commissarissen (artt. 144 lid 2 jo. 134 lid 3). Ten opzichte van eerstgenoemden is deze bepaling van toepassing omdat tussen bestuurder en vennootschap niet zelden een arbeidsverhouding bestaat. $\mathrm{Nu}$ de commissaris geen werknemer van de vennootschap is (art. 160 sub a), geldt de genoemde bepaling niet voor commissarissen.

34. (1989), blz. 77-78, naar aanleiding van Rb. 's-Hertogenbosch 23 januari 1953, NJ 1954, 561.

35. (1990), blz. 267.

36. Zo Timmerman, TVVS 1987, blz. 130 (althans voor het ontslag) en Handboek, nr. 293 (althans voor de schorsing). 
De bevoegde instantie is vrij om het schorsings- of ontslagbesluit naar eigen inzicht te nemen. Dit houdt evenwel niet in dat deze vrijheid niet kan worden misbruikt. Hier gelden dezelfde vrijheid en dezelfde beperkingen als ten aanzien van schorsing en ontslag van bestuurders. Wanneer de Rechtbank Maastricht ${ }^{37}$ stelt dat een wijziging in de "samenstelling van de aandeelhoudersvergadering en de door hen nieuw te varen koers" voldoende reden is om een commissaris te ontslaan, moet dit aldus worden verstaan dat het oordeel van de bevoegde instantie niet door enige rechtvaardigingsgrond dient te worden gedragen. Het gebrek aan vertrouwen van aandeelhouders behoeft geen bijzondere rechtvaardiging. De bevoegdheid om commissarissen te ontslaan, draagt haar rechtvaardiging in zichzelf. Als enige grens geldt dat zij niet gebruikt mag worden uitsluitend om de betrokken commissaris te benadelen.

Een uitspraak van de Rechtbank Utrecht kan dienen om dit toe te lichten. ${ }^{38}$ Het ging i.c. om het ontslag van twee commissarissen door de ava, welk ontslag gevolgd werd door het aftreden van andere commissarissen. Gevorderd werd vernietiging van het ontslagbesluit wegens strijd met de goede trouw. Daarnaast werd door commissarissen schadevergoeding gevorderd. De Rechtbank wijst de eerste vordering af met een beroep op het verbod van herstel van de dienstbetrekking (artt. 254 jo. 244). Volgens de Rechtbank leidt vernietiging van het ontslagbesluit tot een niet door de wet gewilde toestand. Echter de vordering tot schadevergoeding wordt toegewezen omdat de BV "wanprestatie [heeft] gepleegd in de overeenkomst tot het verrichten van enkele diensten, omdat de motieven voor het ontslag in de visie van de Rechtbank niet steekhoudend waren en bovendien onvoldoende met feiten onderbouwd waren." ${ }^{139}$ In een noot onder de uitspraak merkt Timmerman op dat de constructie van de "overeenkomst tot het verrichten van enkele diensten" nodig was om de i.c. noodzakelijk geachte schadevergoeding te kunnen toewijzen. Hij stelt: "Dit vonnis maakt duidelijk dat het niet toelaten van de toetsing van besluiten tot ontslag van een commissaris aan de goede trouw niet overtuigend te motiveren is. " ${ }^{40}$ Het niet toelaten van een dergelijke toetsing is inderdaad niet overtuigend te motiveren omdat, uitgaande van de beginselen waarop ons rechtssysteem is gebaseerd, het uberhaupt geen motivering behoeft. Principieel is de vrijheid die aandeelhouders hebben om een commissaris te benoemen of te ontslaan gelijk aan die van de eigenaar van een zaak om over zijn zaak te beschikken. Op dezelfde manier als de eigenaar zijn beschikkingsdaden niet behoeft te motiveren, en derhalve zijn daad rechtens

37. 21 april 1988, TVVS 1988, blz. 252-253.

38. Rb. Utrecht 8 augustus 1984, TVVS 1987, blz. 130, met noot Timmerman.

39. Geciteerd zoals in TVVS weergegeven.

40. TVVS 1987 , blz. 130. 
niet toetsbaar is, behoeven aandeelhouders niet te motiveren waarom zij een commissaris wensen te ontslaan. ${ }^{4 !}$ De vennootschap kan wellicht gehouden zijn tot schadevergoeding (art. 8), voor zover uit het ontslag schade voortvloeit voor de commissaris ${ }^{42}$, en een arbitrair ontslagbesluit kan mogelijk worden vernietigd, maar dit betekent niet dat de ava slechts dan zou kunnen ontslaan wanneer zij een voor de rechter aannemelijke reden tot ontslag zou kunnen aanvoeren. Gelijke vrijheid komt toe aan de instantie die bevoegd is om de vrije commissarissen te benoemen (art. 144). Wanneer echter de rvc bevoegd zou zijn tot schorsing, komt aan de raad in zoverre minder vrijheid toe dat de schorsingsbevoegdheid van commissarissen krachtens art. 140 een functioneel karakter heeft. In dat geval zal de rechter zich dienen te beperken tot een marginale toetsing van het handelen van de rvc aan het vennootschappelijk belang zoals dit door commissarissen verstaan wordt.

\section{\$14. Het structuurmodel}

\section{Benoeming van commissarissen}

In 1928 schreef Meijers: "Het is nu eenmaal een feit -en een feit, waartegen geen wetgever zich richten zal of kan- dat in tal van naamloze vennootschappen commissarissen zitten als vertegenwoordigers van bepaalde groepen van aandeelhouders of dat aandeelhouders op grond van hun aandelenbezit aanspraak hebben gemaakt op een of meer commissarissen. ${ }^{143}$ De gave van profetie is Meijers kennelijk niet ten deel gevallen. In

41. Vgl. in dit verband de opmerkingen van A-G Langemeijer in zijn conclusie voor HR 19 februari 1960, NJ 1960, 473 (Aurora). Naar aanleiding van een stemovereenkomst van aandeelhouders met een derde, waarbij de aandeelhouders zich verbonden om onder bepaalde omstandigheden de commissarissen te ontslaan stelde de A-G: "dat het onbehoorlijk kan zijn wanneer een meerderheid van aandeelhouders aan commissarissen hun functie zou ontnemen op grond van een handelwijze van deze laatsten, die de juiste vervulling van hun taak betekent" (blz. 1095, r.k.). Vervolgens stelt de $A-G$ dat wat de juiste taakvervulling inhoudt "binnen zeer ruime grenzen" ter beoordeling staat van de aandeelhouders. Ongeoorloofd kan zijn dat "de aandeelhouders zich contractueel jegens derden zouden binden om bij die beoordeling een bepaalde overweging als zonder meer beslissend te behandelen en dus hun oordeel over de behoorlijkhied van hun doen zouden uischakelen" (mijn curs. JMBF).

42. In navolging van Van der Grinten, De NV 38 (1960-61), blz. 74 en Handboek, nr. 294, moet worden aangenomen dat het ontslag van commissarissen in de regel njet tot schadevergoeding verplicht.

43. Noot onder HR 30 maart 1928, NJ 1928, blz. 829 e.v. (833). 
het structuurmodel komt de bevoegdheid tot benoeming van commissarissen aan dezelfde raad van commissarissen toe (art. 158). De coöptatiebevoegdheid wordt enigszins beïnvloed door het aan ava en or toegekende recht van bezwaar tegen een voorgenomen benoeming. Ook de mogelijkheid van rechterlijke toetsing van de afwijzing van het bezwaar vormt een zekere beperking van de bevoegdheid van de rvc. Het fundament waarop het systeem van de Structuurwet is gebouwd, is echter de juridische zelfstandigheid van de rvc bij de uitoefening van zijn bevoegdheden. Dit geldt in het bijzonder voor de bevoegdheid tot benoeming van commissarissen en bestuurders. De wet brengt dit tot uitdrukking in de artt. 158 lid 2 en 162 , waar zij bepaalt dat de bevoegdheid tot benoeming niet door enige bindende voordracht kan worden beperkt.

Aan de boven aangehaalde stelling van Meijers ligt kennelijk het ervaringsfeit ten grondslag dat wie eigen vermogen ter beschikking stelt, zeggenschap wenst te behouden over de aanwending van dat vermogen. In het geval van de aandeelhouders houdt deze zeggenschap doorgaans de bevoegdheid in om over de leidinggevende ambten te beschikken. Van deze bevoegdheid zijn aandeelhouders van structuurvennootschappen verstoken. Dit zou op zich niet bedenkelijk zijn wanneer het wezen van de vennootschap als kapitaalassociatie -en dus haar gerichtheid op het behalen van winst ten behoeve van de kapitaalverschaffers- onbetwist zou zijn. Nu echter door de "institutieleer" dit wezen en deze gerichtheid in twijfel zijn getrokken, is het niet verwonderlijk dat aandeelhouders niet gerustgesteld worden met met de constatering dat hun belangen mede "verdisconteerd" of "afgewogen" worden bij de bepaling van het vennootschappelijk belang, waarbij nog komt dat dit belang volgens de heersende leer zeker niet parallel behoeft te lopen met het belang van de aandeelhouders. In de praktijk wordt dan ook naar wegen gezocht om dit gebrek aan zeggenschap over de leidinggevende ambten op te vangen door middel van 'contractuele' regelingen. Deze komen er op neer dat commissarissen de benoemingsbevoegdheid uitoefenen onder zekere voorwaarden die door anderen -veelal kapitaalverschaffers- worden gesteld. Gezien de uitgangspunten van de Structuurwet rijst de vraag naar de geoorloofdheid van deze regelingen. Deze vraag wordt hier behandeld uitgaande van het geldend recht. ${ }^{44}$

44. Van den Hoek (1991), blz. 130, die tot nu toe de meest indringende apologie van deze regelingen heeft gemaakt, stelt: "Vanuit die in de praktijk bestaande behoefte heb ik het verschijnsel benaderd. Dat wil zeggen dat ik het positief benaderd heb. Ik vind het een taak voor juristen om de regels binnen de grenzen die niet mogen worden overschrijden zoveel mogelijk op te rekken. Ik vind niet alleen dat dat toegestaan is maar dat dit zelfs geboden is. Regels zijn een hulpmiddel." Voor zover de strekking van schrijvers betoog is dat aan de autonomie van de rechtsge-

(Wordt vervolgd...) 
Hetgeen hierna over de zgn. benoemingscontracten gezegd wordt, geldt mutatis mutandis voor elke andere overeenkomst die tot onderwerp heeft de uitoefening van bevoegdheden van commissarissen of van andere ambtsdragers. ${ }^{45}$

\section{a) Benoemingscontracten}

De problematiek van de benoemingscontracten kan worden geîllustreerd aan de hand van het arrest van de Hoge Raad van 19 maart $1975 .{ }^{46}$ I.c. had de rvc van HVA zich jegens grootaandeelhouder Socfin verbonden om de raad an te vullen met twee commissarissen die door Socfin zouden worden voorgedragen. Voorts kwamen partijen overeen dat de rvc geen commissaris zou benoemen ten aanzien van wie één der partijen gegronde bezwaren zou hebben. ${ }^{47}$ De Hoge Raad oordeelde dat een zodanige overeenkomst "op zichzelf niet in strijd [is] met een van de in het onderdeel genoemde artikelen van het Wetboek van Koophandel," waarbij het

44.(...vervolg)

noten niet meer beperkingen kunnen worden opgelegd dan die welke in de wet zijn vervat, moet daarmee worden ingestemd. Nochtans lijkt mij dat wanneer men met een dwingend systeem te doen heeft, de primaire taak van de jurist niet is het oprekken van grenzen (wat daaronder ook moge worden verstaan) maar het markeren ervan. Hoewel beide uitgangspunten tot dezelfde resultaten kunnen leiden, is niet onverschillig vanuit welk perspectief de wet wordt geïnterpreteerd.

45. Vgl. bijv. de hiervoor gemaakte opmerkingen omtrent overeenkomsten tot beslechting van geschillen, $\S 11$.

46. NJ 1976, 276, HVA-Westertoren III. Zie voor verdere informatie over een soortgelijk contract $L$. Timmerman, Fokker-Dasa, TVVS 1992, blz. 260 e.v.

47. De clausule in kwestie luidde als volgt: "Teneinde te bereiken dat de raad van commissarissen van de VHVAM naar behoren is samengesteld, verbindt het college van commissarissen van de VHVAM zich zijn college aan te vullen met twee leden, die zullen worden benoemd overeenkomstig het advies van SOCFIN. SOCFIN heeft te allen tijde recht op benoeming van een vierde van het totaal te benoemen aantal commissarissen met een minimum van twee overeenkomstig haar advies. Bij benoeming van nieuwe commissarissen, zullen dezen in kennis gesteld worden met de door het college van commissarissen aanvaarde verplichting als hierboven omschreven en dezen zullen zich bereid moeten verklaren aan de nakoming hiervan mede te werken.

Bij de benoeming van commissarissen zal ter bevordering van de goede samenwerking binnen het college over de voordracht van commissarissen voorafgaand overleg gepleegd worden over de te benoemen personen en zullen geen personen worden benoemd ten aanzien van wie een der contractspartijen gemotiveerd aantoont, dat tegen de voorgestelde personen voor haar gegronde bezwaren bestaan." 
onderdeel met name verwees naar de bepalingen van de Structuurwet. De aangehaalde woorden van de Hoge Raad zijn niet duidelijk. In de literatuur zijn deze woorden op verschillende wijze uitgelegd. Gesteld wordt dat de Hoge Raad mogelijk op het oog had het verschil tussen overeenkomsten die naar inhoud of strekking in strijd zijn met openbare orde en goede zeden en overeenkomsten die niet in strijd met de wet mogen worden aangegaan (art. 3:40 leden 1 en 2 BW). De Hoge Raad zou hebben bedoeld dat de wet het aangaan van benoemingscontracten niet verbiedt. Voor de andere nietigheidsgrond is echter geen verklaring. ${ }^{48}$ Aan dit onderscheid kan voorbij worden gegaan in zoverre de rechtsgevolgen gelijk zijn. De overeenkomst zou, indien de nietigheidsgrond aanwezig is, in beide gevallen nietig zijn.

Een andere verklaring is dat de overweging van de Hoge Raad "formeel" correct is omdat de overeenkomst de verdeling van bevoegdheden krachtens wet en statuten, welke verdeling voor een belangrijk deel van dwingende aard is, onaangetast laat. De overeenkomst zou slechts betrekking hebben op de wijze van uitoefening van de betrokken bevoegdheden, hetgeen overigens niet zonder meer wil zeggen dat de overeenkomst geldig is. ${ }^{49}$ Deze lezing lijkt mij correct en, zoals hierna zal blijken, ook in overeenstemming met eerdere jurisprudentie van de Hoge Raad. Alvorens echter op dit punt nader in te gaan moet de reikwijdte van de overeenkomst worden vastgesteld.

De hier besproken clausule van de overeenkomst luidt voor zover nu van belang: "Ten einde te bereiken (...) verbindt het college van commissarissen van de VHVAM zich..." Een andere clausule van dezelfde overeenkomst met betrekking tot de uitoefening van de emmissiebevoegdheid luidt echter: "De VHVAM en haar directie en commissarissen verplichten zich..." Terwijl derhalve in de eerste clausule gesproken wordt over het college van commissarissen, dit is: over de rvc als orgaan, wordt in de tweede clausule gesproken over "commissarissen"..$^{50}$ Anders dan de tekst van de eerste clausule stelt, moet worden aangenomen dat de rvc als orgaan geen partij bij de overeenkomst kan zijn. Partij zullen slechts de afzonderlijke commissarissen kunnen zijn. ${ }^{51}$ De rvc kan niet partij zijn bij de overeenkomst omdat hij geen rechtssubject is. Waar gesproken wordt over de

48. Vgl. Wachter in zijn noot onder het arrest; Boukema, TVVS 1975, blz. 178; Maeijer (1976), blz. 99.

49. Zo Wertheimer, TVVS 1975, blz. 294. Ook Van den Hoek (1991), blz. 88.

50. Verdedigd kan worden dat een zodanig verschil niet bestaat. Met de term "commissarissen" kan ook zijn bedoeld de commissarissen als college.

51. Zo ook Van der Grinten (1976), blz. 74; Van den Hoek (1991), blz. 91. Laatstgenoemde schrijver stelt echter op blz. 89 dat "elk orgaan (...) als partij" dient toe te treden. 
raad zal moeten worden verstaan: de natuurlijke personen die daar deel van uitmaken. Van den Hoek ${ }^{52}$ acht het mogelijk dat tot de overeenkomst alleen de voorzitter toetreedt "als vertegenwoordiger van het orgaan op basis van een intern genomen besluit" (mijn curs.). Verderop stelt schrijver echter: "De betreffende organen zijn geen rechtspersonen, waarachter de leden van het orgaan schuil gaan. Er is slechts sprake van een contract getekend door leden van een orgaan in hun kwaliteit." Dit laatste is juist. Het orgaan kan niet worden vertegenwoordigd omdat het überhaupt geen rechtssubject is. Indien men de leden van de raad tot de overeenkomst wil laten toetreden door middel van de voorzitter, zal moeten worden aangenomen dat het besluit van de raad waarbij tot toetreding wordt besloten een volmacht inhoudt van de instemmende commissarissen aan de voorzitter. Slechts deze commissarissen zullen partij zijn. Terecht acht Van den Hoek het dan ook verstandig dat alle commissarissen tot de overeenkomst toetreden voor zover men 'het orgaan' wil binden. Is er slechts een minderheid van de commissarissen partij, dan zal niet gesproken kunnen worden over een verplichting die op 'het orgaan' berust.

Vervolgens rijst de vraag naar de geoorloofdheid van een contractuele binding terzake van de commissariële bevoegdheden. De commissarissen die partij waren bij het hier aan de orde zijnde benoemingscontract verplichtten zich om zekere personen al of niet te benœemen. Een zodanige overeenkomst is in ieder geval niet een rechtshandeling waarbij de betrokken commissarissen over hun vermogen beschikken. Het onderwerp van de prestatie betreft niet bevoegdheden die aan de commissarissen persoonlijk toekomen maar bevoegdheden die verbonden zijn aan het ambt dat zij bekleden. Dit brengt met zich mee dat de commissarissen niet in privé over deze bevoegdheden zullen kunnen beschikken doch uitsluitend in hun kwaliteit van commissaris. In termen van de orgaan-theorie zou men kunnen stellen dat bij deze contractuele regelingen de rechtspersoon zelf (door middel van zijn organen) handelt en niet de natuurlijke personen die partij zijn bij de overeenkomst. Dit verklaart ook waarom als voorwaarde voor de geldigheid van de overeenkomst wordt gesteld dat zij de verdeling van bevoegdheden respecteert en in het belang van de vennootschap is aangegaan. ${ }^{53}$ Anderzijds volgt uit het feit dat de commissaris in deze hoedanigheid handelt, dat om de door de overeenkomst beoogde effecten tot stand te brengen de persoon die de overeenkomst aangaat commissaris dient te zijn. De kandidaat-commissaris die verklaart iemand niet te zullen benoemen is evenmin gebonden als welke andere persoon dan ook die de commissariële hoedanigheid ontbeert. Een andere opvatting is mogelijk.

52. (1991), blz. 90-91.

53. Zo Westbroek (1982), blz. 17-18; Van den Hoek (1991), blz. 92. 
Men zou kunnen stellen dat de overeenkomst is aangegaan onder de opschortende voorwaarde dat de kandidaat de hoedanigheid van commissaris verwerft. Tot op dat moment heeft de overeenkomst op dat punt geen rechtswerking.

Het feit dat commissarissen contractueel gebonden zijn, ontneemt hen niet de bevoegdheid om iets anders te besluiten dan datgene waartoe zij zich hadden verbonden. Hier dringt zich de vergelijking met de stemovereenkomsten tussen aandeelhouders op. Op dezelfde manier als aandeelhouders anders kunnen stemmen dan zij overeengekomen zijn zonder dat zulks de ongeldigheid van het besluit medebrengt, kunnen commissarissen een andere persoon benoemen dan die welke krachtens de overeenkomst zou 'moeten' worden benoemd. Evenwel bestaat op dit punt een belangrijk verschil tussen aandeelhouders en commissarissen. De aandeelhouder die anders stemt dan waartoe hij zich had verplicht pleegt in beginsel wanprestatie. Van een commissaris kan niet zonder meer hetzelfde worden gezegd. Immers, terwijl de aandeelhouder "in het hem verleende stemrecht niet een recht in het belang van anderen is toevertrouwd, doch een eigen recht is gegeven om zijn belang in de vennootschap te dienen"54, zijn de bevoegdheden van commissarissen ex lege functioneel bepaald. Omdat commissarissen steeds in het belang van de vennootschap moeten handelen, kunnen zij zich niet op voorhand binden met betrekking tot de uitoefening van bevoegdheden in toekomstige situaties. ${ }^{55}$ Indien de bij de overeenkomst betrokken commissarissen oordelen dat onder de gegeven omstandigheden het belang van de vennootschap eist dat een andere persoon wordt benoemd dan overeengekomen was, meen ik dat het niet zonder meer vaststaat dat zij wanprestatie plegen. Bij de ondertekening van de overeenkomst nemen commissarissen een inspanningsverplichting op zich en niet een resultaatsverplichting. $\mathrm{Zij}$ kunnen zich niet tot meer verbinden dan tot het bevorderen dat een bepaalde persoon zal worden benoemd. Wordt een andere persoon benoemd, dan heeft de wederpartij niet zonder meer een recht op nakoming van de overeenkomst (waartoe eerst nog vernietiging van het benoemingsbesluit nodig zou zijn) noch op schadevergoeding. Immers, eerst zou bewezen moeten zijn dat wanprestatie is gepleegd ten gevolge van het feit dat commissarissen zich niet de nodige inspanning hebben getroost. Dit bewijs zal moeilijk te leveren zijn omdat commissarissen een ruime mate van autonomie hebben in de beoordeling van hetgeen het vennootschappelijk belang eist en de wederpartij dit op grond van art. 140 behoort

54. HR 30 juni 1944, NJ 1944465 (Wennex). Zie hiervoor $\$ 1$,IV.

55. Overigens kan de aandeelhouder zijn autonomie ook niet geheel prijsgeven (vgl. noot 41 hiervoor). Wat hier wil worden benadrukt is dat, terwijl de aandeelhouder in beginsel vrij is om zich naar eigen inzicht te binden, de commissaris in de omgekeerde situatie verkeert. 


\section{BENOEMINGSCONTRACTEN}

te weten.

Tegen het zojuist gestelde zou men kunnen aanvoeren ${ }^{56}$ dat partijen juist beogen nader te bepalen wat het vennootschappelijk belang i.c. inhoudt. In het hier besproken geval zou dit aldus moeten worden geconcretiseerd dat naar het oordeel van partijen het vennootschappelijk belang vereist dat in de rvc van HVA steeds twee commissarissen uit de kring van de aandeelhouder Socfin zitting dienen te nemen. De vraag dient zich dan aan of een dergelijke 'overeenkomst' wel een overeenkomst is waaruit rechtens afdwingbare verplichtingen voortvloeien. In navolging van Van der Grinten ${ }^{57}$ zou ik menen dat soortgelijke afspraken niet meer zijn dan gentlemen agreements. Het zijn verklaringen van partijen omtrent hetgeen het vennootschappelijk belang volgens hen op het desbetreffende punt inhoudt. In hoeverre deze verklaringen bindend zijn is dan een andere vraag. Het zal van verschillende omstandigheden afhankelijk zijn of de rvc een gedragslijn kan volgen die contrair is aan de afgelegde verklaringen. Indien de rvc bijvoorbeeld met de enig aandeelhouder en met de cor afspreekt dat hij een bepaalde lijn zal volgen in zijn benoemingsbeleid, kan een besluit van de rvc waarin deze afspraken genegeerd worden er toe leiden dat de rvc niet "naar behoren" is samengesteld (art. 158 lid 6). Bij eventueel bezwaar zou de OK de voorgenomen benoeming kunnen tegenhouden. De rvc behoudt echter zijn autonomie om anders te besluiten dan oorspronkelijk afgesproken indien zulks naar zijn oordeel door het vennootschappelijk belang vereist wordt. ${ }^{58}$ Wat in elk geval in het systeem van de Structuurwet niet kan worden volgehouden is dat het vennootschappelijk belang eist dat bijvoorbeeld een vierde van de commissarissen afkomstig dient te zijn uit de kring van een $25 \%$ aandeelhouder. De zelfstandige uitoefening van de coöptatiebevoegdheid van de rvc verzet zich daartegen.

Over de commissariële bevoegdheden kan op twee manieren worden beschikt. In de eerste plaats kan worden overeengekomen dat de bevoegdheid niet door de rvc maar door de wederpartij zal worden uitgeoefend. Een dergelijke overeenkomst is van meet af aan nietig. De individuele commissarissen kunnen de bevoegdheid niet overdragen omdat niet zij competent zijn maar de raad als orgaan bevoegd is. Op zijn beurt kan de raad geen bevoegdheid overdragen die hem volgens de wet dwingend toekomt. Zo

56. Zo bijvoorbeeld Scholten (1976), blz. 140.

57. Interventie naar aanleiding van Van den Hoek's betoog (1991), blz. 130-131.

58. Vgl. Pres. Rb. Haarlem 19 februari 1988, KG 1988, 133. I.c. had de Raad yan Toezicht van een stichting met de or een profiel opgesteld waaraan de te benoemen bestuurder diende te voldoen. De benoemde persoon beantwoorde naar de mening van de or niet aan het geschetste profiel. De President acht de schending van de gedane toezeggingen i.c. onrechtmatig. 
bijvoorbeeld de bevoegdheid om de bezwaren van ava en or tegen een voorgenomen benoeming te beoordelen.

Een tweede mogelijkheid is dat aan de wederpartij enig recht wordt toegekend ten aanzien van de commissariële bevoegdheden. Deze blijven weliswaar bij de rvc, maar dit orgaan maakt zich op enigerlei wijze afhankelijk van de medewerking van de wederpartij. De HVA-overeenkomst geeft twee voorbeelden van een dergelijke regeling ten gunste van Socfin, te weten het recht om een aantal commissarissen voor te dragen en een vetorecht ten aanzien van voorgenomen benoemingen. Voor wat betreft het recht van voordracht was de rvc aangewezen, dat was althans de bedoeling, op het voorstel van Socfin terzake van de benoeming van een vierde van het totale aantal commissarissen. In het geval van het vetorecht kon de rvc geen benoeming verrichten waartegen Socfin gemotiveerd bezwaar had. Ik zou menen dat deze overeenkomsten nietig zijn voor zover zij er toe zouden leiden dat commissarissen in de uitoefening van hun bevoegdheden gebonden zouden zijn aan het oordeel van derden. De nietigheid van de overeenkomst berust op het feit dat alsdan zeggenschap met betrekking tot het commissariële toezicht zou worden toegekend aan personen die de commissariële verantwoordelijkheid niet dragen. Of een dergelijke situatie zich voordoet, is op voorhand niet te zeggen. In de praktijk kunnen zich vele varianten voordoen. Aan het ene uiteinde zouden kunnen worden geplaatst de min of meer vrijblijvende gentlemen-agreements over omstandigheden en belangen waarmee commissarissen bij hun taakvervulling rekening dienen te houden. Aan het andere uiteinde zouden zich bevinden gedetailleerde afspraken met dwangsom over inwinning van advies en dergelijke. Hoe dichter de overeenkomst bij dit tweede uiteinde is, des te groter de kans is dat zij als ongeoorloofd zal moeten worden beschouwd omdat daaruit de intentie blijkt om de commissaris te dwingen zijn bevoegdheid uit te oefenen op een door een derde bepaalde manier. Deze overeenkomsten kunnen feitelijk tot een overdracht van de bevoegdheid in kwestie leiden, welke overdracht hiervoor nietig werd geacht. Men denke aan het geval dat commissarissen zich zouden verbinden om bezwaren van de ava tegen bepaalde kandidaten niet in overweging te nemen of bestuursbesluiten, genoemd in art. 164, alleen onder in de overeenkomst aangegeven omstandigheden af te keuren. In deze gevallen blijt de bevoegdhedenverdeling formeel wellicht onaangetast maar de facto wordt zij illusoir gemaakt. Een overeenkomst die tot een dergelijk resultaat zou leiden zou rechtens ongeoorloofd zijn.

Uit het voorgaande moet niet worden afgeleid dat elke handeling waarbij commissarissen over de wijze van uitoefening van hun bevoegdheden beschikken als ongeoorloofd moet worden beschouwd. In navolging van de 
Hoge $\operatorname{Raad}^{59}$ moet worden aangenomen dat niet elke dispositie verboden is. Toelaatbaar zijn in de eerste plaats regelingen die de rvc door middel van besluit of reglement treft voor de uitoefening van zijn bevoegdheden. In dit geval vindt geen overdracht van bevoegdheid aan een derde plaats en is de rvc zelfstandig in de uitoefening van de betrokken bevoegdheid. Te dien aanzien bestaat een ruime regelingsbevoegdheid zolang de taakuitoefening van de individuele leden niet onmogelijk wordt gemaakt of onevenredige zeggenschap aan een of meer leden wordt toegekend. Zo kunnen bij reglement of besluit de wijze van uitoefening van het informatierecht worden geregeld, quorumvereisten voor het nemen van besluiten worden gesteld, een profiel van te benoemen bestuurders of commissarissen worden vastgesteld, etc.

In de tweede plaats kunnen commissarissen zich jegens derden verbinden ten aanzien van de uitoefening van hun bevoegdheden wanneer zulks in bepaalde omstandigheden in het belang van de vennootschap geboden is. De overeenkomst kan weliswaar één of meer toekomstige aangelegenheden betreffen, maar de rvc zal per geval ${ }^{60}$ autonoom moeten beoordelen in hoeverre het vennootschappelijk belang eist dat commissarissen conform de in de overeenkomst genoemde wijze handelen. Deze vrijheid van beoordeling dient in de overeenkomst te worden gewaarborgd. Een schoolvoorbeeld van een zodanige overeenkomst geeft bovengenoemd arrest van de Hoge Raad. ${ }^{61}$ Het ging i.c. om een overeenkomst waarbij commissarissen zich verbonden om mee te werken aan een bepaalde aandelenoverdracht en tot het zich terugtrekken uit de rvc met het doel "om moeilijkheden in den boezem der N.V. gerezen tusschen commissarissen enerzijds en den directeur anderzijds ... op te lossen." Het contract had i.c. tot doel de besluitvorming in de vennootschap überhaupt mogelijk te maken. Een dergelijke overeenkomst is geoorloofd, en het aftreden van commissarissen zou bijgevolg in rechte kunnen worden afgedwongen, omdat zonder besluitvorming het doel van de vennootschap niet bereikbaar is en de bevoegdheden van commissarissen zinloos zijn.

\section{b) Benoemingsprocedure}

De bijzondere positie van de rvc in de Structuurwet komt mede tot uitdrukking in de procedure tot benoeming van commissarissen. In essentie komt de procedure op het volgende neer. De rvc benoemt zijn eigen leden. De

59. HR 30 maart 1928, NJ 1928, blz. 829 e.v.

60. Vgl. ook Van den Hoek (1991), blz. 88.

61. HR 30 maart 1928, NJ 1928, blz. 829. 
benoemingsbevoegdheid kan niet worden beperkt door enige voordracht (art. 158 lid 2). Hieronder zal moeten worden verstaan dat zowel de rvc als de individuele commissarissen, statutair nog contractueel, zeggenschap van derden hebben te dulden ten aanzien van de benoeming. Voor zover de benoemingsbevoegdheid wordt beperkt, vindt de beperking haar fundament in de wet (art. 158 lid 12, inhoudende de bevoegdheid van de overheid tot benoeming van een of meer commissarissen) of in een handeling van het openbaar gezag welke ook op een wettelijke grondslag berust (bijvoorbeeld de ontheffing door de minister van Justitie van één of meer wettelijke voorschriften op grond van art. 156). De rvc is echter niet geheel vrij terzake van de benoeming. Ten eerste dient de rvc de algemene vergadering, het bestuur en de ondernemingsraad in de gelegenheid te stellen kandidaten voor te dragen. Inherent aan het advies is dat dit niet bindend is, zodat de raad een andere persoon kan benoemen dan de persoon die was voorgedragen. Een tweede beperking is dat zowel de algemene vergadering als de ondernemingsraad bezwaar kunnen maken tegen de persoon die de rvc voornemens is te benoemen. Ava en or kunnen dit bezwaar maken ongeacht of zij van de adviesbevoegdheid gebruik hebben gemaakt. Indien bezwaar is gemaakt, is de rvc alleen bevoegd om de kandidaat te benoemen wanneer de OK, op voorstel van de rvc, die in deze door één van zijn leden wordt vertegenwoordigd, het bezwaar ongegrond verklaart. Op haar beurt kan de OK het bezwaar slechts ongegrond verklaren krachtens drie in de wet genoemde redenen. ${ }^{62}$

De benoemingsprocedure zal hierna niet in detail worden behandeld. ${ }^{63}$ Ik zou slechts aandacht willen besteden aan enkele vragen waartoe de wettelijke regeling aanleiding geeft.

Verschil van mening bestaat over de vraag of de statuten nadere bepalingen omtrent het aanbevelings- en bezwaarrecht van de ava kunnen bevatten ${ }^{64}$ Hierbij kan worden gedacht aan de eis van goedkeuring van het besluit door een ander vennootschapsorgaan, aan versterkte meerderheid van stemmen en aan quorumeisen. Algemeen wordt aangenomen dat het onderwerpen van genoemde ava-besluiten aan de goedkeuring van een ander orgaan, waarbij vooral op de prioriteit wordt gedoeld, ontoelaatbaar is. ${ }^{65}$ Minder consensus bestaat op het punt van de versterkte meerderheid

62. Zie over dit punt nader $\S 15, I V$.

63. Zie over het onderwerp met name H.J.M.N. Honée, De benoeming van commissarissen bij grote vennootschappen, Deventer 1979, alwaar tevens de toepassing van de regeling in de praktijk wordt besproken.

64. Ook met betrekking tot andere besluiten van de ava zouden nadere regelingen denkbaar zijn. Vgl. Lubbers (1973), blz. 59.

65. Zie voor allen Timmerman, Rechtspersonen, art. 158, aant. 9. 
van stemmen. De meeste auteurs zijn van mening dat de eis niet toelaatbaar is, doch ook het tegenovergestelde standpunt wordt verdedigd. ${ }^{66}$ Ten aanzien van de quorumeis is -voor zover ik kan nagaan- slechts Van der Grinten van oordeel dat de eis niet toelaatbaar is ${ }^{67}$ In de gevallen waarin deze regelingen toelaatbaar worden geacht, wordt ter motivering gewezen op de principiële vrijheid van de ava terzake van haar eigen besluitvorming (art. 120) ${ }^{68}$, dan wel op de positieve effecten van de dergelijke regelingen. ${ }^{69}$ Het komt mij voor dat de aangedragen argumentatie niet doeltreffend is en dat in navolging van Van der Grinten aangenomen moet worden dat bedoelde maatregelen niet geoorloofd zijn.

Het moge zo zijn dat het invoeren van een zekere oligarchie terzake van de besluitvorming positieve effecten voor de vennootschap kan hebben. Dit enkel feit zegt echter niet of een zodanige oligarchie met de rechtsorde verenigbaar is. Het is overigens de vraag of de oligarchie steeds positieve effecten heeft. De maatregel zou slechts dan geoorloofd zijn wanneer bedoelde effecten vaststaan. Reeds omwille van de rechtszekerheid is deze argumentatie dan ook niet te onderschrijven. Wat betreft de verwijzing naar de principiële vrijheid van de ava ex art. 120 geldt het volgende. Art. 120 regelt de besluitvorming door de ava. Voor zover hier van belang, komen deze regels er op neer dat de algemene vergadering vrij is om af te wijken van het beginsel dat het besluit tot stand komt indien de volstrekte meerderheid van uitgebrachte stemmen voor het besluit is. Echter, het feit dat deze vrijheid bestaat betekent niet dat zij ook dient te gelden ten aanzien van de hier besproken besluiten. Lubbers rechtvaardigt de toepasselijkheid van art. 44d WvK (nu art. 120) op het aanbevelings- en bezwaarrecht van de ava met een beroep op "een uniforme wetsinterpretatie" ${ }^{70}$, maar meent anderzijds dat het artikel niet toepasbaar is op andere onderdelen van de Structuurwet, zoals de intrekking van de commissie van aandeelhouders of het ontslag van de voorzitter van deze commissie. ${ }^{71}$ De geoorloofdheid van "een uniforme wetsinterpretatie" dient mijns inziens ook terzake van het aanbevelings- en bezwaarrecht te worden bewezen. Naar mijn mening bestaat ten aanzien van deze rechten niet de vereiste "uniformiteit" opdat

66. Contra: Maeijer (1973), blz. 20; Timmerman, Rechtspersonen, art. 158, aant. 9; Van Schilfgaarde (1992), nr. 142; Handboek, nr. 286. Pro: Uniken Venema (1970), blz. 133; Lubbers (1973), blz. 59.

67. Hanboek, nr. 286.

68. Vgl. Lubbers (1973), blz. 57.

69. Aldus Uniken Venema (1970), blz. 133; Maeijer (1973), blz. 20: "het stellen van een quorum-eis (...) lijkt mij hier functioneel ten aanzien van het belang van de grote vennootschap zélf, en daarom geoorloofd."

70. (1973), blz. 59.

71. (1973), blz. 60. 
afwijking van het beginsel van volstrekte meerderheid der uitgebrachte stemmen geoorloofd is. Immers, op dezelfde manier als het beginsel niet geldt voor besluiten die krachtens wet of statuten met meer dan volstrekte meerderheid van stemmen dienen te worden genomen, moet het beginsel wél gelden voor besluiten waarvoor géén hogere eisen mogen worden gesteld dan bedoelde volstrekte meerderheid. De vraag echter of deze hogere eisen gesteld mogen worden is niet een vraag die door art. 120 wordt beantwoord omdat zij niet de besluitvorming in de zin van dit artikel betreft. Het is een vraag omtrent het besluit in kwestie. Dit wil zeggen dat i.c. uit art. 158 of uit het wettelijk systeem zou moeten blijken dat voor het aanbevelings- of bezwaarrecht versterkte quorum- of meerderheidseisen kunnen worden gesteld. Nu meen ik dat de aard van het aanbevelings- en bezwaarrecht zich tegen het stellen van dergelijke eisen verzet. Het voordragen van een kandidaat door de ava of het bezwaar maken tegen de door de rvc voorgedragen persoon zijn geen bevoegdheden die zich lenen voor een oligargische regeling. Voor zover deze regelingen bedoeld zijn om te voorkomen dat een voor de vennootschap ingrijpende maatregel wordt genomen, zonder dat een representatieve meerderheid onder de aandeelhouders bestaat, missen oligarchische regelingen hun betekenis in de hier besproken gevallen. Wat het aanbevelingsrecht betreft is reeds gezegd dat de rvc niet gebonden is aan de aanbeveling van de ava. Het enige gevolg van de aanbeveling is dat de rvc gehouden is zich te buigen over de geschiktheid van de voorgedragen persoon voor de bestaande vacature. Voor het bezwaarrecht geldt slechts in zoverre anders, dat het maken van bezwaar de benoemingsbevoegdheid van de rvc 'blokkeert'. De rvc kan niet de voorgedragen persoon benoemen indien de ava bezwaar maakt. Echter, omdat de bezwaargronden beperkt zijn in aantal en een objectief karakter hebben, in die zin dat zij aan rechterlijke toetsing kunnen worden onderworpen, heeft een kwantitatieve maatregel als waarvan hier sprake is mijns inziens geen zin. Het al of niet gegrond zijn van de bezwaren is een omstandigheid die op zich los staat van het aantal stemmen dat het bezwaar steunt. Dit is met name het geval voor de eerste bezwaargrond, namelijk het niet naleven van de benoemingsprocedure. Ten aanzien van de tweede en derde bezwaargronden, namelijk dat de kandidaat ongeschikt is en dat de rve niet naar behoren zal zijn samengesteld, is het aantal stemmen slechts in zoverre relevant dat de OK deze omstandigheid kan betrekken in haar oordeelsvorming, in dier voege dat hoe hoger het aantal tegenstemmers, des te groter de kans dat de OK het bezwaar gegrond acht. ${ }^{n}$ Doorslaggevend is het aantal stemmen echter niet.

72. In gelijke zin, met betrekking tot beoordeling van het bezwaar door de SER, Maeijer (1973), blz. 20. 


\section{BENOEMINGSPROCEDURE}

Gewezen wordt voorts op het gevaar van misbruik van het aanbevelings- en bezwaarrecht indien een kleine meerderheid van de ter vergadering aanwezige aandeelhouders voldoende zou zijn om de besluiten te nemen. Voor zover misbruik van deze bevoegdheid te duchten valt, dient de oplossing te worden gevonden in een actie op grond van art. 8. en niet in het opleggen van een beperking aan de bevoegdheidssfeer van de ava die geen steun vindt in de Structuurwet.

Het aanbevelings- en bezwaarrecht is een bevoegdheid van de ava en de or. Terzake van de aanbeveling is ook het bestuur bevoegd. Deze rechten zullen dan ook moeten worden uitgeoefend door de leden van de betrokken organen of door hun vertegenwoordigers. Onjuist acht ik dan ook het standpunt $^{73}$ dat de bevoegdheid tot het doen van een voorstel aan een ieder toekomt die het vergaderrecht heeft. Het is niet in te zien waarom het vergaderrecht de bevoegdheid zou moeten inhouden om voorstellen te doen met betrekking tot onderwerpen die volgens de wet tot de uitsluitende bevoegdheid van met name genoemde organen behoren. Overigens is de praktische betekenis van deze kwestie gering. Wanneer ter algemene vergadering besloten zou worden een stemming te houden over een aanbeveling die niet door een aandeelhouder is gedaan, zou de stemming aldus moeten worden verstaan dat de aandeelhouders het voorstel tot aanbeveling aanvaarden.

\section{c) De commissie van aandeelhouders}

Enkele bevoegdheden van de ava met betrekking tot benoeming en ontslag van bestuurders en commissarissen kunnen bij structuurvennootschappen op grond van art. 158 lid 11 aan een zgn. commissie van aandeelhouders worden overgedragen. De introductie van deze commissie beoogde de uitoefening van deze bevoegdheden te vergemakkelijken. Voor de uitoefening van deze bevoegdheden zou het niet nodig zijn de algemene vergadering bijeen te roepen. ${ }^{74}$ De wet regelt het onderwerp niet uitputtend.

Allereerst dient de rechtspositie van de commissie te worden bepaald. De commissie kan als een vennootschapsorgaan worden beschouwd. Zij is voorts een aan de ava ondergeschikt orgaan omdat haar bevoegdheden door de algemene vergadering zijn overgedragen en de overdracht te allen tijde ongedaan kan worden gemaakt. De commissie van aandeelhouders is in het

73. In deze zin echter Lubbers (1973), blz. 54 en Handboek, nr. 286.

74. De antecedenten van de regeling worden uitvoerig behandeld door Honée (1979), blz. 111 e.v. 
systeem van de wet niet een 'mini-ava'." De overdracht van bevoegdheden berust op een besluit van de algemene vergadering. Het besluit waarbij de bevoegdheden worden overgedragen en het orgaan wordt ingesteld kan te allen tijde worden genomen. De statuten behoeven niet te voorzien in de mogelijkheid tot instelling van de commissie. De bevoegdheid tot instelling heeft de ava ex lege.

Zoals gezegd, wordt de rechtspositie van de commissie bepaald door het feit dat haar bevoegdheden op een overdracht door de algemene vergadering berusten. Deze overdracht is slechts mogelijk omdat de wet dit uitdrukkelijk toelaat. De algemene vergadering kan immers de bevoegdheden die zij in vergadering dient uit te oefenen, en waarvoor o.a. zekere bijeenroepingsvereisten gelden, in beginsel niet aan een derde overdragen. Overdracht is slechts mogelijk onder bepaalde voorwaarden. De overdracht kan bijvoorbeeld noch voor een langere periode dan twee jaar plaatsvinden, noch andere bevoegdheden betreffen dan in de wet uitdrukkelijk toegestaan. De door de wet geopende mogelijkheid tot overdracht brengt anderzijds met zich mee dat aan de overdracht geen andere beperkingen kunnen worden opgelegd dan die welke in de wet zijn opgenomen. Verdedigd wordt wel dat slechts aandeelhouders lid van de commissie kunnen zijn, zulks omdat de wet spreekt over een commissie van aandeelhouders. ${ }^{76}$ Het taalkundige argument biedt mijns inziens onvoldoende steun om een dergelijke kwaliteitseis te stellen. ${ }^{77}$ De wet stelt in ieder geval niet een dergelijke eis. Reeds eerder is gesteld dat de rechtspositie van de commissie bepaald wordt door het besluit van de algemene vergadering. Het lidmaatschap van de rechtspersoon is in deze geen vereiste. De commissie is overigens geen commissie van aandeelhouders doch van de aandeelhouldersvergadering. Ook een minimum aantal leden wordt niet door de wet voorgeschreven. ${ }^{78}$ Het feit dat de wet spreekt over de leden van de commissie is wederom onvoldoende grond om de pluraliteitseis te stellen. De term 'commissie' is een terminus technicus. Evenals een algemene vergadering uit eén persoon kan bestaan, is een eenpersoonscommissie bestaanbaar. Overdracht van én of meer van de in de wet genoemde bevoegdheden aan én persoon moet dan ook toelaatbaar worden geacht. De aangewezen persoon is dan de commissie van aandeelhouders.

75. Anders kennelijk Van den Ingh, WPNR 6068 (1992), blz. 805-806, waar hij -mede met een beroep op Pitlo-Lowensteyn, blz. 309- de commissie van aandeelhouders vergelijkt met de ledenraad van het verenigingsrecht (art. 39). Echter, reeds uit de tekst van artikel 39 blijkt dat de ledenraad, anders dan de commissie van aandeelhouders, in werkelijkheid de algemene vergadering is.

76. Van Schilfgaarde (1992), $\mathrm{nr}, 145$.

77. Evenzo Handboek, nr. 289; Sanders/Westbroek (1991), blz. 205; \& 15 Dep. Richtl.

78. Anders Handboek, nr. 289; Lubbers (1973), blz. 61. 
$\mathrm{Nu}$ de wet overdracht van verschillende bevoegdheden toestaat (artt. 158 lid 11, 159 lid 4, 161 lid 2, 162) doet zich de vraag voor of deze bevoegdheden afzonderlijk kunnen worden overgedragen. Algemeen wordt aangenomen dat dit wel mogelijk is, doch dat een zekere eenheid bestaat tussen enkele groepen van bevoegdheden die dus niet vatbaar zijn voor afzonderlijke overdracht, bijvoorbeeld de bevoegdheden ex art. $158 .^{79}$ Erkend moet worden dat in de wettekst de bevoegdheden ex art. 158 als eenheid lijken te worden gezien. Gesproken wordt immers over "de bevoegdheden en verplichtingen". Voorts stelt artikel 158 dat de rvc aan de commissie kennis geeft van de naam van degene die hij voornemens is tot commissaris te benoemen. Hieruit zou kunnen worden geconcludeerd dat terzake van de benoeming, de rvc zich slechts met de commissie van aandeelhouders dient te verstaan en niet tevens met de ava. Uitgaande van de door de wet geopende mogelijkheid tot overdracht van de verschillende bevoegdheden, is het echter niet in te zien waarom de ava niet bevoegd zou kunnen zijn om het aanbevelingsrecht los van het bezwaarrecht over te dragen. Naar mijn mening verzet de wet zich niet tegen afzonderlijke overdracht. De wet verbiedt mijns inziens ook niet dat de mededelingen die de rvc aan de commissie doet, op de gebruikelijke wijze tevens aan de ava worden gedaan.

Voor zover de algemene vergadering nadere eisen aan de overdracht wenst te stellen, dient zij zulks te doen krachtens statuten, reglement of besluit. Een van deze voorwaarden kan mijns inziens zijn de toewijzing van een bepaald aantal stemmen aan ieder lid van de commissie. Timmerman stelt echter: "Ieder lid van de aandeelhouderscommissie heeft een even zware stem; het is ons inziens onverenigbaar met de aan de structuurregeling ten grondslag liggende filosofie, dat het aantal stemmen van ieder commissielid afhankelijk zou zijn van het aantal door hem gehouden aandelen. " $\$ 20 \mathrm{k}$ zou echter menen dat de "filosofie" van de structuurregeling het hoofdbeginsel van het vennootschapsrecht neergelegd in art. 118 onaangetast laat. Zolang wettelijk of statutair niet anders is bepaald, komt aan iedere aandeelhouder, ook bij structuurvennootschappen, een zeggenschap toe die proportioneel is aan het door hem ingebrachte kapitaal. Op dezelfde manier als de besluitvorming omtrent de onderwerpen bedoeld in art. 158 ter algemene vergadering bepaald wordt door de kapitaalparticipatie van aandeelhouders, kan de door dezelfde aandeelhouders ingestelde commissie eenzelfde proportionaliteit aanhouden. Indien de vergadering uit twee aandeelhouders bestaat, één met $67 \%$ van het kapitaal en de andere met

79. In deze zin Handboek, nr. 289; Lubbers (1973), blz. 62; Van Schilfgaarde (1992), nr. 145, acht overdracht van "een aantal" bevoegdheden toelaatbaar.

80. Rechtspersonen, art. 158, aant. 11. Zo ook Slagter (1990), blz. 305. 
$33 \%$, is het niet in te zien waarom bij instelling van een commissie waarin iedere aandeelhouder een vertegenwoordiger benoemt, an beide commissieleden een even zwaar stemrecht zou moeten toekomen.

Onder de voorwaarden vastgesteld door de ava bij het instellingsbesluit is de commissie ook bevoegd regels te geven omtrent haar functioneren.

Instelling van een commissie van aandeelhouders kan risico's met zich mee brengen voor minderheidsaandeelhouders. Indien de meerderheid zou beslissen over instelling en bemanning van de commissie zou dit feitelijk kunnen betekenen dat de minderheid verstoken blijft van zeggenschap met betrekking tot de onderwerpen die tot de bevoegdheidssfeer van de commissie behoren. Terecht wordt dan ook in de literatuur gesteld dat ter bescherming van minderheidsaandeelhouders het wenselijk is het besluit tot instelling van de commissie, tot benoeming van haar leden, etc. statutair te onderwerpen aan versterkte meerderheids en/of quorumeisen. ${ }^{81}$ De wet eist zulks echter niet. Besluiten tot instelling van de commissie of tot benoeming van haar leden, als ook besluiten van de commissie die onrechtmatig zijn jegens de minderheid kunnen worden vernietigd (art. 15 lid 1 $\operatorname{sub} b)$.

\section{Schorsing van commissarissen}

In het systeem van de Structuurwet past dat de bevoegdheid tot schorsing van commissarissen aan de rvc toekomt (art. 161 lid 3). Met de onafhankelijkheid van de rvc zou zich slecht verdragen dat een ander orgaan op dit punt zeggenschap zou hebben over de rechtspositie van de commissarissen. Met de onafhankelijkheid van de afzonderlijke commissaris zou voorts moeilijk te rijmen zijn dat de rvc commissarissen ad nutum zou kunnen schorsen. Om deze reden werd in het voorstel van de Commissie Ver$\mathrm{dam}^{82}$, en in het daarop voortbouwend SER-advies over de herziening van het ondernemingsrecht ${ }^{83}$, de schorsingsbevoegdheid afhankelijk gemaakt van de aanwezigheid van een gewichtige reden. Schorsing en ontslag waren in bedoelde voorstellen slechts mogelijk op grond van de daarin genoemde

81. Zie Timmerman, Rechtspersonen, art. 158, aant. 11 en de door hem aangehaalde schrijvers.

82. Vgl. art. $50 \mathrm{~g}$ van diens voorontwerp van wet: "tussentijds kunnen zij] [commissarissen] slechts worden geschorst en ontlagen wegens verwaarlozing van hun taak, wegens andere gewichtige redenen of wegens ingrijpende wijziging van de omstandigheden, ten gevolge waarvan handhaving als commissaris redelijkerwijs niet kan worden verlangd."

83. Advies d.d. 19 september 1969, Uitgave van de SER, nr, 14, blz. 24. 
redenen, welke overeenkomen met de huidige ontslaggronden. Beide maatregelen dienden voorts door de OK te worden genomen. De Structuurwet brak met deze voorstellen in zoverre, dat de bevoegdheid tot schorsing aan de rvc werd toegekend en niet aan de OK. Voor deze wijziging werden argumenten van praktische aard aangevoerd. Ook werd gewezen op de beperkte duur van de schorsing en op het feit dat het rechterlijke oordeel toch zou worden betrokken indien vóór het verval van de schorsing een verzoek tot ontslag zou worden ingediend. ${ }^{84}$

De wetgever heeft een zeker onderscheid aangebracht tussen schorsing en ontslag. De vraag rijst of dit verschil in de wettelijke regeling doorwerkt in de gronden waarop beide maatregelen kunnen worden toegepast. Met andere woorden, of schorsing in tegenstelling tot ontslag ook mogelijk is wanneer geen van de drie wettelijke ontslaggronden (art. 161 lid 2) zich voordoet. Naar mijn mening dient deze vraag ontkennend te worden beantwoord. In het systeem van de Structuurwet bestaat een zekere eenheid tussen de bevoegdheid tot schorsing en tot ontslag wanneer de rve het bevoegde orgaan is. Beide maatregelen hebben voorts een ander karakter dan in het gewone model..$^{85}$ Voor wat betreft de bevoegdheid tot ontslag blijkt dit uit de wettelijke opsomming van gronden waarop het ontslag dient te zijn gebaseerd. Ten aanzien van de schorsingsbevoegdheid is dit af te leiden uit de zojuist aangehaalde wordingsgeschiedenis van art. 161. Het lijkt mij dat in het structuurmodel de schorsingsbevoegdheid van de rvc geen discretionaire bevoegdheid is zoals de schorsingsbevoegdheid van de ava bij gewone vennootschappen in de hiervoor bedoelde zin. De bevoegdheden van de rvc zijn functioneel van aard. Ik zou menen dat de bevoegdheid tot schorsing dient te worden uitgeoefend op grond van éen van de drie in art. 161 lid 2 genoemde omstandigheden. Anderzijds geldt dit mijns inziens niet voor de schorsingsbevoegdheid van de overheid wanneer zij krachtens art. 161 lid 4 bevoegd is de door haar benoemde commissaris te schorsen en te ontslaan. De bevoegdheid van de overheid is evenals die van de ava in het gewone model niet functioneel bepaald.

Het praktisch belang van deze kwestie is overigens in zoverre gering dat de wettelijke gronden dermate open zijn dat de rvc een ruime beoordelingsvrijheid heeft bij de uitoefening van de bevoegdheid.

Schorsing kan tot slot als voorziening in het kader van een enquêteprocedure door de OK worden opgelegd (art. 356 sub b).

84. Vgl. Maeijer, Wetsgeschiedenis, IXf. Art. 52k (III) - 2 .

85. Vgl. $\$ 13$,II. 


\section{Ontslag van commissarissen}

Ontslag bewerkstelligt het einde van de vennootschapsrechtelijke relatie tussen commissaris en vennootschap. Nu deze relatie vennootschapsrechtelijk van aard is, gelden de regels van het gemene recht niet. ${ }^{86}$ Wettelijk eindigt de relatie uiterlijk vier jaar na de benoeming of op een eerdere datum indien de commissaris de leeftijd van 72 jaar bereikt (art. 142 lid 4). Mogelijk is ook dat het ontslag intreedt op de dag van de eerstvolgende algemene vergadering na afloop van genoemde termijn van vier jaren, indien zulks statutair is bepaald (art. 161 lid 1). Mijns inziens moet de wet aldus worden verstaan dat verlenging van bedoelde termijn krachtens besluit niet mogelijk is ${ }^{87}$ De statuten kunnen de duur van de aanstelling bepalen op een kortere periode dan vier jaren. Deze mogelijkheid van statutaire limitering wordt echter in de literatuur bestreden omdat in het stelsel van de wet niet zou passen dat de ava de duur van de aanstelling bepaalt. ${ }^{88}$ Mij dunkt echter dat een statutaire vaststelling van de zittingsduur van commissarissen geen afbreuk doet aan de onafhankelijkheid van de raad. ${ }^{89}$ Wat niet in de macht van de ava ligt, is de statutaire limitering te laten gelden voor commissarissen die voor het invoeren van de limitering werden benoemd. Dit zou immers neerkomen op ontslag van de commissaris door de algemene vergadering. De verhouding tussen commissaris en vennootschap wordt te dien aanzien echter geregeerd door het aanstellingsbesluit en door de statuten zoals deze golden ten tijde van de aanstelling. Een latere wijziging heeft geen werking jegens de commissaris. ${ }^{90}$

De drie wettelijke ontslaggronden zijn: verwaarlozing van de commissariële taak, andere gewichtige redenen en ingrijpende wijziging van de omstandigheden op grond waarvan handhaving van de verhouding niet van de ven-

86. Anders dan in het Handboek, nr. 295, is het mijns inziens niet zo dat de regels van Boek 2 aan het gemene recht "derogeren".

87. Evenzo Handboek, nr. 295.

88. Aldus Timmerman, Rechtspersonen, art. 161, aant. 2. Wel geoorloofd wordt geacht dat de statuten aan de raad de bevoegdheid geven om commissarissen voor een kortere periode dan vier jaren te benoemen. Deze statutaire bepaling heeft echter geen zin omdat, zoals genoemd schrijver zelf (t.a.p.) erkent, de bevoegdheid tot benoeming voor een kortere periode aan de raad ex lege toekomt.

89. Zo ook Dep. Richtl. \$14 en Handboek, nr. 295.

90. Dit is kennelijk ook de strekking van $\$ 14$ Dep. Richtl. waar bepaald wordt dat wijziging van het rooster van aftreden er niet toe kan leiden dat een commissaris tegen zijn wil zou dienen af treden. 
nootschap kan worden verlangd. ${ }^{91}$

De ontslaggronden vormen een open norm. Jurisprudentie over het onderwerp bestaat niet. ${ }^{92}$ Op voorhand is niet te zeggen welke omstandigheden het ontslag rechtvaardigen.

Verwaarlozing van de taak betekent dat de commissaris in strijd handelt met art. $8 .{ }^{93}$ Echter, niet elk onbehoorlijk handelen van de commissaris zal als verwaarlozing van zijn taak moeten worden beschouwd. Uit de overige ontslaggronden volgt mijns inziens dat de omstandigheden die het ontslag dragen een ernstig karakter dienen te hebben. Opdat deze ontslaggrond zich voordoet is het noodzakelijk dat de fouten die de commissaris worden verweten binnen het kader van zijn taakvervulling plaatsvinden.

Anders is de situatie bij de ontslaggrond "andere gewichtige redenen". Hier kunnen persoonlijke omstandigheden van de commissaris die op zich los staan van zijn taakvervulling een rol spelen. Een commissaris wiens privé-leven het aanzien van de vennootschap schaadt kan mijns inziens worden ontslagen. Wel zullen deze omstandigheden ernstig van aard moeten zijn en zullen zij enig verband dienen te houden met het functioneren van de commissaris in deze hoedanigheid.

Wat betreft de "ingrijpende wijzigingen der omstandigheden" gaat het mijns inziens erom dat het voordeel van het in stand houden van de relatie tussen commissaris en vennootschap niet opweegt tegen de schade die genoemde instandhouding voor de vennootschap medebrengt. Het rapport Verdam ${ }^{94}$ en de MvT $^{95}$ noemen als voorbeeld van zo'n omstandigheid het geval van fusie.

De ontslagbevoegdheid berust niet bij de OK wanneer het gaat om een overheidscommissaris benoemd op grond van art. 158 lid 12. Ontslag wordt door de benoemende instantie verleend. Op dit punt geldt mijns inziens hetzelfde als ten opzichte van de schorsingsbevoegdheid. De bevoegde instantie is niet gebonden aan de ontslaggronden van art. 161 lid 2. De haar toekomende bevoegdheid, welke niet afdoet aan de mogelijkheid

91. Over de mogelijkheid om de wettelijke ontslaggronden uit te breiden vgl. de opmerkingen die gemaakt worden terzeke van contractuele uitbreiding van de bezwaargronden, hierna $\$ 15$,IV.

92. Voor zover mij bekend heeft de OK tot nu toe slechts éen keer art. 161 toegepast. Het betrof het voltallige college van commissarissen van Westhaven N.V.. Zie OK 19 december 1985, TVVS 1986, biz. 54, nt. Rood. De beschikking is om hier niet terzake doende gronden door de Hoge Raad vernietigd, HR 24 december 1986, NJ 1987,903 , nt. Ma, en TVVS 1987, blz. 73 e.v. nt. Slagter.

93. Hierover nader $\$ 17$, I.

94. Commissie Verdam, blz. 124.

95. Macijer, Wetsgeschiedenis, IXf - Art. 52k (III) - 2. 
tot ontslag door de OK op grond van art. 161 lid 1, is niet functioneel bepaald. Om de door haar benoemde commissaris te ontslaan behoeft de overheid niet te wachten totdat één van de wettelijke ontslaggronden zich voordoen. De overheid kan "haar" commissaris ontslaan wanneer zij dit wenselijk acht. ${ }^{96}$ Haar bevoegdheid is in zoverre vergelijkbaar met die van de ava in het gewone model.

\section{§15. Behoorlijke samenstelling}

\section{Algemeen}

Om zijn taak naar behoren te kunnen vervullen dient de rvc behoorlijk te zijn samengesteld. De eis van behoorlijke samenstelling rust op structuurvennootschappen als een wettelijke verplichting. De rvc van een structuurvennootschap kan een kandidaat-commissaris niet benoemen indien benoeming van betrokkene zou betekenen dat de raad "niet naar behoren zal zijn samengesteld" (art. 158 lid 6). Ook indien na benoeming een commissaris een kwaliteit zou blijken te missen die noodzakelijk is opdat de rvc naar behoren is samengesteld, kan dit gebrek een reden zijn tot ontslag (art. 161 lid 2). Doch de verplichting tot behoorlijke samenstelling geldt ook voor andere vennootschappen ongeacht het wettelijk regime waaraan zij zijn onderworpen. Voor zover de term 'onbehoorlijk' verstaan wordt als 'rechtens ongeoorloofd', spreekt het voor zich dat noch benoeming ${ }^{97}$ noch handhaving in het ambt in strijd met het recht mogen geschieden. Hieruit volgt dat elke raad van commissarissen naar behoren moet zijn samengesteld.

De moeilijkheid ligt niet in de constatering dat de raad behoorlijk moet zijn samengesteld maar in de bepaling van hetgeen deze verplichting in concreto betekent. Hierover zou ik het volgende willen opmerken.

In de eerste plaats lijkt mij dat op dit punt verschil bestaat tussen gewone en structuurvennootschappen. In het gewone model komt de bevoegdheid tot benoeming in beginsel toe aan de algemene vergadering. Wel kan op grond van art. 143 statutair worden bepaald dat ten hoogste eén derde van de raad door een andere instantie zal worden benoemd. In het structuurmodel worden commissarissen door de rve benoemd, met dien verstande dat in de statuten aan een overheidsinstantie het recht kan worden verleend om

96. Zie overigens over de positie van de overheidscommissaris hierna $\$ 16$,III.

97. Ten aanzien van bestuurders is dit ook door de Hoge Raad bepaald, HR 13 februari 1942, NJ 1942, 360 (Baus / De Koedoe). 
één of meer commissarissen te benoemen. In alle gevallen betekent de verplichting tot behoorlijke samenstelling mijns inziens tweeërlei. In de eerste plaats houdt zij in dat de benoemingsbevoegdheid uitgeoefend dient te worden in overeenstemming met de eisen van redelijkheid en billijkheid (art. 8). In de tweede plaats brengt zij mede dat het orgaan dat over de commissariële ambten beschikt mede dient te werken aan het ontslag van een commissaris wanneer handhaving van de aanstelling van betrokkene zou inhouden dat de raad niet naar behoren zou zijn samengesteld. Ook in dit tweede geval is het dus een kwestie van het te goeder trouw uitoefenen van de betrokken bevoegdheid, i.c. de ontslagbevoegdheid.

Dat de verplichting tot behoorlijke samenstelling steeds neerkomt op het te goeder trouw uitoefenen van de benoemings- en ontslagbevoegdheid, betekent echter niet dat zij altijd tot dezelfde resultaten moet leiden. Indien de bevoegdheidsuitoefening door verschillende organen geschiedt, is het mogelijk dat de organen bij de bevoegdheidsuitoefening tot verschillende resultaten komen. In het algemeen zou ik willen stellen dat, terwijl commissarissen hun bevoegdheden dienen uit te oefenen in het belang van de vennootschap, de leden van de andere organen zich, bij het beoordelen van de eis van behoorlijke samenstelling, kunnen laten leiden door hun persoonlijk oordeel. Dat het oordeel van de raad van commissarissen en dat van de ava -en hetzelfde geldt mutatis mutandis voor de andere i.c. bevoegde organen- niet parallel behoeft te lopen is reeds eerder betoogd. ${ }^{98}$

De eis van behoorlijke samenstelling verwijst naar de taakvervulling van commissarissen. Dat de raad naar behoren dient te zijn samengesteld houdt in dat hij in staat moet zijn wettelijke en statutaire bevoegdheden behoorlijk vit te oefenen. Voor zover de toezichthoudende taak van commissarissen behoorlijk vervuld wordt, kan men er van uitgaan dat de raad naar behoren is samengesteld. Zoals in het eerste hoofdstuk is gesteld, is de rentabiliteit van het vermogen bij een kapitalvennootschap de eerste maatstaf van een behoorlijke taakvervulling.

De behoorlijke samenstelling is niet een in de tijd gefixeerd gegeven. $\mathrm{Zij}$ strekt zich uit tot de gehele periode waarin de betrokken raad zijn taak dient te vervullen. Van de problematiek van de behoorlijke samenstelling dient te worden onderscheiden het geval dat onder zekere omstandigheden de raad als geheel of enkele zijner leden niet in staat zijn de commissariële taak uit te oefenen. Dit geval kan zich bijvoorbeeld voordoen wanneer ten gevolge van een bepaalde transactie de rvc of enkele commissarissen een tegenstrijdig belang hebben met de vennootschap. Het ongeschikt zijn

98. Zie $\$ 4$, III. 
terzake van bepaalde transacties brengt echter niet de onbehoorlijke samenstelling van de raad met zich mee, omdat zijn taakvervulling niet alleen betrekking heeft op de gewraakte transactie maar op het geheel van transacties die plaatsvinden gedurende de functieperiode. Wel is het mogelijk dat een blijvende situatie van tegenstrijdig belang onbehoorlijke samenstelling van de raad tot gevolg heeft. Een dergelijke situatie is niet ondenkbaar bij een raad van commissarissen die slechts uit eén lid bestaat.

\section{Benoembaarheid}

Het criterium voor de behoorlijkheid van de (kandidaat)commissaris is zijn geschiktheid om de toezichthoudende taak te vervullen. Een uitputtende behandeling van de situaties waarin deze geschiktheid ontbreekt -en betrokkene derhalve niet rechtsgeldig tot commissaris kan worden benoemd c.q. zijn aanstelling niet kan worden gehandhaafd- wordt hier niet gegeven. Ik zal mij beperken tot enkele situaties die om uiteenlopende redenen speciale aandacht hebben gekregen in rechtspraak en literatuur.

De wet stelt enkele voorwaarden aan het commissariaat. Of juister gezegd, zij beschouwt bepaalde personen ongeschikt voor de functie van commissaris. Benoeming van deze personen is dan ook verboden. Onderscheiden kan worden tussen absolute en relatieve verboden. Absolute verboden gelden in alle vennootschappen ongeacht het toepasselijke rechtsregime. De wet noemt twee absolute verboden, namelijk de hoedanigheid van rechtspersoon (art. 140 lid 1) en de leeftijdsgrens van 72 jaar (art. 142 lid 4). Daarnaast gelden voor structuurvennootschappen de relatieve verboden van art. 160. Volgens dit artikel kunnen niet tot structuurcommissaris worden benoemd, kort gezegd, werknemers in dienst van de vennootschap of van een afhankelijke maatschappij en vakbondsbestuurders die met de vennootschap over arbeidsvoorwaarden onderhandelen. Andere expliciete verboden bevat Boek $2 \mathrm{BW}$ niet.

De opsomming van art. 160 kan echter niet als limitatief worden beschouwd. ${ }^{99}$ Dezelfde reden die de wetgever beweegt om de verboden vast te leggen, geldt ten opzichte van andere omstandigheden die niet expressis verbis worden genoemd. Deze reden is dat de betrokken persoon zijn taak niet naar behoren zal kunnen vervullen. De persoon die zich in deze omstandigheden bevindt kan niet als commissaris worden benoemd. Dit verbod volgt uit het systeem van de wet. Het is mijns inziens. niet minder verplichtend dan een expliciet verbod, hoewel het moeilijker is vast

99. Vgl. ook Maeijer (1972), blz. 19. 
te stellen. Een voorbeeld van een dergelijk verbod biedt de incompatibiliteit van bestuurderschap en commissariaat in dezelfde vennootschap. Deze incompatibiliteit ligt in de onverenigbaarheid van de leidinggevende en de toezichthoudende functie. ${ }^{100}$ De functies zijn onverenigbaar omdat het als een rechtsbeginsel geldt dat een persoon over zijn eigen daden geen controle ten behoeve van een derde (i.c. de rechtspersoon) kan uitoefenen. De commissariële controle vereist een zekere onafhankelijkheid ten opzichte van hetgeen gecontroleerd wordt. Dit nu wordt onmogelijk geacht met betrekking tot het eigen handelen. ${ }^{101}$

Het is op voorhand niet te zeggen in hoeverre de eis van behoorlijke samenstelling mede brengt dat een kandidaat niet kan worden benoemd, dan wel een reeds benoemde commissaris zijn functie moet neerleggen. Dit zal het geval zijn indien bij benoeming of handhaving in het ambt, de rvc niet of minder goed in staat is om zijn taak behoorlijk te vervullen. Aan de bevoegde organen komt in deze een ruime beoordelingsmarge toe. Voorbeelden van situaties die er toe kunnen leiden dat de raad niet naar behoren is samengesteld zijn: de aanwezigheid van kruiscommissariaten, de samenval van de functie van commissaris en bestuurder van elkaar beconcurrerende vennootschappen, de wijziging van de samenstelling van de raad ten gevolge van de toetreding van nieuwe leden (bijvoorbeeld in geval van fusie), het missen door één of meer commissarissen van een voor de raad noodzakelijk geachte kwaliteit. Tal van omstandigheden kunnen een rol spelen bij de beoordeling van de eis van behoorlijke samenstelling. Ik noem als voorbeelden: de verdeling van het aandelenkapitaal en de aard van de aandeelhouder(s), het aantal leden van de raad, het al of niet zijn van structuurvennootschap, het aanwezig zijn van werknemers en hun aantal, de aard van de onderneming.

In de literatuur bestaat geen eenstemmigheid over de wenselijkheid van de incompatibiliteitsregeling neergelegd in art. 160. De duidelijke bewoordingen van de wetgever verklaren wellicht waarom dit artikel in de praktijk niet of nauwelijks tot problemen lijkt te leiden.

Het artikel is door de Structuurwet ingevoerd. Als reden voor de invoering werd in de MvT aangevoerd, in aansluiting op het voorontwerp van de Commissie Verdam (art. $50 \mathrm{~m}$ ), dat "deze personen in het algemeen niet geacht kunnen worden voldoende vrij en onafhankelijk te staan tegen-

100. Evenzo Handhoek, nr. 283. Uitgebreid over het onderwerp Drion (1993), blz. 87 e.v.

101. In andere stelsels kunnen de toezichthoudende en de leidinggevende functie door hetzelfde orgaan worden uitgeoefend, bijv. in het geval van de Engelse board of directors. Maar ook daar dient een scheiding te zijn tussen de personen die de verschillende taken uitoefenen. Vgl, art. $21 a$ ontwerp 5 de EG-richtlijn. 
over de leiding van de vennootschap en haar personeel". ${ }^{102}$ Het door sommige kamerleden tegen deze motivering aangedragen bezwaar maakt duidelijk hoe de door de wetgever beoogde onafhankelijkheid dient te worden verstaan. Gesteld werd ${ }^{103}$ dat niet was in te zien waarom een aandeelhouder die $10 \%$ van het kapitaal der vennootschap bezit wel onafhankelijk moet worden geacht maar niet de bestuurder van een vakbond die een tiende van het personeel vertegenwoordigt. Apodictisch antwoordde de minister dat er hier geen sprake is van een "soortgelijke situatie".

De onafhankelijkheid dient mijns inziens niet als een feitelijk gegeven te worden verstaan, in die zin dat de betrokkene geen belang heeft ten opzichte van de vennootschap. Ware dit het criterium dan zou er inderdaad geen reden zijn om onderscheid te maken tussen werknemers en aandeelhouders. Wellicht zou zelfs kunnen worden gesteld dat, althans bij grote vennootschappen, werknemers doorgaans meer belang hebben bij de gang van zaken in de vennootschap dan aandeelhouders. ${ }^{104}$ De onafhankelijkheid wordt bepaald door het bezitten van een rechtspositie die de uitoefening van de toezichthoudende taak niet belemmert. In de opvatting van de wetgever mist de werknemer deze onafhankelijkheid omdat hij onderworpen is aan de zeggenschap van personen over wier handelen hij toezicht dient te houden. ${ }^{105}$ Voor de vakbondsbestuurder geldt in zoverre niet hetzelfde daar hij niet in een gezagsverhouding staat ten opzichte van de rechtspersoon. Wat hem naar het oordeel van de wetgever kennelijk ongeschikt maakt voor de functie van commissaris, is het feit dat hij tegenover de vennootschap staat wanneer over de arbeidsvoorwaarden van het personeel wordt onderhandeld. Dit "tegenover de vennootschap staan" beschouwt de wetgever als een omstandigheid die aan een onafhankelijke taakuitoefening in de weg staat. ${ }^{106}$

Van de aandeelhouder kan niet worden gezegd dat zijn verhouding tot de vennootschap hem ongeschikt maakt voor de commissariële functie. $\mathrm{Nu}$ naar mijn mening de vennootschap primair moet worden beschouwd als een instrument om de belangen van de aandeelhouders te dienen, spreekt het voor zich dat aandeelhouders zitting kunnen nemen in het orgaan dat toezicht dient te houden op de realisatie van het vennootschappelijk doel.

102. Maeijer, Wetsgeschiedenis, IXf - Art. 52j (III) - 1 .

103. Wetsgeschiedenis, t.a.p.

104. In dit opzicht in gelijke zin Van Haren, TVVS 1977, blz. 133.

105. In gelijke zin Van Schilfgaarde (1984), blz. 6; Rood (1989), blz. 230. Kritisch, hoewel niet steeds om dezelfde redenen: Prof. mr. B.M. Teldersstichting, De Raad van Commissarissen in de onderneming van morgen, Geschrift nt. 38, 1981, blz. 43; Van den Burg. TVVS 1981, blz. 238.

106. Of handhaving van de verboden van art. 160 lege ferenda zinvol is, kan in het midden worden gelaten. 
Dit wil niet zeggen dat het toezicht door aandeelhouders moet worden uitgeoefend, of dat de raad van commissarissen niet naar behoren zou zijn samengesteld indien daarin geen aandeelhouder zitting zou nemen. In het algemeen zou ik willen stellen dat bij gewone vennootschappen aan aandeelhouders de principiële vrijheid toekomt om de persoon te benoemen die hen goeddunkt. Statutair zou zelfs kunnen worden bepaald dat slechts aandeelhouders tot commissaris kunnen worden benoemd. ${ }^{107} \mathrm{Bij}$ structuurvennootschappen geldt dat de benoemingsbevoegdheid bij de rvc berust en dat niemand enkel op grond van zijn kapitaaldeelneming recht heeft op een plaats in de $\mathrm{rvc}^{\mathrm{108}}$, maar voor zover de vennootschap primair de belangen van de aandeelhouders dient lijkt mij dat de rvc niet de wensen van de kapitaalverschaffers kan negeren. Ik ben dan ook een andere mening toegedaan dan Van Schilfgaarde waar hij schrijft: "De omstandigheid dat iemand een groot pakket aandelen in de vennootschap houdt kan een vermoeden opleveren dat hij ongeschikt is om als commissaris te fungeren, zeker wanneer dit bij wijze van belegging geschiedt." ${ }^{109}$ Naar mijn mening zou eerder moeten worden aangenomen dat het aandeelhouderschap een vermoeden van geschiktheid inhoudt. Er kunnen omstandigheden zijn waarin benoeming achterwege dient te blijven, bijvoorbeeld omdat de kandidaat ten enenmale ongeschikt is of omdat gegronde redenen zijn om te oordelen dat de kandidaat zijn ambt zal misbruiken. Het is aan het benoemend orgaan om te beoordelen in hoeverre deze omstandigheden zich voordoen. Aan de 'principiële geschiktheid' van aandeelhouders voor de vervulling van de commissariële functie doen deze pathologische gevallen niet af.

De onafhankelijkheid waarmee de grootaandeelhouder-commissaris zijn taak dient te vervullen houdt mijns inziens niet in dat hij bij zijn functievervulling geen rekening zou mogen houden met zijn aandeelhouderschap. De vereiste onafhankelijkheid is naar mijn mening een persoonlijke kwaliteit van de commissaris. In de woorden van een bekend bindend advies ${ }^{100}$ : "dat bindend adviseurs het desideratum van de onpartijdigheid

107. Zie over kwaliteitseisen hierna $\$ 15$,III.

108. Anders Scholten (1976), blz. 141, die stelt dat de rvc van een dochtervennootschap die onderworpen is aan het structuurregime "zeker niet naar behoren is samengesteld, a] [s] niet éen of enkele vertegenwoordigers van de moedermaatschappij er deel van uitmaken." M.i, is dit te algemeen gesteld. Of er vertegenwoordigers van de moeder in de rvc van de dochter aanwezig moeten zijn staat naar mijn mening voornamelijk ter beoordeling van de moeder zelf, die haar oordeel kenbaar kan maken door middel van het aanbevelings- en bezwaarrecht.

109. (1984), blz. 6 .

110. Bindend advies d.d. 27 december 1976, TVVS 1977, blz. 141 e.v. Het advies ging weliswaar niet over de benoeming van een grootaandeelhouder, maar de daarin

(Wordt vervolgd...) 
aldus verstaan, dat betrokkene ongeacht zijn herkomst en zijn persoonlijke instelling in staat moet worden geacht tot het onpartijdig oordeel, waartoe zijn functie van commissaris in het Nederlandse vennootschapsstelsel -dus ook in het structuursysteem, dat behartiging van deelbelangen in de raad van commissarissen beoogt te voorkomen- hem verplicht." Onafhankelijkheid van de commissarissen houdt mijns inziens in: het vermogen om toezicht te houden op de vervulling van het vennootschappelijke doel. Voor zover dit doel samenvalt met de doelstellingen die de aandeelhouder als zodanig nastreeft kan de commissaris ratione materiae niet onafhankelijk zijn in de zin waarin deze onafhankelijkheid doorgaans wordt verstaan. Naar ik meen behoeft de grootaandeelhouder die tot commissaris wordt benoemd geen gedaanteverandering te ondergaan. Dit is met name het geval indien hij de enig aandeelhouder is. In de uitoefening van zijn bevoegdheden als commissaris spreekt het dan voor zich dat hij bepaaldelijk rekening houdt met zijn belangen als aandeelhouder.

Om de zojuist genoemde reden bestaat mijns inziens geen bezwaar tegen de benoeming van bestuurders of andere werknemers van de moedervennootschap (de enig aandeelhouder dus) als commissaris in dochtervennootschap. Juist in concernverhoudingen blijkt mijns inziens hoezeer de hier verdedigde instrumentaliteit van de vennootschap een feit is. ${ }^{11}$

Overigens is de wetgever niet consequent geweest in zijn appreciatie van de ongeschiktheid van werknemers en vakbondbestuurders voor wat betreft de uitoefening van het commissariaat. Men zou immers moeten aannemen dat de redenen van het verbod gelding hebben ongeacht het vennootschapsregime omdat zij betrekking hebben op de functievervulling door de werknemer-commissaris, welke gelijk is in alle vennootschapsmodellen.

110.(...vervolg)

vervatte overwegingen omtrent de vereiste onafhankelijkheid bij de taakvervulling zijn i.c. evenzeer van toepassing.

111. Hoewel om andere redenen, wordt de benoeming van de bestuurder van de moeder ook mogelijk geacht door Scholten (1976), blz. 141; Bindend Advies d.d. 27 december 1976, TVVS 1977, blz. 141 e.v. en Van der Grinten, De NV 55 (1977), blz. 109 e.v. Anders Van Haren, TVVS 1977, blz. 129. Het Bindend Advies maakt mijns inziens ten onrechte onderscheid tussen twee soorten afhankelijkheid van de commissarissen ten opzichte van de aandeelhouders (r.o. 21): "... dat weliswaar ten opzichte van een dochtervennootschap een directeur van de moedervennootschap in de onderlinge concernverhouding een representant van de aandeelhoudster is, doch dat hij bepaaldelijk niet, zoals een groot-aandeelhouder zelf, kan worden beschouwd als vertegenwoordiger van de kapitaalverschaffers van het concern als geheel en in tegendeel als directeur van de moedervennootschap heeft te maken voor alle bij het concern betrokken belangen." (Mijn curs. JMBF). Het is niet in te zien waarom het aandeelhouderschap van de moedervennootschap principieel anders zou zijn dan dat van de kapitaalverschaffers van het concern. 
Aangenomen mag echter worden dat ondanks deze gelijkheid in taakstelling de verboden van art. 160 slechts op structuurvennootschappen van toepassing zijn. Dit omdat hun zin dubieus is, omdat zij een beperking inhouden van de autonomie van de rechtsgenoten, en als zodanig restrictief moeten worden geïnterpreteerd en omdat zij ingevoerd zijn door de Structuurwet en dus met enige "goede wil" aangenomen kan worden dat de wetgever de verboden heeft willen beperken tot de vennootschappen waarvoor dit regime geldt.

\section{Kwaliteitseisen}

De bevoegde vennootschapsorganen zijn in het gewone model vrij om over de vennootschappelijke ambten te beschikken. In deze ambten kunnen de personen worden benoemd die door de bevoegde instantie geschikt worden geacht. Dezelfde vrijheid bestaat ten aanzien van de voortzetting van de aanstelling. Aan de aanstelling kan te allen tijde een einde worden gemaakt. Onze wet staat echter toe dat de bevoegdheid van het orgaan in kwestie onder bepaalde omstandigheden beperkt wordt. Statutair kan worden bepaald dat niet iedere persoon doch slechts personen met zekere kwaliteiten mogen worden benoemd. Voorts kunnen de statuten het ontslagbesluit in zoverre aan banden leggen dat voor het nemen van dit besluit versterkte meerderheids- en quorumeisen gelden. Deze beperkingen zijn een gevolg van de autonomie van de rechtsgenoten om de hun toekomende bevoegdheden naar eigen inzicht uit te oefenen. Voor zover deze vrijheid bestaat, kan er geen bezwaar tegen zijn dat de rechtsgenoten zichzelf beperkingen opleggen. Op deze plaats zou ik nader willen ingaan op de problematiek van de kwaliteitseisen voor commissarissen.

De Departementale Richtlijnen geven enige voorschriften omtrent kwaliteitseisen bij gewone vennootschappen. ${ }^{112}$ De voorschriften hebben tot doel te voorkomen dat de invulling van de betrokken vennootschappelijke ambten uiterst bezwaarlijk wordt. ${ }^{113}$ De statuten kunnen de kring van

112. Dep. Richtl. §6: "De statuten mogen eisen stellen waaraan $(\ldots)$ commissarissen moeten voldoen. (...) De statuten mogen aan een vennootschapsorgaan of aan derden toestaan ontheffingen van de gestelde vereisten te verlenen. De gestelde eisen mogen de kring van kandidaten niet te zeer beperken, tenzij de statuten bepalen dat de beperking kan worden doorbroken. De statuten mogen aan deze doorbreking geen strengere eisen stellen dan is toegestaan voor de besluitvorming tot het ontnemen van de bindende kracht aan een voordracht voor benoeming van bestuurders of commissarissen."

113. Aldus expliciet Dep. Richtl. $1976 \$ \$ 28,36$. 
benoembare personen zoveel beperken als naar het oordeel van de rechtsgenoten wenselijk is. Ook de meest vergaande beperking is mogelijk: de leden van de raad van commissarissen kunnen in de statuten met naam worden genoemd. Statutaire kwaliteitseisen zijn in de ogen van het Departement slechts toelaatbaar indien zij kunnen worden doorbroken met dezelfde meerderheids- en quorumeisen als die welke wettelijk als uiterste grens gelden voor het ontnemen van het bindend karakter aan een voordracht tot benoeming (art. 133 lid 2). Dezelfde grens geldt voor het ontslag van bestuurders en commissarissen (art. 134 lid 2). Het is verdedigbaar dat kwaliteitseisen voor benoembaarheid aan dezelfde beperkingen worden onderworpen als die welke gelden voor bindende voordrachten en voor ontslag. De strekking van de artt. 133 en 134 geldt ook voor de doorbreking van kwaliteitseisen. De minderheid (vertegenwoordigend minder dan een derde van het geplaatste kapitaal) dient niet in staat te zijn om de benoeming van een commissaris te blokkeren. Ik meen dat dit beginsel voor elke benoeming en elk ontslag geldt, hoewel uit de bewoordingen van de Departementale Richtlijnen $a$ contrario afgeleid zou kunnen worden dat de mogelijkheid tot doorbreking van de kwaliteitseis niet geldt voor kwaliteitseisen die de kring van benoembare commissarissen "niet te zeer beperken". De beperkingsgraad van de kwaliteitseis kan echter niet aan de dwingende bepaling van de artt. 133 en 134 derogeren. Ware dit anders, dan zouden de rechtsgenoten kunnen bepalen wanneer de in deze artikelen aangegeven grens geldt.

De Hoge Raad heeft zich uitgelaten over de doorbreking van een statutaire kwaliteitseis. ${ }^{114} \mathrm{Bij}$ de vennootschap in kwestie bestond de eis hierin, dat om tot directeur te kunnen worden benoemd, de kandidaat een bepaald aantal aandelen diende te bezitten. De Hoge Raad overwoog hieromtrent: "dat de vraag hoe ver een dergelijke beperking kan gaan zonder in strijd te komen met het wettelijk stelsel volgens het welk in beginsel de keuze van de bestuurders aan de algemene vergadering toekomt, voor een algemene beantwoording niet vatbaar is." Geheel juist lijkt mij deze overweging niet. Immers, de grenzen van de benoemingsvrijheid van de ava worden, in de opvatting van de Hoge Raad, bepaald door de beperkingsgraad van de kwaliteitseisen. Hoe groter de beperking van de kwaliteitseis, des te sneller zal moeten worden aangenomen dat de eis ongeoorloofd is. De geoorloofdheid van de beperking moet dan aan de hand van de concrete eisen worden vastgesteld, hetgeen er op neer komt dat de rechtsgenoten zelf de grenzen van de benoemingsmacht van de ava vaststellen. Het uitgangspunt moet naar mijn mening het omgekeerde zijn. Mij dunkt dat voor de vraag, in hoeverre de ava haar benoemingsvrijheid

114. HR 19 maart 1976, NJ 1978, 52 (Van Rees). 


\section{KWALITEITSEISEN}

behoudt, niet beslissend is hoe ver de kwaliteitseis op zich mag gaan, maar de vraag onder welke voorwaarden de ava krachtens de wet een kwaliteitseis naast zich neer kan neerleggen. Op grond van het in de artt. 133 en 134 neergelegde beginsel kan de algemene vergadering telkens als de in die artikelen genoemde grenzen worden bereikt tot benoeming of ontslag overgaan. Gegeven deze macht zijn rechtsgenoten vrij om binnen die grens de bevoegdheid van de ava naar eigen inzicht te beperken. Mijns inziens bestaat dan geen bezwaar tegen de meest stringente eisen omdat deze steeds door de ava kunnen worden doorbroken. Dit is uiteindelijk ook het standpunt van het departement.

De Hoge Raad vervolgt dan: "dat aan het aandelenbezit van de te benoemen bestuurder niet kon worden voldaan alléen ten gevolge van het feit dat een minderheid van de aandeelhouders met gebruikmaking van een blokkeringsbepaling in de statuten de overdracht van aandelen aan de te benoemen bestuurder kon beletten en in feite heeft belet; dat onder die omstandigheden -gelet in het bijzonder op hetgeen in het tweede lid van art. 48a [art. 133] is bepaald- met het wettelijk stelsel van benoeming van bestuurders door de algemene vergadering van aandeelhouders in ieder geval als onverenigbaar moet worden beschouwd, dat een zodanig statutair vereiste voor de benoembaarheid van een bestuurder een benoeming zou kunnen beletten, waarvoor de algemene vergadering zich met twee derde der uitgebrachte stemmen, vertegenwoordigende meer dan de helft van het geplaatste kapitaal, heeft uitgesproken." Hier geeft de Hoge Raad een beslissing over de toepasselijkheid van de betrokken kwaliteitseis en oordeelt dat de eis i.c. niet geldt wegens de gedraging van de minderheidsaandeelhouder die, naar het oordeel van de Hoge Raad, ten onrechte de voor benoeming noodzakelijke overdracht van aandelen blokkeert. In werkelijkheid gaat het hier niet om de vaststelling van de bevoegdheid van de algemene vergadering om de betrokken kwaliteitseis te doorbreken; het beroep op art. 133 is dan ook onjuist. Het gaat hier om een geval van rechtsmisbruik door de minderheidsaandeelhouders. ${ }^{115}$

Bij structuurvennootschappen staat het departement het gebruik van statutaire kwaliteitseisen niet toe. Het departementale standpunt is het gevolg van een door de Werkgroep Vennootschapsrecht uitgebracht advies over deze materie. ${ }^{116}$ Kort samengevat, baseert de Werkgroep haar standpunt op het volgende:

115. Evenzo Van Oven WPNR 5571 (1981), blz. 448.

116. Advies d.d. 18 november 1974, gepubliceerd in De NV 53 (1975), blz. 19 e.v. Het advies is besproken door Treurniet in hetzelfde tijdschrift, blz. 36 e.v. 
a) De strekking van de Structuurwet verzet zich tegen statutaire kwaliteitseisen voor commissarissen waar de wet het stellen van bindende voordrachtsrechten voor benoeming verbiedt.

b) Het aangeven van grenzen waarbinnen kwaliteitseisen geoorloofd zijn heeft iets willekeurings in zich. Aan de wet kan bovendien geen indicatie worden ontleend waaruit de toelaatbaarheid van dergelijke eisen zou volgen. Aangenomen moet daarom worden dat kwaliteitseisen in alle omstandigheden door de wet als ontoelaatbaar worden beschouwd.

c) Het stellen van kwaliteitseisen zou afbreuk doen aan de exclusieve taak van de SER (thans de OK) om de behoorlijkheid der samenstelling van rvc'en te beoordelen.

De vraag of statutaire kwaliteitseisen verenigbaar zijn met het systeem van de Structuurwet is in wezen een vraag naar het bestaan van de autonomie van de rechtsgenoten. Indien deze autonomie bestat, dit wil zeggen indien de rechtsgenoten op dit punt vrij zijn de inhoud der statuten te bepalen, kan de vraag worden gesteld hoe ver de autonomie zich uitstrekt. Mocht het onder a) weergegeven argument juist zijn, dan dienen de overige argumenten slechts ter bevestiging van de conclusie dat statutaire kwaliteitseisen in strijd zijn met de Structuurwet.

Met de Werkgroep zou ik inderdaad willen stellen dat kwaliteitseisen tot dezelfde rechtsgevolgen leiden als de bindende voordrachten die door art. 158 lid 2 verboden worden verklaard, en dat zij daarom als onverenigbaar met het wettelijk systeem te beschouwen zijn. Het verbod van art. 158 lid 2 beoogt te voorkomen dat de rvc in de uitoefening van de benoemingsbevoegdheid gebonden is aan het oordeel van derden. ${ }^{117}$ Het statutair stellen van eisen waaraan commissarissen dienen te voldoen brengt met zich mee dat commissarissen bij de benoeming gebonden zijn aan de eisen welke door een ander orgaan zijn gesteld. Indien men de eigen verantwoordelijkheid van de rvc bij de uitoefening van de benoemingsbevoegdheid ${ }^{118}$ aanvaardt, moet de conclusie zijn dat de bemoeienis van derden onverenigbaar is met de dwingende toekenning van bevoegdheden en dat het stellen

117. Vgl. de toelichting op art. $50 h$ van het ontwerp van de Commissie Verdam: "In de opzet van het ontwerp past het niet de keuze voor commissarissen te beperken door een bindende voordracht van enige andere instantie" (blz. 124). Het ontwerp-artike! heeft betrekking op de benoeming van bestuurders. De ratio van de bepaling geldt echter evenzeer voor andere benoemingen.

118. Dit geldt op grond van de artt. 158 lid 2 en 162 zowel voor de bevoegdheid tot benoeming van commissarissen als voor de benveming van bestuurders. Anders Van der Grinten, noot onder de ministeriële beschikking d.d. 7 april 1987 (De Porceleyne Fles), De NV 66 (1988), blz. 32. 


\section{KWALITEITSEISEN}

van statutaire kwaliteitseisen in strijd is met het stelsel van de Structuurwet.

Aan Treurniet moet worden toegegeven dat het verbod van art. 158 lid 2 en de hier aan de orde zijnde statutaire kwaliteitseisen niet zonder meer op een lijn kunnen worden gesteld. Hij schrijft: "Het ligt voor de hand dat een zodanige voordracht niet is toegelaten omdat, indien het anders was, de benoeming, weliswaar niet formeel maar in feite, niet door de raad van commissarissen, maar door een ander zou geschieden. De conclusie echter, dat "derhalve" ook de kring van personen waaruit commissarissen kunnen worden gekozen, niet op enigerlei wijze door of krachtens de statuten van de vennootschap kan worden beperkt, is allerminst dwingend." 119 Zie ik het goed, dan ligt naar het oordeel van Treurniet het verschil tussen bindende voordrachten en kwaliteitseisen in het feit dat de voordrachten de benoemingsvrijheid van commissarissen vergaand beperken en kwaliteitseisen niet. Dit is echter evenmin een dwingende conclusie. Immers, de voordracht kan een groot aantal namen bevatten waaruit commissarissen kunnen kiezen en de kwaliteitseisen kunnen dusdanig concreet zijn dat slechts één persoon voor benoeming in aanmerking komt. Bij het al dan niet geoorloofd zijn van deze regelingen gaat het echter niet om het meer of minder stringente karakter van de regeling, maar om het feit dat zij, gelijk de bindende voordrachten, de beoordelingsvrijheid van de rvc überhaupt beperken. Dit is wat de wet mijns inziens wil tegengaan. Met dit doel heeft zij de autonomie van de rechtsgenoten op dit punt willen beknotten, en wel in die zin dat terzake van de benoeming van commissarissen aan aandeelhouders van structuurvennootschappen slechts een aanbevelings- en een bezwaarrecht toekomt. Nu de autonomie van rechtsgenoten door de wet is uitgesloten, moet met de Werkgroep Vennootschapsrecht ${ }^{120}$ worden geconcludeerd dat kwaliteitseisen: "in alle omstandigheden -en niet slechts in bepaalde gevallen op grond van aard of inhoud van de betrokken kwaliteitseis- ontoelaatbaar zijn." Ook indien de kwaliteitseisen dermate ruim zouden zijn dat er 'voldoende' beoordelingsvrijheid aan commissarissen zou overblijven -bijvoorbeeld de eis dat commissarissen ouder dan 29 jaar dienen te zijn- zijn zij ex lege verboden. Het feit dat kwaliteitseisen "functioneel zijn ten opzichte van het belang van de vennootschap"121 maakt de eisen niet geoorloofd. Anders geldt slechts ten opzichte van die eisen welke volgens vaste jurisprudentie geboden zijn. ${ }^{122}$ Alsdan zijn de

119. De NV 53 (1975), blz. 37.

120. Advies, t.a.p., blz. 20.

121. Aldus Maeijer (1973), blz. 18.

122. Zo bijvoorbeeld kan de eis van het Nederlanderschap en ingezetenschap in het licht van de 'jurisprudentie' van de SER en de OK in bepaalde gevallen noodzakelijk worden geacht. Vgl. SER-beschikking d.d. 16 maart 1979, (De NV 57 (1979), blz.

(Wordt vervolgd...) 
kwaliteitseisen niet anders dan een weergave van hetgeen rechtens geldt. Om deze reden zijn zij overigens zinloos.

De ratio van het verbod van statutaire kwaliteitseisen brengt anderzijds met zich mee dat deze eisen wel toelaatbaar zijn wanneer zij door dezelfde raad van commissarissen, bijvoorbeeld krachtens reglement, worden gesteld. In dit geval oefent de raad zijn bevoegdheid autonoom uit. Daarentegen zou kunnen worden opgemerkt dat de door de rvc gestelde eisen, het aanbevelingsrecht van ava en or kunnen frustreren omdat de aanbevolen kandidaat mogelijk niet beantwoordt aan de door de rvc gestelde eisen. Dit bezwaar miskent mijns inziens het feit dat de benoemingsbevoegdheid van de raad mede inhoudt de bevoegdheid om zelfstandig te bepalen aan welke criteria de te benoemen kandidaat dient te voldoen. Dat ava en or andere criteria hanteren doet aan de bevoegdheid van de rvc niets af. Indien ava en or menen dat het benoemingsbeleid van de rvc niet correct is, dienen zij zulks, door middel van het bezwaarrecht, aan de OK voor te leggen. ${ }^{123}$

Het probleem van de statutaire kwaliteitseisen bij structuurvennootschappen wijst eens te meer op de problematiek van het wezen der vennootschap. Het stellen van kwaliteitseisen is, onder andere blijkens de ontheffingspraktijk ex art. 156 waarop hierna zal worden ingegaan, een in de vennootschapspraktijk gevoelde noodzaak. Daar de vennootschap voor een bepaald doel wordt opgericht, wensen de rechtsgenoten zoveel mogelijk te bewerkstelligen dat de personen, die de vennootschappelijke ambten bekleden, aan de eisen beantwoorden die volgens de rechtsgenoten nodig zijn om het vennootschappelijke doel te realiseren. Terecht wordt dan ook aan het slot van het advies van de Werkgroep Vennootschapsrecht opgemerkt dat door middel van de statutaire doelomschrijving indirect kwaliteitseisen aan de commissarissen kunnen worden gesteld. De vennootschappelijke bevoegdheden -en dus ook de bevoegdheid tot benoeming van commissarissenrichten zich op de verwezenlijking van het vennootschappelijke doel, en in zoverre is het oordeel van de commissarissen gebonden aan hetgeen statutair omtrent het doel van de vennootschap bepaald wordt. Ook de OK is bij een eventueel bezwaar van de ava of de or tegen een voorgenomen benoeming gebonden aan de statutaire bepaling, omdat ten aanzien van de bepaling van het vennootschappelijke doel de rechtsgenoten wel autonoom zijn. Zo zou bijvoorbeeld de algemene vergadering c.q. de ondernemingsraad van een structuurvennootschap van beroepsbeoefenaren naar alle

\section{2.(...vervolg)}

94 e.v., N.S.E.M.). Zie in dit verband Van der Burg (WPNR 5610 (1982), blz. 349 e.v.

123. Kennelijk anders Van der Grinten, noot onder de ministeriële beschikking d.d. 28 februari 1978 (PLEM), De NV 56 (1978), blz. 71. 


\section{KWALITEITSEISEN}

waarschijnlijkheid kunnen stellen dat de rvc niet naar behoren is samengesteld indien tot de rvc geen beoefenaar van het beroep in kwestie behoort. Dit impliceert echter niet dat de doelomschrijving als achterdeur kan worden gebruikt om noodzakelijk geachte kwaliteitseisen te stellen. In het stelsel van de Structuurwet zijn de oprichters/aandeelhouders vrij om zelf te bepalen welke activiteit zij zullen ondernemen en het spreekt dan ook voor zich dat de personen die de vennootschappelijke functies vervullen zulks doen met het oog op de realisering van deze activiteit. Maar deze personen doen dit zonder onderworpen te zijn aan de zeggenschap van de aandeelhouders. Zij zijn derhalve niet gebonden aan eisen die naar hun oordeel niet noodzakelijk zijn voor de verwezenlijking van het vennootschappelijke doel. In hoeverre een bepaalde doelomschrijving in wezen een verkapte kwaliteitseis inhoudt is een vraag die in voorkomende geval en door de OK dient te worden beantwoord.

Zoals gezegd, blijkt het verband tussen de kwaliteitseisen en het wezen der vennootschap mede uit de beschikkingspraktijk van de minister van Justitie ex art. 156. ${ }^{124}$ Op grond van dit artikel kan de minister "aan een vennootschap op haar verzoek ontheffing verlenen van een of meer der artikelen 158-164". In de MvT wordt deze bepaling slechts gemotiveerd met de stelling dat er zich andere gevallen zullen voordoen, dan de reeds voorziene wettelijke vrijstellingen, waarin behoefte bestaat aan een uitzondering op het Structuurregime. ${ }^{125}$ Volgens Van der Grinten is "de mogelijkheid tot ontheffing niet gegeven om de strekking en de grondslag van de wettelijke regeling te frustreren, doch juist om deze tot haar recht te laten komen in die gevallen dat de toepassing van de abstracte norm van de wet zou leiden tot resultaten die niet zijn beoogd." 126 Echter, omdat de wetgever de Structuurwet als een algemeen geldende norm heeft gedacht -met concreet in de wet voorziene vrijstellingen- is het niet goed mogelijk criteria te ontwikkelen, aan de hand waarvan zou moeten worden vastgesteld dat de wettelijke regeling niet dient te gelden. Dit is met name het geval wanneer de gevraagde ontheffingen een belangrijk onderdeel van de structuurregeling betreffen. Door de minister zijn de volgende regelingen geoorloofd verklaard: bezwaarrecht van de ava tegen de voorgenomen benoeming van een bestuurder door de rvc -waar nog bij komt dat de rvc

124. De competentie welke door art. 156 aan de Minister wordt toegekend is door deze gedelegeerd aan de Staatssecretaris. De Staatssecretaris neemt zijn beslissing na consultatie van de SER, die op zijn beurt het advies laat behandelen door een ad hoc commissie. De Staatssecretaris blijkt in de praktijk het oordeel van de SERcommissie over te nemen.

125. Maeijer, Wetsgeschiedenis, IXf - Art. $52 \mathrm{f}$ (III) - 1 .

126. Noot onder de ministeriële beschikking d.d. 13 november 1973 (Bouwfonds Nederlandse Gemeenten), De NV 52 (1974), blz. 10. 
door dezelfde ava wordt benoemd ${ }^{127}$, benoeming van een commissaris door een aandeelhouder die geen overheidsinstantie is ${ }^{128}$, benoeming van de voorzitter van de rvc bij de statuten -dus, door de aandeelhouders- ${ }^{129}$, opstellen van kwaliteitseisen voor bestuurders. ${ }^{130}$ De lijst is niet limitatief en er is geen reden om andere ontheffingen in de toekomst uit te sluiten.

Indien men van de ontheffing geen privilege wil maken, dient men te zoeken naar criteria op grond waarvan zij verleend wordt. Beperken wij ons nu tot het vraagstuk van de kwaliteitseisen van commissarissen, dat overigens het onderwerp van de meest voorkomende vrijstellingen vormt, dan kunnen wij stellen dat de motivering van de tot op heden verleende beschikkingen niet veel steun biedt. De ontheffing wordt vaak gemotiveerd met het nogal vaag criterium van de "maatschappelijke aanvaardbaarheid", waarbij mede gelet wordt op andere factoren zoals: de "aard van de onderneming van verzoekster" ${ }^{131}$, de wil om de band tussen onderneming en aandeelhouders ${ }^{132}$ te versterken of het bereiken van een redelijk evenwicht tussen de belangen van de aandeelhouders en de doeltreffendheid van een nieuw te creëren samenwerking binnen de vennootschap. ${ }^{133}$ Het beleid is bovendien niet consistent. Ik noem enkele voorbeelden. Met betrekking tot de beperkingsgraad van kwaliteitseisen wordt in de eerste beschikking ${ }^{134}$ als argument voor de ontheffing mede gesteld dat door de kwaliteitseis de kring van de te benoemen personen niet te zeer wordt beperkt. In latere beschikkingen wordt echter van deze omstandigheid geen melding meer gemaakt. ${ }^{135}$ Met betrekking tot het maximale aantal com-

127. De NV 52 (1977), blz. 105 (Nederlandse Spoorwegen).

128. De NV 63 (1985), blz. 127 (Obragas).

129. De NV 65 (1987), blz. 251 (Electriciteitsbedrijf Zuid-Holland).

130. Het betrof hier overigens niet een vennootschap die een overheidstaak uitvoerde. De NV 66 (1988), blz. 31 (De Porceleyne Fles). Van der Grinten acht in zijn noot onder deze beschikking statutaire kwaliteitseisen voor bestuurders van een structuurvennootschap niet in strijd met de wet. Hiervoor heb ik gesteld dat naar mijn mening tekst en strekking van art. 158 lid 2 en 162 gelijk zijn en dat er dus geen reden is om op dit punt te onderscheiden.

131. Bijvoorbeeld beschikkingen d.d. 28 februari 1978, De NV 56 (1978), blz. 70 (PLEM), d.d. 21 maart 1984, De NV 62 (1984), blz, 226 (Waterleiding Maatschappij Overijssel N.V.), d.d. 16 mei 1984, De NV 63 (1985), blz. 27 (Obragas).

132. Beschikking d.d. 18 juli 1978, De NV 56 (1978), blz, 168 (Bank voor Nederlandse Gemeenten).

133. Beschikking d.d. 2 juni 1989, De NV 69 (1991), blz. 262 (SEP).

134. D.d. 13 november 1973, De NV 52 (1974), blz. 9 (Bouwfonds Nederlandse Gemeenten).

135. Von der Grinten (noot onder beschikking d.d. 23 maart 1987, De NV 65 (1987), blz. 251. Electriciteitsbedrijf Zuid-Holland), merkt hierbij op dat in de praktijk aan het criterium van geringe beperking van de kring waaruit commissarissen kunnen

(Wordt vervolgd...) 
missarissen waarvoor kwaliteitseisen bij sommige overheidsvennootschappen kunnen worden gesteld, bepaalt de minister in 1988 dat het "inmiddels vaste beleidslijn" 136 is dat kwaliteitseisen niet toelaatbaar zijn voor een groter aantal commissarissen dan de kleinst mogelijke meerderheid van de raad. Ten opzichte van deze "vaste beleidslijn" worden echter "incidentele" afwijkingen toegelaten. ${ }^{137}$ Met betrekking tot kwaliteitseisen voor commissarissen die van overheidswege worden benoemd, wordt in 1990 beschikt dat "in verband met gewijzigde maatschappelijke opvattingen" deze eisen "thans bezwaarlijk worden geacht". ${ }^{138}$ Onder deze omstandigheden is het niet doenlijk op het punt van kwaliteitseisen voor commissarissen conclusies te trekken.

Voor zover men over een vast criterium kan spreken, zou men kunnen stellen dat voor ontheffing in aanmerking komen vennootschappen die op een of andere manier belast zijn met de uitvoering van een overheidstaak. We komen dan in de sfeer van het openbaar belang en het freies Ermessen van de overheid, waaromtrent vanuit het vennootschapsrecht niet veel valt op te maken. Doch zelfs het belast zijn met een overheidstaak is niet een omstandigheid die bepalend is voor de ontheffing. ${ }^{139} \mathrm{En}$ het is vanuit het vennootschapsrecht bezien niet duidelijk waarom hetgeen voor 'overheidsvennootschappen' op dit punt geldt, niet ook voor de burgers zou kunnen gelden. De hiervoor genoemde motieven van de minister om de ontheffingen te verlenen (maatschappelijke aanvaardbaarheid, etcetera) zijn naar mijn mening evenzeer van toepassing ten aanzien van de activiteiten die de rechtsgenoten ontplooien. Wellicht zou men kunnen stellen dat de wet de bevoorrechte positie van de overheid erkent waar aan overheidsinstanties de mogelijkheid wordt geboden éen of meer commissarissen te benoemen. Ik

\section{5.(...vervolg)}

worden gekozen niet in voldoende mate kan worden tegemoet gekomen. Vaak immers is de kring van personen kwantitatief bezien niet beperkt maar wel feitelijk, omdat het, om verschillende redenen, aannemelijk is dat alleen een klein aantal van de potentiële kandidaten dadwerkelijk in aanmerking komt voor benoeming. In de beschikkingspraktijk van de minister komen deze constellaties regelmatig voor. Zie bijvoorbeeld Beschikkingen d.d. 15 april 1982, De NV 66 (1988), blz. 106 (Elektriciteitsmaatschappij IJsselcentrale); 16 december 1985, De NV 66 (1988). blz. 109 (PLEM II); 8 maart 1988, De NV 67 (1989), blz. 17 (ElectriciteitsMaatschappij IIsselcentrale); 2 juni 1989, De NV 69 (1991), blz. 262 (SEP).

136. Een lijn die Van der Grinten in zijn noot zegt niet te kunnen ontdekken.

137. Beschikking d.d. 8 maart 1988, De NV 67 (1989), blz. 18, (Electriciteits-Maatschappij IJsselcentrale).

138. Beschikking, d.d. 6 maart 1990, De NV 69 (1991), blz. 290 (Provinciale Gelderse Energie-Maatschappii). Zie verder over kwaliteitseisen voor overheidscommissarissen $\$ 16$,III.

139. Vgl. de beschikking inzake De Porceleyne Fles, De NV 66, blz. 31. 
zou echter menen dat dit geen afbreuk doet aan de principiële gelijkheid van overheid en rechtsgenoten met betrekking tot de rechten ex art. 156, omdat in dit artikel, anders dan in art. 158 lid 12, geen bijzondere voorziening voor overheidsinstanties wordt gegeven.

\section{De bezwaargronden van artt. 158/268 lid 6}

De coöptatiebevoegdheid van de structuur-rvc is niet absoluut. Tegen een voorgenomen benoeming kan door de ava en door de bevoegde or bezwaar worden gemaakt. Het bezwaar van deze instanties dient aan de rvc te worden medegedeeld onder opgave van redenen (art. 158 lid 8). Met Van der Grinten ${ }^{140}$ zou ik willen aannemen dat het bezwaar ook zonder motivering rechtsgeldig kan worden ingediend. Voldoende is dat de bezwaarmakende instanties aangeven op welke van de in wet genoemde gronden zij zich baseren. Tijdens het geding kunnen deze instanties feiten en omstandigheden aanvoeren waarop het bezwaar steunt. ${ }^{14 !}$ Het lijkt mij dat het kenbaar maken aan de rvc van de gronden waarop het bezwaar wordt gebaseerd voor de geoorloofdheid ervan geen zin heeft, omdat niet de raad maar de OK daarover dient te oordelen.

Het maken van bezwaar bewerkstelligt dat de rvc niet tot benoeming kan overgaan. Een benoemingsbesluit van de rvc genomen in weerwil van het bezwaar is nietig. Anderzijds volgt uit de wettelijke regeling dat indien tegen het voorstel van de rvc geen bezwaar is ingediend, de raad rechtsgeldig kan benoemen. Het benoemingsbesluit is niet nietig indien naderhand blijkt dat een van de bezwaargronden zich voordoet, bijvoorbeeld dat de benoemde persoon ongeschikt is voor het ambt. Deze omstandigheid kan wel een ontslaggrond opleveren in de zin van art. 161.

De wet noemt drie gronden waarop het bezwaar kan worden gebaseerd (art. 158 lid 6). Deze gronden zijn: het niet naleven van de benoemingsprocedure, de ongeschiktheid van de kandidaat en het ten gevolge van de benoeming niet naar behoren samengesteld zijn van de raad. De eerste grond is bij Wet van 1 juli 1987, Stb. 336, aan de overige gronden toegevoegd. Dit gebeurde bij gelegenheid van de overdracht van de bevoegdheden terzake van de commissarisbenoemingen van de SER aan de OK.

140. Handboek, nr. 286.1.

141. Niet correct lijkt mij dan ook de overweging van de OK in de zaak Nedlloyd 2 (OK 24 september 1992, De NV 70 (1992), blz. 253, r.o. 3.2) dat bepaalde omstandigheden niet vatbaar zijn voor behandeling in het geding omdat zij niet eerder aan de rve kenbaar zijn gemaakt. Datgene wat de OK "bezwaren" noemt zijn mijns inziens niet bezwaren in de zin der wet maar de gronden die de bezwaren dragen. 
Daarmee werd beoogd de competentie in alle kwesties betreffende art. 158 bij één rechterlijke instantie te concentreren. ${ }^{142}$

Het bezwaarrecht is een delicaat mechanisme in de structuurregeling. Daarmee wordt de coöptatiebevoegdheid van de rvc binnen bepaalde grenzen gehouden. Het bezwaarrecht heeft een beperkte strekking omdat het slechts kan worden uitgeoefend op de in de wet genoemde gronden. Men zou het aldus kunnen stellen, dat de bezwaargronden van art. 158 lid 6 de verdeling van bevoegdheden met betrekking tot de benoeming van commissarissen onder de verschillende organen regelen. Hoewel de benoemingsmacht aan de rvc toekomt, hebben ook ava en or middels het bezwaarrecht zeggenschap met betrekking tot de benoeming. Van belang zijn met name de materiële gronden, die kortheidshalve met termen als 'ongeschiktheid' en 'onbehoorlijkheid' kunnen worden omschreven. Het cruciale punt bestaat in de vaststelling van het objectief, dan wel subjectief karakter van die gronden. Immers hoe objectiever de grond is, des te minder beoordelingsvrijheid toekomt aan de bezwaarmakende organen en des te meer benoemingsvrijheid de rvc heeft. En andersom. Indien de gronden in subjectieve zin moeten worden verstaan, zal men moeten aannemen dat ava en or vrij zijn in het bepalen van hetgeen 'ongeschiktheid' en 'onbehoorlijkheid' betekenen. De rvc zal dan een beperktere benoemingsvrijheid hebben.

Duidelijk is in ieder geval dat het bezwaarrecht in het systeem van de wet iets anders is dan een vetorecht. Ava en or stellen niet autonoom vast in hoeverre een van de wettelijke gronden zich voordoet. Een dergelijk autonoom oordeel leent zich ook niet voor rechterlijke toetsing.

Men zou de bezwaargronden, met name die van de ongeschiktheid, enigszins kunnen objectiveren door te stellen dat gebrek aan vertrouwen bij de bezwaarmakende instanties, de kandidaat ongeschikt maakt voor het ambt. Echter, met de zelfstandige benoemingsbevoegdheid van de rvc en de beperkte strekking van de bezwaargronden is moeilijk te rijmen dat het enkel gebrek aan vertrouwen in de kandidaat de benoemingsbevoegdheid van de rvc kan blokkeren. Reeds in de eerste SER-beslissing is bepaald dat dit criterium niet overeenstemt met de wettelijke regeling. ${ }^{143}$

142. Zie over de nadelen van het systeem van verspreide bevoegde instanties de noot van Maeijer onder Hof 's-Gravenhage 24 april 1981, NJ 1983, 5.

143. SER-beslissing d.d. 22 september 1978 (Lanser), de NV 56 (1978), blz. 218 e.v. Gebrek aan vertrouwen levert slechts dan ongeschiktheid op indien "voor het ontbreken van vertrouwen gronden en motieven worden gesteld en bij tegenspraak aannemelijk gemaakt, van zulk een ernst dat de kandidaat in redelijkheid niet in aanmerking behoort te komen voor de benoeming tot commissaris." De geciteerde overweging komt tamelijk dicht in de buurt van een absoluut objectief criterium.

(Wordt vervolgd...) 
Niet veel anders is de situatie betreffende het door Slagter en anderen de lege ferenda voorgestelde criterium "geobjectiveerd gebrek aan vertrouwen". ${ }^{144}$ Als ik het goed zie, ligt het onderscheidend element van het "geobjectiveerd gebrek aan vertrouwen" in het feit dat daarbij de nadruk ligt op het vertrouwen als bezwaargrond en dus op de wil van ava en or. Ten opzichte van het ongeschiktheidscriterium brengt het geobjectiveerd gebrek aan vertrouwen een grotere vrijheid voor laatstgenoemde instanties met zich mee en tevens meer beperkingen aan het oordeel van de rvc. Wat men over dit criterium de iure constituendo ook moge denken, duidelijk lijkt mij dat de versterking van de positie van de bezwaarmakende instanties, waartoe aanvaarding van het vertrouwenscriterium leidt, niet in overeenstemming is met de zelfstandige positie van de rvc in de Structurwet. De autonome beschikking over de commissariële ambten vormt immers de spil van de structuurregeling. ${ }^{145}$

143. (...vervolg)

Daarmee krijgt de rvc een ruime benoemingsvrijheid en wordt het bezwaarrecht van ava en or vrijwel illusoir gemaakt. Immers, onder normale omstandigheden zal de rvc immers geen kandidaat voordragen die niet in redelijkheid voor benoeming in aanmerking komt. In latere SER-beslissingen is dit standpunt afgezwakt, maar steeds is de eis gesteld dat er "voldoende objectieve gronden", of soortgelijke objectiverende omstandigheden, zouden worden aangevoerd. Vgl. over deze evolutie de noot van Van Schilfgaarde bij de Amfas-beslissing, d.d. 21 oktober 1983 in de NV 62 (1984), blz. 111-112. Dit is ook thans het standpunt van de OK: "dat voor dat ontbreken van vertrouwen objectieve gronden moeten worden aangetoond", OK 11 april 1991, NJ 1991, 533 (REGEV), r.0. 4.10.

144. SER-advies d.d. 13 april 1984, 84/06, Advies raden van commissarissen structuurvennootschappen, Uitgaven van de SER 1984, blz. 62. Hierbij doet zich de moeilijkheid voor dat dit criterium niet vrij te pleiten is van een zekere innerlijke tegenstrijdigheid. Immers het is de vraag in hoeverre het gebrek aan vertrouwen geobjectiveerd kan worden omdat vertrouwen per definitie subjectief is, dit is van de persoon afhankelijk. Wellicht zouden argumenten en omstandigheden kunnen worden aangevoerd op grond waarvan een 'normale' of 'redelijke' persoon ergens op zou dienen te vertrouwen. Beslissend is dit allerminst. Bepalend is het persoonlijk oordeel van de persoon die het vertrouwen 'moet' schenken. Door het vertrouwen te objectiveren komt men terecht in de ongeschiktheid als objectief gegeven. Zo bijvoorbeeld de OK in de REGEV-beschikking, r.0. 45, waar de Kamer overweegt dat "een gebrek aan vertrouwen in dit kader nauwelijks iets anders kan betekenen dan de verwachting van ongeschiktheid." Enigszins gechargeerd zou men kunnen zeggen dat de kandidaat ongeschikt is, omdat hij onbetrouwbaar moet worden geacht. Terecht wordt dan ook gesteld dat deze hezwaargrond gedekt wordt door het ongeschiktheidscriterium. SER-advies 84/06, blz. 61; Van Schilfaardo (1984), blz. 2: Van Vliet, WPNR 5754 (1985), blz. 623.

145. Met het oog op "vermindering van de "onaantastbaarheid" van de rve in het structuurmodel stelt Van den Hoek (TVVS 1992, blz. 278) voor het in de tekst besproken criterium als bezwaargrond in te voeren. 
Mijns inziens is de keuze voor een objectieve benadering van de bezwaargronden geboden. De aard van het bezwaarrecht met zijn beperkte gronden en de positie van de rvc in het structuurmodel brengen met zich mee dat, de rvc bij de uitoefening van de benoemingsbevoegdheid, een ruime beoordelingsvrijheid heeft. Om deze reden meen ik dat in geval van twijfel over de gegrondheid van het bezwaar, het oordeel van de rvc dient te prevaleren boven dat van het bezwaarmakend orgaan. ${ }^{146}$ De OK zal het oordeel van de rvc slechts terzijde kunnen stellen indien de ava of de or met kracht van argumenten aantonen dat de kandidaat ongeschikt is, dan wel dat de raad als geheel niet naar behoren zal zijn samengesteld. In dit verband maakt Van Schilfgaarde ${ }^{147}$ een zeker onderscheid tussen de twee gronden waarop het bezwaar kan worden gebaseerd. Volgens deze schrijver is het behoorlijkheidscriterium beter objectiveerbaar dan het ongeschiktheidscriterium omdat het eerste minder subjectieve elementen bevat. Aan dit onderscheid ligt impliciet de stelling ten grondslag dat het gemakkelijker is vast te stellen wat een goede rvc is dan wat een goed commissaris is. Dit lijkt ook mij het geval te zijn. De geschiktheid van een persoon voor een vennootschappelijke functie is rechtens nauwelijks toetsbaar omdat in deze het bevoegde orgaan autonoom is in zijn keuze. ${ }^{148}$ Daarentegen is het goed mogelijk criteria voor de behoorlijkheid van de samenstelling van de raad vast te stellen. Hiervoor heb ik bijvoorbeeld betoogd dat de afwezigheid van vertegenwoordigers van de aandeelhouders in de rvc -althans wanneer de aandeelhouders daar present willen zijn- zich niet verdraagt met het wezen van de vennootschap. Met name in situaties waarin sprake is van een enig aandeelhouder, zoals bij een concern, spreekt het voor zich dat de rvc bezet wordt door mensen die het vertrouwen van moedervennootschap genieten. ${ }^{149}$ Een ander inmiddels vaststaand criterium is dat

146. Anders Van Schilfgaarde, noot onder de SER-beslissing d.d. 26 mei 1982, De NV 60 (1982), blz. 215 (Holec) en (1984), blz. 3-4. Volgens Maeijer, noot onder OK 11 april 1991, NJ 1991, 533 (REGEV), blijkt uit deze beschikking dat de OK het standpunt van Van Schilfgaarde niet volgt. Zie ook de noot van Van der Grinten in De NV 69 (1991), blz. 188.

147. Noot onder SER-beslissing inzake Mobil Oil B.V., de NV 61 (1983), blz. 58-59. Zie ook Van Schilfgaarde (1984), blz. 3.

148. HR 13 februari 1942, NJ 1942, 360 (Baus/De Koedoe).

149. Vgl. hieromtrent de SER-beslissing inzake Cyanamid B.V., De NV 61 (1983), blz. 233 e.v., en de beschikking van de OK d.d. 2 februari 1989, NJ 1990, 86 (Kodak). Terecht oordeelt Maeijer in een noot onder laatstgenoemde beschikking dat het concern geen bijzonder belang aannemelijk hoeft te maken, opdat een meerderheid van concerngebonden commissarissen in de rvc van een structuurdochter toelaatbaar wordt geacht. De hoedanigheid van dochtervennootschap is daarvoor een genoegzame rechtvaardiging. In gelijke zin Slagter, TVVS 1989, blz.

(Wordt vervolgd...) 
minstens één commissaris kennis heeft van de Nederlandse sociaaleconomische verhoudingen. ${ }^{150}$

Ik zou tot slot nog aandacht willen besteden aan de mogelijkheid de bezwaargronden contractueel uit te breiden.

Deze problematiek is door de SER behandeld in de ODS-zaak. ${ }^{151}$ De SER verwerpt de stelling dat een contractuele uitbreiding van de bezwaargronden zou leiden tot een uitbreiding van zijn bevoegdheid om kennis te nemen van de contractuele bezwaren. Terecht oordeelt de SER dat de wettelijke bezwaargronden in deze zin limitatief zijn opgesomd. Mede op grond van deze overweging van de SER achten sommige schrijvers een contractuele uitbreiding van de gronden geoorloofd mits de bevoegdheid van de SER (thans: de OK) terzake van de wettelijke gronden onaangetast blijft. ${ }^{152}$ Het komt mij echter voor dat de wettelijke gronden in het systeem van de wet meer beogen dan het bepalen van de rechterlijke competentie en dat contractuele uitbreiding van de wettelijke gronden niet geoorloofd is.

De limitering van bezwaargronden en de toekenning aan een gespecialiseerde instantie van de competentie om over deze aangelegenheden te oordelen beogen, zoals hiervoor is gesteld, een zorgvuldig evenwicht tot stand te brengen tussen de bevoegdheden van de verschillende organen met betrekking tot de benoeming van commissarissen. Op deze dwingende verdeling van bevoegdheden berust het verbod om op dit punt over de vennootschappelijke bevoegdheden te disponeren.

149. (...vervolg)

203; Brenninkmeijer, Praktijkboek Commissarissen, nr. III.25. Anders Van Schilfgaarde, De NV 67 (1989), blz. 122. Zie ook de twee beschikkingen inzake Nedlloyd d.d. 24 september 1992, De NV 70 (1992), blz. 251. In zijn noot onder de tweede beschikking merkt Van der Grinten naar aanleiding van een overweging van de OK op: "Naar mijn mening kan die eis [van 'aandeelhoudersachtergrond"] zeker in zijn algemeenheid niet worden gesteld. Het is niet een eis van goede samenstelling van de raad van commissarissen dat tenminste eén commissaris een aandeelhoudersachtergrond heeft." Zoals gezegd, meen ik dat indien de aandeelhouders dit wensen zulks wel als een eis van behoorlijke samenstelling geldt.

150. SER-beslissing d.d. 16 maart 1979 (Standard Electric), De NV 57 (1979), blz. 94 e.v. en inzake Mobil Oil B.V., De NV 61 (1983), blz. 56 e.v.

151. Beslissing d.d. 20 december 1985, De NV 64 (1986), blz. 118 e.v. Overwogen werd: "Daargelaten of de clausule rechtsgeldig is gezien het dwingend rechtelijke karakter van het structuurregime dat voor ODS geldt, het dagelijks bestuur is gehouden de bezwaren van de a.v.a. uitsluitend te toetsen aan de in de wet genoemde gronden. De bevoegdheid van het dagelijks bestuur kan niet door overeenkomsten worden verruimd of beperkt; de bezwaargronden zijn in art. 268 lid 6 limitatief opgesomd."

152. In deze zin Slagter, TVVS 1986, blz. 124; Van den Hoek (1991), blz. 92. 
Daar komt bij dat het niet is in te zien hoe de bezwaargronden zouden kunnen worden uitgebreid. Wat commissarissen betreft heb ik reeds gesteld dat zij, handelend als commissarissen, onderworpen zijn aan de wettelijke en statutaire regeling. De niet nader gemotiveerde stelling dat commissarissen bevoegd zijn om de gronden van art. 158 uit te breiden lijkt mij in strijd met art. 25. Ook het karakter van de wettelijke bezwaargronden pleit tegen de mogelijkeid van contractuele uitbreiding. Deze gronden zijn dermate ruim dat zij de gehele rechtspositie van de afzonderlijke commissarissen en van de raad als orgaan omvatten, waardoor aangenomen moet worden dat de instantie, die krachtens de wet bevoegd is over benoemingen van commissarissen te oordelen, met betrekking tot de gehele rechtspositie van zowel de commissarissen als de raad exclusief bevoegd is. ${ }^{153}$

Een andere kwestie is dat aandeelhouders zich persoonlijk binden terzake van de uitoefening van het bezwaarrecht. In dit geval disponeren aandeelhouders over het eigen stemrecht. Een dergelijke dispositie is niet ongeoorloofd. Zo kunnen zij bijvoorbeeld naar eigen inzicht contractueel nader bepalen dat een bepaalde kwaliteit van de commissaris hem ongeschikt maakt voor de functie. Ook kunnen zij afspreken wat zij onder een behoorlijke samenstelling zullen verstaan. Dat dergelijke afspraken aan de bevoegdheid van de rvc niet afdoen, behoeft geen nader betoog.

\section{§16. Bijzondere gevallen}

Wettelijk is de rechtspositie van alle leden van de rvc gelijk. Krachtens statuten, reglement of besluit van het bevoegde orgaan kunnen echter aan één of meer commissarissen bijzondere bevoegdheden worden toegekend. Voorts kunnen bepaalde omstandigheden van belang zijn voor de taakvervulling van de individuele commissarissen. Commissarissen kunnen bijvoorbeeld een speciale binding hebben met het benoemend orgaan. Deze

153. Van den Hoek (1991), blz. 92, verwijst naar een arbitraal vonnis waarin werd bepaald dat een zeker benoemingsbesluit in strijd was met de jegens de aandeelhoudster in acht te nemen goede trouw. Hoe de arbiters tot de conclusie komen dat het besluit in strijd is met de goede trouw is niet bekend. Het is echter de vraag hoe bij een structuurvennootschap "de goede trouw" met zich mee kan brengen dat het benoemingsbesluit onrechtmatig is jegens de aandeelhoudster. Deze onrechtmatigheid kan in onze wet alleen worden gebaseerd op het feit dat de rvc niet naar behoren is samengesteld. Doch het oordeel over de behoorlijkheid van de samenstelling is aan de OK voorbehouden. Met betrekking tot de geldigheid van het besluit op zich is het arbitrale oordeel zonder betekenis omdat in deze slechts de burgerlijke rechter bevoegd is (art. 15 lid 3 resp. 158 lid 9). 
en andere omstandigheden bewerkstelligen dat, ondanks het wettelijke uitgangspunt van gelijkheid in rechtspositie, verschillende figuren kunnen worden onderscheiden.

\section{President-commissaris}

De president-commissaris is de voorzitter van de rvc. Het voorzitterschap houdt de macht in om het orgaan te leiden. Deze leidingsmacht heeft primair een interne betekenis. De president-commissaris dient ervoor te zorgen dat de rvc naar behoren functioneert, dat de raad met de nodige frequentie bijeenkomt en dat de individuele leden hun taak behoorlijk vervullen. Daarnaast geldt dat hij in het externe verkeer het beeld van de vennootschap in zekere mate bepaalt. ${ }^{154}$ Dit aspect van de functie kan van invloed zijn op de rechtspositie van de president-commissaris. Het feit dat hij primus inter pares is betekent dat hij meer dan andere commissarissen dient te zorgen voor de gang van zaken binnen de raad. Met deze verantwoordelijkheid kan een grotere aansprakelijkheid gepaard gaan. Het voorzitterschap brengt een zekere verzwaring van het commissariaat met zich mee. ${ }^{155}$

De wet bevat geen bijzondere regeling met betrekking tot het voorzitterschap van de rvc. De positie van de president-commissaris zal veelal in de statuten of in het reglement van de rvc worden geregeld. De organen die zeggenschap hebben over de inhoud van de statuten en van het rvc-reglement bepalen dan ook de positie van de president. Op dit punt dient onderscheid te worden gemaakt tussen het gewone- en het structuurmodel.

$\mathrm{Bij}$ gewone vennootschappen beslist de algemene vergadering of er een rvc zal zijn. $\mathrm{Zij}$ beschikt ook over de commissariële ambten. ${ }^{156}$ In dit

154. In gelijke zin Van der Burg, TVVS 1985, blz. 68. Zie voorts over de presidentcommissaris Glasz (1992), blz. 137 e.v.

155. Het representatieve karakter van het voorzitterschap en de feitelijke gang van zaken binnen de vennootschap zouden er toe kunnen leiden dat de toezichthoudende taak van de rve bij zijn president wordt geconcentreerd. Deze taak is in het systeem van de wet een collegiale, waardoor alle commissarissen een principieel gelijke positie hebben. Terecht waarschuwt Van der Burg (TVVS 1985, blz. 69) in dit verband dat een monopolisering van het recht op informatie in strijd met de wet zou zijn. Het informeren omtrent de eigen werkzaamheden aan de andere leden lijkt mij het middel bij uitstek om monopolisering van de toezichthoudende taak bij de president tegen te gaan.

156. Ook wanneer benoeming, schorsing en ontslag van een deel van de rve door een derde geschiedt (artt. 143 en 144) heeft de ava in laatste instantie zeggenschap over de rechtspositie van deze commissarissen omdat de rechten van de derde statutair zijn verankerd. 
systeem past dat zij ook zeggenschap heeft over de invulling van het voorzitterschap. Twijfel kan bestaan over de vraag of op dit punt aan de prioriteit zeggenschap kan worden gegeven. Hiervoor is verdedigd ( $\$ 5$ ) dat toekenning van zeggenschap aan prioriteitsaandeelhouders voor wat betreft de dwingende bevoegdheidssfeer van de rvc ongeoorloofd is. Het aanwijzen van de persoon die de rvc zal voorzitten is in het gewone model niet een aangelegenheid die de bevoegdhedenverdeling raakt, waardoor het mij geoorloofd lijkt dat de benoeming van de president door de prioriteit geschiedt indien, de bevoegdheid van de prioriteit op de statuten berust. ${ }^{157}$ Ook de schorsing en het ontslag als president, dus niet als commissaris, kan door de prioriteit geschieden.

Een meer stringent regime geldt voor structuurvennootschappen. In het structuurmodel heeft de algemene vergadering geen macht over het ambt van de commissaris. De rvc vervult zijn taak zonder onderwerping aan de zeggenschap van de algemene vergadering. In deze opzet past dat de gang van zaken binnen de rvc niet in de statuten wordt geregeld, doch dat de rvc zelf zijn functioneren regelt. Het is eveneens passend dat de bevoegdheid tot anwijzing van de president-commissaris door de rvc zelf wordt uitgeoefend. Dit standpunt wordt door Van der Grinten gedeeld ${ }^{158}$, zij het dat hij een afwijkend regime voor overheidsvennootschappen geoorloofd acht. Naar zijn oordeel is het "in zulk een vennootschap aanvaardbaar, dat de statuten -dus de aandeelhouders- bepalen dat een door de overheid benoemde commissaris voorzitter zal zijn. Aan de statuten kan vrijheid worden gelaten het voorzitterschap te koppelen aan de benoeming door een bepaalde instantie." 159 Deze schrijver geeft zelf aan dat een dergelijke statutaire aanwijzing volgens de minister een ad hoc beschikking op grond van art. 156 vereist. Het standpunt van Van der Grinten wordt niet nader gemotiveerd. Twee verklaringen zouden voor zijn standpunt kunnen worden gegeven. De bijzondere positie van de overheid zou kunnen worden gebaseerd op het feit dat de overheid enig aandeelhoudster is, en dat zulks de bevoegdheid met zich meebrengt de president aan te wijzen. Dit lijkt mij echter een onjuiste argumentatie te zijn, omdat de bijzondere rechten die art. 158 lid 12 aan de overheid toekent los staan van het aandeelhouderschap. Ook bij structuurvennootschappen waarin de overheid in het geheel niet participeert is het mogelijk dat de statuten aan de overheid de bevoegd-

157. Zo ook Handboek, nr. 281.

158. Handboek, nr. 281.

159. De NV 69 (1991), blz. 265, noot onder de beschikking d.d. 24 oktober 1989. Zie ook in gelijke zin zijn noot onder de beschikking d.d. 23 maart 1987, De NV 65 (1987), blz. 252. 
heid geven commissarissen te benoemen. ${ }^{160}$ Een tweede verklaring zou kunnen worden gevonden in art. 158 lid 12 zelf. Verdedigd zou kunnen worden dat de bevoegdheid om de president-commissaris aan te wijzen aan het benoemingsrecht van de overheid verbonden is. Dit is het standpunt dat Van der Grinten inneemt terzake van benoeming van een gedelegeerde commissaris bij structuurvennootschappen door de overheid. ${ }^{161}$ Met Westbroek $^{162}$ ben ik echter van mening dat deze visie afbreuk doet aan de zelfstandige uitoefening van bevoegdheden door een structuur-rvc en daarom in strijd is met de wet. De benoemingsbevoegdheid van het twaalfde lid van art. 158 reikt niet verder dan hetgeen in het artikel is bepaald, en daarin wordt over de bevoegdheid tot aanwijzing van de voorzitter van de raad, hoe wenselijk en aanvaardbaar zij voor de overheid ook moge zijn, niet gesproken. Het benoemingsrecht van de overheid doet geen afbreuk aan het beginsel van gelijke rechtspositie van de commissarissen; voor een afwijking van dit beginsel is een uitdrukkelijke bepaling noodzakelijk.

Dat de benoemingsbevoegdheid van de overheid niet de macht impliceert om de president aan te wijzen kan worden geillustreerd, door deze bevoegdheid te vergelijken met die tot benoeming van een gedelegeerde commissaris. In het structuurmodel zijn de extra bevoegdheden van de gedelegeerde commissaris door de raad van commissarissen gedelegeerd. Ook wanneer de ava of de overheid het benoemend orgaan is, houdt de benoemingsbevoegdheid niet in dat zij toezichthoudende bevoegdheden aan de gedelegeerde commissaris kunnen toekennen. Deze delegatie is bij een structuurvennootschap aan de rvc voorbehouden. Mutatis mutandis dient dit beginsel ook te gelden voor de aanwijzing van de president in het structurmodel. Voor de uitoefening van haar vennootschapppelijke bevoegdheden is de overheid evenzeer gebonden aan de vennootschappelijke orde -wet en statuten- als de andere organen. Afwijking van deze orde is slechts mogelijk krachtens beschikking van de minister op grond van art. 156.

De hoedanigheid van president-commissaris betekent rechtens meer dan het voeren van een titel. Aan het ambt van president-commissaris dienen bepaalde bevoegdheden verbonden te zijn die de president in staat stellen leiding te geven aan het college van commissarissen. De inhoud van het voorzitterschap kan mede worden bepaald door het gebruik. De gang van zaken binnen de vennootschap kan medebrengen dat aan de president-

160. Zie in deze zin ook de Nota Inzake Commissarissen van Overheidswege, van het Ministerie van Financiën, d.d. 28 maart 1991, m.n. blz. 40, alwaar ook enkele voorbeelden worden gegeven. Zie ook Handboek, nr. 291.

161. Handboek, nr. 281.1.

162. De NV 65 (1987), blz. 181. 
commissaris feitelijk meer bevoegdheden worden toegekend dan in zijn functieomschrijving wordt bepaald.

\section{Gedelegeerde commissaris}

De gedelegeerde commissaris is een vennootschapsorgaan voor zover hem bepaalde bevoegdheden zijn toegekend. Deze bevoegdheden vormen het bepalende element van zijn rechtspositie. De gedelegeerde commissaris is ook lid van de raad van commissarissen omdat zijn bevoegdheden zich richten naar de vervulling van de toezichthoudende taak, die uitsluitend aan de rvc toekomt. Creatie van het orgaan en benoeming dienen te worden onderscheiden. Hoewel zulks niet noodzakelijk is, zal in de regel de creatie van het orgaan van gedelegeerde commissaris aan de benoeming van de betrokken commissaris voorafgaan. Op verschillende manieren kan het orgaan tot stand komen.

In navolging van Kamphuisen ${ }^{163}$ kan men in dit opzicht onderscheid maken tussen wat hij noemt gedelegeerde met (uitsluitend) afgeleide bevoegdheid en gedelegeerde met (ook) eigen bevoegdheid. Eerstgenoemd orgaan komt tot stand door middel van delegatie van bevoegdheden die aan de raad toekomen. De delegatie berust op een besluit van de rvc, zonder dat veor het besluit een statutaire grondslag noodzakelijk is. ${ }^{164}$ In het tweede geval kan het orgaan worden gecreëerd door attributie van bevoegdheid. Deze bevoegdheid wordt dan ontleend aan een ad hoc besluit van de algemene vergadering of an een statutaire bepaling. Ik meen dat deze wijze van totstandkoming van het orgaan bij structuurvennootschappen slechts mogelijk is op grond van een statutaire bepaling (art. 140 lid 3).

Voor de benoeming als gedelegeerde commissaris is het noodzakelijk dat betrokkene commissaris is. Evenals bij de president-commissaris het geval is, meen ik dat de bevoegdheid tot benoeming van de commissaris niet ea ipsa de bevoegdheid inhoudt om de gedelegeerde in deze hoedanigheid te benoemen. Dit is een bevoegdheid die toekomt aan het orgaan dat de beschikking heeft over de commissariële ambten, dat wil zeggen de ava in het gewone model en de rvc in het structuurmodel. ${ }^{165}$ De benoeming

163. De NV 34 (1956-57), biz. 42.

164. In gelijke zin Handboek, nr. 281.1.

165. Bij een structuurvennootschap is het mogelijk dat een overheidsinstantie bevoegd is alle commissarissen te benoemen. Mogelijk is voorts dat alle commissarissen door de ava worden benoemd indien de minister op grond van art. 156 op dit punt ontheffing verleent. Ook in deze gevallen zou ik echter willen aannemen dat de benoemingshevoegdheid niet de competentie met zich mee brengt om de gedele-

(Wordt vervolgd...) 
als gedelegeerde commissaris kan samenvallen met de creatie van het orgaan. De bevoegde instantie delegeert of attribueert de bevoegdheden in kwestie en benoemt de persoon die met de uitoefening ervan belast zal zijn.

Een omstreden kwestie betreft de vaststelling van de te delegeren bevoegdheden. ${ }^{166}$ De Departementale Richtlijnen ( $\S 6$ ) schrijven voor dat, indien de statuten het orgaan van gedelegeerde commissaris kennen, zijn speciale taak moet worden vermeld. Deze taak mag geen afbreuk doen aan de wettelijke taak en bevoegdheden, welke aan de raad van commissarissen toekomen. Voorts wordt bepaald dat geen andere bevoegdheden, dan die de rvc reeds heeft, mogen worden toegekend.

Dat aan een lid van een wettelijk orgaan geen andere taken mogen worden toegekend dan die welke de wet voorschrijft spreekt vanzelf. Deze gelijkheid in taakstelling stelt de opsteller van de statuten evenwel voor de moeilijkheid om de taak van de gedelegeerde commissaris te omschrijven. Met Westbroek ${ }^{167}$ zou ik willen aannemen dat volstaan kan worden met een algemene omschrijving in de trant van: "De gedelegeerd commissaris is belast met het dagelijkse toezicht op de directie." Tegen dit soort omschrijvingen voert Kamphuisen aan, dat er "principieel geen grens te trekken is voor het toezicht op de directie dat krachtens het wezen van het commissarisschap aan commissarissen toekomt. ${ }^{168}$ Met andere woorden, het toezicht dat de rvc dient uit te oefenen zou geen gradaties kennen, zodat ieder toezicht, al of niet dagelijks, tot de taak van de raad behoort. Dit lijkt mij zonder meer juist, doch laat onverlet dat een of meer leden van de raad in het bijzonder belast worden met deze toezichthoudende taak en dus, met de uitoefening van de daarmee samenhangende bevoegdheden. Dit lid is de gedelegeerde commissaris.

Voor wat betreft de te delegeren bevoegdheden is het departementale standpunt dat de taak van de gedelegeerde commissaris geen bevoegdheden mag inhouden die niet reeds aan de rvc zelf toekomen. In zijn algemeenheid lijkt mij dit standpunt onjuist. Indien de bevoegdheden van de gedeleerde commissaris op attributie berusten, kunnen de statuten aan de

\section{5.(...vervolg)}

geerde commissaris te benoemen. Deze benoeming behoort naar mijn mening tot de competentie van de rve omdat zij onder de uitoefening van de toezichthoudende taak valt.

166. Om recht te doen aan de naam van gedelegeerde commissaris zal ik in het vervolg, tenzij anders blijkt, van 'delegatie' spreken ook wanneer de toekenning van bevoegdheden op attributie berust.

167. Rechtspersonen, commentaar op de Departementale Richtlijnen, $\$ 6$, aant. 8 . Evenzo Handboek, nr. 281.1.

168. (1956), blz. 43. 
gedelegeerde bevoegdheden toekennen die buiten de bevoegdheidssfeer van de rvc vallen. In het Handboek worden als voorbeelden genoemd: de vaststelling van het salaris van bestuurders en de bepaling van het aantal leden van het bestuur of van de raad van commissarissen. ${ }^{169}$ Hieraan kan met name de goedkeuring van bepaalde bestuursbesluiten worden toegevoegd. Indien de bevoegdheid van de gedelegeerde op delegatie door de raad berust is het duidelijk dat nemo dat quod non habet.

De begrenzing van de bevoegdheidssfeer van de gedelegeerde commissaris is te vinden in zijn taak. Zo kunnen hem bijvoorbeeld geen bestuursbevoegdheden worden toegekend. Kamphuisen oordeelt hier anders over. ${ }^{170}$ Deze schrijver aanvaardt de onverenigbaarheid van de bestuursen de toezichthoudende functies en dus dat de gedelegeerde commissaris niet tevens bestuurder kan zijn. Met een beroep op art. 52a WvK (het huidige art. 151) verdedigt Kamphuisen echter dat de gedelegeerde commissaris bestuursbevoegdheden kan uitoefenen zonder daardoor bestuurder te worden, zulks omdat de incidentele bestuurder geen bestuurder in de zin der wet is. Bestuurder is slechts "iemand, die, alleen of met collega's, met de algehele leiding der vennootschap is belast," terwijl iemand die "zonder zelf volledig bestuurder te zijn, voor een bepaalde tijd of incidenteel bestuurdaden verricht, te dien aanzien als bestuurder wordt aangemerkt." ${ }^{171}$ Uit hetgeen hiervoor $(\S 3)$ is betoogd met betrekking tot het verrichten van bestuursdaden volgt dat ik deze visie niet deel. Of iemand, om in de termen van Kamphuisen te spreken, volledige dan wel gedeeltelijke bestuurder is, is i.c. irrelevant. Van belang is niet het bijvoeglijke- maar het zelfstandige naamwoord. Iemand die volledig of gedeeltelijk bestuurt kan niet tevens toezicht houden. De onverenigbaarheid van de functies staat geen gradaties toe. Iets anders is dat, in een concreet geval, de gedelegeerde commissaris daden van bestuur verricht in de zin van art. 151 . Hij zal in dit opzicht als bestuurder worden aangemerkt, hoewel hij als commissaris werd benoemd.

Een andere begrenzing van de bevoegdheidssfeer van de gedelegeerde kan worden gevonden in de taakvervulling van de raad. In het systeem van de wet komt de toezichthoudende taak toe aan het college van commissarissen en niet aan één of meer van zijn leden. De delegatie kan er niet toe leiden dat de uitoefening van de toezichthoudende taak, door het college of door de afzonderlijke commissarissen, belemmerd wordt. Zo lijkt mij ongeoorloofd dat aan de gedelegeerde commissaris de bevoegdheid zou worden toegekend om informatie van het bestuur te ontvangen en te

169. Bij structuurvennootschappen zullen deze bevoegdheden op delegatie door de rvc dienen te berusten.

170. (1956), blz. 45.

171. Blz. 44, curs. ook in het origineel. 
bepalen op welke informatie de overige commissarissen recht hebben.

De vraag rijst of de gedelegeerde commissaris bevoegd is om zijn bevoegdheden te delegeren. Tegen de mogelijkheid van subdelegatie pleit het persoonlijke karakter van het gedelegeerde commissariaat. Met dit karakter is het niet goed verenigbaar dat de gedelegeerde commissaris de uitoefening van zijn bevoegdheden zonder beperkingen aan een ander zou overlaten. Anderzijds kan de mogelijkheid van subdelegatie niet in haar algemeenheid worden afgewezen. Ik zou willen aannemen dat de toelaatbaarheid van subdelegatie per geval zal moeten worden beoordeeld. Subdelegatie is mijns inziens wel toelaatbaar indien zulks bij de creatie van het orgaan of bij de benoeming van de gedelegeerde commissaris uitdrukkelijk is bepaald. De bevoegdheidssfeer van de gedelegeerde commissaris, die bij wijze van subdelegatie is benoemd, wordt door het subdelegatiebesluit bepaald. De persoon die op grond van subdelegatie is benoemd, is onderworpen aan hetzelfde rechtsregime als de gedelegeerde commissaris.

Gesteld is dat de taak van de gedelegeerde commissaris doorgaans bestaat uit het houden van het dagelijkse toezicht op de directie. Het is mogelijk dat de facto deze taak door de president-commissaris wordt vervuld. Het voorzitterschap van de raad, welke bevoegdheid de hoedanigheid van president-commissaris bepaalt, kan met zich mee brengen dat de president een intensiever toezicht uitoefent dan de andere commissarissen. Dit betekent mijns inziens niet dat de president-commissaris dan tevens gedelegeerde commissaris is. Hoewel beide functies door eenzelfde persoon kunnen worden vervuld, zou ik als uigangspunt willen nemen dat, voor het bestaan van de functie van gedelegeerde commissaris, nodig is dat het orgaan als zodanig is gecreëerd. Dit houdt de toekenning in van bepaalde bevoegdheden aan een commissaris. Zonder deze toekenning kan niemand als gedelegeerde commissaris handelen. Aan de andere kant is het niet ondenkbaar dat de rvc stilzwijgend aan een commissaris bepaalde controlerende taken opdraagt. Deze commissaris kan een gedelegeerde commissaris zijn. Hetgeen van belang kan zijn voor de vaststelling van de verantwoordelijkheid en mogelijke aansprakelijkheid van betrokkene.

\section{Overheidscommissaris}

Als overheidscommissaris wordt beschouwd de commissaris die van overheidswege is benoemd. Benoeming door de overheid is zowel mogelijk bij gewone- als bij structuurvennootschappen, waarbij in beide gevallen het benoemingsrecht op een statutaire bepaling berust. Bij een gewone vennootschap geschiedt de benoeming op grond van art. 143. In dit geval geldt de 
beperking dat de overheid niet meer dan eén derde van het aantal leden van de rvc kan benoemen. Bij structuurvennootschappen vindt de benoemingsbevoegdheid van de overheid haar grondslag in art. 158 lid 12. Hier geldt echter geen beperking betreffende het aantal te benoemen commissarissen. Statutair zou kunnen worden bepaald dat de gehele rve door de overheid dient te worden benoemd. ${ }^{172}$ Van een overheidscommissaris zou ook kunnen worden gesproken wanneer betrokkene wordt benoemd door de algemene vergadering van aandeelhouders van een vennootschap waarin de overheid een belangrijke kapitaalparticipatie bezit. De overheid handelt dan niet op grond van een bijzonder recht maar krachtens haar aandeelhouderschap.

De wet bevat geen bijzondere normen voor de overheidscommissaris. Hij is dan ook onderworpen aan het algemene rechtsregime dat voor elke commissaris geldt. Het feit dat hij door de overheid wordt benoemd doet aan deze principiële gelijkheid in rechtspositie niets af. Specifiek voor de overheidscommissaris is zijn verhouding tot de overheid. De overheidscommissaris vertegenwoordigt het belang van de overheid bij de betrokken vennootschap. De Nota Overheidscommissarissen noemt drie factoren die kunnen leiden tot bijzondere betrokkenheid van de overheid bij de vennootschap in kwestie. Deze factoren zijn: de nauwe relatie tussen het overheidsbeleid en het werkgebied van de onderneming; substantieel aandeelhouderschap en de financiële betrokkenheid. ${ }^{173}$ Strikt genomen is slechts de eerste omstandigheid aan de overheid(scommissaris) eigen. Wat de andere twee omstandigheden betreft valt -vanuit het vennootschapsrecht bezien- geen onderscheid te maken tussen de overheid en andere kapitaalverschaffers. In zoverre bestaat geen verschil tussen de overheidscommissarissen en andere commissarissen die geïdentificeerd kunnen worden met een bepaald belang dat bij de vennootschap is betrokken. Men denke aan de familiecommissaris, de bankcommissaris of de werknemerscommissaris. Naar het mij voorkomt betreft de problematiek van de overheidscommissaris hoofdzakelijk zijn taakvervulling. Alvorens daar nader op in te gaan zou ik echter iets willen opmerken over het standpunt van de minister inzake het stellen van kwaliteitseisen voor overheidscommissarissen bij structuurvennootschappen.

172. Hoewel bij enkele vennootschappen in de benoeming van de gehele raad door de overheid voorzien is, is het huidige beleid Jat, zelfs bij vennootschappen waarin de overheid in belangrijke mate participeert, slechts een minderheid van de rvc uit overheidscommissarissen bestaat. Concrete gegevens hieromtrent vindt men in de Nota Inzake Commissarissen van Overheidswege, Ministerie van Financiẻn, Directie Financieringen, d.d. 28 maart 1991 (hierna 'Nota Overheidscommissaris$s e n ')$.

173. Blz. 13. 
Hoewel, zoals hiervoor is opgemerkt, op dit punt niet van een consistente beleidslijn kan worden gesproken, lijkt het standpunt van de minister het volgende te zijn. Indien de benoeming door een overheidsinstantie in de hoedanigheid van aandeelhoudster geschiedt, kunnen kwaliteitseisen slechts worden gesteld voor de kleinst mogelijke meerderheid van het aantal commissarissen. ${ }^{174}$ Indien echter de benoeming door de overheidsinstantie als zodanig plaatsvindt, acht de minister kwaliteitseisen thans ontoelaatbaar. ${ }^{175}$ Waarom in het ene geval kwaliteitseisen wel toelaatbaar zijn en in het andere niet, is "voor de onbevangen beoordelaar niet te begrijpen." ${ }^{176}$ De minister verklaart zijn weerstand tegen kwaliteitseisen bij benoeming door de overheid q.q. met een beroep op "gewijzigde maatschappelijke opvattingen." Vanuit het vennootschapsrecht bezien snijdt deze verklaring geen hout. Het is niet in te zien waarom het feit, dat de benoemingsbevoegdheid van de overheid niet op het aandeelhouderschap berust maar op een bijzonder recht, tot gevolg zou moeten hebben dat de benoemingsbevoegdheid van het bevoegde orgaan niet zou kunnen worden beperkt. Wellicht zou hiervoor als verklaring kunnen worden gegeven dat het handelen van de overheid q.q., hoewel gebaseerd op een bevoegdheid van vennootschapsrechtelijke aard, niet met privaatrechtelijke middelen zoals statutaire kwaliteitseisen beperkt kan worden. Hoe dit ook zij, vanuit vennootschapsrechtelijk oogpunt bestaat geen bezwaar tegen een dergelijke beperking. Deze beperking kan ook wenselijk zijn voor mede-aandeelhouders omdat zij in dat geval via de statutaire eisen de benoemingsbevoegdheid van de overheid enigszins kunnen beïnvloeden.

Keren we thans terug naar de rechtspositie van de overheidscommissaris. Het oordeel over deze positie wordt bepaald door het standpunt dat men inneemt aangaande de problematiek van het vennootschappelijk belang. In de woorden van Honée: "De auteurs die zich in kritische zin uitlaten over de ambivalente rol van de overheidscommissaris doen dit op grond van de tegenstelling die zij zien tussen het overheidsbelang en het vennootschappelijke belang. " 177 Van een dergelijke tegenstelling behoeft geen sprake te zijn. Indien de overheid besluit door middel van een NV of BV een bepaalde activiteit te ontplooien, dan geldt voor de overheid hetzelfde als voor elke burger. Ook de overheid kan haar eigen belang met vennootschaps-

174. Beschikkingen d.d. 20 juni 1986, De NV 64 (1986), blz. 177 (Limagas) en d.d. 2 februari 1990. De NV 69 (1991), blz. 29 (Waterleiding Maatschappij Gelderland). Zie de noot van Van der Grinten onder beide beschikkingen.

175. Beschikking d.d. 6 maart 1990, De NV 69 (1991), blz. 290 (Provinciale Gelderse Energie-Maatschappij).

176. Aldus Van der Grinten, De NV 69 (1991), blz. 291.

177. (1984), blz. 105. Zie de door Honée genoemde auteurs voor nadere referenties. 
rechtelijke middelen trachten te realiseren ${ }^{178}$ Aangezien de vennootschap het overheidsbelang dient zullen alle commissarissen, door het vennootschappelijk belang te dienen, ook het overheidsbelang dienen. Voor de overheidscommissaris is dit mijns inziens principieel niet anders. Anders dan hetgeen regelmatig in de literatuur wordt gesteld zal de tegenstelling tussen vennootschapsbelang en overheidsbelang zich in de regel niet voordoen. ${ }^{179}$ Dit leidt tot de conclusie dat, op dezelfde manier als de rechtspositie van de overheidscommissaris gelijk is aan die van de andere commissarissen, zijn taakvervulling aan geen andere norm, dan die van het vennootschappelijk belang, dient te worden getoetst. Dit belang staat echter niet los van, maar wordt juist bepaald door het overheidsbelang. ${ }^{180}$

Dit brengt ons tot een andere omstreden kwestie of, anders gezegd, tot een ander aspect van dezelfde kwestie. Het betreft hier de verhouding tussen de normen van het vennootschapsrecht en van het publiekrecht. Deze verhouding dient te worden geanalyseerd omdat de persoon die het ambt van overheidscommissaris bekleedt onderworpen kan zijn aan aan de twee rechtsordes. Enerzijds is hij als commissaris lid van een vennootschapsorgaan en als zodanig onderworpen aan de vennootschappelijke orde, anderzijds is hij daarnaast mogelijk ook als ambtenaar onderworpen aan een gezagsverhouding van publiekrechtelijke aard. De problematiek heeft zich voorgedaan bij de benoeming van een overheidscommissaris bij de N.V. Aandelenbezit Streekvervoer. ${ }^{181}$ I.c. had de verantwoordelijke minister bepaalde politieke afspraken gemaakt met betrekking tot de benoe-

178. Mijns inziens zeer terecht spreekt Honée (1984), blz. 114, over het "instrumenteel karakter" van de overheidsvennootschappen. Met zekere beperkingen wordt het instrumenteel karakter van overheidsvennootschappen eveneens aanvaard door Glasz, NJB 1991, blz. 1543. Dit standpunt van Honée is echter moeilijk te rijmen met zijn institutioneel betoog op blz. 14 van zijn inaugurele rede ("De Regeringswaarnemer en de Vennootschappelijke Orde", 1983), waar hij onder andere stelt dat de vennootschap "een instituut [is] en als zodanig, dus onafhankelijk van haar aandeelhouders, gericht op continuiteit van het door haar gefinancierde en geleide ondernemingsverband. Haar bestaansgrond vindt zij in de economische activiteiten die van haar uitgaan." De "gerichtheid" van het instituut wordt mijns inziens niet door het instituut zelf bepaald maar door degenen die zeggenschap hebben in de rechtspersoon. Haar bestaansgrond vindt de vennootschap voorts in de wil van de oprichters/aandeelhouders die haar tot stand hebben gebracht en haar in stand houden.

179. Vgl. echter Van der Burg, WPNR 5371 (1976), blz. 759, WPNR 5798 (1985), blz. 695, en TVVS 1989, blz. 41; Glasz (1991), blz. 1544.

180. Dit wordt kennelijk ook zo door de overheid begrepen. "Het algemeen belang waaruit aldus de bevoegdheid van de overheidsinstantie tot benoeming voortvloeit kan niet gezien worden als tegengesteld aan het eigen belang van de betrokken vennootschap." Nota Overheidscommissarissen, blz. 14. Curs. ook in het origineel.

181. SER-beslissing d.d. 11 april 1985, De NV 63 (1985), blz. 144. 
ming van commissarissen bij deze structuurvennootschap. De geldigheid van een uit deze afspraken resulterende benoeming wordt door de ondernemingsraden van de vennootschap in twijfel getrokken omdat aan de benoemingsprocedure van art. 158 afbreuk zou worden gedaan. Het geval is illustratief voor de verhouding tussen vennootschapsrecht en publiekrecht.

In zijn noot onder de aangehaalde beslissing beziet Van Schilfgaarde deze problematiek vanuit een gezichtspunt waarin het vennootschapsrecht prevaleert. Hiervoor voert hij drie argumenten aan, namelijk de onderwerping van de overheidscommissaris aan art. 140 lid 2, het feit dat ook bij benoeming van overheidscommissarissen bij structuurvennootschappen ava en or invloed dienen te hebben -hetgeen niet mogelijk was bij de betrokken benoemingsafspraak- en vooral het feit dat afwijking van het vennootschapsrecht op een beschikking ex art. 156 dient te berusten. Als ik het goed zie, komen de drie argumenten er op neer dat de overheid aan het vennootschapsrecht gebonden is omdat zij binnen de vennootschappelijke orde opereert. Op zich is zulks juist, maar daarmee wordt echter de gestelde vraag niet beantwoord. Immers, niet wordt verklaard waarom de vennootschappelijke- en niet de publieke rechtsorde dient te prevaleren.

Naar mijn mening gaat het i.c. niet om een probleem van conflicterende rechtsordes, waarbij een van de twee prevaleert, maar van conflicterende belangen bij een handeling waarbij iemand in twee hoedanigheden betrokken is. In de zaak Streekvervoer deed zich het conflict bij de minister voor. Terwijl hij als bewindsman bepaalde toezeggingen had gedaan, was hij als benoemingsbevoegd vennootschapsorgaan onderworpen aan een ander rechtsregime. In deze tweede hoedanigheid kon hij niet anders handelen dan volgens de vennootschappelijke rechtsorde, althans, zoals Van Schilfgaarde terecht stelt, zolang hij niet ex art. 156 ontheven wordt van de toepasselijkheid van de vennootschapsrechtelijke bepalingen. In het geval van de overheidscommissaris is de situatie in wezen niet anders. Ook hij kan bij zijn taakvervulling als commissaris in een situatie verkeren van tegenstrijdigheid van belangen, indien hij in een andere hoedanigheid betrokken is bij dezelfde transactie. Het gaat ook hier niet om de vraag welke rechtsorde prevaleert, maar om het probleem van behoorlijke uitoefening van de commissariële taak. ${ }^{182}$

Het belangenconflict kan zich ook voordoen indien de overheidscommissaris in twee verschillende hoedanigheden onderworpen is aan de vennootschappelijk orde. Ook hier staat de behoorlijke taakuitoefening op het spel. In zoverre bestaat geen verschil met de zojuist geschetste problematiek. Illustratief in dit verband zijn de gerezen vragen over de mogelijke

182. Zie over de problematiek van het tegenstrijdig belang bij de taakvervulling van commissarissen $\S 18$. 


\section{OVERHEIDSCOMMISSARIS}

incompatibiliteit van de functie van overheidscommissaris met de functie van bestuurder van een prioriteitstichting, die tot doel heeft de belangen van de overheid te dienen. Bij de verzelfstandiging van de N.V. DSM heeft de minister zich op het standpunt gesteld "dat de stichting inderdaad in de eerste plaats wordt opgericht om de belangen van de Staat als grootaandeelhouder te behartigen, hetgeen niet wil zeggen dat de belangen van N.V. DSM geen rol spelen." ${ }^{183}$ Hoewel de helderheid van deze ministeriele uitspraak eerder met politieke, dan met juridische maatstaven lijkt te moeten worden gemeten, blijkt uit de door mij gecursiveerde woorden waar het probleem mijns inziens schuilt. Tegen het feit dat de Staat er op uit is zijn positie als grootaandeelhouder veilig te stellen is niets in te brengen. De Staat kan zulks doen zowel door aanwezig te zijn in de rvc als door de creatie van bijzondere rechten welke aan een door hem gecontroleerde prioriteitsstichting worden toegekend. De Staat kan het commissariaat in de vennootschap en de bestuurdersfunctie in de prioriteitsstichting aan dezelfde persoon opdragen. In beide gevallen zal de overheidscommissaris in het bijzonder acht slaan op de overheidsbelangen. Echter, bij zijn handelen als commissaris zal hij rekening dienen te houden met de belangen van alle aandeelhouders en van alle anderen aan wie de rechtsorde aanspraken geeft jegens de vennootschap. In zijn hoedanigheid van bestuurder van de stichting zal hij zich met andere belangen dan het aandeelhouderschap van de stichting niet bezig hoeven te houden.

De positie van de overheidscommissaris is, naar het mij voorkomt, niet wezenlijk anders dan die van andere belangen-commissarissen. Voor de uitoefening van zijn vennootschappelijke bevoegdheden gelden geen bijzondere normen. Hiertegenover zou kunnen worden gesteld dat het overheidsbelang een bijzondere, wellicht prevalerende plaats dient in te nemen omdat het van een andere orde is dan de particuliere belangen. Een afwijking van de vennootschappelijke normen omwille van het openbaar belang zou om deze reden toelaatbaar moeten worden geacht. Wij raken hier aan de algemene problematiek van het 'overheidsprivaatrecht'. Anders dan in het geval van het algemeen vermogensrecht, meen ik echter dat in het geldend vennootschapsrecht -afgezien dan van het ontheffingsregime bij structuurvennootschappen (art. 156)- geen ruimte is voor een bijzondere positie van de overheid. ${ }^{184}$

183. Tweede Kamer 1988-1989, 20.649, nr. 6, blz. 7. Zie ook de opmerkingen in de MvT, nrs. 3-4, blz. 7.

184. Vgl. hieromtrent Maeijer (1972), blz. 34: "het gehele vraagstuk van overheidsinvloed en overheidsparticipatie in bepaalde ondernemingen wordt tot nu toe in Nederland verbrokkeld, ad hoc, onsystematisch en weinig coherent behandeld." 


\section{Regeringswaarnemer}

Van de overheidscommissaris dient de figuur van de regeringswaarnemer te worden onderscheiden. De regeringswaarnemer is geen lid van het college van commissarissen. Hij is een persoon an wie bepaalde rechten jegens de vennootschap worden toegekend in het kader van een financieringsoperatie door de overheid. Veelal verkeert de vennootschap in een ongunstige situatie waarin de behoefte aan liquide middelen dringend is. De financiering door de overheid wordt met enige waarborgen omkleed. Een van deze waarborgen vormt de aan de regeringswaarnemer toegekende rechten, welke er op neer komen dat hij in de vennootschap als toezichthouder namens de overheid opereert. De rechten van de regeringswaarnemer ${ }^{185}$ ontstaan uit een tussen vennootschap en overheid gesloten overeenkomst.

Tegen het verbinden van strenge voorwaarden aan een risicovolle financiering kan uiteraard geen bezwaar bestaan en het is de gangbare praktijk van het kredietwezen. Er is echter reden om te twijfelen aan de geldigheid van enkele onderdelen van de overeenkomst waaraan de regeringswaarnemer zijn rechten ontleent. Dit betreft vooral de clausule die de regeringswaarnemer het recht verleent om de werking van vennootschapsbesluiten te schorsen. Op contractuele wijze wordt aldus getracht bepaalde toezichthoudende rechten toe te kennen aan de wederpartij van de vennootschap. Omdat de problematiek zich niet alleen kan voordoen in het kader van een financieringsoperatie door de overheid maar ook in een normaal

185. Zie voor een opsomming van deze rechten de Model taakomschrijving regeringswaarnemer, Staatscourant 1977, 72, blz. 6:

Voor de goede uitvoering van deze taken zal de vennootschap u de navolgende bevoegdheden verlenen:

a. $U$ zult tijdig over dezelfde informatie kunnen beschikken als de directie en de raad van commissarissen, teneinde de gang van zaken in de onderneming adequaat te kunnen volgen;

b. U zult tegen een besluit van de directie, de raad van commissarissen (de vergaderingen van aandeelhouders en prioriteitsaandeelhouders) bezwaar kunnen maken in welk geval de uitvoering van dat besluit wordt opgeschort totdat ik mij via het Bureau Bijzondere Bedrijfsproblemen, na onverwijld overleg met de vennootschap, hierover heb uitgesproken. Indien ik mij binnen zes weken na de door u gemaakte bezwaren niet overeenkomstig bovenstaande heb uitgesproken, wordt het besluit geacht uitgevoerd te kunnen worden;

c. U zult onder toezending van agenda en stukken uitgenodigd worden en gerechtigd zijn alle vergaderingen van de raad van commissarissen (en van prioriteitsaandeelhouders) alsmede de algemene vergadering van aandeelhouders bij te wonen. Wanneer $u$ dit nodig acht zal op uw verzoek een dergelijke vergadering kunnen worden uitgeschreven;

d. $U$ zult rechtstreeks met de directie en eventuele externe adviseurs contact kunnen opnemen en met hen overleg kunnen plegen. 


\section{REGERINGSWAARNEMER}

geval van kredietverlening, zou ik over de toezichthoudende rechten van de regeringswaarnemer het volgende willen opmerken.

De regeringswaarnemer -en hetzelfde geldt voor elke andere 'particuliere waarnemer'- is niet een orgaan van de rechtspersoon. ${ }^{186}$ Zijn rechten jegens de vennootschap zijn van contractuele aard. Tegenover de kredietverlener verbindt de vennootschap zich om bepaalde bevoegdheden al of niet uit te oefenen, dan wel om zulks slechts onder bepaalde voorwaarden te doen. Voorts verleent de vennootschap aan de regeringswaarnemer, als vertegenwoordiger van haar schuldeiser, een aantal rechten. Hierbij rijst in het bijzonder de vraag of de vennootschap aan een derde het recht kan geven om de werking van eigen besluiten te schorsen. Naar het oordeel van Honée ${ }^{187}$ is dit niet mogelijk. Na een indringende vergelijking van de vermogensrechtelijke autonomie van de mens met die van de rechtspersoon, komt hij tot de conclusie dat "juist, omdat de ethische dimensie ontbreekt, de aan de vennootschap toebedeelde vermogensrechtelijke autonomie een sterk gebonden karakter heeft. In die zin dat deze autonomie haar niet om haar eigentwille is gegeven maar omwille van de in haar geïncorporeerde belangen -die van aandeelhouders- en omwille van de belangen die rechtstreeks zijn verbonden met de door de vennootschap ontwikkelde economische activiteiten -ik noem met name die van crediteuren en van werknemers-. Ik meen dat men, gegeven het wettelijk stelsel, niet anders dan zó kan redeneren. Alleen dan is inzichtelijk waarom de wet de door haar genormeerde organisatieregels tot dwingend recht verklaart. ${ }^{188}$ Honée ${ }^{189}$ onderbouwt zijn stelling aan de hand van het in het Duitse recht bestaande Beherrschungsvertrag. Een dergelijke beheersovereenkomst komt -voor zover hier van belang- er op neer dat de rechtspersoon bij zijn besluitvorming zich zal gedragen naar de aanwijzingen van een ander rechtssubject. Als ik het goed zie, houdt de argumentatie van Honée in dat de rechtsorde aan de rechtspersoon verbiedt over de eigen autonomie te beschikken omdat bepaalde in haar geïncorporeerde belangen zulks eisen. $\mathrm{Nu}$ in onze rechtsorde de belangen van derden die met de rechtspersoon handelen niet worden beschermd op een manier als in het Duitse recht geschiedt door middel van de regeling van de beheersovereenkomst, kan de rechtspersoon naar Nederlands recht haar autonomie niet prijsgeven.

Ik zou menen dat de problematiek aldus niet correct wordt gesteld en dat het uitgangspunt het omgekeerde moet zijn. Mij dunkt dat de autonomie van de rechtspersoon haar verklaring vindt niet in de bescherming van de

186. Zo ook Van der Burg (1983), blz. 331.; Honée (1983), blz. 6 e.v.

187. Rede 1983, blz. 19.

188. T.a.p., blz. 19.

189. (1983), blz. 16 e.v. 
belangen van derden maar überhaupt in het eigen bestaan van de rechtspersoon. De autonomie is conditio sine qua non van de rechtspersoonlijkheid. Het is niet bestaanbaar dat de rechtspersoon kan handelen -bijvoorbeeld dat hij aan een derde, de regeringswaarnemer, zeggenschap geeft in zijn besluitvorming- zonder dat hij zulks in de uitoefening van zijn autonomie doet. Doch deze autonomie is bij de rechtspersoon evenzeer als bij de mens door de rechtsorde bepaald. Het handelen van de rechtspersoon en van de mens kan, om rechtens te kunnen gelden, alleen plaatsvinden binnen de grenzen van de rechtsorde. ${ }^{190}$ Toegepast op de hier aan de orde zijnde problematiek betekent dit dat de vennootschap aan de regeringswaarnemer dit is, een 'derde' in de meest strikte zin des woords- niet de macht kan geven om de werking van zijn besluiten te schorsen: zichzelf onder diens curatele te stellen. Zulks omdat de wil van de rechtspersoon alleen kan worden bepaald door de instanties (organen) aan wie de rechtsorde die macht geeft. ${ }^{191}$ Aangezien onze rechtsorde aan de regeringswaarnemer deze macht onthoudt, kan de vennootschap hem die ook niet geven.

Wellicht kan dit worden toegelicht aan de hand van het voorbeeld van de beheersovereenkomst. Verdedigd zou kunnen worden dat een beheerste rechtspersoon geen autonomie heeft omdat niet hijzelf maar een ander rechtssubject bepaalt hoe hij zijn rechten zal uitoefenen. Echter, ook in dit geval is de besluitvorming van de beheerste rechtspersoon het resultaat van zijn eigen autonomie. Zijn besluiten gelden als wilsverklaringen welke hij in de uitoefening van zijn autonomie verricht. Dat de rechtsorde toestaat dat een derde invloed heeft op de wilsverklaringen van de beheerste rechtspersoon -waarbij het eigen vermogen van de derde de consequenties van deze beïnvloeding draagt- betekent niet dat de beheerste rechtspersoon geen autonomie heeft. Het betekent slechts dat de beheerste rechtsperspersoon op een bepaalde manier dienstbaar is aan de belangen van een derde, maar hij is dat in de uitoefening van zijn autonomie.

Zonder meer moet overigens aan Honée worden toegegeven dat de wetgever zich bij de bepaling van de grenzen van de autonomie van de rechtspersoon -evenals van de mens- laat leiden door een waardering van de op het spel staande belangen. Maar deze kwestie is van een andere orde dan de hier besprokene.

190. Door Flume (1979), blz. 1, is dit op kernachtige wijze uitgedrukt: "Die Privatautonomie erfordert begrifflich die Rechtsordnung als Korrelat."

191. Zo zou bijvoorbeeld de rechtsorde kunnen bepalen dat de goedkeuring van de rvc noodzakelijk is alvorens het bestuur de vennootscahp bindt terzake van bepaalde rechtshandelingen, met andere woorden dat de goedkeuring van art. 164 externe werking zou hebben. Het feit dat deze goedkeuring noodzakelijk is betekent echter niet dat de vennootschap niet autonoom is, dat zij onder de curatele van de rvc staat. 
De conclusie die uit het voorgaande moet worden getrokken is dat, nu onze rechtsorde niet toestaat dat een contractuele wederpartij van de vennootschap de werking van de besluiten van laatstgenoemde schorst, de vennootschap zich niet rechtsgeldig kan binden om aan een regeringswaarnemer de in de Modelbrief genoemde opschortingsrechten toe te kennen.

Van voorgaande problematiek moet worden onderscheiden de vraag naar de geldigheid van een overeenkomst waarbij de vennootschap zich zou verbinden om bepaalde besluiten niet of slechts onder de door de wederpartij gestelde voorwaarden uit te voeren. Inhoud van de overeenkomst is dan het nalaten van een bepaalde handeling, en niet de wilsvorming van de vennootschap. Tegen een dergelijke overeenkomst kan geen bezwaar bestaan. Op dezelfde manier als de vennootschap vrij is om een bepaalde handeling al of niet te verrichten, is zij vrij om zich daarbij afhankelijk te maken van de medewerking van een derde. Wanneer zij ondanks de overeenkomst uitvoering zou geven aan het besluit, zou zij wanprestatie plegen. De werking van het besluit wordt daardoor echter niet belet.

De overige rechten van de regeringswaarnemer, namelijk tot het verkrijgen van informatie, tot het bijwonen van de vergaderingen van de rvc en tot overleg met werknemers van de vennootschap en met haar adviseurs, zijn mijns inziens op zichzelf toelaatbaar. Van strijdigheid met het dwingend vennootschapsrecht is naar mijn mening geen sprake. ${ }^{192}$ Alle genoemde rechten komen er op neer dat de wederpartij van de vennootschap gerechtigd is tot informatie over de beleidsvoering. Ik zie niet in hoe, in de gegeven omstandigheden, het ter beschikking stellen van informatie ongeoorloofd kan zijn. Bezien vanuit het perspectief van de wederpartij is zulks, in de hier aan de orde zijnde gevallen, zelfs geboden ter bescherming van de eigen belangen. Dat de informatie niet voor oneigenlijke doelen niet mag worden gebruikt spreekt voor zich. Het enkele feit dat het risico bestaat, dat de informatie ten nadele van de vennootschap kan worden gebruikt, tast echter de geldigheid van de overeenkomst niet aan.

Voor zover de autonomie van de vennootschap in stand blijft zie ik geen bezwaar tegen de figuur van de regeringswaarnemer, zoals mijns inziens overigens ook geen bezwaar bestaat tegen de figuur van bankwaarnemer, werknemerswaarnemer of een andere belangenwaarnemer.

192. Anders echter Van Schilfgaarde, NJB 1984, blz. 1265, met betrekking tot het vergaderrecht, dat hij als strijdig met de "vennootschappelijke orde" beschouwt. 


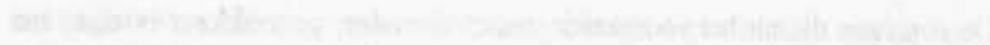

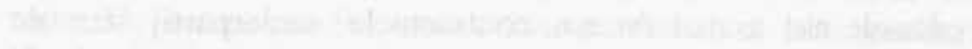

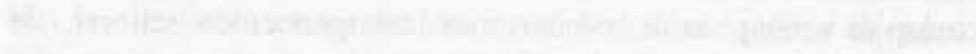

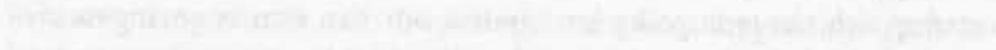

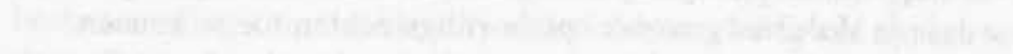

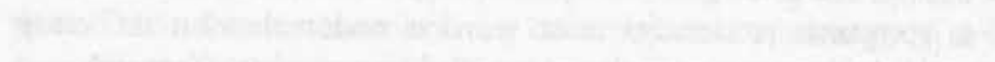

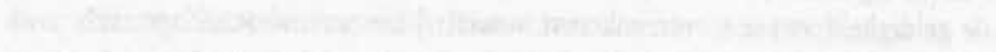

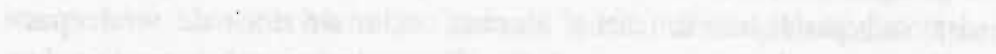
1

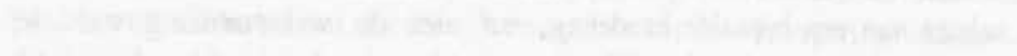

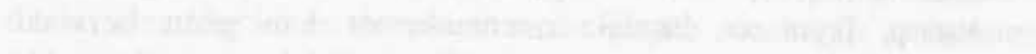

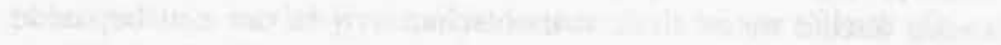

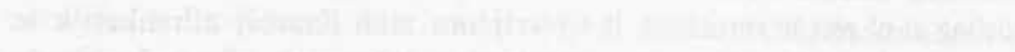

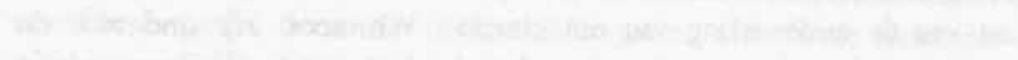

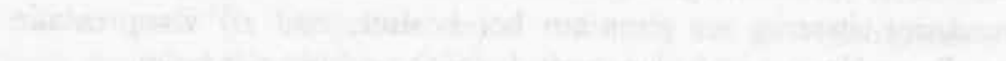

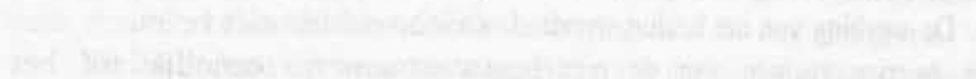

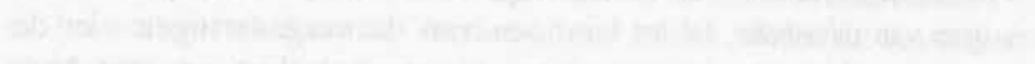

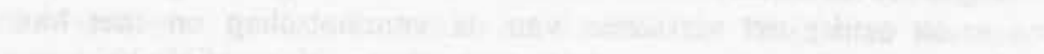

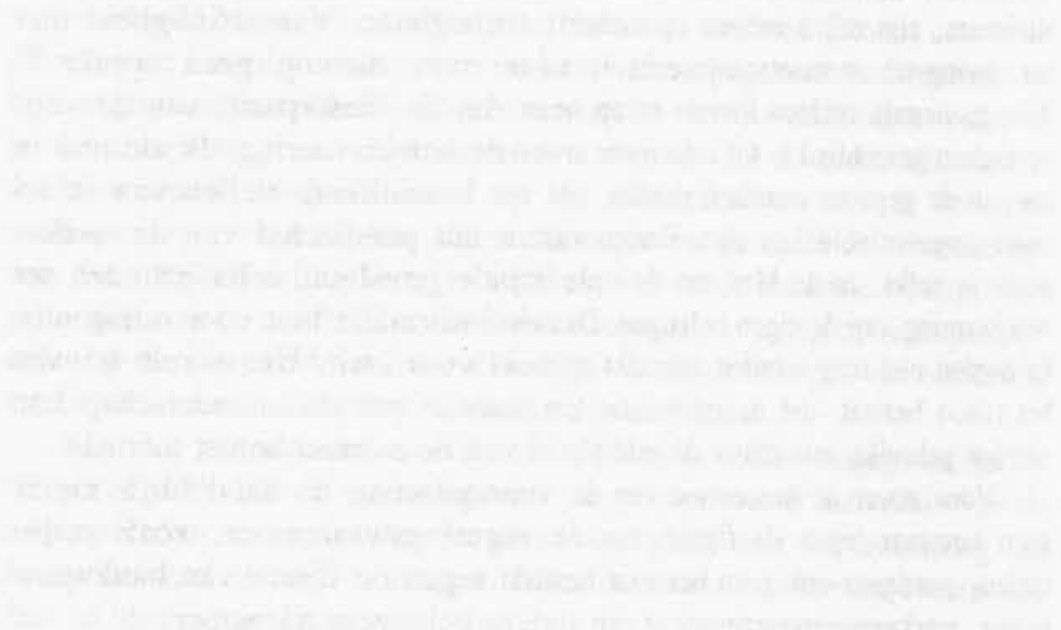




\section{HOOFDSTUK IV}

\section{Taakvervulling en aansprakelijkheid}

Iedere commissaris is gehouden tot een behoorlijke vervulling van de hem opgedragen taak (artt. 149 jo. 9). Onontbeerlijk is deze uitspraak van de wetgever niet ${ }^{1}$ omdat het vanzelfsprekend is dat degene die een verplichting dient na te komen zulks op behoorlijke wijze dient te doen. Voorts bepaalt de wet dat de commissaris die zijn taak onbehoorlijk vervult gehouden is tot vergoeding van de daaruit ontstane schade en dat commissarissen onder omstandigheden aansprakelijk kunnen zijn voor schade, die het gevolg is van onbehoorlijke taakvervulling door medecommissarissen.

Aansprakelijkheid wegens onbehoorlijke taakvervulling vereist de schending van een vennootschapsrechtelijke bepaling. In zoverre kan men zeggen dat de aansprakelijkheid primair een vennootschapsrechtelijk karakter heeft. Daarnaast kan de commissaris aansprakelijk zijn wegens overtreding van een andere norm, waarbij in het bijzonder dient te worden gedacht aan art. 6:162 BW. Mogelijk is tenslotte dat de commissaris aansprakelijk is wegens de niet nakoming van een overeenkomst waarbij de commissaris partij is. Hiervoor is reeds gesteld dat van een dergelijke relatie tussen commissaris en rechtspersoon geen sprake behoeft te zijn. ${ }^{2}$ Op deze plaats zal slechts worden ingegaan op de vennootschapsrechtelijke aansprakelijkheid. De contractuele en delictuele aansprakelijkheid komen slechts aan de orde voor zover dat van belang is in het kader van de onbehoorlijke taakvervulling op grond van art. 9.

De schade die uit onbehoorlijke taakvervulling door de commissaris ontstaat, kan worden geleden door de rechtspersoon of door derden. In de literatuur worden de termen interne en externe aansprakelijkheid gebruikt om het verschil in benadeelde persoon aan te duiden. Zoals later zal blijken zijn deze termen mijns inziens niet correct omdat onbehoorlijke taakvervul-

1. Zo ook Asser-Van der Grinten II, nr. 44.

2. $\$ 12$. 
ling per definitie jegens de rechtspersoon plaatsvindt. Niet de persoon van de gelaedeerde is in dit kader van belang maar de overtreden norm.

\section{Aansprakelijkheid wegens onbehoorlijke taakvervulling}

\section{Aansprakelijkheid jegens de rechtspersoon}

De bepaling dat de commissaris gehouden is tot een behoorlijke taakvervulling (art. 9) is een open norm die concretisering behoeft.

Over inhoud en strekking van deze norm bestaat mijns inziens onduidelijkheid. Wellicht verklaart dit waarom aansprakelijkheid van bestuurders en commissarissen "in de praktijk van het rechtsleven (...) niet een rol van enige betekenis" speelt. ${ }^{3}$ Een nadere analyse van art. 9 lijkt mij gewenst.

Bij het aansprakelijkheidsvraagstuk hebben wetgever en literatuur met name de onbehoorlijke taakvervulling door bestuurders op het oog. Aansprakelijkheid van commissarissen is hiervan slechts een afgeleide. De rechtsverhouding tussen commissaris en vennootschap wordt beoordeeld met behulp van normen die voor de verhouding tussen vennootschap en bestuurder gelden. Deze normen worden analoog van toepassing verklaard (art. 149). Zowel voor grotere aandacht voor de aansprakelijkheid van bestuurders als voor de analogische toepassing van genoemde normen bestaan goede gronden. In de eerste plaats brengt de leidinggevende taak van het bestuur met zich mee dat de feitelijke werkzaamheden van zijn leden mijns inziens beter bepaalbaar zijn dan de toezichthoudende werkzaamheden van commissarissen. Daardoor is het in het algemeen gemakkelijker te constateren wanneer de uit de leidinggevende taak voortvloeiende verplichtingen geschonden zijn. In de tweede plaats is analogische toepassing van normen, die voor bestuurders bedoeld zijn, op commissarissen gerechtvaardigd, indien men met mij aanvaardt dat de rechtsverhouding van beide ambtsdragers tot de rechtspersoon van gelijke aard is. Uitgaande van deze gelijkheid worden beide aansprakelijkheden door dezelfde beginselen beheerst, en in zoverre verschilt de aansprakelijkheid van de leidinggever niet van die der toezichthouder. Dit brengt met zich mee dat hetgeen hierna zal worden opgemerkt over onbehoorlijke taakvervulling door commissarissen ook geldt voor de bestuurders, voor zover het gaat om de beginselen die aan de aansprakelijkheidsregeling ten grondslag liggen. ${ }^{4}$ Het punt van verschil ligt

3. Zo Van der Grinten, de NV 60 (1982), blz. 201.

4. Hierna zal op een enkele plaats over commissarissen en bestuurders zonder onderscheid worden gesproken. 
in de verschillende taakstellingen binnen de vennootschap en komt tot uitdrukking in de verschillende feitelijke invulling van de normen. ${ }^{5}$

\section{a) Onbehoorlijke taakvervulling}

Onbehoorlijke taakvervulling houdt in schending door de commissaris van de op hem rustende wettelijke of statutaire verplichtingen. Wanneer ten gevolge hiervan voor de vennootschap schade ontstaat kan de commissaris gehouden zijn tot vergoeding van de schade. Mogelijk lijdt de rechtspersoon geen vermogensrechtelijk nadeel. In dat geval ontstaat voor de commissaris geen verplichting tot schadevergoeding. Echter, indien hij door zijn taak onbehoorlijk te vervullen jegens de rechtspersoon onrechtmatig heeft gehandeld, kan de rechtspersoon in de vennootschapsrechtelijke verhouding maatregelen jegens de commissaris nemen. Beëindiging van het commissariaat kan bijvoorbeeld een gevolg zijn van onbehoorlijke taakvervulling. ${ }^{6}$

Uit het voorgaande blijkt dat onbehoorlijke taakvervulling en aansprakelijkheid van elkaar moeten worden onderscheiden. ${ }^{7}$ Het begrip onbehoorlijke taakvervulling verwijst naar het geheel van wettelijke en statutaire rechten en plichten van de commissaris, en wel in dier voege dat betrokkene genoemde rechten en plichten (zijn ambt) niet heeft uitgeoefend zoals de rechtsorde dit vereist. ${ }^{8}$ Aansprakelijkheid is een mogelijk rechtsgevolg dat de rechtsorde verbindt aan onbehoorlijke taakvervulling. Aansprakelijkheid is de op de commissaris rustende gehoudenheid tot vergoeding van de, ten gevolge van zijn onbehoorlijke taakvervulling, aan de vennootschap toegebrachte schade.

Anderzijds zijn onbehoorlijke taakvervulling en aansprakelijkheid niet van elkaar onafhankelijke categorieën. In de opzet van art. 9 is onbehoorlijke taakvervulling het rechtsfeit waaruit aansprakelijkheid ontstaat. Houdt men deze verbinding niet in het oog, dan kan men tot ongerijmde resultaten komen. Zo stelt Eykman dat terwijl eerstgenoemd begrip een resultaatsge-

5. Vgl. hierover Geßler, Aktiengesetz, § 116, Rn. 9.

6. Zulks kan bij structuurvennootschappen van belang zijn omdat onbehoorlijke taakvervulling een ontslaggrond kan opleveren (art. 162).

7. Zie voor allen Eykman, TVVS 1986, blz. 87.

8. Op dit punt kan de terminologie van Eykman (TVVS 1986, blz. 87, die zich op zijn beurt op G.H.A. Schut, Rechtelijke verantwoordelijkheid en wettelijke aansprakelijkheid, beroept) worden gevolgd. De verplichting tot behoorlijke taakuitoefening duidt hij aan met de term 'verantwoordelijkheid'. Evenzo, Maeijer (1991), blz. 3.

9. T.a.p. blz. 87 . 
bondenheid inhoudt, aansprakelijkheid slechts een inspanningsgebondenheid inhoudt. Hieruit zou volgen dat de commissaris bij zijn taakvervulling tegelijk wel en niet gehouden is tot het bereiken van een bepaald resultaat. Dit verschil wordt door deze schrijver aldus verklaard dat verantwoordelijkheid en aansprakelijkheid "verschillende terreinen bestrijken".

Ik denk dat op deze wijze de verhouding tussen beide begrippen niet correct wordt gesteld. Met de gehoudenheid van de commissaris tot een behoorlijke taakvervulling heeft de aansprakelijkheid als zodanig niets te maken. Aansprakelijkheid is, zoals gezegd, het mogelijke gevolg van een onrechtmatig handelen jegens de rechtspersoon. De gehoudenheid tot behoorlijke taakvervulling gaat aan aansprakelijkheid vooraf. Behoorlijke taakvervulling houdt in correcte uitoefening door de commissaris van het geheel van zijn rechten en plichten. Onbehoorlijke taakvervulling is de rechtsgrond waarop aansprakelijkheid gebaseerd is. Naar mijn mening zijn aansprakelijkheid en de verplichting tot behoorlijke taakvervulling niet twee gehoudenheden, die ieder tot een ander handelen verplichten. Stricto sensu is de commissaris slechts tot een behoorlijke taakuitoefening gehouden. Het geheel van normen die zijn taak regelt bepaalt hoe hij dient te handelen. Schiet hij daarin tekort, dan is hij voor de ontstane schade aansprakelijk. Op dit punt geldt hetgeen Larenz opmerkt omtrent de nakoming van verbintenissen. Hij maakt onderscheid tussen datgene waarvoor de schuldenaar verantwoordelijk is en de rechtsgevolgen die intreden wanneer hij verantwoordelijk is. ${ }^{10}$

De vaststelling van de rechten en plichten van de commissaris dient te geschieden op grond van wet en statuten. Bepalend zijn daarbij met name de aan de raad van commissarissen ${ }^{11}$ toekomende bevoegdheden omdat onze wet de taakvervulling van de individuele commissarissen verstaat als deelname aan de collectieve taak van de raad. Behoorlijke taakvervulling is dan ook geen absoluut begrip. Het is afhankelijk van de aan de rvc en aan zijn leden in concreto toegekende bevoegdheden. ${ }^{12}$ Bij een structuurvennootschap zal behoorlijke taakvervulling een andere inhoud hebben dan bij

10. Larenz (1987), blz. 276.

11. De verhouding tussen collectieve verantwoordelijkheid van de rve enerzijds en onbehoorlijke taakvervulling en aansprakelijkheid van de individuele commissaris anderzijds zal aan de orde komen bij de bespreking van art. 138. Zie hierna $\$$ $17, \mathrm{II}, \mathrm{c}$.

12. In zoverre is de uitspraak van de Rechtbank Amsterdam d.d. 16 december 1959 (NJ 1962, 202) juist. Aldaar wordt geen aansprakelijkheid van commissarissen aangenomen terzake van wanbeleid van de directie omdat "de oprichters der N.V. de taak van commissarissen hebben willen beperken tot adviserende werkzaamheden." Of aan de rve -ook onder het oude recht- een louter adviserende taak kon worden toebedeeld is een andere vraag. 
een gewone vennootschap. Ook zal het van de statuten afhangen waartoe een behoorlijke taakvervulling verplicht. Indien bijvoorbeeld wettelijk of statutair voor de rvc een goedkeuringsrecht terzake van bepaalde bestuursbesluiten ingeruimd is, vervullen commissarissen hun taak onbehoorlijk indien het besluit in kwestie ten onrechte wordt genomen en zij daaraan toch hun goedkeuring hechten. Bestaat een dergelijk goedkeuringsrecht niet, dan dragen commissarissen niet zonder meer de verantwoordelijkheid voor het besluit. Onbehoorlijke taakuitoefening zal hen in ieder geval niet verweten kunnen worden terzake van het niet tegenhouden van het gewraakte besluit. ${ }^{13}$

Uitgaande van het rechtspersonenrechtelijke karakter van de rechtsverhouding tussen commissaris en vennootschap, vereist onbehoorlijke taakvervulling schending van een vennootschapsrechtelijke norm door de commissaris. Geheel correct lijkt mij dan ook niet de stelling van Maeijer dat "art. 9 de verplichtingen [betreft] van de bestuurder jegens de vennootschap tot wie de bestuurder in een contractuele verhouding staat. Men zou kunnen zeggen dat art. 9 een wettelijke bevestiging en uitwerking geeft aan hetgeen de overeenkomst tussen bestuurder en vennootschap voor die bestuurder inhoudt en aan de (eventuele) aansprakelijkheid van de bestuurders verenigd in een bestuurscollege. Men spreekt in dit verband wel over de interne aansprakelijkheid. "14 Hiervoor ( $\$ 7$, I en $\S 12$ ) is reeds betoogd dat de vennootschappelijke verhouding van bestuurders en commissarissen tot de rechtspersoon onderscheiden moet worden van andere mogelijke verhoudingen van contractuele aard. De noodzaak van deze onderscheiding blijkt in het geval van de aansprakelijkheid uit onbehoorlijke taakvervulling. Deze aansprakelijkheid ontstaat niet uit de schending van contractuele plichten maar uit de schending van art. 9. Het belang van de onderscheiding is gelegen in het mogelijk verschil van rechtsregime tussen contractuele en vennootschappelijke normen. Hierna zal blijken dat bijvoorbeeld terzake van de verwijtbaarheid van de onbehoorlijke handeling die tot schadevergoeding leidt een zodanig verschil in rechtsregime bestaat. Het verschillend rechtsregime kan wel in zoverre relatief zijn dat, zoals Maeij$\mathrm{er}^{15}$ terecht stelt, "art. 9 moet (...) worden geplaatst tegen de achtergrond van art 6:74 en 6:75 NBW, die toepasselijk zijn voor zover niet een

13. Iets anders is dat de rvc de transactie in kwestie met andere middelen kon tegen houden, bijv. door de handelende bestuurder te schorsen. Alsdan rust de verantwoordelijkheid van de commissarissen niet op art. 164 maar op art. 161. Zie over deze materie $\S 9$.

14. (1991) blz. 4. Curs. ook in het origineel. Maeijer heeft weliswaar de bestuurders op het oog, doch in zoverre zijn betoog over art. 9 in het algemeen gaat leid ik 15. T.a.p. 
bijzondere regeling is gegeven." Zonder nu in te gaan op de vraag of de vennootschappelijke verhouding er een is van obligatoire aard, lijkt mij in ieder geval dat de analogie tussen de vennootschappelijke en contractuele verhoudingen (vooral de arbeidsovereenkomst en de overeenkomst tot het verrichten van enkele diensten) de toepassing art. 6:74 e.v. rechtvaardigt. Dit betekent dat iedere tekortkoming in de vervulling van zijn taak, iedere schending van zijn wettelijke en statutaire plichten in beginsel tot onbehoorlijke taakvervulling en, voor zover sprake is van vermogensrechtelijk nadeel voor de vennootschap, tot aansprakelijkheid jegens haar leidt.

Op dit punt doet zich dezelfde moeilijkheid voor als in het gemene recht. Het begrip tekortkoming is een neutraal begrip, met dien verstande dat aansprakelijkheid slechts intreedt indien de tekortkoming toerekenbaar is. Om het verschil tussen al of niet toerekenbare tekortkoming an te duiden pleegt men in civilibus de termen 'wanprestatie', resp. 'overmacht' te gebruiken. ${ }^{16}$ De term onbehoorlijke taakvervulling houdt naar mijn mening in dat de tekortkoming aan de commissaris is toe te rekenen. Het woord onbehoorlijk betekent mijns inziens dat de gedraging verwijtbaar is. Maar dit taalkundig bezwaar lijkt mij onvoldoende om te dier zake anders te oordelen, dan in het geval van niet nakoming van verbintenissen. Evenals iedere toerekenbare tekortkoming in beginsel tot aansprakelijkheid leidt, betekent iedere schending van vennootschappelijke plichten van de commissaris onbehoorlijke taakvervulling, en voor zover daaruit schade voortvloeit tot aansprakelijkheid.

Overigens impliceert het feit dat onbehoorlijke taakvervulling de schending van een vennootschapsrechtelijke norm vereist geenszins dat schending van andere normen irrelevant zou zijn voor de vennootschappelijke verhouding. Indien de commissaris bijvoorbeeld zakelijke relaties onderhoudt met de vennootschap waar hij commissaris is, kan dit een omstandigheid zijn die zijn taakvervulling beïnvloedt. Niet nakoming van zijn contractuele verplichtingen jegens de vennootschap kan een rol spelen bij de beoordeling van zijn taakvervulling. Ook het handelen van de commissaris in privé (bijvoorbeeld het plegen van een onrechtmatige daad jegens een ander dan de vennootschap) kan repercussies hebben voor zijn taakvervulling. In deze gevallen brengt de schending van contractuele of wettelijke verplichtingen niet uit zichzelf onbehoorlijke taakvervulling met zich mee. Het zijn echter omstandigheden die nader inhoud kunnen geven aan de verhouding tussen commissaris en vennootschap (art. 8).

Onbehoorlijke taakvervulling doet zich niet alleen voor wanneer commissarissen in strijd handelen met positiefrechtelijke en statutaire verplichtingen, maar ook indien de uitoefening van hun bevoegdheden niet

16. Zie Asser-Hartkamp II, nr. 309. 
op de best mogelijke wijze geschiedt. In dit verband schrijft Meijers ${ }^{17}$ : "Naast het inachtnemen van hetgeen de statuten of besluiten voorschrijven, verlangt men van den directeur een behoorlijk beleid. Ook al is de handeling volkomen rechtmatig binnen de grenzen van statuten en besluiten, de directeur wordt aansprakelijk, indien hij voor de belangen van de N.V. niet voldoende zorg heeft gedragen." De verplichting tot het voeren van een "behoorlijk (toezichts-)beleid" brengt voor commissarissen, naast de gehoudenheid om te handelen in het belang van de vennootschap (art. 140), ook de plicht mee om de besluiten op correcte wijze voor te bereiden en uit te voeren. ${ }^{18}$ Het betreft hier de zorgvuldigheid waarmee de commissaris zijn taak dient uit te oefenen. ${ }^{19}$ Op dit punt beschikt de commissaris over een zekere beoordelingsvrijheid waarbinnen hij zijn bevoegdheden naar eigen inzicht uitoefent. De rechterlijke toetsing van dit handelen dient het oordeel van de handelende commissaris in belangrijke mate te respecteren, omdat aan de wet niet meer dan een vage gedragsnorm kan worden ontleend. Naar analogie van art. 6:27 BW dient de commissaris zich als een zorgvuldige commissaris in de gegeven omstandigheden te gedragen. ${ }^{20} \mathrm{De}$ taakuitoefening is slechts onrechtmatig wanneer het voor de commissaris duidelijk had moeten zijn dat een zorgvuldige commissaris anders had dienen te handelen.

Met het vaststellen van de normen waaraan de taakvervulling dient te beantwoorden is de vraag naar de concrete invulling ervan nog niet beantwoord. Wat behoorlijke taakvervulling inhoudt hangt af van de concrete situatie. Naast de verscheidenheid aan rechten en plichten welke zich in de praktijk kan voordoen, is het dynamisch karakter van de taakvervulling -in die zin dat zij de uitoefening van bedoelde rechten inhoudt- een omstandigheid die het formuleren van een algemene gedragsnorm voor alle commissarissen in de weg lijkt te staan. Toch kan mijns inziens een gedragsnorm worden gegeven. De verplichting tot behoorlijke taakvervulling concretiseert zich in eerste instantie in de verplichting om geïnformeerd te

17. Aansprakelijkheid en décharge van directeuren van naamloze vennootschappen, Purmerend 1923, blz. 16.

18. Uitvoerig hierover Van Leeuwen (1990), passim.

19. Vgl. AktG \& 93, Abs. 1: "Die Vorstandmitglieder haben bei ihrer Geschäftsführung die Sorgfalt eines ordentlichen und gewissenhaften Geschättsleiters anzuwenden (...)". Abs. 2: "Vorstandmitglieder, die ihre Pflichten verletzen, sind der Gesellschaft zum Ersatz des daraus entstehenden Schadens als Gesamtschuldner verplichtet". §93 is op grond van $\S 116$ van overeenkomstige toepassing op de leden van de Aufsichtsrat.

20. Zie in dit verband het door IJsselmuiden (noot onder HR 10 januari 1990 (OGEM), TVVS 1990, blz. 129) gemaakt onderscheid tussen vage normen die naar een bepaalde maatstaf verwijzen en vage normen die geen materiële regeling bevatten. 
zijn omtrent datgene wat het vennootschappelijk belang in belangrijke mate raakt. In het eerste hoofdstuk is betoogd dat de toezichthoudende taak van commissarissen bestaat in het controleren dat het vennootschappelijke doel verwezenlijkt wordt. Geïnformeerd zijn omtrent de gang van zaken binnen de vennootschap is de eerste voorwaarde daartoe. Deze informatieplicht van commissarissen betreft vooral bestuursaangelegenheden. De informatie kan aanleiding geven tot het treffen van maatregelen. Hiertoe zal in het bijzonder aanleiding bestaan wanneer de resultaten van de vennootschap onbevredigend worden geacht. Uit art. 9 jo. 140 volgt dat commissarissen binnen het kader van hun bevoegdheden gehouden zijn om de maatregelen te treffen die zij in het belang van de vennootschap passend achten. Dit echter niet als een plaatsvervangend bestuur maar als een controlerende instantie, dat wil zeggen als iemand die er voor dient te zorgen dat doelstellingen, die anderen hebben gesteld, bereikt worden. Het is vooral op dit punt dat de vergelijking met de bestuurders niet opgaat. De commissaris kan, gezien zijn taak, slechts in beperkte mate "maatregelen treffen" om de gevolgen van onbehoorlijk bestuur af te wenden. ${ }^{21}$ Dat behoort tot de leidinggevende taak. De door de commissaris te treffen maatregelen zullen zich veelal in de interne sfeer van de vennootschap afspelen: het informeren van de overige commissarissen, het aandringen op wijziging van het beleid (door het bestuur), etc. Als ultimum remedium zal de commissaris zijn functie moeten neerleggen wanneer hij zich niet langer kan verenigen met het vennootschappelijk beleid. ${ }^{22}$

Behoorlijke taakvervulling houdt ook in de uitoefening van de commissariële rechten en plichten zoals het belang van de vennootschap dat vordert. Wat zulks mede brengt $\mathrm{zal}$ in ieder concreet geval moeten worden beoordeeld. Een aanwijzing van onbehoorlijke taakvervulling kan zijn dat het handelen of nalaten van de commissaris schade heeft berokkend aan de rechtspersoon of hem persoonlijk voordeel heeft opgeleverd. ${ }^{23}$

Voorzover alle commissarissen een gelijke rechtspositie hebben, is hun verantwoordelijkheid dezelfde. In beginsel is er dan ook geen reden om aan te nemen dat op een bepaalde commissaris verscherpte verantwoordelijkheid rust. Als uitzondering op dit beginsel kan de gedelegeerde commissaris gelden, daar het wezen van zijn ambt juist hierin gelegen is dat hij

21. In deze zin ook Van den Hoek (1986), blz. 78. Zie voor een feitelijke invulling van de toezichthoudende taak vgl. Glasz (1992), blz. 75 e.v.

22. Zie hieromtrent de algemene opmerkingen onder $\$ 1, \mathrm{I}$.

23. Zie nader hierover $\$ 18$. 
belast is met een meer regelmatig toezicht. ${ }^{24}$ Hieruit volgt ook dat in geval van delegatie van bevoegdheden voor concrete gevallen op de ad hoc gedelegeerde eveneens een zwaardere verantwoordelijkheid rust, zonder dat zulks overigens de rvc bevrijdt van zijn collectieve verantwoordelijkheid voor de betrokken handelingen.

Naar mijn mening brengt het enkele feit dat de president-commissaris voorzitter van de raad is geen verzwaarde verantwoordelijkheid mee omdat voor het overige het geheel van zijn rechten en plichten gelijk is aan dat van de andere commissarissen. Het voorzitterschap kan een zuiver intern karakter hebben. Het kan zich beperken tot de formele leiding van de vergaderingen van de rvc. Bijzondere verplichtingen -waaruit een zwaardere verantwoordelijkheid zou volgen- brengt zulks niet mede.

Uit dit alles volgt dat de verantwoordelijkheid van de commissaris een objectieve, door het ambt bepaalde inhoud heeft. Zou men kunnen stellen dat het commissariaat een resultaats- en geen inspanningsverplichting inhoudt? Naar mijn mening moet men hier onderscheiden. De aanvaarding van het ambt houdt niet meer in dan dat de benoemde persoon naar beste kunnen zich zal inzetten voor de uitoefening van de aan het ambt verbonden rechten en plichten. In zoverre is hij niet tot een concreet resultaat verbonden en kan men stellen dat op de commissaris slechts een inspanningsverbintenis rust. ${ }^{25}$ Anderzijds is het niet voldoende dat de benoemde persoon zich naar beste kunnen inspant om reeds van een behoorlijke taakvervulling te kunnen spreken. Door de aanvaarding van het ambt staat de commissaris er voor in dat hij in staat is de commissariële rechten en plichten uit te oefenen, welke een objectieve inhoud hebben. De commissaris dient, met andere woorden, aan de eisen te voldoen die aan een zorgvuldige commissaris in de gegeven omstandigheden gesteld kunnen worden. ${ }^{26}$ In zoverre kan worden gesteld dat het commissariaat een zekere objectieve inhoud heeft.

b) Verwijtbaarheid

Uit art. 9 volgt dat de commissaris die zijn taak onbehoorlijk vervult de

24. Ook de Rechtbank Breda (1 mei 1990 , NJ 1990, 740) lijkt in de zaak Tilburgse Hypotheekbank uit te gaan van dit standpunt (blz. 3068). Eveneens waarschijnlijk in deze zin Maeijer (1991), blz. 11.

25. In deze zin Eykman, TVVS 1986, blz. 90; Van Schilfgaarde (1986), blz. 17 en (1987), blz. 273-274.

26. In gelijke zin Huizink (1989), blz. 97 en de aldaar aangehaalde schrijvers. Zie in het algemeen over deze problematiek $E$. Schwark, Zum Haftungsmaßstab der Aufsichtsratsmitglieder einer AG, FS-Werner, 1984, blz. 841 e.v. 
daardoor ontstane schade dient te vergoeden. Het artikel vestigt deze aansprakelijkheid niet met zoveel woorden, omdat daarin slechts gesproken wordt over hoofdelijke aansprakelijkheid van commissarissen voor fouten van medecommissarissen. Echter, als de commissaris aansprakelijk is voor onbehoorlijke taakvervulling van zijn medecommissarissen dient met meer reden te worden aangenomen dat hij voor eigen tekortkomingen eveneens aansprakelijk is.

Aansprakelijkheid op grond van art. 9 is mijns inziens niet een afgeleide van het neminem laedere beginsel (art. 6:162 BW). De commissaris is jegens de vennootschap gehouden tot een behoorlijke vervulling van zijn taak, en niet enkel tot het zich onthouden van handelingen die de vennootschap kunnen schaden. De aansprakelijkheid ex art. 9 vloeit daarom voort uit de plicht om vrijwillig aangenomen verplichtingen naar behoren uit te voeren. ${ }^{27}$ In zoverre lijkt mij de opmerking van Maeijer ${ }^{28}$ dat art. 9 "tegen de achtergrond van art. 6:74 en 6:75 NBW" moet worden geplaatst, juist. Niet echter omdat zoals genoemde schrijver stelt de verhouding tussen commissaris of bestuurder met de vennootschap contractueel van aard zou zijn, maar omdat de normen van Boek 6 op de door art. 9 geregelde verhouding analogisch kunnen worden toegepast. ${ }^{29}$

Indien men deze analogie aanvaardt kan men zich afvragen of er voldoende termen zijn om voor onbehoorlijke taakvervulling een andere mate van verwijtbaarheid te hanteren dan die welke krachtens art. 6:75 voor de nakoming van verbintenissen geldt. Daar wordt uitgegaan van het beginsel dat de tekortkoming aan de schuldenaar is toe te rekenen indien zij aan diens schuld te wijten is. Een bijzondere verwijtbaarheid, in de vorm van opzet of grove schuld, is derhalve in beginsel niet vereist. Nochtans kan uit wet, rechtshandeling of in het verkeer geldende opvatting anders voortvloeien. Alvorens daar nader op in te gaan zou ik een opmerking van systematische aard willen maken.

In de literatuur wordt deze vraag behandeld in het kader van de aansprakelijkheid van bestuurders of commissarissen. Voor zover persoonlijke aansprakelijkheid als het belangrijkste rechtsgevolg van onbehoorlijk bestuur wordt beschouwd, is deze keuze verdedigbaar. Dogmatisch is zulks, naar het mij voorkomt, niet juist. De vraag of bepaalde gedragingen aan commissarissen kunnen worden toegerekend betreft de verantwoorde-

27. In zoverre correct De Groot (1993), blz. 6. Niet juist lijkt mij echter dat art. 9 "een aanvulling op, dan wel een verbijzondering van de aansprakelijkheid uit het arbeidscontract in het algemeen" geeft, zoals deze schrijver beweert.

28. (1991), blz. 4.

29. Het zij nog eens benadrukt dat hetgeen in de tekst wordt gesteld de mogelijkheid onverlet laat dat, naast de asusprakelijkheid uit onbehoorlijke taakvervulling, ook aansprakelijkheid uit onrechtmatige daad bestaanbaar is. 
lijkheid, dat wil zeggen de gehoudenheid tot behoorlijke taakvervulling, en niet de ansprakelijkheid, die het gevolg is van de constatering van onbehoorlijke taakvervulling. Strikt genomen kan niet worden gezegd dat "aansprakelijkheid ernstige verwijtbaarheid vereist". Aansprakelijkheid veronderstelt slechts onbehoorlijke taakvervulling, waarvoor, volgens de heersende leer, ennstige verwijtbaarheid vereist is..$^{30}$

Terugkerend tot de vraag waar het hier om gaat, namelijk de mate van verwijtbaarheid die nodig is voor onbehoorlijke taakvervulling, wordt in de literatuur voor zover het valt na te gaan unaniem aangenomen dat art. 9 een ernstige verwijtbaarheid vereist. Aansprakelijkheid ex art. 9 kan volgens de gangbare opvatting niet intreden voor zover sprake is van gewone schuld van de tekortschietende commissaris. Dit standpunt wordt over het algemeen gegrond op de leer van de Hoge Raad met betrekking tot de door werknemer aan werkgever toegebrachte schade in het kader van de dienstbetrekking. ${ }^{31}$ Dat deze leer geldt voor de bestuurder die tevens werknemer van de vennootschap is spreekt vanzelf voor wat betreft zijn hoedanigheid van werknemer. Dat hetzelfde zou moeten gelden voor zijn hoedanigheid van bestuurder is de stelling die moet worden bewezen. ${ }^{32}$ Bedacht moet daarbij worden dat het bij art. 9 gaat om de taakvervulling van "elke bestuurder", ongeacht dus of hij naast zijn vennootschapsrechtelijke verhouding nog anderszins in verhouding staat tot de vennootschap, en afgezien ook van het rechtskarakter van die nevenverhouding. ${ }^{33}$ Voor commissarissen van structuurvennootschappen geldt dit zo mogelijk in sterkere mate omdat zij verstoken zijn van de arbeidsrechtelijke bescherming, aangezien zij niet in een dienstbetrekkingt tot de vennootschap kunnen staan (art. 162).

Onder deze omstandigheden, en gezien voorts de hiervoor aangenomen

30. Het maken van onderscheid tussen verantwoordelijkheid en aansprakelijkheid is met name van belang daar waar aansprakelijkheid uit andere hoofde kan ontstaan dan uit onbehoorlijke takvervulling. Het onderscheid kan gevolgen hebben waar het betreft het ontslag van aansprakelijkheid. Zie hierna $\$ 17$, II,c.

31. HR 4 februari 1983, NJ 1983, 543 (Debrot) en HR 1 november 1991, NJ 1992, 32 (Van Helderen/Brabers). Uit de nauwelijks meer te overziene literatuur zie Handboek, nr. 257; Van Schilfgaarde, nr. 47; Huizink (1989), blz. 100; Van Schilfgaarde, Rechtspersonen, art. 8 (oud), aant. 4; Maeijer (1991), blz. 5; De Groot (1993), blz. 69. Zie ook Lowwensteyn, TVVS 1983, blz. 176 en Raaijmakers (1990), blz. 174.

32. Dit is eveneens op commissarissen van toepassing gezien de gelijke aard van de rechtsverhouding.

33. In zoverre is derhalve het door Eykman (TVVS 1986, biz. 91) gemaakt onderscheid tussen de bestuurder-werknemer, voor wie het criterium ernstig verwijt zou gelden, en de bestuurder-rechtspersoon, voor wie bedoeld criterium niet zou gelden, ongegrond. Zoals in de tekst Van Schilfgaarde (1986), blz. 17. 
analogie tussen de vennootschappelijke verhouding en de gewone obligatoire verhoudingen, dient bij de beantwoording van de verwijtbaarheidsvraag het uitgangspunt te zijn het algemeen beginsel van art. 6:75, en niet het bijzondere regime geldend voor arbeidsovereenkomsten. De vraag is dus of voor het bestuurderschap een van de hoofdregel afwijkende verwijtbaarheid geldt, en niet of de arbeidsrechtelijke uitzonderingsregeling, op zijn beurt, uitzondering lijdt voor de vennootschapsrechtelijke betrekking.

Zoals Van Schilfgaarde opmerkt ${ }^{34}$, geven noch de tekst noch de wetsgeschiedenis van art. 9 enige aanleiding om aan te nemen dat terzake van de verwijtbaarheid een bijzonder regime zou gelden. De oplossing moet worden gezocht, aldus terecht genoemde schrijver, in de rechtsgrond van de aansprakelijkheid. Voor het bijzondere verwijtbaarheidsregime zijn in de literatuur verschillende verklaringen gegeven. Ongegrond lijken mij in ieder geval de opvatting van Eykman ${ }^{35}$ en Van Schilfgaarde ${ }^{36}$ dat de rechtvaardiging van deze afwijking moet worden gezocht in de aard van de te verrichten werkzaamheden, namelijk continue, van tevoren in al zijn facetten niet bepaalbare arbeid. De verklaring van een afwijkend rechtsregime wordt hier in een feitelijke omstandigheid gezocht die, naar het mij voorkomt, eveneens in het kader van een andere rechtsverhouding dan de arbeidsovereenkomst zich kunnen voordoen, bijv. in het kader van een overeenkomst tot het verrichten van enkele diensten. Het feit dat de werkzaamheden van de bestuurder feitelijk gelijk zijn aan die van de werknemer rechtvaardigt op zich niet de toepassing van éénzelfde, van de hoofdregel afwijkend rechtsregime. ${ }^{37}$

Juist lijkt mij de opvatting van Van der Grinten ${ }^{38}$, dat het arbeidsvermogen van de werknemer ten dienste van de werkgever staat, van Brunner $^{39}$, dat de arbeider "on his master's business" werkzaam is, en van Huizink $^{40}$, voor wie de afwijking (ten opzichte van art. 6:75) verband houdt met de aard van de arbeidsovereenkomst en uit artt. 1639, 1639d en $1638 \mathrm{z}$, Boek 7A BW volgt, of uit de redelijkheid en billijkheid. ${ }^{41}$ In het bijzonder het feit dat de werknemer bij zijn dienstvervulling onderworpen

34. (1987), blz. 272-273.

35. TVVS 1981, blz. 91.

36. (1987), blz. 273-274.

37. Men zie in dit verband de onder $\S 7$,III gemaakte opmerkingen omtrent het ontslag van bestuurders, alwaar dezelfde feitelijke omstandigheden tot verschillende rechtsgevolgen leiden. Zie in deze zin HR 13 november 1992, NJ 1993, 265 (Levison).

38. Arbeidsovereenkomstenrecht, blz. 133.

39. Rede 1973, blz. 13.

40. (1989), blz. 99.

41. Hieraan zou moeten worden toegevoegd het per 1 januari 1992 ingevoerde art. 7A:1639da. 
is aan de zeggenschap van de werkgever rechtvaardigt dat hij niet dezelfde verantwoordelijkheid draagt die hij zou dragen indien hij op zelfstanige wijze zijn werkzaamheden zou verrichten. Maar bovendien doet zich, naar mijn mening, een omstandigheid voor die eveneens een rol speelt in de bepaling van het zwaardere verwijtbaarheidsregime en die mijns inziens niet zonder meer voor de bestuurder of commissaris geldt. Ik doel op het feit dat de in het verkeer geldende opvattingen, zoals met name door de Hoge Raad geïnterpreteerd, met zich meebrengen dat de werknemer als de in de regel zwakkere partij een bijzondere bescherming verdient. De positie van de werknemer verschilt in dit opzicht van die van de bestuurder. De rechtspolitieke overwegingen welke voor het arbeidsrecht gelden lijken mij niet transponeerbaar op het vennootschapsrecht. Dit blijkt bijvoorbeeld uit het tweede lid van art. 1639da, dat enige waarborgen bevat ten behoeve van de werknemer welke in een vennootschapsrechtelijke verhouding niet gelden.

Uit het voorgaande volgt dat hetgeen de Hoge Raad in het Debrotarrest bepaalt voor de dienstvervulling in het kader van de arbeidsovereenkomst op zich onvoldoende grond oplevert om hetzelfde aan te nemen voor de vennootschappelijke taakvervulling door bestuurders of commissarissen. Voorts zijn aan art. 9 noch aan het systeem van Boek 2 argumenten te ontlenen die een van art. 6:75 afwijkend regime rechtvaardigen. Vraag blijft in hoeverre partijen krachtens rechtshandeling of de in het verkeer geldende opvattingen het beginsel van het gemene recht opzij kunnen zetten.

Naar mijn mening bestaat tegen toepassing van exoneratieclausules terzake van onbehoorlijke taakvervulling door commissarissen (of bestuurders) geen bezwaar ${ }^{42}$ Ook hier kan worden uitgegaan van het beginsel van art. 6:75. Uitsluiting van aansprakelijkheid is gerechtvaardigd omdat de aard van de werkzaamheden en daardoor de voorzienbaarheid van mogelijke schade, de te betrachten zorg, etc. gelijk is an die van contractuele verrichtingen waarvoor art. 6:75 geldt. Maeijer is echter van mening dat contractuele uitsluiting van aansprakelijkheid niet geoorloofd is. ${ }^{43}$ Volgende deze schrijver vloeit zulks voort uit de strekking van art. 9, uit het feit dat voor onbehoorlijke taakvervulling onmiskenbare tekortkoming en ernstige verwijtbaarheid vereist is en uit de maatschappelijke positie van de bestuurder waarbij hij mede als trustee optreedt van bij de vennootschap betrokken belangen.

Naar mijn oordeel rechtvaardigen deze argumenten niet een verbod op

42. Zo ook Van Schilfgaarde (1986), blz. 76; Raaijmakers (1991), blz. 174.

43. (1991), blz. 5-6. 
exoneratie. Dat uit de strekking van art. 9 anders zou volgen dan hetgeen voor het gemene recht geldt is juist wat bewezen moet worden. Hetzelfde kan worden gezegd van de stelling dat slechts een onmiskenbare tekortkoming kennelijk onbehoorlijk bestuur in de zin van art. 9 oplevert. Dit is in ieder geval in strijd met het in art. 6:74 neergelegde beginsel dat "iedere tekortkoming" tot schadevergoeding verplicht, welk beginsel ook Maeijer als uitgangspunt aanvaardt. ${ }^{44}$ Vervolgens komt de vraag aan de orde, in hoeverre sprake dient te zijn van ernstige verwijtbaarheid. Maeijer stelt dat zulks "in de regel"4.5 het geval zal zijn omdat het nauwelijks denkbaar is dat een onmiskenbare tekortkoming zich voordoet zonder ernstige verwijtbaarheid. Dit lijkt mij ook juist, doch daarmee is niet uitgesloten dat ook gewone schuld onbehoorlijke taakvervulling zou medebrengen. Dit is wederom de vraag waar het om gaat. Om het vereiste van ernstige verwijtbaarheid te funderen kan, om de hiervoor aangegeven redenen, in ieder geval geen beroep worden gedaan op het Debrot-arrest. De verwijzing van Maeijer naar de trustee-functie van de bestuurder, tot slot, lijkt mij evenmin voldoende gegrond. De trustee zal inderdaad zorgvuldig moeten waken voor de hem toevertrouwde belangen. Ik vermag echter niet in te zien waarom de autonomie van partijen beperkt zou moeten worden, in die zin dat zij niet bevoegd moeten worden geacht om, desgewenst ten nadele van één hunner, de mate van zorg naar eigen behoeften te moduleren. Maeijer verwijst in dit verband naar de zorgplicht van de bewaarnemer. Hierover bepaalt art. 7:602: "De bewaarnemer moet bij de bewaring de zorg van een goed bewaarder in acht nemen." Naar mijn mening laat dit artikel het beginsel van art. 6:75 onverlet. Bovendien zou ik op grond van deze bepaling menen, dat de bewaarnemersrol aanleiding is om de bewaarnemer (de commissaris, de bestuurder) reeds wegens gewone schuld aansprakelijk te houden. Met deze rol lijkt het vereiste van ernstige verwijtbaarheid in strijd. Aan Maeijer moet overigens worden toegegeven dat de aard van de verhouding van bestuurders en commissarissen tot de vennootschap met zich mee brengt dat dit soort exoneratieclausules kritisch dient te worden beoordeeld. ${ }^{46}$ Aan de principiële aanvaardbaarheid ervan staat dit echter niet in de weg.

Op grond van het vorenstaande kan worden geconcludeerd dat tegen contractuele uitsluiting van aansprakelijkheid wegens onbehoorlijke taakver-

44. T.a.p., blz. 4.

45. T.a.p., blz. 5. Op blz. 6 lijkt Maeijer in meer absolute termen te spreken. Volgens hem is er steeds sprake van ernstige verwijtbaarheid.

46. Volgens Maeijer kan een beroep door de bestuurder op de exoneratieclausule in strijd zijn met de goede trouw. Dit impliceert echter de aanvaarding van de geldigheid van de clausule. 
vulling in beginsel geen bezwaar bestaat. ${ }^{47}$

Rest nog na te gaan in hoeverre het normale verwijtbaarheidsregime van art. 6:75 opzij zou kunnen worden gezet door in het verkeer geldende opvattingen. Ik zou willen aannemen dat het verkeerscriterium hoofdzakelijk bepaald wordt door de interpretatie die de jurisprudentie daaraan geeft. Geconstateerd moet echter worden dat de jurisprudentie omtrent art. 9 of diens voorgangers tamelijk beperkt is. Aan de schaarse jurisprudentie terzake zou men kunnen toevoegen de jurisprudentie omtrent persoonlijke onrechtmatige daad van bestuurders of commissarissen hetzij jegens de vennootschap, hetzij jegens anderen gepleegd. Daarbij zou ook, met de nodige zorgvuldigheid, de jurisprudentie met betrekking tot nakoming van contractuele plichten kunnen worden betrokken. In al deze uitspraken kunnen wellicht gedragsnormen worden gevonden die de behoorlijkheidsplicht van art. 9 helpen preciseren. ${ }^{48}$

Bestudering van de jurisprudentie geeft naar mijn mening onvoldoende steun aan de stelling dat onbehoorlijke taakvervulling van commissarissen (bestuurders) grove schuld vereist. Voor wat betreft de jurisprudentie terzake van onrechtmatige daad blijkt dit reeds uit het standaard arrest Mendes de Leon. ${ }^{49}$ Daarin overweegt de Hoge Raad: "dat toch een bestuurder, die tegen beter weten in, althans beter moetende weten, een geheel scheeve voorstelling geeft van den staat van zaken in de door hem bestuurde N.V., en daardoor een derde beweegt om daarin à pari aandelen te nemen, die ten hoogste $15 \%$ waard waren, eene handeling verricht, die de wet als onrechtmatig stempelt en dit wèl, onverschillig of hij handelt ten eigen behoeve dan wel voor anderen of zelfs als "orgaan" van een rechtspersoon; (...) dat hetgeen voor bestuurders eener N.V. ten deze geldt ook geldt voor commissarissen, al handelen deze als zoodanig en binnen de grenzen hunner bevoegdheden." Hoewel aan de gepleegde gedraging wellicht grove schuld ten grondslag ligt (gesproken wordt immers over het geven van een "geheel scheeve voorstelling") is dit in de gedachtengang van de Hoge Raad, als ik het goed zie, niet doorslaggevend. De ratio decidendi van het arrest is dat het feit dat een orgaanlid in kwaliteit handelt niet belet dat de handelende persoon tevens persoonlijk een onrechtmatige daad begaat. Het arrest kan daarom niet worden gelezen als zou daarin een

47. Een andere vraag betreft de onvang van de exoneratie. Hiervoor verwijs ik eveneens naar de problematiek van de decharge.

48. Zie voor een overzicht van de jurisprudentie inzake bestuurdersaansprakelijkheid, Timmerman, TVVS 1991, blz. 197 e.v.

49. HR 27 november 1927, NJ 1928, blz. 364 . 


\section{TAAKVERVULLING EN AANSPRAKELIJKHEID}

bepaalde mate van verwijtbaarheid vereist worden..$^{50}$ Bovendien merkt de Hoge Raad op, dat in ieder geval bestuurders "beter hadden moeten weten". Hiermee wordt de gewrakkte gedraging geobjectiveerd en daardoor in het domein van de normale aansprakelijkheid gebracht, waarin gewone schuld voldoende is.

De jurisprudentie kent gevallen van onbehoorlijke taakvervulling of onrechtmatige daad waarin waarschijnlijk sprake is van grove schuld. De mate van verwijtbaarheid is daarbij echter niet de inzet van de procedure. Grove schuld kan in deze gevallen worden aangenomen omdat er sprake is van aperte onrechtmatigheid. ${ }^{51}$ Daaruit kan men echter niet concluderen dat de rechter het bestaan van ernstige verwijtbaarheid als voorwaarde voor aansprakelijkheid stelt. De jurisprudentie geeft ook voorbeelden van gevallen waarbij gewone schuld voldoende wordt geacht. ${ }^{52}$ Het lijkt mij

50. Gesteld zou kunnen worden dat deze overwegingen betrekking hebben op de aansprakelijkheid ex art. 6:162, zodat daaraan geen criteria kunnen worden ontleend voor de onbehoorlijke taakvervulling. Dit lijkt mij maar ten dele juist. De overtreden norm is weliswaar een andere, maar de onrechtmatige daad wordt in de kwaliteit van commissaris gepleegd. In zoverre kan worden aangenomen dat de gehanteerde maatstaven ook bruikbaar zijn in het kader van de taakvervulling ex art. 9.

51. Zie bijv. Hof Arnhem 29 april 1936, NJ 1936, 793, "dat het Hof het simpele feit [mijn curs. JMBF] van op een willekeurige dag (...) zonder eenige waarschuwing van Commissarissen de fabriek te sluiten en het bedrijf stil te leggen, een dermate ernstig en onverantwoord feit acht, dat daardoor alle vertrouwen in de gestie van de directie teloor gaat"; Rb. Haarlem 30 december 1941, NJ 1942, 798, "dat gedaagde (...) eischeresse desbewust en rechtstreeks (...) heeft benadeeld en aldus grovelijk in strijd heeft gehandeld met de ingevolge art. $45 \mathrm{k}$ (oud) en art. 1630d BW op hem rustende verplichtingen"; Hof 's-Gravenhage 13 april 1942, NJ 1942, 529 "dat een directeur, die onder al de genoemde omstandigheden en met het aangewezen oogmerk het faillissement zijner vennootschap aanvraagt, grove en in geen enkel opzicht (...) te verontschuldigen wanprestatie pleegt ten aanzien van zijn verplichting om de hem opgedragen taak behoorlijk en naar zijn beste vermogen te vervullen"; Rb Amsterdam 27 mei 1981, NJ 1985, 124 "dat (...) onvoldoende zorg is betracht ten aanzien van het verhaal van alle crediteuren van deze vennootschap en het daarbij met name de belangen van de Commissie en Wilkes op aanvaardbare wijze zijn veronachtzaamd [mijn curs. JMBF], zodat sprake is van een onrechtmatige daad gepleegd door de gedaagden als directeuren c.q. commissaris". Vgl. voorts HR 11 maart 1937. NJ 1937, 899; Rb. Utrecht 24 februari 1943, NJ 1943, 862; Arb. 12 februari 1944, AR 1944, 304; HR 14 mei 1948, NJ 1948, 458 en Rb. Dordrecht 28 april 1988, KG 1988, 228.

52. Rb 's-Hertogenbosch 5 december 1941, NJ 1942, 432, "dat mitsdien N., door gelden der eischeres [de vennootschap, JMBF] tot vermeld doel aan te wenden, jegens haar onrechtmatig heeft gehandeld en ansprakelijk is geworden voor de deswege door haar geleden schade"; Hof 's-Gravenhage 12 januari 1972, NJ 1972,

(Wordt vervolgd...) 


\section{VERWIJTBAARHEID}

dan ook dat niet gesteld kan worden dat de jurisprudentie steun geeft aan de opvatting, dat krachtens in het verkeer geldende opvatting onbehoorlijke taakvervulling door commissarissen (bestuurders) op grond van art. 9 opzet of grove schuld van de zich onbehoorlijk gedragende persoon veronderstelt. $^{53}$

Uit hetgeen hiervoor gezegd is volgt dat art. 9 geen afwijkend regime bevat ten opzichte van de nakomingsregels van het gemene recht (artt. 6:74 en 6:75 BW). Onbehoorlijke taakvervulling kan zich derhalve voordoen wanneer aan het betrokken orgaanlid geen ernstig verwijt kan worden gemaakt, maar slechts gewone schuld kan worden verweten. ${ }^{54}$

\section{Aansprakelijkheid jegens de vennootschapsboedel in geval van faillissement}

Krachtens art. 138 jo. 149 is iedere commissaris in geval van faillissement

52.(...vervolg)

221 "noch de omstandigheid, dat Goede als orgaan van de vennootschap heeft gehandeld noch de mening die hij had en heeft over de betamelijkheid van zijn optreden, zijn aansprakelijkheid tegenover Vlaardingen-Oost [een contractspartij, JMFB] uitsluit". Vgl. verder HR 20 mei 1924, NJ 1924, blz. 1107; HR 31 januari 1958, NJ 1958, 251; Rb. Breda 31 januari 1984 de NV 63 (1985), blz. 31 -voor zover uit de sumiere weergave van de feiten valt te concluderen- en HR 6 oktober 1989, NJ 1990, NJ 1990, 286 (Beklamel).

53. Ik heb me nog afgevraagd in hoeverre het unanieme standpunt in de doctrine, dat grove schuld vereist is, zou kunnen duiden op het bestaan van een verkeersopvatting in die richting. De overtuigingskracht van dat standpunt staat of valt uiteraard met de gegrondheid van de argumenten die daarvoor worden aangedragen. Zoals wij gezien hebben, is het voornaamste argument het beroep op het Debrot-criterium, welk criterium naar mijn mening niet van toepassing is op de vennootschapsrechtelijke verhouding. Ik ben daarom geneigd om te denken dat de heersende opvatting onvoldoende gegrond is. Aan deze opvatting kan daarom rechtens slechts beperkte waarde worden gehecht.

54. Gesteld zou kunnen worden dat het aansprakelijk stellen van commissarissen (bestuurders) voor zuiver culpoos handelen tot onbillijke resultaten zou kunnen leiden wanneer de daardoor veroorzaakte schade in financieel opzicht in geen verhouding zou staan met de onbehoorlijke taakvervulling. Met name bij vennootschappen van enige omvang is het inderdaad mogelijk dat overtreding van art. 9 tot aanzienlijke schade leidt. Het ware onredelijk bestuurders en commissarissen daarvoor aansprakelijk te stellen. Op zich is dit echter een probleem dat los staat van de (mate van) verwijtbaarheid van de onbehoorlijke taakvervulling. Het betreft hier de omvang van de schadevergoedingsplicht, waarvoor -uitgaande van het bestaan van causaal verband tussen onbehoorlijke taakvervulling en schade- art. 6:98 uitkomst kan bieden. 
van de vennootschap hoofdelijk aansprakelijk jegens de boedel voor het tekort indien de raad van commissarissen zijn taak kennelijk onbehoorlijk heeft vervuld en aannemelijk is dat dit een belangrijke oorzaak is van het faillissement. Deze aansprakelijkheidsnorm beoogt de belangen van de crediteuren van de vennootschap te beschermen.

Aandacht verdient in de eerste plaats de grondslag van deze aansprakelijkheid.

a) Grondslag van de aansprakelijkheid ex art. 138

In de literatuur worden hieromtrent twee standpunten ingenomen. Volgens enkele schrijvers is de aansprakelijkheid ex art. 138 een vorm van externe aansprakelijkheid. ${ }^{55}$ Commissarissen zijn niet jegens de rechtspersoon doch jegens schuldeisers aansprakelijk. Aangezien tussen commissarissen en schuldeisers van de rechtspersoon geen contractuele verhouding bestaat, kan worden aangenomen dat i.c. sprake is van een vorm van delictuele aansprakelijkheid. In deze visie is de norm van art. 138 een lex specialis van art. 6:162.56

Volgens de tweede opvatting is de aansprakelijkheid ex art. 138 een vorm van interne aansprakelijkheid. Commissarissen zijn jegens de vennootschap(sboedel), en niet jegens de schuldeisers, aansprakelijk. ${ }^{57}$

Mijns inziens gaat het wettelijk systeem er van uit dat de aansprakelijkheid van commissarissen ex art. 138 er éen is jegens de vennootschap en niet jegens de crediteuren. Ik zou dit als volgt willen adstrueren. ${ }^{58}$ Zoals gezegd, bestaat tussen commissarissen en schuldeisers van de vennootschap niet een rechtsverhouding. Commissarissen staan tot de rechtspersoon in een vennootschapsrechtelijke verhouding op grond waarvan zij gehouden zijn tot een behoorlijke taakvervulling. Deze verhouding verplicht commissarissen niet om de rechtspersoon in staat te stellen aan zijn schulden te voldoen. $\mathrm{Zij}$ zijn echter wel gehouden tot het houden van

55. Zie onder andere Van Schilfgaarde (1986), blz, 16; De Groot, NJB 1986, blz. 1307; Huizink (1989), blz. 110 en Maeijer (1991), blz. 12.

56. Met zoveel woorden De Groot (1993), blz. 46 en Maeijer, t.a.p. Zie ook in gelijke zin de bijdrage van laatstgenoemde auteur in de Ronse-bundel, 1986, blz. 284.

57. Dit is de visie van Lowensteyn, TVVS 1983, blz. 175 en Van der Grinten, Handboek nr. 399.1 en De NV 64 (1986), blz. 21.

58. Parlementaire stukken hebben reeds op zich betrekkelijke waarde. Naar mijn mening geldt dit in nog sterkere mate voor een even politiek gevoelig als recblstechnisch complex onderwerp als het hier aan de orde zijnde. Aan de uitgebreide en onoverzichtelijke wetsgeschiedenis van de misbruikwetten zijn overigens argumenten voor beide in de tekst genoende opvattingen te ontlenen. Op dit punt wil ik dan ook afzien van de gebruikelijke exegese van de parlementaire stukken. 
een dusdanig toezicht op het beleid van het bestuur dat wanprestatie van de vennootschap zoveel mogelijk voorkomen wordt. Onder extreme omstandigheden kan de toezichthoudende activiteit van commissarissen dermate gebrekkig zijn dat zij tot het faillissement van de vennootschap leidt. De belangen van de vennootschapscrediteuren worden benadeeld in zoverre hun vorderingen niet, of slechts gedeeltelijk, kunnen worden voldaan. Het kan niet worden ontkend dat in dit geval de schade van de crediteuren mede veroorzaakt is door het onbehoorlijk handelen van de commissarissen. Het enkele feit dat de schade zijn oorzaak vindt in dit handelen, is echter onvoldoende grond om te stellen dat de commissarissen gehouden zijn tot vergoeding van deze schade. ${ }^{59}$ Een eventuele schadevergoedingsplicht vereist dat commissarissen door hun handelen een rechtsplicht hebben geschonden die hen jegens de schuldeisers van de rechtspersoon bindt. $^{60}$

Men zou wel kunnen stellen dat, in zoverre art. 138 de belangen van de schuldeisers beschermt, dit artikel aan commissarissen een rechtsplicht oplegt jegens de crediteuren van de vennootschap. Als ik het goed zie, is dit de gedachte die ten grondslag ligt aan het fraaie betoog van Van Schilfgaarde. In het kader van een overweging over kapitaalbescherming schrijft hij: "Van vermogensafzondering naar kapitaalsvorming. Bij de contractuele opvatting past een beschouwingswijze waarin het accent ligt op vermogensafzondering als een vorm van risicobeperking voor de ondernemende aandeelhouders. Niet goed is in te zien waarom de aandeelhouders met het aldus afgezonderde vermogen niet zouden mogen doen wat zij willen. Pas wanneer de gedachte doordringt dat het gaat om kapitaalvorming ten behoeve van de NV als een van de aandeelhouders vrijstaand instituut, kan de gedachte aan kapitaalbescherming, waarbij het uiteindelijk gaat om bescherming van de crediteuren, vaste voet krijgen." En verderop: "Heel duidelijk is het verband tussen de institutionele opvatting en (...)

59. Het lijkt mij dat dit door Boukema (1992), blz. 41, wordt onderkend wanneer hij schrijft: "De bestuurders zijn bij kennelijk onbehoorlijk bestuur krachtens artikel 2:138 (...) niet aansprakelijk voor schade, maar voor de schulden van de vennootschap die niet zijn voldaan" (mijn curs). Hij is van mening dat, gezien het feit dat de curator ten behoeve van de crediteuren optreedt, art. 138 een aansprakelijkheid jegens crediteuren vestigt. Mijns inziens ziet hij daarbij echter over het hoofd dat de wet commissarissen (bestuurders) jegens de boedel aansprakelijk stelt.

60. Commissarissen kunnen in de uitoefening van hun taak, onrechtmatig handelen jegens de schuldeisers van de rechtspersoon. De rechtsgrond voor deze vorm van aansprakelijkheid is de schending van art. 6:162. Zie HR 25 november 1927, NJ 1928, blz. 829 (Mendes de Leon). Voor deze vorm van onrechtmatigheid is het echter niet van belang dat tussen crediteuren en vennootschap een obligatoire verhouding bestaat, hetgeen voor de toepassing van art. 138 wel noodzakelijk is. 
bestuurdersaansprakelijkheid." ${ }^{\text {61 }}$ Deze visie kan wellicht verklaren welke motieven de wetgever bewegen tot regeling inzake kapitaalbescherming c.q. verscherpte aansprakelijkheid van bestuurders en commissarissen. Wanneer echter daaruit geconcludeerd zou worden dat tussen laatstgenoemden en crediteuren van de vennootschap een rechtsband bestaat, zou deze visie tot een onaanvaardbaar wegdenken van de rechtspersoon leiden dat noch met de tekst noch met het systeem van de wet te rijmen is. Commissarissen zijn immers volgens art. 138 lid 1 "jegens de boedel" aansprakelijk. De aansprakelijkheid bestaat jegens de in staat van faillissement verkerende vennootschap. Commissarissen zijn voorts aansprakelijk wegens "kennelijk onbehoorlijke taakvervulling", hetgeen wil zeggen dat zij geen of onvoldoende toezicht hebben gehouden op het beleid van het bestuur en op de algemene gang van zaken in de vennootschap. Dat commissarissen bij hun taakuitoefening, om de fraseologie van art. 140 te gebruiken ${ }^{62}$, rekening moeten houden met de belangen van schuldeisers en van andere "institutioneel betrokkenen", oftewel met de belangen van de met de vennootschap verbonden onderneming, doet niet een rechtsplicht jegens hen ontstaan bij schending waarvan, onder de voorwaarden van art. 138, de gehoudenheid tot schadevergoeding zou volgen. De enige in dit kader relevante verhouding is naar mijn mening die tussen commissaris en vennootschap, welke verhouding de commissaris tot een behoorlijke taakuitoefening jegens de vennootschap verplicht. Het spreekt vanzelf dat wanneer commissarissen de vennootschap tot het faillissement hebben geleid zij veroordeeld worden tot aanvulling van het vermogen van de vennootschap. Zulks niet omdat zij jegens de crediteuren onrechtmatig hebben gehandeld, doch omdat zij ten nadele van de crediteuren hebben bijgedragen tot de aantasting van het vermogen van de rechtspersoon. ${ }^{63}$

Men kan dit ook anders uitdrukken. Art. 138 beoogt de belangen van schuldeisers van de vennootschap te beschermen. Doch deze bescherming verloopt via (het vermogen van) de rechtspersoon. Commissarissen handelen onrechtmatig omdat het verhaalsobject van de crediteuren, namelijk het vermogen van de vennootschap, door hun onbehoorlijke taakvervulling wordt aangetast. Strikt genomen rust op hen geen verplichting tot instandhouding van dat vermogen want, ware dit het geval, dan zouden commissarissen telkens aansprakelijk zijn wanneer het vennootschapsvermogen onvoldoende verhaal zou bieden voor de schulden van de vennootschap. Commissarissen zijn jegens de vennootschap slechts tot een behoorlijke taakuitoefening gehouden. Schending van deze verplichting leidt tot aanvul-

61. Vennootschapsrecht na 27 jaren, Slagter-bundel, 1988, blz. 258-259.

62. Zie $\S 1$,II hiervóor.

63. Evenzo Lowensteyn, TVVS 1983, blz. 175, noot 11. 
ling van het in de boedel ontstane tekort, welke betaling niet aan de schuldeisers doch aan de boedel geschiedt.

Dit brengt ons tot een ander argument dat wordt aangevoerd ter ondersteuning van de stelling dat art. 138 een geval van externe aansprakelijkheid betreft.

De vordering krachtens dit artikel wordt door de curator ingesteld. Deze treedt niet op als vertegenwoordiger van de vennootschap maar, in de woorden van Van Schilfgaarde, als "belangenvertegenwoordiger" van de crediteuren. ${ }^{64}$ Dat de curator de vordering in het belang van de schuldeisers instelt lijkt mij op zich juist. De vordering is immers gericht tot aanzuivering van het tekort van de boedel, dat op zijn beurt als verhaalsobject voor de crediteuren dient. Dit wil echter niet zeggen dat de curator daarom als vertegenwoordiger van de crediteuren, in de uitoefening van hun rechten, optreedt. Zoals Wachter in zijn noot onder het Peeters/Gatzen-arrest stelt: "De juridische positie van de faillissementscurator is een voor misverstand vatbare". Dit omdat hij zowel rechten van de failliet als rechten jegens de failliet uitoefent. ${ }^{65}$ Het kan niet zonder meer worden gesteld dat de curator als vertegenwoordiger van de failliet optreedt. Waarschijnlijk moet deze kwestie niet als vertegenwoordigingsprobleem worden benaderd. Het faillissement brengt voor de failliet het verlies van de beschikkingsbevoegdheid over zijn vermogen mee (art. $23 \mathrm{Fw}$ ). De daartoe behorende rechten dienen door de curator te worden uitgeoefend. Zoals de wet stelt, "de curator is belast met het beheer en de vereffening van den faillieten boedel" (art. 68 lid $1 \mathrm{Fw}$ ). Het feit dat hij rechten van de failliet uitoefent betekent echter niet dat hij diens vertegenwoordiger is, dat wil zeggen: dat hij namens de failliet rechtshandelingen verricht die aan deze laatste worden toegerekend. ${ }^{66}$ De curator oefent in eigen naam krachtens de wet rechten van de failliet uit, waarbij de rechtsgevolgen ten laste van

64. (1986), nrs. 8 en 47-49. Over de positie van de faillissementscurator volgens deze schrijver zie men verder diens noot onder HR 14 januari 1983, NJ 1983, 597 (Peeters/Gatzen), AA 1984, blz. 220 e.v. Schoordijk (1984), blz. 531, beschouwt de curator als vertegenwoordiger van de schuldeisers.

65. Zie bijv. artt. 68 lid 1 en 177 Fw.

66. Over deze materie, met name over het onderscheid tussen vertegenwoordigen en beschikken over andermans recht, vgl. $L$. Groefsema, Bevoegd beschikken over andermans recht, diss. Groningen 1993, blz. 40 e.v. Deze schrijver verwerpt ook de vertegenwoordigingsconstructie bij het handelen van de curator (t.a.p., blz. 155). Laatstelijk ook Kortmann (1993), blz. 111.

Het komt mij voor dat deze problematiek in dezelfde lijn ligt als de action directe c.q. action oblique, waarbij onder bepaalde omstandigheden in eigen naam andermans rechten worden uitgeoefend, zo bijv. artt. 1840 lid 3 Oud BW en 7:411, 412 BW. Zie over deze kwestie de noot van Wachter onder HR 31 mei 1974, NJ 1976, 309 (ACB/Dieleman). 
het vermogen van laatstgenoemde worden gebracht. ${ }^{67}$ Voorts volgt ook uit de tekst van art. 138 lid 1 dat het vorderingsrecht ex art. 138 an de vennootschap toekomt, en dat de curator derhalve een rechtsvordering van de rechtspersoon uitoefent. De bepaling rept immers over aansprakelijkheid "voor het bedrag van de schulden voor zover deze niet door vereffening van de overige baten kunnen worden voldaan." Hierover merkt Van Schilfgaarde op: "De bepaling spreekt van 'overige' baten omdat de vordering op de bestuurders zelf een bate is. ${ }^{68}$ Dit lijkt mij juist. Maar dan dient de vordering als één van de baten van de vennootschap te worden beschouwd. Het is, met andere woorden, haar vordering.

Als dit zo is, en gezien het feit dat de verplichting tot behoorlijke taakvervulling de commissaris jegens de vennootschap en niet jegens de crediteuren bindt, is de conclusie dat de schending van de verplichting tot behoorlijke taakvervulling aan de vennootschap, en niet aan de crediteuren, een recht jegens commissarissen geeft. De aansprakelijkheid ex art. 138 is derhalve een vorm van interne aansprakelijkheid. Een aansprakelijkheid dus jegens de vennootschap(sboedel) en niet jegens de crediteuren van de vennootschap.

Hoe verhoudt zich de zojuist verdedigde stelling tot het zesde lid van dat artikel, dat verleende décharge niet in de weg staat aan instelling van de vordering? Verdedigd zou immers kunnen worden dat, nu de rechtspersoon commissarissen gedéchargeerd heeft voor het gehouden toezicht dezen niet wegens onbehoorlijke taakvervulling door dezelfde vennootschap aangesproken kunnen worden.

Het lijkt mij dat om deze vraag te beantwoorden nader moet woorden ingegaan op de problematiek van de décharge.

Décharge kan worden gedefinieerd als de handeling waarbij de rechtspersoon de uitoefening van zekere bevoegdheden door een orgaan(lid) gedurende een bepaalde periode goedkeurt. Het rechtsgevolg van de décharge is dat de rechtspersoon jegens de gedéchargeerde afstand doet van zijn aanspraken wegens mogelijke onbehoorlijke taakvervulling. Voor zover persoonlijke aansprakelijkheid het gevolg kan zijn van onbehoorlijke taakvervulling, betekent décharge ook ontslag van aansprakelijkheid. ${ }^{69}$

67. Als ik het goed zie verklaart dit ook waarom de vordering ex art. 138 niet vatbaar is voor cessie (HR 7 september 1990, NJ 1991, 52). De curator kan het vorderingsrecht niet cederen omdat hij terzake van die overdracht beschikkingsonbevoegd is (art. 3:84, lid 1). Het recht komt immers de vennootschap toe. Anderzijds kan de rechtsvordering niet los van het vorderingsrecht worden overgedragen (art. 3:304).

68. (1986), blz. 51 .

69. In deze zin ook Van Schilfgaarde (1992), nr. 111. 
Doch aansprakelijkheid behoeft niet het enige gevolg van onbehoorlijke taakvervulling te zijn. Het is zelfs geen noodzakelijk gevolg. Onbehoorlijke taakvervulling kan voor de zich onbehoorlijk gedragende persoon andere gevolgen met zich mee brengen. Ook deze gevolgen worden door de décharge in beginsel afgewend. In zoverre houdt décharge meer in dan de enkele uitsluiting van aansprakelijkheid van de gedéchargeerde.

Décharge betreft de taakvervulling door de commissaris, en werkt derhalve in zijn verhouding tot de rechtspersoon. Hieruit volgt dat het een zuiver interne aangelegenheid van de vennootschap betreft. Dit blijkt ook uit de tekst van de wet, alwaar gesteld wordt dat de bestuurder (commissaris) "tegenover de rechtspersoon" tot een behoorlijke taakvervulling gehouden is. ${ }^{70}$ Décharge kan daarom derden, die geen partij zijn bij de verhouding, baten noch schaden. Het is voor hen res inter alios acta. ${ }^{11}$

De hier verdedigde visie, aanvaard door de Hoge Raad en door de meeste schrijvers, wordt bestreden door Bartman ${ }^{72}$ en Slagter. ${ }^{73}$ Als ik het goed zie, komt het bezwaar van genoemde auteurs hierop neer, dat zij zich niet kunnen verenigen met het feit dat een bestuurder (commissaris), die zich schuldig maakt aan onbehoorlijke taakvervulling, niet aansprakelijk kan worden gesteld voor schade die een gevolg is van zijn onbehoorlijk handelen jegens de rechtspersoon. In hun visie klemt dit temeer waar het betreft schade die veroorzaakt is door opzet van de zich onbehoorlijk gedragende bestuurder (commissaris).

Het komt mij voor dat deze kwestie een diepere betekenis heeft dan het enkel vaststellen wie de vordering ex art. 9 kan instellen. Waar het mijns inziens hier om gaat is vast te stellen wie, en waarom, de zich onbehoorlijk gedragende commissaris (bestuurder) kan ontslaan van de gevolgen welke verbonden zijn aan schending van art. 9, met name de gehoudenheid tot vergoeding van veroorzaakte schade. De diepere betekenis van de kwestie schuilt mijns inziens hierin dat door de gestelde vraag te

70. In gelijke zin Van Schilfgaarde, WPNR 5958 (1990), blz, 273.

71. Evenzo Grosheide, De NV 32 (1954-55), blz. 82 Van der Grinten, De NV 65 (1987), blz. 102. De Hoge Raad overweegt in het Ellem-arrest (HR 20 oktober 1989, NJ 1989, 308, r.0. 3.4) :"Het gaat in deze zaak (...) om een vordering van de vennootschap zelf ter zake van het beheer van De Bruin. "De door mij gecursiveerde woorden moeten mijns inziens niet aldus worden verstaan dat ons hoogste rechtscollege de aangehaalde overweging tot het betrokken geval zou willen beperken en dat derhalve in andere gevallen het wel mogelijk zou zijn dat décharge de rechten van derden zou raken. Naar mijn mening doet de Hoge Raad hier zijn uitspraak pars pro toto.

72. WPNR $5958 / 5959$ (1990).

73. TVVS 1991, blz. 188-189. Ik versta de kritiek van Slagter aldus dat hij bezwaren heeft tegen de geldende regeling. Voor zover zijn opmerkingen de iure constituendo zijn, zal ik daaraan voorbij gaan. 
beantwoorden aangegeven wordt wie de ultieme zeggenschap heeft over het vermogen van de vennootschap. Aldus komt ook hier de problematiek van het zogenaamde vennootschappelijk belang naar voren. Het eenvoudigst kan de kwestie worden opgelost door te stellen dat de rechtspersoon zelf déchargeert en dat hij daartoe gerechtigd is omdat bij décharge zijn eigen vermogen betrokken is. Evenals ieder bevoegd rechtssubject, is de rechtspersoon gerechtigd om afstand te doen van aanspraken jegens degenen die aan zijn vermogen schade hebben toegebracht, zelfs wanneer de beschadiging opzettelijk is geschied. Dit is het standpunt van A-G Hartkamp in zijn conclusie voor het Ellem-arrest wanneer hij overweegt: "Bij de verlening van décharge handelt de algemene vergadering van aandeelhouders als orgaan van de vennootschap. Anders gezegd: de vennootschap handelt zelf, vertegenwoordigd door de algemene vergadering" (mijn curs.).

Dit standpunt zou ik ook willen innemen. ${ }^{74}$ Naar mijn mening heeft de déchargerende wil van de ava te gelden als de wil van de vennootschap omdat deze om des aandeelhouders wille bestaat. De vennootschap dient het belang van de aandeelhouders en in zoverre is het gerechtvaardigd dat de ava namens de vennootschap afstand kan doen van eventuele schade-

74. De verklaring van A-G Harkamp, die sporen vertoont van de orgaan-theorie, zou ik echter niet geheel willen onderschrijuen. Deze verklaring is vanuit het positief recht afdoende omdat indien de ava volgens de wet bevoegd is om te déchargeren, de vennootschap gebonden is aan een bevoegd verleende décharge. Hiertegen kunnen niettemin tweeërlei bezwaren worden aangevoerd. De déchargerende wil van de vennootschap heeft onder bepaalde omstandigheden niet het beoogde gevolg. Het valt dan niet in te zien waarom, indien het de vennootschap zelf is die handelt, onder die omstandigheden geen décharge ontstaat. Hartkamp stelt: "Er moet een goede reden zijn om de vennootschappelijke structuur als het ware opzij te schuiven en de vennootschap het recht te geven om haar eigen (ex-)aandeelhouder aan te spreken en op haar eigen handeling terug te komen" (mijn curs.). Van een dergelijk "terugkomen op de eigen handeling" noch van een "opzij schuiven van de vennootschappelijke structuur", behoeft mijns inziens sprake te zijn. Indien aan décharge onder omstandigheden geen werking toekomt, geschiedt zulks omdat de wilsverklaring van de algemene vergadering niet aan de vennootschap kan worden toegerekend, bijv. omdat aan de totstandkoming van het besluit gebreken kleven. Alsdan is de vennootschap ook niet gebonden aan het betrokken décharge-besluit en blijft de "vennootschappelijke structuur" intact. Hiermee is tevens het tweede bezwaar tegen de verklaring van de A-G gegeven. Immers, niet wordt verklaard waarom de wil tot décharge van de algemene vergadering aan de vennootschap wordt toegerekend. Dit bezwaar is overigens van beperkte strekking en, in het kader van de conclusie van de A-G, zelfs irrelevant en wel vanwege het feit dat het voldoende is dat het positieve recht de décharge-bevoegdheid bij de algemene vergadering legt. Waarom de wilsverklaring van de algemene vergadering déchargerende werking heeft, behoeft vanuit dat perspectief geen nadere uitleg. Anders is de situatie in dogmatisch opzicht. Dogmatisch bezien dringt zich de vraag naar het motief van de toerekening wel op. 
vergoedingsaanspraken ex art. 9. Hiermee zijn tevens de grenzen aangegeven waarbinnen toerekening mogelijk is, namelijk de grenzen die wet en statuten markeren voor de geldigheid van besluiten (artt. 14 en 15). Echter, niet gezegd is dat anderen dan aandeelhouders geen belang zouden kunnen hebben bij instandhouding van het vermogen van de vennootschap, waarbij met name aan schuldeisers moet worden gedacht. Het enkele feit echter dat zij dat belang hebben, geeft hen geen beslissingsmacht binnen de rechtspersoon en met name niet over diens vermogen. Bartman oordeelt hierover kennelijk anders wanneer hij schrijft: "De norm van art. 8 Boek 2 BW [thans art. 9] strekt immers tevens tot bescherming van de belangen van (o.a.) schuldeisers der vennootschap, zijnde in hoge mate betrokken bij de vennootschap en de met haar verbonden onderneming. "75 Belang is echter geen gerechtigdheid. De vennootschappelijke bescherming van het belang van crediteuren binnen de vennootschap loopt in het systeem van de wet niet via art 9, doch via de toezichthoudende taak van de raad van commissarissen, welk orgaan ervoor moet zorgen dat het beleid van het bestuur niet leidt tot ongerechtvaardigde benadeling van de schuldeisers. Het belang van crediteuren wordt voorts beschermd door middel van hun vorderingsrecht jegens de vennootschap. Daarnaast, en voor zover de zorgvuldigheidsnorm van art. 6:162 geschonden is, kunnen crediteuren aanspraak maken op de bescherming uit onrechtmatige daad. ${ }^{76}$ Dat de pleger van de onrechtmatige daad in zijn hoedanigheid van orgaan van de rechtspersoon handelt is in dit opzicht irrelevant. ${ }^{77}$ Evenzeer is het irrelevant dat de onrechtmatig handelende persoon tevens art. 9 heeft geschonden en de vennootschap hem voor de gevolgen van deze schending heeft ontslagen. ${ }^{78}$

75. Curs. ook in het origineel, WPNR 5958 (1990), blz. 272. Anders dan Bartman, Van Schilfgaarde, in het naschrift op Bartman's artikel en Raaijmakers, (1991), blz. 169.

76. Hierbij moet worden bedacht dat het in deze kwestie niet zozeer gaat om het feit dat de rechtsorde voldoende voorzieningen ter beschikking stelt ter bescherming van de belangen van crediteuren (zo echter Maeijer in zijn noot onder het Ellemarrest, met een beroep op zijn rede in NV 67 (1989), blz. 3), maar om de rechtsgrond waarop bedoelde voorzieningen berusten. Bij analyse van die rechtsgronden mot de conclusie zijn dat de crediteuren aan art. 9 geen aanspraak kunnen ontlenen, en daarom gebaat noch geschaad worden door een déchargeverlening.

77. Zo ook HR 25 november 1927, NJ 1928, blz. 364 (Mendes de Leon) en 11 maart 1937, NJ 1937, 899.

78. Décharge kan ook nadelige gevolgen hebben voor de werknemers in dienst van een eenmans-BV. Mijns inziens is het enkele feit dat de werknemers door het déchargebesluit worden benadeeld onvoldoende grond om te stellen dat het besluit of een beroep daarop van de gedéchargeerde persoon onrechtmatig zouden zijn. Enig verschil tussen de werknemers en de andere crediteuren vermag ik in dit opzicht niet in te zien. Anders Maeijer in zijn noot onder het Ellem-arrest. 
Keren wij thans terug op de gestelde vraag, namelijk de doorbreking van de décharge door de vordering ex art. 138.

Het feit dat de verleende décharge slechts intern werkt -dit wil zeggen niet ten detrimente van de crediteuren- vindt volgens Raaijmakers ${ }^{79}$ zijn verklaring in de omstandigheid dat de aansprakelijkheid ex art. 138 zwaarder is dan de aansprakelijkheid van art. 9. Hierbij past dat het subjectieve oordeel van het déchargerende orgaan op grond van art. 9 bij toepasselijkheid van art. 138 vervangen wordt door het objectieve oordeel van de rechter. Ik zou echter menen dat de enkele verzwaring van de aansprakelijkheid niet kan leiden tot het ontnemen van de werking aan een ontslag van aansprakelijkheid dat, zoals wij gezien hebben, ook kan worden verleend terzake van opzettelijk toegebrachte schade. Indien décharge rechtsgeldig kan worden verleend voor dit soort schade is het niet in te zien hoe een "verzwaarde" aansprakelijkheid aan zulk een décharge -die overigens in art. 9 dezelfde takvervulling tot onderwerp heeft als in art. 138zijn werking zou kunnen ontnemen.

Mijns inziens moet de oplossing van deze problematiek niet in de vorm van de aansprakelijkheid worden gezocht maar in de grenzen van de décharge zelf. Hiervoor is reeds gesteld dat voor anderen dan de bij de rechtshandeling betrokken partijen de décharge als res inter alios acta is te beschouwen. Crediteuren van de vennootschap kunnen geen schade ondervinden van een ontslag van aansprakelijkheid. De déchargerende bevoegdheid van de vennootschap bestrijkt slechts schade die aan haar is toegebracht. De vennootschap kan afstand doen van haar verhaal op degenen die haar vermogen hebben benadeeld. Maar de déchargerende wil van de vennootschap kan niet zo ver reiken dat het ontslag ten nadele van haar crediteuren werkt. Gesteld zou kunnen worden dat, aangezien het vennootschapsvermogen mede tot voldoening van de vennootschapsschulden strekt, de rechtspersoon het verhaal van zijn crediteuren niet kan frustreren zonder hun instemming. De eenzijdige afstanddoening door de vennootschap kan daarom aan haar crediteuren niet tegengeworpen worden. Bij faillissement van de vennootschap verandert de rechtsverhouding tussen vennootschap en commissarissen, voor wat betreft hun aansprakelijkheid terzake van onbehoorlijke taakvervulling, niet. Alleen, de verleende décharge is slechts doeltreffend voorzover het vennootschapsvermogen toereikend is om de vennootschapsschulden te voldoen. Voor zover het vermogen door toedoen van commissarissen ten nadele van de schuldeisers is aangetast kan de

79. (1990), blz. 169-170. Zie voorts over het objectieve karakter van de aansprakelijkheid op grond van art. 138 Van den Hoek (1986), blz. 73. 
curator aanvulling ervan eisen.

Minder duidelijk is de problematiek van de werking van de decharge terzake van schade die aan het vennootschapsvermogen is toegebracht maar die niet ten nadele strekt van de gewone schuldeisers. Men denke bijvoorbeeld aan benadeling van het vermogen ten koste van aandeelhouders en andere gerechtigden tot het liquidatiesaldo, zoals houders van participatiebewijzen. Krachtens het achtste lid van art. 138, blijft de bevoegdheid van de curator om commissarissen wegens wanprestatie of onbehoorlijke taakvervulling ex art. 9 aan te spreken onverlet. In navolging van Raaijmakers $^{80}$ zou ik echter willen stellen dat een aan commissarissen verleende décharge aan aansprakelijkstelling door de curator in de weg staat. Slechts voor zover de vennootschap commissarissen niet heeft gedéchargeerd, of voor zover bij de verlening van de décharge enig voorbehoud is gemaakt, kan de curator deze rechten van de vennootschap uitoefenen. ${ }^{81}$

\section{b) Kennelijk onbehoorlijke taakvervulling}

Indien, zoals hiervoor betoogd is, art. 138 een lex specialis is ten opzichte van art. 9, dient te worden nagegaan welke de bijzondere elementen van de norm zijn.

Art. 9 stelt commissarissen aansprakelijk voor onrechtmatig handelen jegens de rechtspersoon in het kader van de taakvervulling of voor het handelen zonder de zorgvuldigheid die een goede commissaris betaamt. Dit onbehoorlijk handelen kan zich in beginsel voordoen bij elke schending van een norm die de commissaris bij zijn taakvervulling in acht dient te nemen. Een bijzondere vorm van onrechtmatigheid is niet vereist. Voor wat betreft de verwijtbaarheid terzake van dit onbehoorlijk handelen gelden mijns inziens eveneens de maatstaven van het gemene recht. ${ }^{82}$ Art. 138 is naar mijn mening een aansprakelijkheidsnorm van een andere orde dan art. 9 . In de literatuur wordt dit standpunt om verschillende redenen niet gedeeld. Gesteld wordt dat beide artikelen een verschillende categorie belanghebbenden beoogt te beschermen. $\mathrm{Bij}$ art. 9 zou het gaan om de rechtspersoon en bij art. 138 om zijn crediteuren. ${ }^{83}$ In het vorige nummer heb ik reeds trachten aan te geven waarom deze visie mij onjuist voorkomt. Volgens andere schrijvers bestaat tussen de twee aansprakelijkheden geen verschil omdat het element van "kennelijk" onbehoorlijke taakvervulling van art.

80. (1990), blz. 170-171.

81. Aan de décharge kan de werking ontvallen indien het déchargebesluit op grond van artt. 14 en/of 15 ongeldig blijkt te zijn.

82. Zie over het begrip onbehoorlijke taakvervulling \& $17,1, \mathrm{a}$.

83. Van Schilfgaarde (1986), blz. 19. 
138, welke aperte onrechtmatigheid en in de regel tevens grove schuld vereist, ook aanwezig dient te zijn bij de onbehoorlijke taakvervulling van art. 9. ${ }^{84}$ Het lijkt mij dat deze visie niet correct is. Onomstreden is in ieder geval dat volgens art. 138 de onrechtmatigheid van het handelen buiten kijf dient te staan. Dit wil zeggen dat iedere goede commissaris in de gegeven omstandigheden had behoren te begrijpen dat zijn handelen als onbehoorlijk moest worden gekwalificeerd. Dit wordt in art. 138 door het woord "kennelijk" duidelijk gemaakt, of, zoals Van den Hoek het uitdrukt, "geobjectiveerd". ${ }^{85}$ In zoverre zou men wellicht kunnen verdedigen dat deze norm, deze onrechtmatigheidsgraad, overeenkomt met die van art. 9. Maar uit de omstandigheid dat het onbehoorlijk handelen van art. 138 een belangrijke oorzaak van het faillissement moet zijn volgt mijns inziens, dat onder de werking van art. 138 slechts ernstige vormen van onbehoorlijke taakvervulling vallen. Bovengenoemde schrijvers stellen dat voor art. 9 eenzelfde maatstaf geldt, quod est demonstrandum. Bij de bespreking van art. 9 heb ik trachten aan te tonen dat er geen reden is om terzake van de onrechtmatigheid van dat handelen bijzondere maatstaven aan te leggen. Elk handelen in strijd met wet en statuten brengt in beginsel onbehoorlijke taakvervulling in de zin van art. 9 mede. Dit is naar mijn mening niet het geval bij art. 138. Hier zal niet elke vorm van onbehoorlijke taakvervulling als "kennelijk onbehoorlijk" worden aangemerkt. De onbehoorlijke taakvervulling die deze norm vereist is een zodanige die het faillissement van de vennootschap in belangrijke mate heeft veroorzaakt. Zulks zal zich slechts voordoen wanneer wettelijke of statutaire bepalingen met voeten worden getreden. Zo zal bijvoorbeeld een commissaris die zijn vergaderplicht niet nakomt in strijd handelen met art. 9, doch onder normale omstandigheden zal deze onbehoorlijke taakvervulling niet als kennelijk onbehoorlijk in de zin van art. 138 kunnen worden aangemerkt omdat zij niet dusdanig ernstig is dat zij tot het faillissement van de vennootschap leidt.

In het systeem van de wet leidt de verzwaarde aansprakelijkheid voor de gedragingen ex art. 138 tot een van art. 9 afwijkend regime voor wat betreft andere elementen van de onbehoorlijke taakvervulling, zoals de verwijtbaarheid, de causaliteit en de omvang van de vergoedingsplicht. ${ }^{86}$ De wet zwijgt weliswaar over de mate van schuld in art. 138, doch uit de ernst van de onrechtmatige gedraging lijkt te moeten volgen dat de onbehoorlijk handelende personen een ernstig verwijt zal kunnen worden gemaakt. Zulks is, naar hetgeen ik eerder betoogd heb, mijns inziens niet

84. Zo bijvoorbeeld Lowensteyn, TVVS 1983, blz. 176; Van den Hoek (1986), blz. 73; Maeijer (1991), blz. 10.

85. (1986), blz. 73.

86. Nader hierover De Groot (1986), blz. 1308 e.v. 
noodzakelijk voor de toepasselijkheid van art. 9. Verschil bestaat voorts waar het betreft het causale verband tussen het onbehoorlijk handelen en de schade, omdat art. 138 bepaalde vermoedens bevat die het bestaan van een causaal verband helpen vaststellen. Daarnaast geldt terzake van de te vergoeden schade bij toepasselijkheid van art. 138, anders dan in het geval van art. 9, niet de algemene norm van art. 6:98 BW. De vergoedingsplicht is beperkt tot het tekort van de boedel. Tenslotte zijn, in afwijking van het bepaalde in art. 6:109, bijzondere matigingsregels van toepassing. ${ }^{87}$

Op grond van het voorgaande zou ik willen concluderen dat art. 138 een verzwaarde aansprakelijkheidsnorm bevat ten opzichte van art. 9. Volgens art. 138 zijn bestuurders en commissarissen aansprakelijk voor ernstige vormen van onbehoorlijke taakvervulling die tot het faillissement van de vennootschap hebben geleid. Voor zover er sprake dient te zijn van onbehoorlijke taakvervulling, impliceert zulks dat bij toepassing van art. 138 ook steeds de norm van art. 9 geschonden is. ${ }^{88}$ Beide artikelen verhouden zich dan ook tot elkaar als species en genus.

\section{c) Collectieve verantwoordelijkheid en hoofdelijke aansprakelijkheid}

Hiervoor ${ }^{89}$ heb ik gesteld dat in het systeem van de wet de toezichthoudende taak toekomt aan de rvc als orgaan. De rechtshandelingen die nodig zijn voor de uitoefening van deze taak dienen, om te kunnen gelden als rechtshandelingen van de vennootschap, door de raad als orgaan te worden verricht. Dit brengt met zich mee dat in de regel ook het orgaan als geheel betrokken zal zijn bij de feitelijke verrichtingen die te takuitoefening vereist. In ieder geval draagt de rvc de verantwoordelijkheid voor deze rechtshandelingen en verrichtingen omdat de toezichthoudende taak aan hem is toevertrouwd. Het feit echter dat het orgaan kan zijn samengesteld uit meerdere natuurlijke personen is rechtens niet zonder betekenis. Een zeker onderscheid moet worden gemaakt tussen het orgaan en zijn leden. Mogelijk heeft het orgaan zijn taak voortreffelijk vervuld, terwijl écn of meer leden in hun persoonlijke taakvervulling in ernstige mate tekort

87. Zie hierover Maeijer (199l), blz. 7 e.v.

88. Anders Van Schilfgaarde (1986), blz. 20. Volgens hem houdt schending van art. 138 niet per se handelen in strijd met art. 9 in, en omgekeerd. Zulks omdat de door de twee normen beschermde personen verschillend zijn. Onrechtmatig handelen jegens de ene groep brengt niet noodzakelijkerwijs hetzelfde mee voor de andere groep. Ik heb reeds boven gesteld dat deze visie mij ongegrond lijkt omdat onbehoorlijke taakvervulling in beide gevallen onrechtmatig is jegens de rechtspersoon. Zie $\$ 17, \mathrm{II}, \mathrm{a}$.

89. $\$ 17, \mathrm{I}, \mathrm{a}$. 
geschoten zijn. De omgekeerde situatie kan zich eveneens voordoen.

Volgens art. 9 (jo. art. 149) is iedere commissaris gehouden tot een behoorlijke uitoefening van zijn taak. Schiet hij daarin tekort, dan kan hij aansprakelijk worden gesteld voor schade die de vennootschap leidt ten gevolge van zijn onbehoorlijke taakvervulling. Aldus rust op de commissaris analogisch dezelfde plicht als op iedere schuldenaar terzake van de nakoming van zijn verbintenis (art. 6:74,75). De commissaris draagt voor de vervulling van zijn taak een bepaalde verantwoordelijkheid en is in geval van tekortkoming aansprakelijk. Echter, omdat hij tevens deel uitmaakt van een orgaan dat door de wet als een eenheid is gedacht, draagt hij ook een zekere verantwoordelijkheid voor de taakuitoefening van het orgaan als geheel. Naast de persoonlijke verantwoordelijkheid voor wat betreft zijn eigen ambt draagt de commissaris derhalve een zgn. collectieve verantwoordelijkheid voor wat betreft de takkvervulling door het orgaan. Met deze collectieve verantwoordelijkheid hangt ook samen een zekere aansprakelijkheid. Voorzover de taakuitoefening van het orgaan feitelijk het resultaat is van de cumulatie van de individuele taakuitoefening van alle commissarissen, kan men ook stellen dat iedere commissaris een zekere verantwoordelijkheid draagt voor de taakuitoefening van zijn mede-commissarissen.

Omtrent de precieze inhoud van collectieve verantwoordelijkheid en hoofdelijke aansprakelijkheid, alsook over de verhouding tussen beide begrippen, bestaan in de literatuur uiteenlopende opvattingen. Mij dunkt dat de discussie over deze problematiek overheerst wordt door het aansprakelijkheidsmoment. Daarbij staat de vraag centraal wie voor welke handelingen aansprakelijk is. De belangstelling voor de aansprakelijkheidsvraag is waarschijnlijk hierdoor te verklaren dat de aansprakelijkheid in ieder geval in vermogensrechtelijk opzicht het belangrijkste rechtsgevolg is, zowel voor de vennootschap en haar crediteuren als voor de betrokken commissarissen (bestuurders) zelf. In zoverre de aansprakelijkheid echter het gevolg is van schending van het beginsel van collectieve verantwoordelijkheid, lijkt mij dat de aandacht zich primair moet richten op dit beginsel, omdat het bepalen van zijn draagwijdte conditio sine qua non is voor het intreden van aansprakelijkheid.

Allereerst moet worden nagegaan welke de verhouding is tussen de begrippen collectieve verantwoordelijkheid en hoofdelijke aansprakelijkheid. Hierover merkt Van Schilfgaarde $o p^{90}$ dat het beginsel van collectieve verantwoordelijkheid geen hoofdelijke aansprakelijkheid inhoudt, en ook niet met zich mee hoeft te brengen. De aansprakelijkheid van bestuurders en andere functionarissen is in zijn visie in beginsel een individuele.

90. (1986), blz. 14-15. 
Dit zou in overeenstemming zijn met art. 9, "dat uitgaat van individuele takvervulling en daarmee samenhangende individuele aansprakelijkheid (...) Voor collectieve of hoofdelijke aansprakelijkheid is in beginsel vereist dat aan ieder van de betrokkenen persoonlijk een verwijt kan worden gemaakt." Ik ben er niet zo zeker van dat dit zo is. Feit is in ieder geval dat de wet persoonlijke aansprakelijkheid ook koppelt aan collectieve verantwoordelijkheid. De vraag waar het mijns inziens omgaat is waarom de wet de individuele commissaris verantwoordelijk en aansprakelijk houdt voor verrichtingen die niet geheel de zijne zijn. Dit gebeurt naar mijn mening omdat collectieve verantwoordelijkheid evenzeer hoofdelijke aansprakelijkheid impliceert, als persoonlijke verantwoordelijkheid persoonlijke aansprakelijkheid. Dat aan iedere betrokkene een persoonlijk verwijt moet kurnen worden gemaakt opdat aansprakelijkheid intreedt wil mijns inziens zeggen dat een ieder het beginsel van collectieve verantwoordelijkheid moet hebben geschonden. Heeft iemand dat niet gedaan, dit wil zeggen: kan de tekortkoming aan een van de betrokkenen niet worden toegerekend, dan is hij niet aansprakelijk. Echter, het persoonlijk verwijt is in het geval van schending van de collectieve verantwoordelijkheid ratione materiae van een andere aard dan het verwijt dat aan de individuele commissaris wordt gemaakt terzake van tekortkomingen in zijn persoonlijke taakvervulling. In dit laatste geval handelt hij onrechtmatig jegens de rechtspersoon terzake van een verrichting die tot zijn persoonlijke taakvervulling behoorde ${ }^{91}$, terwijl het verwijt op grond van collectieve verantwoordelijkheid een aangelegenheid betreft die primair niet tot zijn competentie behoorde. Is dit dan niet een bevestiging van Van Schilfgaarde's visie dat de wet uitgaat van persoonlijke verantwoordelijkheid en aansprakelijkheid? Dit is in zekere zin het geval in zoverre de verplichtingen die op de commissaris rusten zijn individueel handelen betreffen. Maar omdat in het systeem van de wet de commissaris niet een geïsoleerde figuur is, doch een lid van een meerhoofdig orgaan dat idealiter als eenheid optreedt, is hij in beginsel ook persoonlijk verantwoordelijk voor de verrichtingen van het orgaan als geheel. De taakvervulling van de commissaris is in het wettelijm. ke systeem een deelname aan de taakvervulling van de raad. Zijn taakvervulling kan niet los worden gezien van die van de raad. In zoverre lijkt mij dat collectieve verantwoordelijkheid hoofdelijke aansprakelijkheid impliceert van al diegenen die deelnemen aan de collectieve taakvervulling.

Vervolgens rijst de vraag naar de toerekening van eigen handelingen van de

91. Of, in de woorden van de Hoge Raad met betrekking tot een bestuurder: terzake van "zijn aandeel in het bestuur", HR 4 december 1992, NJ 1993, 271 (Meijers/Mast). 
individuele commissaris aan de raad als orgaan, en andersom. Het komt mij voor dat het niet mogelijk is op deze vraag een absoluut antwoord te geven omdat de materie nauw verweven is met omstandigheden van feitelijke aard. De vraag kan daarom alleen van geval tot geval worden beantwoord. Anderzijds betekent zulks niet dat aan de wet geen aanknopingspunten kunnen worden ontleend die tot een antwoord zouden kunnen leiden.

Van belang in dit kader is vast te stellen of een taakverdeling binnen het orgaan mogelijk is. Is dat niet het geval, dan lost het probleem zich van zelf op omdat ieder orgaanlid verantwoordelijk is voor de gehele taak van het orgaan. Dit betekent, vertaald naar de zojuist gestelde vraag, dat alle verrichtingen van het orgaan aan de individuele leden kunnen worden toegerekend. Indien daarentegen een zekere werkverdeling mogelijk is, zullen de orgaanleden die niet belast zijn met de onbehoorlijke handelingen in beginsel daarvoor geen verantwoordelijkheid dragen, en daarom ook niet aansprakelijk zijn. Dit althans wanneer taakverdeling niet enkel verstaan wordt als een feitelijke verdeling van werkzaamheden maar als een juridische concretisering van de prestatieplicht van de orgaanleden. De praktische betekenis van dit alles schuilt hoofdzakelijk in de verdeling van de bewijslast, wanneer het op een procedure zou aankomen. ${ }^{92}$ Bevrijding van aansprakelijkheid zou in beginsel volgen voor het orgaanlid dat bewijst dat hij geen verantwoordelijkheid hoefde te dragen voor de onbehoorlijke handelingen.

Over de mogelijkheid om een werkverdeling binnen de rvc (of het bestuur) tot stand te brengen zegt de wet niets met zoveel woorden. Waarschijnlijk kan echter worden aangenomen dat een dergelijke werkverdeling een in de praktijk aanvaard gebruik is. Zowel in grote als in kleine vennootschappen is het een ervaringsfeit dat bij een meerhoofdig orgaan - in het bijzonder bij een bestuursorgaan - een zekere taakverdeling plaats vindt. Primair is de taakverdeling een feitelijke aangelegenheid. Mogelijk is zij ingegeven door doelmatigheidsoverwegingen. Ik ga er vanuit dat wanneer het bestuur of de raad van commissarissen zijn werkzaamheden onder de leden verdeelt deze organen een optimale vervulling van de taak door de individuele leden trachten te bereiken. Niet gestreefd wordt, zo neem ik aan, naar een juridische splitsing van de leidinggevende of de toezichthoudende taak, aldus dat meerdere organen worden gecreëerd die ieder een eigen verantwoordelijkheid dragen voor de toevertrouwde deeltaak. Dortmond ${ }^{93}$ meent dat wanneer art. 9 over "werkkring" spreekt, het "zo moet worden verstaan, dat alleen bij die rechtspersonen, waarbij

92. In deze zin Van Schilfgaarde, (1986), blz. 18.

93. (1990), blz. 17. 
men de bestuurstaak als geheel kan splitsen over twee of meer bestuurders of bestuurlijke organen, die dan ieder een afzonderlijk opgedragen bestuurstaak hebben, het mogelijk is dat een aangelegenheid niet tot de werkkring van een bestuurder behoort." Hij stelt voorts: "Alleen bij enkele rechtspersonen kan nog een onderscheid worden gemaakt tussen twee besturen met ieder een eigen werkkring; bij een $\mathrm{nv}$ of bv is dat niet toegestaan. Ik meen dan ook dat de werkkring in art. 8 geen betekenis meer heeft voor de nv of bv en dat voor die rechtspersonen in art. 8 de bijzin die begint met 'indien', geen betekenis meer heeft, zodat de vraag of iets tot de werkkring van meer bestuurders behoort, en daarmee de werkkring, geen betekenis meer heeft." 94 Tegen deze visie lijken mij tweeërlei bezwaren te bestaan. Ik denk in de eerste plaats dat Dortmond de onsplitsbaarheid van de bestuurstaak bij NV en BV te absoluut stelt. Ik zie niet in waarom de raad van bestuur zijn bestuurstaak niet aldus zou kunnen inrichten dat er meerdere organen zouden zijn die ieder op een bepaalde manier zou bijdragen aan de vervulling van de collectieve bestuurstaak. In de raad van commissarissen kan bijvoorbeeld een gedelegeerde commissaris worden benoemd, wiens eigen taak geen afbreuk doet aan de collectieve verantwoordelijkheid van de andere commissarissen. Per modum analogiam kan zulks evenzeer voor het bestuur gelden ${ }^{95}$ En in de tweede plaats, ook wanneer men zou aannemen dat een taakverdeling zoals door mij verdedigd bij nv en bv niet mogelijk is, leidt de visie van Dortmond er toe dat het beginsel van collectieve verantwoordelijkheid elke betekenis verliest juist bij die rechtspersonen waarbij de door art. 9 -en als uitvloeisel hiervan de door art. 138- beschermde belangen toepasselijkheid van dit beginsel het meest rechtvaardigen. Het lijkt mij dat indien taakverdeling tot gevolg heeft dat meerdere organen ontstaan, eerder aannemelijk is dat ieder orgaan zijn eigen verantwoordelijkheid draagt. De noodzaak van het beginsel van collectieve verantwoordelijkheid doet zich in deze gevallen minder sterk gevoelen. Het aan art. 9 ten grondslag liggende beginsel van collectieve verantwoordelijkheid, maakt orgaanleden echter niet verantwoordelijk voor de taakvervulling van een ander orgaan, maar van het eigen orgaan.

lk zou menen dat de juridische betekenis van de taakverdeling wellicht

94. (1990), blz. 22.

95. Vgl. ook Maeijer in zijn noot onder HR 4 december 1992, NJ 1993, 271 (Meijers/Mast). I.c., merkt Maejer op, werd door eiser in cassatie het beginsel van collectieve verantwoordelijkheid bij collegiaal bestuur te zeer benadrukt. "Maar dit neemt niet weg dat ook een individuele bestuurder, die met bepaalde bestuurswerkzaamheden speciaal kan worden belast zonder dat beslissingen over bepaalde onderwerpen aan het bestuur als zodanig kunnen worden onttrokken (zie par. 8 departementale richtlijnen 1986), verantwoordelijk is. Dit komt ook tot uitdrukking in de eerste zin van art. 2:9 BW" (curs. ook in het origineel). 
aldus zou kunnen worden verklaard dat de wet het ervaringsfeit van werkverdeling aanvaardt en daardoor sanctioneert dat in ieder geval niet elk (onbehoorlijk) handelen terzake van de taakvervulling van het orgaan aan ieder lid wordt toegerekend. ${ }^{96}$

Vervolgens rijst de vraag naar de grenzen van deze taakverdeling. Wil het beginsel van collectieve verantwoordelijkheid enige betekenis hebben, dan moet worden aangenomen dat de individuele orgaanleden zich niet geheel kunnen onttrekken aan de totale taak van het orgaan. Hoewel hun verantwoordelijkheid primair ligt bij hun eigen werkkring dienen zij in ieder geval bekend te zijn met de hoofdlijnen van het beleid van de andere orgaanleden. Welke de exacte vertaling van dit alles in de praktijk is hangt af van tal van factoren, zoals de omvang van de onderneming, het aantal orgaanleden, de aard van de onbehoorlijke gedraging. Geheel juist lijkt mij in elk geval de opmerking van Van Schilfgaarde ${ }^{97}$ dat ieder orgaanlid gehouden is om binnen het kader van zijn bevoegdheden in te grijpen wanneer hij onbehoorlijke taakvervulling bij anderen zou constateren. ${ }^{98}$ Het komt mij voor dat dit ook de strekking art. 9 is waar geëist wordt dat het orgaanlid -wil hij gedisculpeerd zijn- niet nalatig is geweest in het treffen van maatregelen om de gevolgen van de tekortkoming af te wenden. Voorts werkt de taakverdeling niet ipso facto als een aansprakelijkheidsbevrijdende omstandigheid. Het beginsel van collectieve verantwoordelijkheid brengt naar mijn mening mee, dat het lid dat zich op de taakverdeling beroept niet kan volstaan met te bewijzen dat de tekortkoming buiten zijn eigen werkkring heeft plaatsgevonden. Hoewel dit een belangrijke omstandigheid is, dient hij nog andere omstandigheden aan te voeren op grond waarvan hem geen verwijt kan worden gemaakt van de concrete tekortkoming. ${ }^{99}$ Hoe ver de betrokken persoon dient te gaan is een vraag die van

96. Kennelijk in gelijke zin Van Schilfgaarde in zijn repliek aãn Dortmond, Plercing van Schilfgaarde, 1990, blz. 72 .

97. (1986), blz. 18.

98. Vgl. in dit verband in het Duitse recht Mertens, Kölner Kommentar, $\& 107$, Rz 127: "Die Übertragung einer Aufgabe auf einen Ausschuß, aber auch ein einzelnes Aufsichtsratsmitglied (...) verändert die Haftungssituation der anderen Aufsichtsratsmitglieder; denn sie selbst sind in diesem Fall von der Erfülung jener Aufgabe entlastet. Jedoch ist jedes Mitglied auf Grund der ihm persönlich obliegenden Pflicht zur Kontrolle des Vorstandes nicht nur dafür zu sorgen verpflichtet, daß die Aufgabenverteilung im AufsR zweckentsprechend organisiert ist, sondern vor allem auch dafür, daß sie ihm selbst jederzeit die Möglichkeit bietet, an der Überwachung des Vorst. in ausreichender Weise teilzunehmen. Das bedeutet: jedes AufsRMitglied ist dafür verantwortlich, daß der AufsR insgesamt seinem Aufgabenbereich voll gerecht wird." Zo ook Geßler, \$107, Rz 84.

99. Anders Van Schilfgaarde (1986), blz. 18. In zijn visie komt het lid aan disculpatie niet toe wanneer hij bewijst dat de tekortkoming buiten zijn werkkring viel. 
geval tot geval moet worden beantwoord.

De taakverdeling, zo kan het voorgaande worden samengevat, is rechtens relevant als een belangrijke omstandigheid die orgaanleden van verantwoordelijkheid voor de betrokken tekortkoming ontslaat indien de tekortkoming buiten de eigen werkkring heeft plaatsgevonden. Doordat zij geen verantwoordelijkheid dragen, zijn zij ook niet aansprakelijk. Doch dit ontslag van aansprakelijkheid volgt niet automatisch uit de werkverdeling. Naast de taakverdeling dienen andere omstandigheden te worden aangevoerd op grond waarvan aan betrokkene geen verwijt kan worden gemaakt. In zoverre zij niet automatisch als een 'schulduitsluitingsgrond' werkt is de betekenis van de taakverdeling beperkt. ${ }^{100}$

Voorgaande overwegingen hadden betrekking op art. 9. Zij zijn, naar het mij voorkomt, in beginsel ook van toepassing op de gevallen voorzien in art. 138. Zoals gezegd, bevat deze norm een uitwerking voor faillissementssituaties van de algemene aansprakelijkheidsregeling van art. 9. In het geval van art. 138 gaat het om een tekortkoming die in belangrijke mate het faillissement van de vennootschap heeft veroorzaakt. In deze omstandigheid schuilt het voornaamste verschil met art. 9. De aard van de tekortkoming maakt tevens dat het beginsel van collectieve verantwoordelijkheid aan betekenis wint. Immers, in tegenstelling tot art. 9 betreft art. 138 een ernstige tekortkoming van de rvc welke tot het faillissement van de vennootschap leidt. In dit geval lijkt mij dat het beginsel van collectieve verantwoordelijkheid met zich mee brengt dat de tekortkoming aan alle orgaanleden kan worden toegerekend. Volgens Van Schilfgaarde ${ }^{101}$ kan uit dat beginsel echter "niet voortvloeien dat handelingen van individuele bestuurders onder alle omstandigheden als handelingen van 'het bestuur' hebben te gelden. Met name in gevallen waarin een bestuurder geheel op eigen houtje of tegen de uitdrukkelijke wensen of instructies van het bestuur gehandeld heeft, stuit een dergelijke gedachte op onoverkomelijke bezwaren" (mijn curs.). Deze bezwaren komen mij eveneens gegrond voor. Doch de taakverdeling heeft met de door schrijver genoemde omstandigheden mijns inziens weinig te maken. Onder die omstandigheden zullen de overige orgaanleden zich kunnen disculperen omdat de zondaar zich aan de controle van het orgaan onttrok, en niet omdat de gewraakte handeling niet tot hun werkkring behoorde. ${ }^{102}$ Het feit dat handelingen die tot het faillissement van de vennootschap hebben geleid in beginsel aan het gehele orgaan kunnen worden toegerekend betekent niet dat zulks onder alle

100. Zo ook Dortmond (1990), blz. 13 e.v., die echter, zoals hiervoor bleek, deze omstandigheid naar mijn mening te beperkt opvat.

101. (1986), blz. 52.

102. Zo ook Dortmond (1990), blz. 15-16, met een beroep op de wetsgeschiedenis. 
omstandigheden mogelijk is. De taakverdeling is hier minder relevant dan bij de gewone bedrijfsuitoefening waarop art. 9 betrekking heeft omdat het hier gaat om een zeer ernstige tekortkoming, waartegen in beginsel ieder orgaanlid behoort te waken. Voorts is in dit geval mijns inziens niet van belang of de tekortkoming een gevolg is van een gedraging van het orgaan als geheel of van een individueel lid. ${ }^{103}$ Dit volgt mijns inziens zowel uit de strekking van art. 138 als uit het beginsel van collectieve verantwoordelijkheid. De strekking van genoemd voorschrift is crediteuren van de vennootschap te beschermen tegen aantasting van het vennootschapsvermogen door toedoen van bestuurders en commissarissen. In deze opzet dienen de aansprakelijke personen en niet de crediteuren het risico te dragen voor de handelingen van de individuele leden van bestuur en rvc. Ook uit het beginsel van collectieve verantwoordelijkheid volgt dat tekortkomingen van een individueel lid, die tot faillissement leiden, in principe aan alle leden van het orgaan kunnen worden toegerekend. Onder omstandigheden is disculpatie van de onschuldige leden mogelijk op grond van lid 3 .

\section{\$18. Tegenstrijdig belang van een commissaris met de vennootschap}

Alle betrokkenen bij de "organisatie" van de rechtspersoon moeten hun wettelijke en statutaire rechten jegens de rechtspersoon en, voor zover deze rechten bestaan, jegens andere "betrokkenen" naar redelijkheid uitoefenen (art. 8). Deze verplichting wordt in art. 9 jo. 149 voor commissarissen nader uitgewerkt. Commissarissen zijn jegens de rechtspersoon verplicht tot een behoorlijke uitoefening van hun taak. Dit houdt in dat zij in de uitoefening van hun taak, zo veel als van een goede commissaris in de gegeven omstandigheden gevraagd kan worden, het belang van de vennootschap dienen te behartigen (art. 140). Voor zover commissarissen zich in een situatie kunnen bevinden waarbij een persoonlijk belang betrokken is dat tegengesteld is aan dat van de vennootschap doet zich de vraag voor hoe zij

103. Zo ook Maeijer (1991), blz 9 en Van Schilfgaarde (1986), blz. 53, voor wie ook handelingen van individuele leden tot toepassing van art. 138 kunnen leiden. Wegens de interne taakverdeling kunnen, volgens Van Schilfgaarde, andere leden zich echter op grond van lid 3 bevrijden. Deze laatste opmerking lijkt mij i.c., om de in de tekst genoemde redenen, in strijd met het beginsel van collectieve verantwoordelijkheid. Anders Handboek, nr, 399.1. Alleen handelingen van het orgaan als college kunnen volgens Van der Grinten tot aansprakelijkheid leiden. Hij beroept zich daarbij op de tekst van de wet. 


\section{TEGENSTRIJDIG BELANG}

daarbij dienen te handelen. ${ }^{104}$

De problematiek van het tegenstrijdig belang is niet specifiek van commissarissen. Men zou kunnen stellen dat het in ons recht als een beginsel heeft te gelden dat de persoon die krachtens wet of rechtshandeling andermans belangen dient te behartigen zijn persoonlijke belangen gescheiden moet houden van die van de persoon voor wie hij optreedt. Dit blijkt vooral op het voornaamste gebied van belangenbehartiging, te weten de vertegenwoordiging. ${ }^{105}$ Art. 3:68 BW beoogt de vertegenwoordiger te weerhouden van het verrichten van rechtshandelingen als wederpartij van zijn vertegenwoordigde indien belangen van beide partijen zouden kunnen conflicteren. ${ }^{106}$ Dit beginsel is echter niet absoluut. Onder omstandigheden staat het de rechtsgenoten vrij hiervan af te wijken. Zo laten de artt. 12, 146 en 3:68 toe dat de persoon bij wie de tegenstrijdige belangen samenvallen aan beide zijden van de rechtsverhouding optreedt. Voor wat betreft het vennootschapsrecht kent de wet twee bepalingen die specifiek de situatie van tegenstrijdig belang regelen. De eerste is art. 146. Daarnaast opent art. 12 de mogelijkheid om in de statuten het stemrecht aan bepaalde personen te ontnemen indien, kort gezegd, zich een geval van tegenstrijdig belang voordoet.

Van het handelen met tegenstrijdig belang moet worden onderscheiden het handelen in dienst van een bepaald belang. Het vennootschappelijk belang, waartoe de uitoefening van de commissariële bevoegdheden zich richt, is niet een abstracte grootheid die vreemd is aan de belangen van concrete mensen of instanties die bij de vennootschap zijn betrokken. Wanneer de wet stelt dat commissarissen het vennootschappelijk belang moeten dienen, brengt zij naar mijn mening daarmee tot uitdrukking dat commissarissen moeten toezien op de verwezenlijking van het vennootschappelijke

104. Op deze plaats kan voorbij worden gegaan aan de verschillende vormen van tegenstrijdig belang waarin commissarissen kunnen verkeren. Zie hierover Dorres teijn (1989), blz. 10 e.v.

105. Strikt gesproken behoeft de vertegenwoordiger de belangen van zijn vertegenwoordigde niet te behartigen. Vertegenwoordiging is een abstracte rechtsfiguur. Haar wezen is niet de behartiging van andermans belangen, doch de verrichting van rechtshandelingen voor een ander. Niettemin behoort "belangenbehartiging tot het 'normale type' van de vertegenwoordiging", aldus Asser-Van der Grinten $I, \mathrm{nr}$. 8. Hoewel de vertegenwoordigingsmacht in beginsel los staat van mogelijke onderliggende verhoudingen tussen vertegenwoordiger en vertegenwoordigde, kan zij niet geheel worden geabstraheerd van deze verhoudingen. Vgl. Asser-Van der Grinten I, nr. 16, Flume (1979), $\$ 45$ II 2-3 en $\S 48$ en Diez Picazo (1979), blz. 199 e.v.

106. Zie voorts artt. 1:250 en 7:409 BW. 
doel. ${ }^{107}$ Dit doel is idealiter het doel dat de gezamenlijke oprichters/aandeelhouders zich hebben gesteld bij de oprichting en instandhouding van de vennootschap. Niet geheel correct lijkt mij daarom het in de literatuur algemeen gangbaar standpunt dat de commissaris onafhankelijk is van de concrete belangen die bij de vennootschap zijn betrokken. Indien men met deze "onafhankelijkheid" bedoelt dat de commissaris niet gebonden is aan de aanwijzingen van een ander orgaan is dit juist omdat uit de wet blijkt dat commissarissen een eigen verantwoordelijkheid dragen voor hun taakvervulling. Deze verantwoordelijkheid zou niet kunnen bestaan wanneer commissarissen niet gerechtigd zouden zijn tot een onafhankelijke taakuitoefening. De raad van commissarissen is orgaan van de rechtspersoon en niet een groep van lasthebbers. Doorgaans wordt de term "onafhankelijkheid" ook in feitelijke zin verstaan. Daarmee wordt bedoeld dat belangenbehartiging onverenigbaar is met de commissariële taak. Voor zover de rechtspersoon per definitie dienstbaar is aan concrete belangen, lijkt mij dat belangenbehartiging ook inherent is aan de commissariële taak. Dat de commissaris deze belangen niet onbeperkt ten koste van andere bij de vennootschap betrokken belangen mag dienen is een andere kwestie. ${ }^{108}$

Bij de behartiging van het vennootschappelijk belang zal de commissaris zich veelal laten leiden door de belangen van de persoon of instantie die zijn benoeming heeft bewerkstelligd. Strikt genomen is de benoeming afzonderlijke gevallen daargelaten (bijvoorbeeld art. 356b)- steeds een vennootschappelijke handeling. ${ }^{109}$ De vennootschap benoemt de conmissarissen. In zoverre deze bevoegdheden vennootschappelijke bevoegdheden zijn, is de commissaris gebonden aan het vennootschappelijk belang. Echter, reeds het feit dat onze wet de benoemingsbevoegdheid aan verschillende organen toekent laat zien dat, hoewel de benoeming rechtens geldt als handeling van de vennootschap, de feitelijke belangen die aan de benoeming ten grondslag liggen niet steeds dezelfde behoeven te zijn. Het paradigma is het benoemingsrecht van de overheid bij structuurvennootschappen (art. 158 lid 12).

Heeft men het over tegenstrijdig belang van commissarissen, dan gaat het naar mijn mening in wezen om een probleem van rechtsuitoefening. Gesteld als rechtsvraag luidt deze problematiek: hoe dienen de commissa-

107. Zie hiervoor $\$ 1, \mathrm{I}$.

108. Zie hierover $\$ 4$,III. Dat ook de Stat dit zo verstaat, zelfs in het geval van een structurvennootschap, blijkt bijvoorbeeld uit de agreements die bij de overname van Fokker door Dasa zijn gemaakt. Zie hierover Timmerman, TVVS 1992, blz. 260.

109. Zie $\$ 13,1$. 


\section{TEGENSTRIJDIG BELANG}

riële bevoegdheden te worden uitgeoefend? $?^{110} 111$ De problematiek is

110. Hierover moge ik twee opmerkingen maken. Op deze plaats wil ik niet in detail ingaan op de beantwoording van deze vraag in concrete situaties. Volstaan wordt met het aangeven van enkele criteria die het handelen met tegenstrijdig belang helpen op te lossen. Ten tweede, geldt hetgeen hierna volgt, gezien de analogie in rechtspositie, mutatis mutandis eveneens voor bestuurders.

111. Een korte rechtsvergelijkende opmerking over het Duits recht lijkt mij hier gewenst. (Uitvoerig hierover Dorresteijn (1989), passim.) Ulmer (NJW 1980, blz. 1604) onderscheidt bij tegenstrijdig belang drie situaties. In de eerste plaats die waarin het handelen als orgaan centraal staat. Het betreft hier handelingen in het kader van de toezichthoudende taak, waarbij commissarissen wettelijke of statutaire bevoegdheden uitoefenen. Men denke aan de bevoegdheid tot goedkeuring van bestuursbesluiten. Richtsnoer bij deze handelingen is het belang van de vennootschap. Commissarissen dienen eventuele eigen belangen bij de transactie aan dat der vennootschap te onderwerpen. In de tweede plaats stelt hij daartegenover situaties, waarin het handelen van de commissaris op geen enkele manier in verband staat met de juridische of zakelijke sfeer van de vennootschap. Het betreft hier het leeuwedeel van de privé-rechtshandelingen van de commissaris. In deze gevallen is de commissaris vrij zijn eigen belang na te streven. Moeilijkheden kunnen zich voordoen in de gevallen die door Ulmer in de derde plaats worden genoemd. Het gaat dan om handelingen door de commissaris anders dan in deze hoedanigheid verricht, waarbij de zakelijke of juridische sfeer van de vennootschap wel betrokken kan zijn. Men denke aan transacties die zijn aangegaan tussen de vennootschap en de commissaris in privé of in een andere kwaliteit. Deze laatste constellatie kan zich bijvoorbeeld voordoen bij transacties tussen twee vennootschappen waarin de persoon in kwestie commissaris is. Men denke aan het uitbrengen van een vijandig bod. (Vgl. voor een voorbeeld uit de Amerikaanse praktijk, met gevolgen voor de betrokken director -handelend als executive director van de biedende vennootschap en als outside director van de over te nemen vennootschap-, Lutter (1981), blz. 232). Voor dit soort gevallen geldt volgens Ulmer (t.a.p., blz. 1607) hetzelfue criterium als voor de tweede groep gevallen: de commissaris is niet aan het vennootschappelijk belang gebonden. Anders zou moeten worden beoordeeld "wenn das Aufsichtsratsmitglied die Grenzen von Haupt- und Nebentätigkeit verwischt und sich im Rahmen der Haupttätigkeit Einflußmöglichkeiten aus den Nebenamt zunutze macht."

Een soortgelijk criterium wordt door Werner (ZHR 1981, blz. 258) gehanteerd. Hij onderscheidt tussen schadelijke Auswirkungen en Einwirkungen. In het eerste geval ontstaat voor de vennootschap schade op grond van een handeling die de commissaris verplicht of gerechtigd is te verrichten anders dan in de hoedanigheid van commissarissen. "Für derartige Auswirkungen gilt grundsätzlich das Prinzip, daß bei Pflichterfillung innerhalb eines Bereichs die Interessenlage des jeweils anderen Bereichs unberücksichtigt zu bleiben hat." Men denke aan het geval dat de commissaris in prive een concurrerende vennootschap financieel steunt. In het tweede geval daarentegen gebruikt de commissaris zijn positie binnen de vennootschap om een voordeel te behalen ten koste van de vennootschap. Dit is het spiegelbeeld van de vorige situatie. Men denke aan de commissaris die het

(Wordt vervolgd...) 
gelijk aan die van het tegenstrijdig belang van bestuurders, waarvoor art. 146 een voorziening bevat. Bij de bespreking van deze voorziening heb ik verdedigd dat de situatie van tegenstrijdig belang zich voordoet wanneer de bestuurder in de positie verkeert dat hij zijn taak onbehoorlijk vervult omdat hij zich daarbij laat leiden door een eigen belang. ${ }^{12} \mathrm{Om}$ dit risico te voorkomen geeft de wet de voorziening van art. 146. Er is mijns inziens alle reden om deze bepaling analoog toe te passen op commissarissen. ${ }^{113}$ Dit volgt niet alleen uit art. 8 -waarin het bovenvermeld beginsel van scheiding van belangen besloten ligt- maar met name uit het feit dat de strekking van de bepaling in gelijke mate geldt voor commissarissen. De voorziening van art. 146 is een gevolg van de plicht van bestuurders om in de uitoefening van hun taak het vennootschappelijk belang te dienen. Deze plichtsgebondenheid is, anders dan bij de commissarissen (art. 140), niet expliciet in de wet neergelegd. In zoverre voor commissarissen dezelfde plichtgebondenheid bestaat als voor bestuurders, dient te worden aangenomen dat ook voor commissarissen dezelfde beperking van art. 146 geldt, hoewel dit niet expliciet in de wet is neergelegd.

Een andere voorziening ter voorkoming van tegenstrijdig belang vormt art. 12. ${ }^{114}$ Hoewel dit artikel primair bedoeld is om uitsluiting van het stemrecht van aandeelhouders mogelijk te maken, moet in navolging van Mohr worden aangenomen dat de strekking van het artikel -mede gezien tegen de achtergrond van de wettelijke regeling (art. 146 jo. 8)- meebrengt dat de daarin voorziene uitsluiting van het stemrecht ook kan gelden voor leden van andere organen. ${ }^{115}$ Naar mijn mening behelst dit artikel een nadere uitwerking van het beginsel van art. 8 , en beoogt het te bereiken dat de besluiten van de rechtspersoon -dus elk besluit ongeacht het besluitnemende

\section{1.(...vervolg)}

vermogen van de vennootschap tot zekerheid van privé-schulden aanwendt. Dit moet volgens Werner als ongeoorloofd worden beschouwd. Zie voorts over het onderwerp Fleck (1991).

112. $\$ 3$, III.

113. Volgens Dorresteijn (1989), blz. 52, echter is het toepassingsgebied van het artikel tot bestuurders beperkt.

114. Dit bepaald onduidelijk artikel (milder hierover Timmerman (1991), blz. 55: "moeilijk leesbaar") luidt: "Het stemrecht over besluiten waarbij de rechtspersoon aan bepaalde personen, anders dan in hun hoedanigheid van lid, aandeelhouder of lid van een orgaan, rechten toekent of verplichtingen kwijtscheldt, kan door de statuten aan die personen en aan hun echtgenoot en bloedverwanten in de rechte lijn worden ontzegd."

115. (1993), blz. 78-79. 
orgaan- beantwoorden aan de eisen van redelijkheid en billijkheid. ${ }^{116}$ Statutair kan dan ook worden bepaald dat commissarissen het stemrecht niet zullen kunnen uitoefenen indien het besluit in kwestie een transactie betreft waarin een situatie van tegenstrijdig belang zich voordoet.

Relevant bij een situatie van tegenstrijdig belang van commissarissen is de zorgvuldigheid in de besluitvorming van de rvc. Immers, hiervoor is gesteld dat de problematiek van tegenstrijdig belang een aangelegenheid betreft van correcte uitoefening van de commissariële bevoegdheden, en deze vindt plaats door middel van besluitvorming. ${ }^{117}$

Het is omstreden in hoeverre de aanwezigheid van een tegenstrijdig belang rechtvaardigt dat an de betrokken commissaris vergader- en stemrechten worden ontzegd. Met een beroep op de Wijsmuller-regel, volgens welke "het besluit tot stand komt als vrucht van onderling overleg van alle leden van dat orgaan ${ }^{118}$, neigt Eisma ${ }^{119}$ ertoe aan te nemen, dat de commissaris niet uitgesloten kan worden van deelname aan de vergadering en/of stemming over het bewuste besluit. Dat deelname aan de vergadering in geval van tegenstrijdig belang in strijd zou zijn met redelijkheid en

116. Aan de andere kant moet het belang van deze bepaling niet worden overschat. De tegenstrijdigheid van belangen tussen vennootschap en aandeelhouder is wegens de aard van de vennootschap relatief. Ware dit anders dan zou het artikel niet een dispositieve norm bevatten maar een imperatieve bepaling naar het voorbeeld van art. 3:43 BW zijn. Anders dan bij openbare ambten het geval is, brengt redelijkheid en billijkheid niet met zich mee dat de aandeelhouder in de uitoefening van zijn stemrecht vreemde belangen behartigt. Ook het door Mohr (1993), blz. 83, in dit kader aangehaalde arrest van de Hoge Raad inzake Van Waning/Van der Vliet (HR 3 april 1992, NJ 1992, 411) leidt niet tot andere conclusies. Deze uitspraak is -zoals elke uitspraak over onrechtmatige daad- gedaan met inachtneming van "de zeer specifieke achtergronden van de casus", zoals Mohr, blz. 84 terecht stelt. De Hoge Raad bepaalt daarin dat een aandeelhouder/bestuurder in privé gehouden kan zijn te bewijzen dat de vennootschap waarover hij volledige zeggenschap heeft niet in staat is aan haar schulden jegens een bepaalde schuldeiser te voldoen. Deze plicht betreft niet een vennootschapsrechtelijke verhouding. Zij vloeit niet voort uit art. 8 maar uit art. 6:162. Met de problematiek van art. 12 heeft deze omkering van bewijslast mijns inziens niets van doen.

117. Voorkomen is veelal beter dan genezen. Zowel op de vennootschap als op de (kandidaat)commissaris kan de plicht rusten om maatregelen te treffen die er op gericht zijn tegenstrijdige belangen te vermijden. Het jegens alle betrokkenen betrachten van maximale openheid over de transactie die aanleiding geeft tot het tegenstrijdig belang is steeds noodzakelijk. Enkele criteria zijn te vinden in OK 26 mei 1983, NJ 1984, 481 (Linders/Hofstee). Zie voorts de noot van Maeijer onder deze uitspraak en Dorresteijn (1989), blz. 62 e.v.

118. HR 15 juli 1968, NJ 1969, 101.

119. (1993), blz. 38. 
billijkheid laat zich, volgens deze schrijver, "in theorie denken, maar in concreto is het toch moeilijk voorstelbaar." Naar mijn mening is het echter vanzelfsprekend dat de commissaris uitgesloten kan worden van deelname en stemming omdat, zoals Eisma zelf aangeeft, de regels omtrent totstandkoming van besluiten niet gelden voor zover een hoger rechtsbeginsel, i.c. de behoorlijke taakuitoefening en besluitvorming in het belang van de vennootschap, zich daartegen verzet. Eisma meent echter dat "het uitsluiten van een niet vrijwillig terugtredende commissaris van het verdere beraad en/of besluitvorming binnen de raad van commissarissen in wezen neerkomt op een tijdelijke schorsing." Daartoe is de rvc in de regel slechts bij structuurvennootschappen bevoegd. Dit verschil in rechtsregime tussen gewone en structuurvenootschap is volgens schrijver met het wettelijk systeem in strijd. Zonder dit laatste te willen ontkennen, meen ik toch dat de gestelde analogie met de schorsing onjuist is, en het aangevoerde argument daarom ongegrond. Uitsluiting van vergader- en stemrecht heeft met schorsing inderdaad gemeen dat bepaalde bevoegdheden door betrokkene niet kunnen worden uitgeoefend. Schorsing is echter een maatregel die de wet het bevoegde orgaan laat treffen, indien zulks naar het oordeel van dit orgaan nodig is. Uitsluiting van het vergader- en stemrecht in een situatie van tegenstrijdig belang is een aan het ambt inherente beperking, die tot doel heeft onbehoorlijke taakvervulling door de commissaris tegen te gaan. ${ }^{120}$ Tegen deze uitsluiting verzet zich niet het beginsel van art. 12, namelijk dat een orgaanlid zijn bevoegdheden ook in een situatie van tegenstrijdig belang kan uitoefenen zolang statutair niet anders is bepaald. Indien in de statuten de voorziening van art. 12 niet is getroffen, betekent zulks niet dat commissarissen steeds bevoegd zijn tot uitoefening van de aan hun ambt verbonden bevoegdheden. ${ }^{121}$ Of zulks in een concreet geval mogelijk is staat ter beoordeling van de rvc. Omdat uitsluitingen van vergader- en stemrecht geen maatregel is, doch een aan het ambt verbonden beperking, doen zich de door Eisma gesignaleerde bevoegdheidsmoeilijkheden mijns inziens niet voor.

Het betoog van Eisma geeft overigens wel aan, waarin het voornaamste probleem schuilt bij een situatie van tegenstrijdig belang. De betrokken commissaris kan namelijk het uitoefenen van zijn bevoegdheid worden belet. Indien het probleem een blijvend karakter heeft, kan zulks de onmogelijkheid met zich brengen om de commissariële taak uit te oefenen. In zo'n geval is de enige uitweg dat de commissaris én van de conflicterende

120. Zo ook Van der Grinten, De NV 70 (1993), blz. 249

121. Terecht stelt Timmerman (1991), blz. 56, dan ook dat het feit dat geen gebruik is gemaakt van de voorziening van art. 12 op zich geen beletsel vormt om een besluit, dat tot stand is gekomen in een situatie van tegenstrijdig belang, te vernietigen wegens strijd met de goede trouw (art. 15 lid 1 sub b). 
functies neerlegt. Dat de blijvende aanwezigheid van een tegenstrijdig belang de (kandidaat)commissaris ongeschikt maakt voor benoeming of handhaving in de functie, lijkt mij duidelijk. ${ }^{122}$ In hoeverre een dergelijke situatie zich voordoet, kan alleen van geval tot geval worden beoordeeld. Het enkel potentieel bestaan van een tegenstrijdig belang acht ik in ieder geval onvoldoende.

Tot besluit, welke zijn de gevolgen van het onrechtmatig handelen in een situatie van tegenstrijdig belang.

Onderscheiden moet worden tussen de gevolgen voor de commissaris en de vennootschap enerzijds en voor de wederpartij bij de transactie anderzijds.

In de interne sfeer kan het besluit worden vernietigd op grond van art. 15 lid 1 sub a, voorzover aan de totstandkoming van het besluit gebreken kleven. Het besluit kan ook vernietigbaar zijn op grond van hetzelfde artikellid sub b. Daarnaast kan de commissaris worden aangesproken wegens onbehoorlijke taakvervulling (art. 9) en, indien door de onbehoorlijke taakvervulling de vennootschap schade heeft geleden, tot vergoeding van de veroorzaakte schade.

In de externe sfeer kunnen de gevolgen van het onrechtmatig handelen van de commissaris beperkter zijn. Er van uitgaande dat de externe rechtshandeling niet nietig is, kan zij in beginsel niet worden vernietigd wanneer de vennootschap daarbij rechtsgeldig is vertegenwoordigd. De vennootschap zou slechts dan niet gebonden zijn indien de wederpartij niet te goeder trouw was, bijvoorbeeld omdat zij wist dat de transactie gepaard ging met het onrechtmatig handelen van de commissaris. Naar mijn mening is het daarbij niet noodzakelijk dat de rechtshandeling een vermogensrechtelijk nadeel voor de vennootschap meebrengt. Immers, de gedraging van de wederpartij kan reeds onrechtmatig zijn omdat het een meewerken aan een onrechtmatige handeling van de commissaris behelst. In de situatie waarin de commissaris tevens wederpartij van de vennootschap is, zal het gebrek aan goede trouw veelal gegeven zijn. ${ }^{123}$

122. In deze zin met betrekking tot kruiscommissariaten Van der Burg (1986), blz. 300.

123. In gelijke zin Rb. Amsterdam 13 februari 1937, NJ 1938, 348: "O. dat op die wijze het privébelang van gedaagde zozeer rechtstreeks met zijn werkzaamheden als commissaris en de gesties van het bestuur werd verbonden dat van een onpartijdig toezicht geen sprake kon zijn; 0 . dat derhalve voormelde overeenkomst geacht moet worden te zijn in strijd met de goede zeden." 

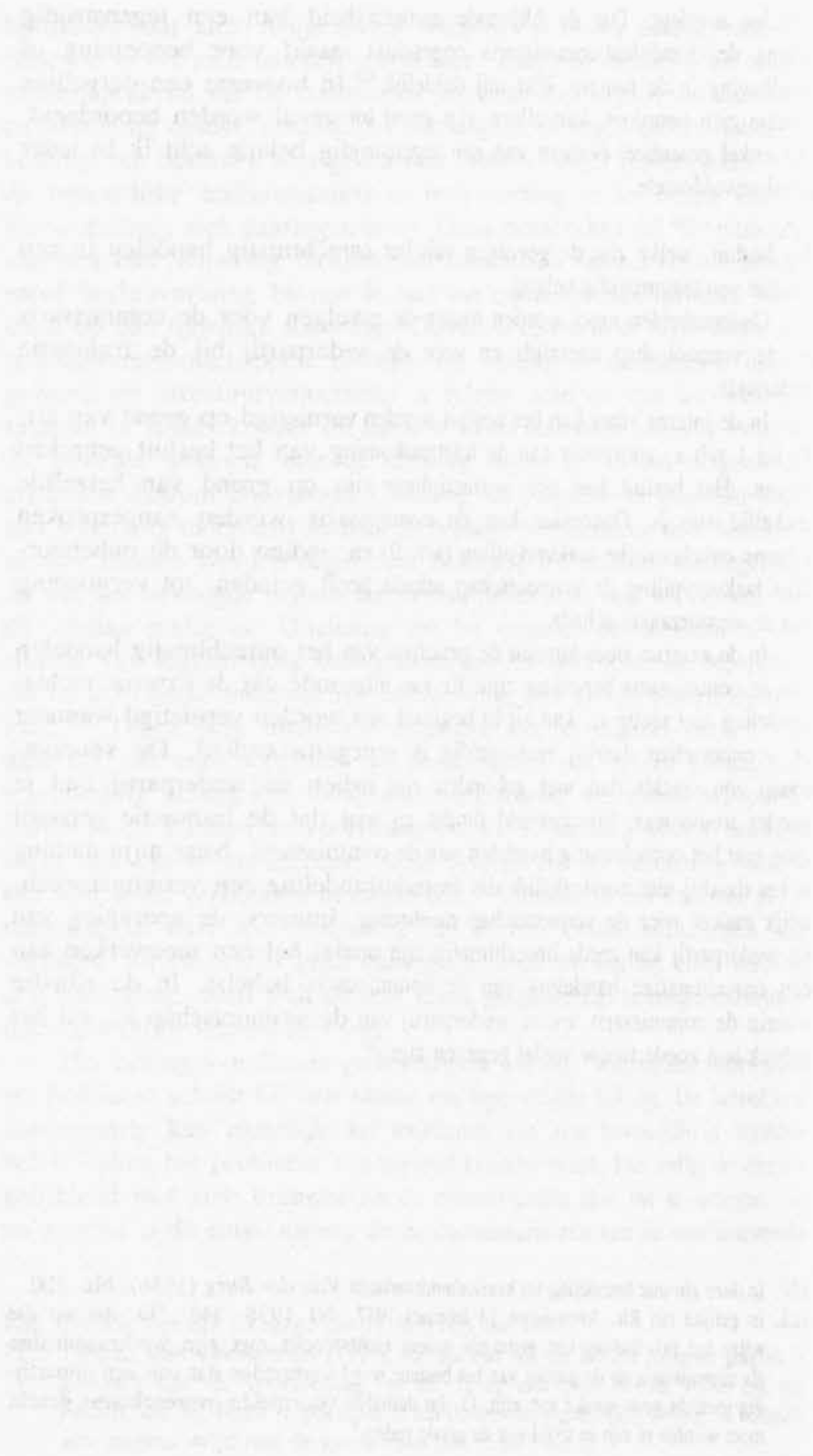


\section{SAMENVATTING}

Geheel duidelijk is de rechtspositie van de raad van commissarissen bij nv en bv niet. In deze studie is een poging gedaan om enkele aspecten van deze positie te verduidelijken.

De raad van commissarissen is een orgaan van de rechtspersoon. In het eerste hoofdstuk is gesteld dat de taak van raad van commissarissen zich richt tot de verwezenlijking van het vennootschappelijke doel. Dit is het doel dat de rechtsgenoten beogen met het tot stand brengen en in stand houden van de vennootschap en dat zijn juridische kristallisatie vindt in het statutair doel. In ons wettelijk systeem heeft de raad van commissarissen "tot taak toezicht te houden op het beleid van het bestuur en op de algemene gang van zaken in de vennootschap en de met haar verbonden onderneming", aldus art. 140/250 lid 2 Boek 2 BW. De toezichthoudende taak van de raad bestaat rechtens hierin dat zijn leden erop toezien dat het vennootschappelijke doel verwezenlijkt wordt.

Gebleken is dat een deel van bovengenoemde onduidelijkheid, naar de mening van de auteur, te wijten is aan de onduidelijkheid die over het wezen van de vennootschap in de Nederlandse juridische literatuur bestaat. Anders dan algemeen wordt geleerd wordt er in deze studie van uitgegaan dat nv en bv geen instituties zijn die 'los staan' van de aandeelhouders. NV en bv zijn veeleer een instrument voor de realisatie van de voornemens van aandeelhouders. Bij nv en bv zal dit doorgaans het exploiteren van een onderneming zijn teneinde een economisch voordeel te behalen. Omdat de vennootschap een instrumenteel karakter heeft, is het belang dat zij dient functioneel ten opzichte van haar doel. Het belang van de vennootschap is dan ook ondergeschikt aan dat van de aandeelhouders. Men kan ook zeggen dat beide belangen samenlopen. Anderzijds kan niet elk belang van de aandeelhouders worden vereenzelvigd met het vennootschappelijk belang. Dit vennootschappelijk belang is, als feitelijke realiteit bezien, in dit onderzoek omschreven als het rechtmatige belang van de aandeelhouders. Indien het vennootschappelijk belang als een juridische categorie verstaan wordt, komt het overeen met de norm van art. 8 Boek 2 BW. Het vennootschappelijk belang is dan de goede trouw die in acht moet worden genomen bij de uitoefening van vennootschappelijke bevoegdheden.

Naast de toezichthoudende taak komt aan de raad van commissarissen volgens de wet een adviserende taak toe. In deze studie is de betekenis van deze taak gerelativeerd.

Voorts kan het college van commissarissen onder omstandigheden worden belast met de bestuurstaak of met een deel daarvan. Het betreft hier 
de vervanging van het bestuur bij belet en ontstentenis (art. 134/244 lid 4 Boek $2 \mathrm{BW}$ ) en de vertegenwoordiging van de vennootschap in geval van tegenstrijdig belang van bestuurders (art. 146/256 Boek 2 BW).

Ten aanzien van de mogelijkheid om statutair aan de raad van commissarissen andere taken toe te kennen is een restrictief standpunt ingenomen.

In het tweede hoofdstuk zijn de bevoegdheden van de raad van commissarissen onderzocht. Twee conclusies uit dit hoofdstuk zijn dat de bestaanbaarheid van prioriteitsrechten in de gebruikelijke vorm naast de raad van commissarissen slechts in beperkte mate mogelijk is -in het bijzonder bij structuurvennootschappen- en dat de beschikking over de leidinggevende ambten de voornaamste bevoegdheid van de raad van commissarissen is.

Aandacht is eveneens besteed aan de samenstelling van de raad van commissarissen. Dit gebeurde in het derde hoofdstuk. In de eerste plaats is een poging gedaan de rechtspositie van de commissaris nader te verklaren. De in de literatuur gangbare verklaring, namelijk dat de commissaris in een contractuele relatie tot de vennootschap staat, welke relatie als een overeenkomst tot het verrichten van enkele diensten of, in de terminologie van het Nieuw BW, 'opdracht' wordt beschouwd, werd niet bevredigend geacht. Gesteld is dat commissarissen als ambtsdragers van de rechtspersoon jegens deze in een vennootschapsrechtelijke verhouding staan die van een andere aard is dan de contractuele verhouding.

In dit derde hoofdstuk is vooral de structuurvennootschap onderwerp van studie geweest. Het structuurregime bevat ten opzichte van het gewone regime een aantal bijzonderheden met betrekking tot de samenstelling van de raad van commissarissen. Ingegaan is op enkele van deze bijzonderheden, zoals de eisen waaraan een kandidaat dient te voldoen om in aanmerking te komen voor benoeming als commissaris, de mogelijkheid tot het stellen van statutaire kwaliteitseisen en de bezwaargronden van art. 158/268 lid 6 Boek 2 BW.

Ter afsluiting van dit hoofdstuk zijn enkele bijzondere gevallen bestudeerd, namelijk die waarin commissarissen om verschillende redenen een bijzondere positie innemen binnen de raad, zoals de president-commissaris, de gedelegeerde commissaris en de overheidscommissaris. Hoewel hij geen lid is van de raad, is ook aandacht besteed aan de figuur van de regeringswaarnemer die, vanwege de bevoegdheden die hem plegen te worden toegekend, een zekere gelijkenis vertoont met de commissaris.

In het vierde en laatste hoofdstuk is de takvervulling van de commissarissen aan de orde gesteld. Daarin is een onderscheid gemaakt tussen de begrippen verantwoordelijkheid en aansprakelijkheid. Het eerste bepaalt 


\section{SAMENVATTING}

hetgeen de commissaris krachtens zijn ambt gehouden is te doen. Het tweede is een mogelijk rechtsgevolg van zijn onbehoorlijke taakvervulling. Gebleken is dat, anders dan algemeen wordt aangenomen, voor ontstaan van ansprakelijkheid niet noodzakelijk is dat aan de commissaris een ernstig verwijt kan worden gemaakt. Verdedigd is dat in deze het algemene aansprakelijkheidsregime op de commissaris analoog van toepassing is, en dat derhalve in beginsel iedere tekortkoming in de nakoming van zijn verplichtingen hem schadeplichtig maakt voor zover de tekortkoming aan zijn schuld te wijten is (art. 74 en 75 Boek 6 BW).

Bestudeerd is voorts de verhouding tussen de aansprakelijkheid ex art. 9 jo. 149/259 en ex art. 138/248 Boek 2 BW. De conclusie is dat het in beide gevallen gaat om een vorm van aansprakelijkheid jegens de rechtspersoon. Genoemde normen verhouden zich tot elkaar als genus en species. De bijzonderheid van art. 138/248 ten opzichte van art. 9 bestaat hierin dat de ansprakelijkheid krachtens eerstgenoemde artikelen een vorm van verzwaarde aansprakelijkheid bevatten voor bepaalde faillissementssituaties.

Tot slot zijn enige criteria ontwikkeld ter oplossing van zogenaamde tegenstrijdig belang situaties. 


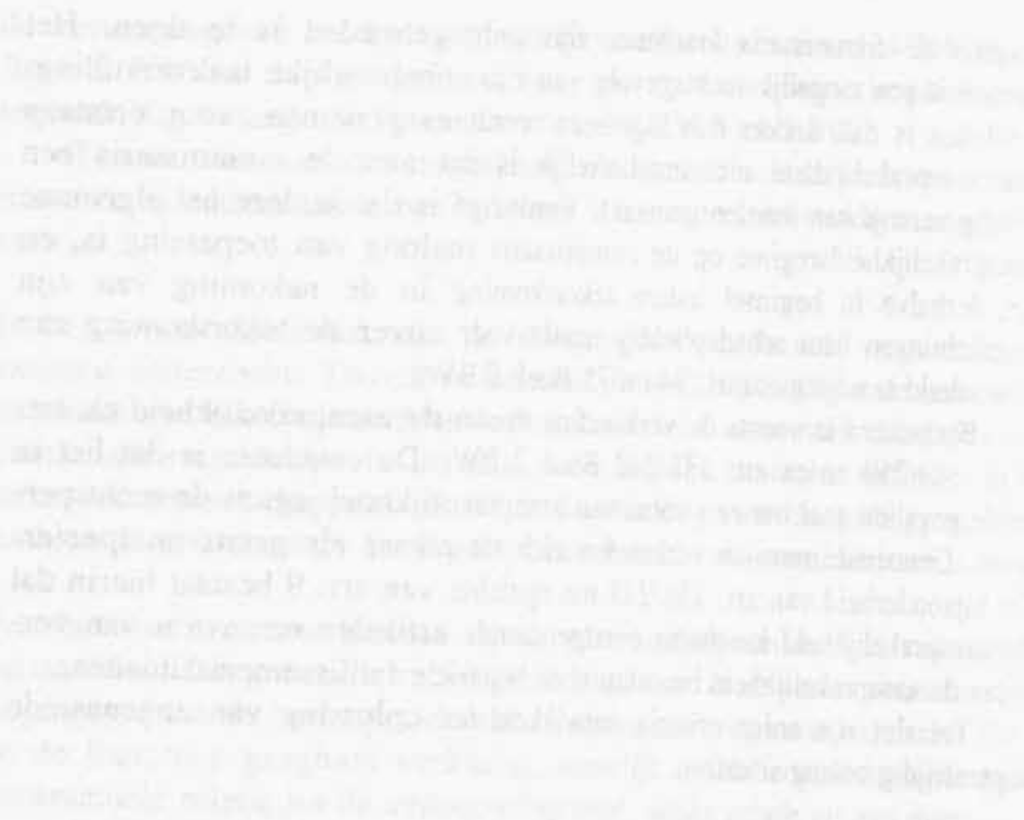




\section{SUMMARY}

The legal position of the board of supervisory directors in Dutch private companies with limited liability ("BV's") and companies limited by shares ("NV's") is not clear. This study attempts to clarify this legal position in several aspects.

The board of supervisory directors is a constituent body of a legal person. The first chapter argues that the task of the board of supervisory directors is aimed at achieving the corporate aims. These are the aims crystallized in legal terms in the aims described in the articles intended by the associates informing and maintaining the company. Under our statutory system the task of the board of supervisory directors is, in the words of Articles 140/250 subsection 2 of Book 2 of the Dutch Civil Code, "to supervise the policy and the management and the general course of affairs of the company and the enterprise connected therewith". The supervisory tasks of the board can be expressed in legal terms in that its members ensure, through there supervision, that the corporate aims are achieved.

It appears, in the author's opinion, that the uncertainties referred to above can be partly attributed to the uncertainties with regard to the corporation in Dutch legal literature. Contrary to the received view, this study is based on the presumption that the NV and BV are not institutions separate from the shareholders. The NV and BV are rather an instrument for achieving the intentions of the shareholders. In the case of an NV and a BV this will generally be the exploitation of an enterprise in order to achieve an economic advantage. Due to the fact that the corporation has an instrumental character, it is important that it serves a functional purpose with regard to its corporate aims. The interests of the corporation are therefor subordinated to those of the shareholders. One can also say that both parties have concurrent interests. However, one cannot regard all interests of the shareholders as being one and the same with the interests of the corporation. Considered in the light of the reality of the facts, these corporate interests are described in this study as the lawful interests of the shareholders. If the corporate interests are recognised to be a legal category, they coincide with the standards laid down in Article 8 of Book 2 of the Dutch Civil Code. The corporate interest is therefor the good faith which must be observed when implementing the corporate powers.

Besides the supervisory task the law lays a advisory task upon the board. In this study the significance of this task has been placed in perspective.

Furthermore, the board of supervisory directors may, under certain 
circumstances, be entrusted with the management tasks or a part thereof. This relates to the replacement of the management in the event of absence or hindrance (Articles 134/244 subsection 2 of Book 2 of the Dutch Civil Code) and the representation of the company in the event of a conflicting interest of managing directors (Articles 146/246 of Book 2 of the Dutch Civil Code).

A restrictive point of view has been adopted in respect of the possibility to award the board of supervisory directors other tasks in the articles and memorandum of association.

The second chapter investigates the powers of the board of supervisory directors. Two conclusions of this chapter are that the existence of shares carrying special powers in their customary form is possible only to a limited degree alongside the board of supervisory directors - especially in large structure corporation - and that the powers to nominate the high management officers are the principal powers of the board of supervisory directors.

Attention is also paid to the composition of the board of supervisory directors. This is done in the third chapter. Firstly, a further explanation of the legal position of a supervisory director is given. It is argued that the customary explanation in legal literature, namely that the supervisory director has a contractual relationship with the company, which is considered as an agreement for the performance of specific services, or a "commission" in the terms of the New Dutch Civil Code, was not satisfactory. It is argued that supervisory directors have a corporate relationship with the company as its officers, and that this corporate relationship is of a different character from that of a contractual relationship.

In this third chapter the primary object of the study is the large structure corporation. The large structure rules contain a number of specific elements in comparison with the ordinary rules with regard to the composition of the board of supervisory directors. Several of these specific elements are examined in more detail, such as the requirements which a candidate must fulfil in order to be eligible to be appointed as a supervisory director, the possibility to lay down qualitative requirements in the articles, and the grounds for objections under Articles 158/268 subsection 6 of Book 2 of the Dutch Civil Code.

This chapter is completed with a study of several special cases, namely those in which supervisory directors occupy a special position on the board for various reasons, such as the Chief Supervisory Director, the Delegated Supervisory Director, and the State Supervisory Director. Although he is not a member of the board attention is also paid to the "State Trustee" who, on account of the powers which are usually awarded 
to him, is similar to a certain extent to the supervisory directors.

The fourth and last chapter examines the performance of the duties of the supervisory directors. A distinction is made between the notions responsibility and liability. The first notion refers to what the supervisory director is obliged to observe by virtue of his office. The second notion is a possible legal consequence of an improper performance of his duties. It appears that, contrary to what is generally assumed, it is not necessary, in order for liability to arise, that the supervisory director is guilty of serious default. The stance is defended that the ordinary standard of care is equally applicable is this respect to the supervisory director, and therefor in principle that all shortcomings in the performance of his obligations impose a duty on him to pay damages, to the extent that the shortcoming can be attributed to his fault ("culpa") (Articles 74 and 75 of Book 6 of the Dutch Civil Code).

A study is also made of the relationship between the liability under Article 9 in conjunction with Articles 149/259 and Articles 138/248 of Book 2 of the Dutch Civil Code. The conclusion is that both cases involve a form of liability towards the legal person. The relationship between these two forms is that of genus and species. The special character of Articles $138 / 248$ in comparison with Article 9 can be found in the circumstance that liability under the first Articles contains a form of extra liability for certain bankruptcy situations.

Finally, several criteria are developed in order to resolve so-called conflict of interest. 


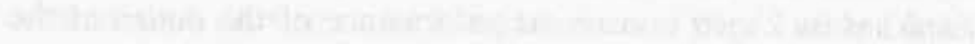

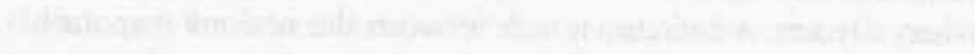

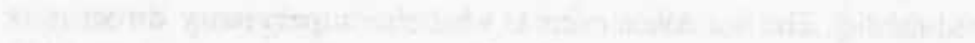

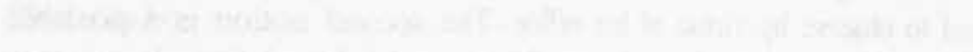

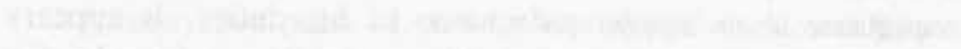

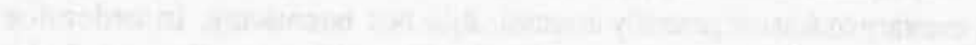

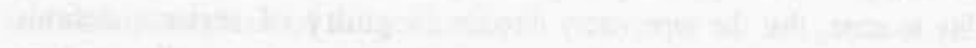

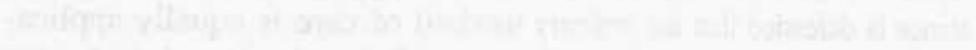

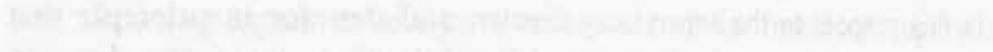

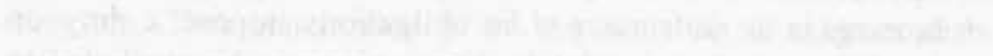
The the

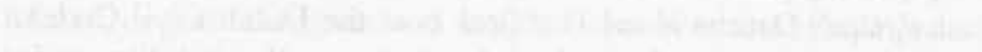

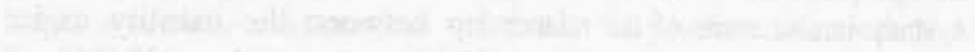

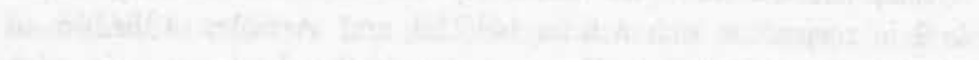

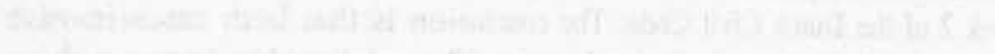

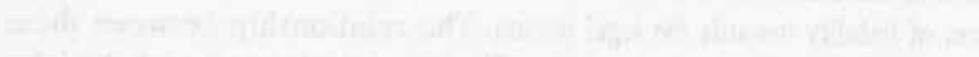

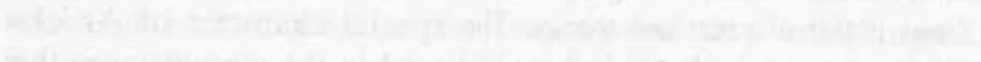

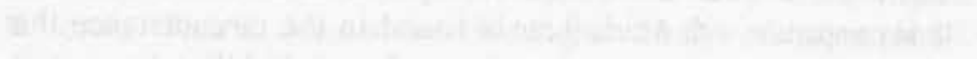

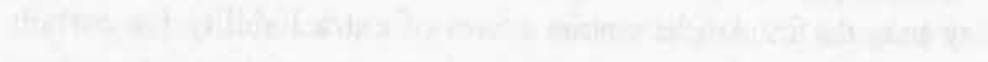




\section{Lijst van aangehaalde jurisprudentie}

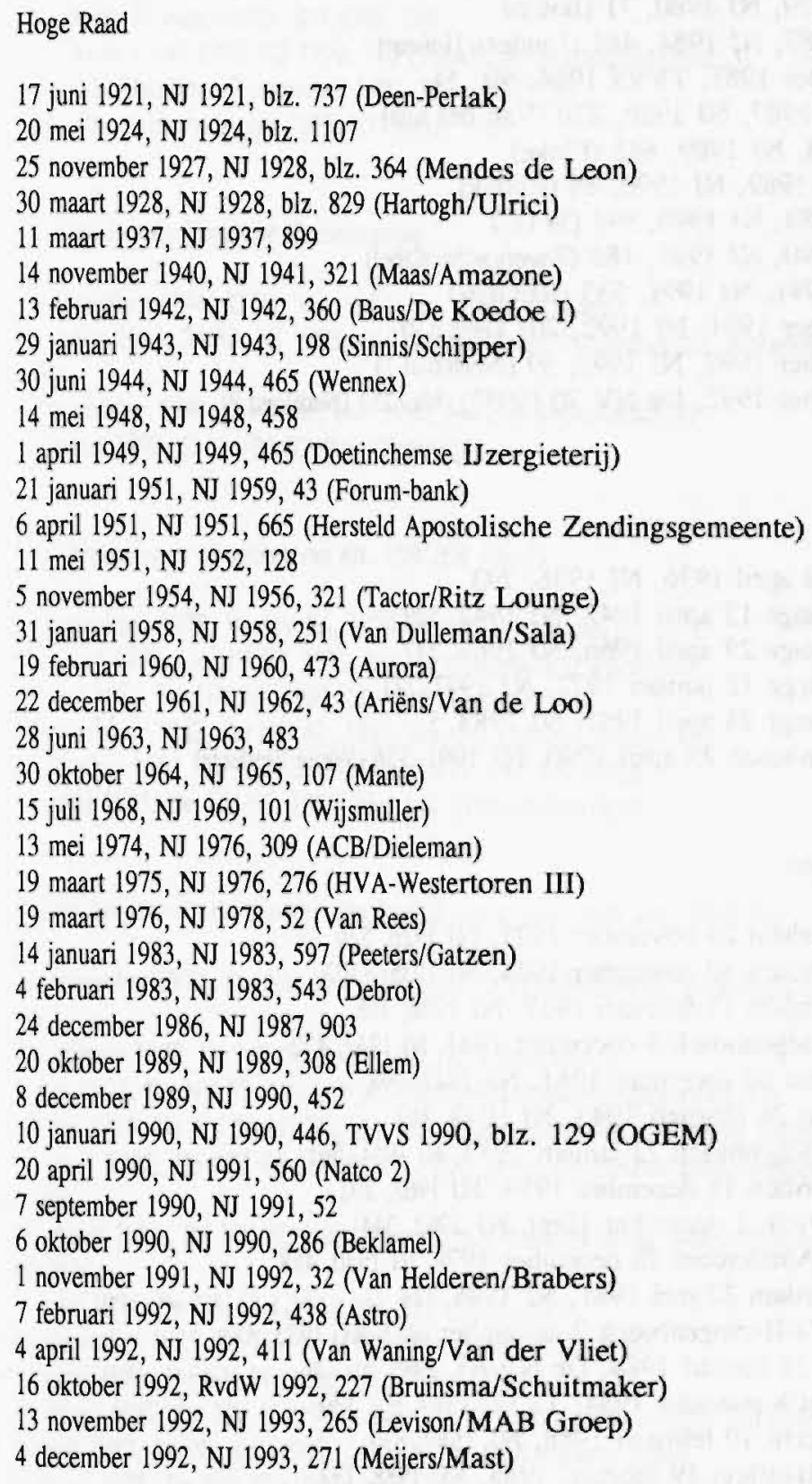


Ondernemingskamer

26 april 1972, NJ 1973, 6

21 juni 1979, NJ 1980, 71 (Batco)

26 mei 1983, NJ 1984, 481 (Linders/Hofstee)

19 december 1985, TVVS 1986, blz. 54

8 oktober 1987, NJ 1989, 270 (Van der Klis)

7 juli 1988, NJ 1989, 845 (Fluke)

2 februari 1989, NJ 1990, 86 (Kodak)

18 mei 1989, NJ 1990, 591 (WTC)

14 juni 1990, NJ 1992, 183 (Twentsche Kabel)

11 april 1991, NJ 1991, 533 (REGEV)

28 november 1991, NJ 1992, 201 (Batco 2)

24 september 1992, NJ 1993, 39 (Nedlloyd 1)

24 september 1992, De NV 70 (1992), blz. 253 (Nedlloyd 2)

\section{Hoven}

Arnhem 29 april 1936, NJ 1936, 793

's-Gravenhage 13 april 1942, NJ 1942, 529

's-Gravenhage 29 april 1966, NJ 1967, 247

's-Gravenhage 12 januari 1972, NJ 1972, 221

's-Gravenhage 24 april 1981, NJ 1983, 5

's-Hertogenbosch 25 april 1990, NJ 1991, 136 (White Products)

\section{Rechtbanken}

Rb. Amsterdam 23 november 1925, NJ 1926, 526

Rb. Amsterdam 30 november 1934, NJ 1935, 1302

Rb. Amsterdam 13 februari 1937, NJ 1938, 348

Rb. 's-Hertogenbosch 5 december 1941, NJ 1942, 432

Rb. Haarlem 30 december 1941, NJ 1942, 798

Rb. Utrecht 24 februari 1943, NJ 1943, 862

Rb. 's-Hertogenbosch 23 januari 1953, NJ 1954, 561

Rb. Amsterdam 16 december 1959, NJ 1962, 202

Rb. Maastricht 1 december 1960, NJ 1962, 344

Pres. Rb. Amsterdam 28 december 1979, NJ 1980, 458

Rb. Amsterdam 27 mei 1981, NJ 1985, 124

Pres. Rb. 's-Hertogenbosch 7 november 1983, KG 1983, 353

Rb. Breda 31 januari 1984, De NV 63, 1985, blz. 31

Rb. Utrecht 8 augustus 1984, TVVS 1987, blz. 130

Rb. Dordrecht 10 februari 1988, NJ 1989, 830

Pres. Rb. Haarlem 19 februari 1988, KG 1988, 133

Rb. Maastricht 21 april 1988, TVVS 1988, blz. 252-253 


\section{RECHTSPRAAK}

Pres. Rb. Dordrecht 28 april 1988, KG 1988, 228

Pres. Rb. 's-Gravenhage 17 mei 1988, KG 1988, 250

$\mathrm{Rb}$. Amsterdam 1 augustus 1988, KG 1988, 341 (HCS 2)

Rb. Breda 31 maart 1989, KG 1989, 204

Rb. Breda 1 mei 1990, NJ 1990, 740 (Tilburgse Hypotheekbank)

Pres. Rb. Haarlem 17 december 1991, KG 1992, 38

Pres. Rb. Arnhem 14 juli 1992, KG 1992, 363

Hof van Justitie Europese Gemeenschap

12 november 1974, 32/74, Jur. 1974, blz. 1201 (Haaga)

22 maart 1983, 34/82, NJ 1983, 644 (Peters/Zuid Nederlandse Aannemersvereniging)

13 november 1990, C-106/89, Jur. 1990, I-4156 (Marleasing)

10 maart 1992, C-214/89 (Duffrijn/Petereit)

SER beslissingen op grond van art. 158/268 (oud)

22 september 1978, De NV 56, 1978, blz. 218 (Lanser)

16 maart 1979, De NV 57, 1979, blz. 94 (Standaard Electric)

26 mei 1982, De NV 60, 1982, blz. 215 (Holec)

19 november 1982, De NV 61, 1983, blz. 56 (Mobil Oil B.V.)

21 oktober 1983, De NV 62, 1984, blz. 111-112 (Amfas)

11 april 1985, De NV 63, 1985, blz. 144 (Streekvervoer)

Beschikkingen van de minister van Justitie op grond van art. 156/266

13 november 1973, De NV 52 (1974), blz. 9 (Bouwfonds Nederlandse Gemeenten)

28 februari 1978, De NV 56 (1978), blz. 70 (PLEM)

1 mei 1978, De NV 52 (1974), blz. 105, (Nederlandse Spoorwegen)

18 juli 1978, De NV 56 (1978), blz. 168 (Bank voor Nederlandse Gemeenten)

15 april 1982, De NV 66 (1988), blz. 106 (Elektriciteitsmaatschappij IJsselcentrale)

21 maart 1984, De NV 62 (1984), blz. 226 (Waterleiding Maatschappij Overijssel N.V.)

16 mei 1984, De NV 63 (1985), blz. 127 (Obragas)

16 december 1985, De NV 66 (1988), blz. 108 (PLEM II)

24 april 1986, De NV 64 (1986), blz. 176 (SEP)

23 maart 1987, De NV 65 (1987), blz. 251 (Electriciteitsbedrijf Zuid-Holland)

7 april 1987, De NV 66 (1988), blz. 31 (De Porceleyne Fles)

8 maart 1988, De NV 67 (1989), blz. 18 (Electriciteits-Maatschappij Ijsselcentrale) 
2 juni 1989, De NV 69 (1991), blz. 262 (SEP)

24 oktober 1989, De NV 69 (1991), blz. 265 (Flevolandse Drinkwater Maatschappij)

6 maart 1990, De NV 69 (1991), blz. 290 (Provinciale Gelderse Energie Maatschappij) 


\section{Lijst van geraadpleegde literatuur}

Allen, C.K., Law in the making, 7th. ed., Oxford 1966.

Asser-Van der Grinten I, C. Asser's Handleiding tot de beoefening van het $\mathrm{Ne}$ derlands Burgerlijk Recht, De Vertegenwoordiging, door W.C.L. van der Grinten, zevende druk 1990.

Asser-Van der Grinten II, C. Asser's Handleiding tot de beoefening van het Nederlands Burgerlijk Recht, De Rechtspersoon, door W.C.L. van der Grinten, zevende druk 1991.

Asser-Hartkamp II, C. Asser's Handleiding tot de beoefening van het Nederlands Burgerlijk Recht, Algemene leer der overeenkomsten, door A.S. Hartkamp, achtste druk 1989.

Bak, G.G.M., Commissaris en accountant, TVVS 1982, blz. 29.

Bartman, S.M., Over décharge, in het bijzonder bij de eenmansvennootschap, WPNR 5958 (1990), blz. 269.

Bartman, S.M., Ziek zijn en ontslagen worden. Over de psyschische belasting van een bestuurder, NJB 1993, blz. 825 .

Belinfante (1929), Ontwerpen van wetten op de vennootschappen en andere, 'sGravenhage 1929.

Boer, H. de (1988), De toezichthoudende taak van commissarissen, TVVS 1988, blz. 1.

Boukema, C.A., Civielrechtelijk rechtspraakoverzicht, TVVS 1975, blz. 169.

Boukema, C.A. (1992), Samenloop, Monografieën Nieuw BW, A21, Deventer 1992.

Brunner, C.J.H., Aansprakelijkheid naar draagkracht, Rede Groningen, Deventer 1973.

Burg, V.A.M, van der (1976), De van overheidswege benoemde commissaris, WPNR 5371 (1976), blz. 755.

Burg, V.A.M. van der, De regeringscommissaris, TVVS 1977, blz. 329.

Burg, V.A.M. van der (1981), Invoering van werknemerscommissarissen bij de structuurvennootschap?, TVVS 1981, blz. 236.

Burg, V.A.M. van der (1982), Informatieverschaffing aan commissarissen van NV of BV, TVVS 1982, blz. 241.

Burg, V.A.M. van der, De dubbele eis van Nederlanderschap en ingezetenschap voor commissarissen ener structuur-N.V. of -B.V., WPNR 5610 (1982), blz. 349.

Burg, V.A.M. van der (1983), De regeringswaarnemer, TVVS 1983, blz. 329.

Burg, V.A.M. van der (1985), Nogmaals: de van overheidswege benoemde commissaris, WPNR 5758 (1985), blz. 693.

Burg, V.A.M. van der, Het presidium van de Raad van Commissarissen bij een NV of BV, TVVS 1985, blz. 68 . 
Burg, V.A.M. van der (1986), Het vraagstuk van de kruiscommissariaten bij structuurvennootschappen, TVVS 1986, blz. 298.

Burg, V.A.M. van der (1990), Een statutaire commissie van advies bij een structuurvennootschap, TVVS 1990, blz. 65 en 289.

Burgert, R. / Timmerman, C.W.A. / Joosten, H.F.J., De jaarrekening nieuwe stijl, 6de druk, Alphen a/d Rijn, 1990.

Castro y Bravo, F. de, Derecho Civil de España, Madrid 1949 (reimpr. 1984).

Commissie Verdam, Herziening van het ondernemingsrecht. Rapport van de commissie ingesteld bij beschikking van de Minister van Justitie van 8 april 1960, Staatsuitgeverij, 's-Gravenhage 1965.

Cremers, J.H.F.J.(1971), Prioriteitensaandelen, Diss. Nijmegen, Deventer 1971. Delfos-Roy, Y.L.L.A.M., Toetsing en vergaring van informatie door de raad van commissarissen, TVVS 1992, blz. 224.

Dlez Picazo, L. , La representación en el derecho privado, Madrid 1979.

Dorresteijn, A.F.M. (1989), Tegenstrijdig belang van bestuurders en commissarissen, Uitgaven vanwege het instituut voor ondernemingsrecht, Rijksuniversiteit Groningen, nr. 8, Deventer 1989.

Dortmond, P.J. (1977), Het meerderheidsbeginsel en het voorkomen van een impasse bij het staken der stemmen in aandeelhoudersvergaderingen, WPNR 5410 (1977), blz. 641.

Dortmond, P.J. (1986), Aansprakelijkheid voor belasting- en premieschulden van de rechtspersoon, in: De nieuwe misbruikwetgeving, Uitgaven vanwege het instituut voor ondernemingsrecht, Rijksuniversiteit Groningen, nr. 2, Deventer 1986, blz. 41 .

Dortmond, P.J. (1990), Misbruik van rechtspersonen, in: Piercing Van Schilfgaarde, Uitgaven vanwege het instituut voor ondernemingsrecht, Rijksuniversiteit Groningen, nr. 9, Deventer 1990, blz. 13.

Drion, T. (1993), Werknemer bij de moeder en commissaris bij de dochter, in: De dubbelrol in het vennootschapsrecht, Uitgaven vanwege het instituut voor ondernemingsrecht, Rijksuniversiteit Groningen, nr. 16, Deventer 1993, blz. 87.

Duden, K., Überwachung: wen oder was?, FS Fischer, Berlin 1979, blz. 95.

Duk, R.A.A., Boekbespreking: J.B. Huizink, Bestuurders van rechtspersonen, W PNR 5958 (1990), blz. 273.

Eisma, S.E. (1993), De commissaris in een dubbelrol, in: De dubbelrol in het vennootschapsrecht, Uitgaven vanwege het instituut voor ondernemingsrecht, Rijksuniversiteit Groningen, nr. 16, Deventer 1993, blz. 33.

Eykman, L.G. (1986), De aansprakelijkheid van directeuren en commissarissen tegenover de vennootschap, bezien vanuit algemeen civielrechtelijke beginselen, TVVS 1986 , blz. 87.

Fikentscher, W. (1974), Maurice Hauriou und die institutionelle Rechtslehre, FS L. Raiser, Tübingen 1974, blz. 559.

Fleck, H.-J. (1991), Eigengeschäfte eines Aufsichtsratsmitglieder, FS Heinsius, Berlin 1991, blz. 89.

Flume, W. (1979), Allgemeiner Teil des Bürgerlichen Rechts, Zweiter Band, Das Rechtsgeschäft, 3. Auf., Berlin 1979.

Flume, W. (1983), Allgemeiner Teil des Bürgerlichen Rechts, Erster Band, 


\section{LITERATUUR}

Zweiter Teil, Die juristische Person, Berlin 1983.

Freijters, Jer.Ph.M., Tegenstrijdig belang, De NV 42 (1964-65) blz. 57.

Gaay Fortman, W.F. de (1968), Taak, bevoegdheden en verantwoordelijkheden van de organen in de n.v., De NV 46 (1968-69), blz. 185.

Geersing, B., Een misverstand met betrekking tot de raad van commissarissen?, TVVS 1979, blz. 17.

Geerts, P.G.F.A. (1988), Het door commissarissen ex art. 134 (244) lid 4 Boek 2 BW tijdelijk voorzien in het bestuur van de vennootschap, De NV 66 (1988), blz. 101 .

Geßler, Aktiengesetz, Kommentar von E. Geßler / W. Hefermehl / U. Eckardt / B. Kropff, München 1973, 1974.

Giltay Veth, N.J.P., De bezoldiging van commissarissen, TVVS 1972, blz. 145.

Giltay Veth, N.J.P., De rechtspositie van bestuurder en commissaris bij NV en BV, Offerhauskring 25 jaar, Deventer 1987, blz. 64.

Glasz, J.R. (1982), De commissaris: meer verantwoordelijkheid en aansprakelijkheid, TVVS 1982, blz. 33.

Glasz, J.R. (1986), Aansprakelijkheid van directeuren en commissarissen vanuit het vennootschapsrecht bezien, TVVS 1986, blz. 81 .

Glasz, J.R. (1991), De overheidscommissaris heeft het moeilijk, NJB 1991, blz. 1541.

Glasz, J.R. (1992), De commissaris. Aanbevolen gedragsregels, 2de druk, Deventer 1992.

Graaf, P.S. de (1974), Van tot naar omtrent, TVVS 1974, blz. 225.

Grinten, W.C.L. van der, Uitgifte van nieuwe aandelen en voorkeursrecht, De NV 27 (1949-50), blz. 121.

Grinten, W.C.L. van der, De bevoegdheidssfeer van de commissaris, De NV 26 (1948-49), blz. 113.

Grinten, W.C.L. van der, De miskende commissaris, De NV 30 (1952-53), blz. 41.

Grinten, W.C.L. van der, Overpeinzingen, De NV 46 (1968-69), blz. 187.

Grinten, W.C.L. van der (1976), Contractuele bedingen omtrent inrichting en structuur van n.v. en b.v., De NV 54 (1976), blz. 73.

Grinten, W.C.L. van der, Noot onder bindend advies d.d. 27 december 1976, De NV 55 (1977), blz. 109.

Grinten, W.C.L. van der (1979), Taak en bevoegdheden van de vennootschapsorganen ten aanzien van de jaarrekening, De NV 57 (1979), blz. 18.

Grinten, W.C.L. van der, Organen van een rechtspersoon, De NV 57 (1979), blz. 139.

Grinten, W.C.L. van der (1981), Juridische aspecten van de totstandkoming van de jaarrekening; publikatieplicht, in: De jaarrekening en de Vierde EEG-Richtlijn, Serie Monografieën vanwege het Van der Heijden-Instituut, deel 20, Deventer 1981, blz. 35 .

Grinten, W.C.L. van der (1982), De mythe van de aansprakelijkheid, De NV 60 (1980), blz. 201.

Grinten, W.C.L. van der (1983), Philips als dwaallicht, De NV 61 (1983), blz. 157; 62 (1984), blz. 108. 


\section{LITERATUUR}

Grinten, W.C.L. van der, Reactie op Hoom / Dekker, De NV 61 (1983), blz. 217.

Grinten, W.C.L. van der, De nieuwe misbruikwetgeving, De NV 64 (1986), blz. 19.

Grinten, W.C.L. van der, Gedragsregels voor commissarissen, De NV 65 (1987), blz. 62 .

Grinten, W.C.L. van der (1987), Decharge en kwijting in het vennootschapsrecht, De NV 65 (1987), blz. 99.

Grinten, W.C.L. van der, Arbeidsovereenkomstenrecht, 14de druk, Alphen aan de Rijn 1987.

Grinten, W.C.L. van der (1990), Structuurregeling als beschermingsconstructie, in: Beschermingsconstructies, Serie Monografieën vanwege het Van der HeijdenInstituut, deel 34, Deventer 1990, blz. 13.

Grinten, W.C.L. van der, Ontslag van een zieke bestururder, De NV 71 (1993), blz. 48 .

Groefsema, L., Bevoegd beschikken over andersmans recht, Diss. Groningen, Deventer 1993.

Groot, H. de (1986), Misbruik en kennelijk onbehoorlijk bestuur, NJB 1986, blz. 1307.

Groot, H. de (1993), Bestuurdersaansprakelijkheid, Deventer 1993.

Grosheide, D.W.O.A. (1969), De commissaris, preadvies van de broederschap van candidaat-notarissen, Groningen 1969.

Grosheide, G.H.A. (1954), Décharge in het bijzonder bij Naamloze Vennootschappen, De NV 32 (1954-55), blz. 81.

Grosheide, G.H.A., Het Commissariaat in de Naamloze Vennootschap, De NV 36 (1958-59), blz. 122.

Haardi, W.L. (1969), De commissaris, preadvies van de broederschap van candidaat-notarissen, Groningen 1969.

Handboek, E.J.J. van der Heijden / W.C.L. van der Grinten, Handboek voor de naamloze en de besloten vennootschap, 12de druk, Zwolle 1992.

Haren, l. van, Wezen en doel van de moderne onderneming, De NV 40 (196263), blz. 180.

Haren, I.A.C. van (1977), De onafhankelijkheid en onpartijdigheid van Structuurwet-commissarissen, TVVS 1977, blz. 129.

Hauriou, M. (1925), La théorie de l'institution et de la fondation, Cahiers de la Nouvelle Journée, nr. 4, Paris 1925.

Heijden, E.J.J. van der, De ontwikkeling van de naamloze vennootschap in Nederland voor de codificatie, diss. 1908.

Hellema, H.J. (1965), De functie van de commissaris in de naamloze vennootschap, Serie Belastingconsulentendag no. 10, Amsterdam 1965.

Hellema, H.J. (1970), De raad van Commissarissen, De NV 48 (1970-71), blz. 123.

Hoek, P.C. van den (1986), Aansprakelijkheid bij faillissement van de rechtspersoon, in: De nieuwe misbruikwetgeving, Uitgaven vanwege het instituut voor ondernemingsrecht, Rijksuniversiteit Groningen, nr. 2, Dèventer 1986, blz. 61 . Hoek, P.C. van den (1991), Variaties op de structuurregeling bij contract, in: 


\section{LITERATUUR}

Ondernemingsrechtelijke contracten, Uitgaven vanwege het instituut voor ondernemingsrecht, Rijksuniversiteit Groningen, nr. 14, Deventer 1991, blz. 81 . Hoek, P.C. van den (1992), De toekomst van de structuurregeling, TVVS 1992, blz. 275.

Honée, H.J.M.N. (1979), De benoeming van commissarissen bij grote vennootschappen, Serie Monografieën vanwege het Van der Heijden-Instituut, deel 19, Deventer 1979.

Honée, H.J.M.N. (1983), De regeringswaarnemer en de vennootschappelijke organisatie, Rede Nijmegen, Deventer 1984.

Honée, H.J.M.N. (1984), De overheidscommissaris en de norminstructie van het vennootschappelijk belang, Van der Grinten-bundel, Zwolle 1984, blz. 105.

Honée, H.J.M.N., Contacten tussen commissarissen en ondernemingsraad, Serie Monografieën vanwege het Van der Heijden-Instituut, deel 26, Deventer 1987.

Hoorn, Th. P. van / Dekker, H.C., Verantwoording door de Raad van Commissarissen van structuurvennootschappen, De NV 61 (1983), blz. 145.

Huizink, J.B. (1989), Bestuurders van rechtspersonen, Diss. Groningen, Deventer 1989.

Ingh, F.J.P. van den, Naar een uitbreiding van de bevoegdheden van de aandeelhouderscommissie?, WPNR 6068 (1992), blz. 805.

Ingh, F.J.P. van den, Het ongehoorde ontslag van een bestuurder, WPNR 6095 (1993), blz. 457.

Kamphuisen, P.W., De rechtsverhouding tusschen de naamloze vennootschap en haar commissaris, De NV 22 (1944-45), opgenomen in: Verzameld werk van Prof. Mr. P.W. Kamphuisen, Zwolle 1963, blz. 471.

Kamphuisen, P.W., De gedelegeerde commissaris en het begrip bestuurder, De NV 34 (1956-57), blz. 41.

Kamphuisen, P.W., De rechtsverhouding tussen directeur en N.V., De NV 26 (1948-49), opgenomen in: Verzameld werk van Prof. Mr. P.W. Kamphuisen, Zwolle 1963, blz. 485.

Kelsen, H., Allgemeine Staatslehre, Berlin 1925.

Klamer, A.F., Duurverlenging van Rechtspersonen exit, WPNR 6071 (1992), blz. 875 .

Kluiver, H.J. / Schwar, C.A., Vertegenwoordiging van rechtspersonen en de betekenis van de wettelijke bevoegdheidsbeperkingen, TVVS 1993, blz. 85.

Kluiver, H.J. de, Onderhandelen en privaatrecht, Deventer 1992.

Knol, H.D.M. (1936), Civielrechtelijke aansprakelijkheid van directie en commissarissen van naamlooze vennootschappen volgens nederlandsch recht, Diss. Amsterdam, Zwolle.

Kölner Kommentar, Kölner Kommentar zum Aktiengestz, W. Zöllner e.a., Köln 1985.

Kortmann, S.C.J.J., Interne draagplicht en regres, in: Serie Monografieën vanwege het Van der Heijden-Instituut, deel 37, Deventer 1991, blz. 53.

Kortmann, S.C.J.J. (1993), De curator, de bewindvoerder en de organen van de vennootschap en onderneming, in; Het faillissement in de tijd van Molengraaff en nu, Preadvies van de Vereniging 'Handelsrecht', Zwolle 1993.

Larenz, K. (1987), Lehrbuch des Schuldrechts, Erster Band, Allgemeiner Teil, 


\section{LITERATUUR}

14. Auf., München 1987.

Larenz, K. (1989), Allgemeiner Teil des deutschen bürgerlichen Rechts, 7. Auf., 1989.

Larenz, K. (1991), Methodenlehere der Rechtswissenschaft, 6. Auf., Berlin 1991.

Leeuwen, B.H.A. van, Verstrengeling van belangen en het vennootschapsrecht, TVVS 1987, blz. 29.

Leeuwen, B.H.A. van (1990), Beginselen van behoorlijk ondernemingsbestuur, Uitgaven vanwege het instituut voor ondernemingsrecht, Rijksuniversiteit Groningen, nr. 10, Deventer 1990.

Löwensteyn, F.J.W. (1959), Wezen en bevoegdheid van het bestuur van de vereniging en de naamloze vennootschap, Diss., Zwolle 1959.

Löwensteyn, F.J.W. (1970), De naamloze vennotschap als raakpunt van contraire belangen, in: 100 jaar rechtsleven, De NJV 1870-1970, Zwolle 1970, blz. 85.

Löwensteyn, F.J.W. (1983), De positie van het bestuur in de tweede golf, TVVS 1983, blz. 173.

Löwensteyn, F.J.W. (1985), Wezen en bevoegdheid van het bestuur van de vereniging en de naamloze vennootschap, AA 34 (1985), blz. 720.

Lubbers, A.G. (1973), De algemene vergadering van aandeelhouders en de benoeming van commissarissen, in: De nieuwe structuur van de grote N.V. en B.V., Serie Monografieën vanwege het Van der Heijden-Instituut, deel 9, Deventer 1973, blz. 45.

Lutter, M. (1981), Bankvertreter im Aufsichtsrat, ZHR 1981, blz. 224.

Lutter, M. / Krieger, G (1989), Rechte und Pflichten des Aufsichtsrats, 2 Auf., Freiburg i. Br. 1989.

Lutter, M. / Kremer, T., Die Beratung der Gesellschaft durch Aufsichtsratsmitglieder. Bemerkungen zur Entscheidung BGHZ 114, 127 ff, ZGR 1992, blz. 87.

Maeijer Wetsgeschiedenis, Losbladige Bundel Naamloze en Besloten Vennootschap, onder redactie van J.M.M. Maeijer.

Maeijer, J.M.M. (1964), Het belangenconflict in de Naamloze Vennootschap, Rede Nijmegen, Deventer 1964.

Maeijer, J.M.M., Aandeelhouders in een n.v. en de eisen van de goede trouw, De NV 42 (1964-65), blz. 153.

Maeijer, J.M.M. (1972), Herbezinning op de functie van commissarissen, in: Het nieuwe vennootschapsrecht, Serie Monografieën vanwege het Van der HeijdenInstituut, deel 7, Deventer 1972, blz. 27.

Maeijer, J.M.M. (1973), De verdeling van bevoegdheden tussen de diverse organen; oligarchische regelingen, in: De nieuwe structuur van de grote N.V. en B.V., Serie Monografieën vanwege het Van der Heijden-Instituut, deel 9, Deventer 1973, blz. 15.

Maeijer, J.M.M., Ondernemingskamer-beschikkingen en 'enquêterecht', AA 1974, blz. 118.

Maeijer, J.M.M. (1976), De stemovereenkomst van aandeelhouders, Van der Ploeg-bundel, Zwolle 1976, blz. 95.

Maeijer, J.M.M. (1986), Misbruik van vennootschappen door bestuurders en onrechtmatige daad, Liber Amicorum J. Ronse, Brussel 1986, blz. 277. 


\section{LITERATUUR}

Maeijer, J.M.M. (1989), 25 jaren belangenconflict in de Naamloze Vennootschap, De NV 67 (1989), blz. 1.

Maeijer, J.M.M., M.M. Mendel: Het vennootschappelijk belang, mede in concernverband beschouwd, Boekbespreking, RM Themis 1990, blz. 465 .

Maeijer, J.M.M. (1991), Persoonlijke aansprakelijkheid van bestuurders en commissarissen; wanbeleid van rechtspersonen, in: Serie Monografieën vanwege het Van der Heijden-Instituut, deel 37, Deventer 1991, blz. 3.

Maeijer, J.M.M. (1993), Bestuurders en tegenstrijdig belang, in: De dubbelrol in het vennootschapsrecht, Uitgaven vanwege het instituut voor ondernemingsrecht, Rijksuniversiteit Groningen, nr. 16, Deventer 1993, blz. 11.

Meijers, E.M. (1923), Aansprakelijkheid en décharge van directeuren van naamlooze vennootschappen, rede gehouden op 29 september 1923, Purmerend.

Mendel, M.M. (1971), Het statutaire doel van de naamloze vennootschap, Diss. Leiden, Deventer 1971.

Mendel, M.M. (1989), Het vennootschappelijk belang, mede in concernberband beschouwd, Rede Leiden, Deventer 1989.

Mengelberg, R.H.W., Een manier van doen, TVVS 1978, blz. 201.

Mohr, A.L. (1993), De dubbelrol aandeelhouder-bestuurder, in: De dubbelrol in het vennootschapsrecht, Uitgaven vanwege het instituut voor ondernemingsrecht, Rijksuniversiteit Groningen, nr. 16, Deventer 1993, blz. 73.

Oderkerk, H.W.J.M., Ontslag van de zieke bestuurder, De NV 69 (1991), blz. 285.

Ophof, H.P.J. (1988), Gedragsregels commissarissen, Slagter-bundel, Deventer 1988, blz. 189.

Paillusseau, J., La société anonyme, technique d'organisation de l'enterprise, Paris 1967.

Raaijmakers, M.J.G.C., Rechtspersonen tussen contract en instituut, Rede Tilburg, Deventer 1987.

Raaijmakers, M.J.G.C. (1990), Over interne en externe aansprakelijkheid van bestuurders en toezichthouders van rechtspersonen en vennootschappen, in: Aansprakelijkheden, uitgave van het Nederlands genootschap van Bedrijfsjuristen 1930-1990, Deventer 1990, blz. 159.

Raaijmakers, M.J.G.C. (1991), Over taák en verantwoordelijkheid van commissarissen, Langman-bundel, Deventer 1991, blz. 173.

Raiser, T., Weisungen an Aufsichtsratsmitglieder?, ZGR 1978, blz. 391.

Rechtspersonen, Losbladige bundel, geciteerd naar de bewerker.

Renard, G., La Théorie de l'Institution, Paris 1930.

Rheinstein, M., Review: The Jurisprudence of Interests, Journal of Legal Education 1 (1948-49), blz. 472, opgenomen in Collected Works, Tübingen 1979 , blz. 176.

Ritmer, F., Wirtschaftsrecht, Karlsruhe 1979.

Roelvink, H.L.J., Rechtsbescherming van directeuren, NJB 1981, blz. 75.

Rood, M.G. (1989), De werknemer als directeur van een structuurvennootschap, Slagter-bundel, Deventer 1989, blz. 225.

Saenz, J.C., El objeto social en la sociedad anónima, Madrid 1990.

Sanders, $P$., Nieuwe wijn in oude zakken, TVVS 1971, blz. 50. 


\section{LITERATUUR}

Sanders, P. / Westbroek W. (1991), BV en NV, Het nieuwe ondernemingsrecht, bewerkt door F.K. Bruijn en P.M. Storm, zesde druk, Deventer 1991.

Schellekens, J.A., De leer over de "institution" bij M.Hauriou, Nijmegen 1945.

Schilfgaarde, P. van, Vrijheid van vennootschap, s'Jacob-bundel, Zwolle 1975, blz. 247.

Schilfgaarde, $P$. van, Boekbespreking Asser-Van der Grinten II (De Rechtspersoon) 5e druk, De NV 59 (1981), blz. 9.

Schilfgaarde, $P$. van (1984), Geschillen bij de toepassing van de structuurregeling, in: Geschillen in de onderneming, Uitgaven vanwege het instituut voor ondernemingsrecht, Rijksuniversiteit Groningen, nr. 1, Deventer 1984, blz. 1.

Schilfgaarde, P. van (1984b), Noot onder HR 14 januari 1983, NJ 1983, 597 (Peeters/Gatzen), AA 1984, blz. 220.

Schilfgaarde, $P$. van, Boekbespreking: H.J.M. Honée, De regeringswaarnemer en de vennootschappelijke organisatie, NJB 1984, blz. 1264.

Schilfgaarde, $P$. van (1986), Misbruik van rechtspersonen: commentaar op de tweede en derde misbruikwet, Uitgaven vanwege het instituut voor ondernemingsrecht, Rijksuniversiteit Groningen, nr. 3, Deventer 1986.

Schilfgaarde, $P$. van (1987), De interne aansprakelijkheid van bestuurders, Bakels-bundel, Deventer 1987, blz. 267.

Schilfgaarde, P. van, Vennootschapsrecht na 27 jaren, Slagter-bundel, Deventer 1989 , blz. 253.

Schilfgaarde, $P$. van, Naschrift bij S.M. Bartman, Over décharge, in het bijzonder bij de eenmansvennootschap, WPNR 5958 (1990), blz. 273.

Schilfgaarde, $P$. van (1991), Contractuele structurering van bestuur en toezicht, in: Ondernemingsrechtelijke contracten, Uitgaven vanwege het instituut voor ondernemingsrecht, Rijksuniversiteit Groningen, nr. 14, Deventer 1991, blz. 11.

Schilfgaarde, P. van (1992), Van de BV en de NV, negende druk, Arnhem 1992.

Schilfgaarde, P. van, Ontslag van een bestuurder, WPNR 6093 (1993), blz. 389.

Schmidt, K., Gesellschaftsrecht, 2 Auf., Köln 1991.

Schoiten, Th.M., De Commissarisfunctie, De NV 36 (1958-59), blz. 10.

Scholten, Y. (1976), De commissaris, Van der Ploeg-bundel, Zwolle 1976, blz. 127.

Schoordijk, H.C.F., Als vertegenwoordiger van wie treedt de faillissementscurator op? een niet alijd even ongevaarlijke vraagstelling!, Van der Grinten-bundel, Zwolle 1984, blz. 531.

Schut, G.H.A., De commissaris en zijn plaats in de n.v., Publicaties van de NPM, Amsterdam 1962.

Schut, G.H.A., Het wonder van Den Haag, Verdam-bundel, Deventer 1971, blz. 307.

Schwark, E., Zum Haftungsmaßtab der Aufsichtsratmitglieder einer AG, FS W. Wermer, Berlin 1984, blz. 841.

Schwar, C.A., Ontslag van de krachtens arbeidsovereenkomst werkzame bestuurder en het BBA 1945, NJB 1982, blz. 328.

Schwarz, C.A., Boekbespreking: A.F.M. Dorresteijn, Tegenstrijdig belang van bestuurders en commissarissen, WPNR 5989 (1991), blz. 49. 


\section{LITERATUUR}

Schwar, C.A., Het ontslag van de op arbeidsovereenkomst werkzame bestuurder van een vereniging, Stichting en Vereniging 1993, blz. 57.

Slagter, W.J., Macht en onmacht van de aandeelhouder, Rede Rotterdam 1988.

Slagter, W.J. (1990), Compendium van het Ondernemingsrecht, 5de druk, Deventer 1990.

Slagter, W.J., Commentaar op HR 20 oktober 1989, NJ 1989, 308 (Ellem), TVVS 1991, blz. 188.

Smit, H.J., Ontslag en schorsing van directeuren en de mogelijkheid van herstel der dienstbetrekking via kort geding, WPNR 5817 (1987). blz. 89.

Staudinger / Coing, J. von Staudingers Kommentar zum Bürgerlichen Gesetzsbuch, 12., neubearbeitete Auflage 1980, Allgemeiner Teil, Berlin 1980.

Teldersstichting, Prof. Mr. B.M., De raad van commissarissen in de onderneming van morgen, Geschrift nr. 38, 1981.

Timmerman, $L$., Het vennootschapsrecht en het ontslag van een bestuurder van een NV of BV, De NV 63 (1985), blz. 6.

Timmerman, $L$., De stand van het vennootschapsrecht, Rede Groningen, Deventer 1990.

Timmerman, L. (1990), Onderneming en vennootschap, in: Piercing Van Schilfgaarde, Uitgaven vanwege het instituut voor ondernemingsrecht, Rijksuniversiteit Groningen, nr. 9, Deventer 1990, blz. 3 .

Timmerman, L. (1991), De nieuwe algemene bepalingen van boek $2 \mathrm{BW}$, Preadvies van de Vereniging 'Handelsrecht', samen met C.W. de Monchy, Zwolle 1991.

Timmerman, $L$. , Aansprakelijkheid van bestuurders van n.v.'s en b.v.'s; een overzicht van enige recente rechtspraak, TVVS 1991, blz. 197.

Timmerman, L., Fokker - Dasa, TVVS 1992, blz. 260.

Timmerman, L. (1993), De dubbelrol in het (vennootschaps)recht, in: De dubbelrol in het vennootschapsrecht, Uitgaven vanwege het instituut voor ondernemingsrecht, Rijksuniversiteit Groningen, nr. 16, Deventer 1993, blz. 1.

Treurniet, W.C. (1975), Departementale standpunten III, De NV 53 (1975), blz. 36.

Ulmer, P., Aufischtsratsmandat und Interessenkollision, NJW 1980, blz. 1603.

Uniken Venema, C.AE. (1970), Oligarchische regelingen ten aanzien van de grote N.V., De NV 48 (1970-71), blz. 130.

Uniken Venema, C.Æ. (1984), Raden van commissarissen en andere toezichthoudende structuren in het Nederlandse recht (beschouwingen naar aanleiding van de introductie van een Raad van Toezicht), De NV 62 (1984), blz. 49; 100; 109.

Ven, J.J.M. van der, Sociologische opmerkingen over de onderneming, De NV 26 (1948-49), p. 139.

Verdam, P.J., Taak en verantwoordelijkheid van de Commissaris, De NV 30 (1952-53), blz. 206.

Vijver, R. van de (1989), De commissaris Anno 1990, De Maris-bundel, Deventer 1989, blz. 211.

Vlas, P., Praktijkreeks IPR, deel 9, Rechtspersonen, Deventer 1993.

Viet, M.J. Van, Toetsing van commissarisbenoemingen door de Ondernemings- 


\section{LITERATUUR}

kamer, WPNR 5753 (1985), blz. 605.

Werkgroep Vennootschapsrecht, Advies inzake kwaliteitseisen voor commissarissen van structuurvennootschappen, De NV 53 (1975), blz. 19.

Wertheimer, H.W. (1975), Nu toch een belangen-commissaris in de structuurvennootschap?, TVVS 1975, blz. 293.

Westbroek, W. (1982), Statutaire casu quo contractuele regelingen voor de tussenkomst van derden bij geschillen, De NV 60 (1982), blz. 13.

Westbroek, W. (1987), De tiende druk van het Handboek Van der Heijden-Van der Grinten met supplement, De NV 65 (1987), blz. 178.

Werner, W. (1981), Aufsichtsratstätigkeit von Bankvertretern, ZHR 1981, blz. 252.

Wiethölter, R., Interessen und Organisation der Aktiengesellschaft, Karlsruhe 1961.

Winter, J.W. (1992), Concernfinanciering, Uitgaven vanwege het instituut voor ondernemingsrecht, Rijksuniversiteit Groningen, nr. 15, Deventer 1992.

Wolff, H.J. (1933), Organschaft und juristiche Person, Band I, Berlin 1933.

Wolff, M., On the Nature of Legal Persons, The Law Quarterly Review, Vol. CCXVI (1938), blz. 498. 


\section{Zakenregister}

Aanbeveling en bezwaar bij benoeming: 116, 142

Aandeelhouder

- -sbelang: 48

- commissie van -s: 119

- - en commissariaat: 58,129

- recht op informatie: 85

Aansprakelijkheid van commissarissen

- algemeen: 165

- bij faillissement: 181

- en onbehoorlijke taakvervulling: 167

- exoneratie: 177

- hoofdelijke -: 193

- verwijtbaarheid: 173

Accountant

- benoeming: 76

Advies

- algemeen: 21

Belang

- college van -: 16,22

- aandeelhouders- : zie aandeelhouder

- vân de vennootschap: zie vennootschappelijk belang

Bestuur

- daden van: 5, 27, 153

- mede-: 8

- vervanging van $-: 27$

Bestuurders

- aard rechtsverhouding: 60

- benoeming: 60

- ontslag: 68

- schorsing: 66

Bevoegdheden

- begrip: 17

- andere -: 88
Bezwaargronden: 142

Collegialiteit

- algemeen: 11

- collectieve verantwoordelijkheid: 193

Commissaris

- aard rechtsverhouding: 93, 169

- benoembaarheid: 128

- benoeming: $58,93,101$, 107

- gedelegeerde: 26,151

- honorering: 97

- overheids-: 154

- president-: 148

- schorsing: 104, 122

- ontslag: 104,124

Contracten

- benoemings- : 109

- m.b.t. bevoegdheden: 161

- m.b.t. bezwaargronden: 146

- van commissarissen met de vennootschap: 99

Décharge: 187

Deelrechtsorde: 4

Doel: 3

Exoneratie: zie aansprakelijkheid Gedelegeerde commissaris: zie commissaris

Geschillen

- beslechting door commissarissen: 90

Goedkeuring van besluiten

- algemeen: 77

- concern: 11,79

- goedkeuringsbesluit: 82

- prioriteit en -: 54 


\section{ZAKENREGISTER}

Incompatibiliteiten: 128

Informatie: $9,77,85,171$

Institutie: $39,108,138$

Jaarrekening: 71

Kwaliteitseisen

- bestuurders: 63

- commissarissen: 132, 156

Onafhankelijkheid: $58,129,200$

Ontheffing ex art. 156/266: 139

Orgaan

- begrip: 96

- facultatief -: 15,53

Overheidscommissaris: zie commissaris

President-commissaris: zie commissaris

Prioriteit: 54

Rechtspersoonlijkheid: 42

Regeringswaarnemer: 160

Samenstelling rvc: 126

Taak

- aanvullende -: 23
- algemeen: 1,167

- begrip: 23

- -verdeling: 12, 196

- -vervulling: $126,165,193$

Tegenstrijdig belang

- van bestuurders: 32

- van commissarissen: 200

- van overheidscommissarissen: 156

Toezicht

- begrip: 2

- onderwerp: 9

Toezichthoudende organen: 15

Vennootschappelijk belang: 42,200

Vertegenwoordiging

- der vennootschap door commissarissen: 32,88 ,

- - en orgaanbegrip: 96

Vervanging van het bestuur: 27 


\section{Curriculum vitae}

José María Blanco Femández werd geboren te Orense (Spanje) op 23 mei 1964. Ondanks diverse onvoldoendes voor lichamelijke opvoeding en godsdienst behaalde hij in 1982 te Palma de Mallorca zijn eindexamen Gymnasium. Hij studeerde Spaans recht en Nederlands recht. Thans Universitair docent Handelsen Ondernemingsrecht aan de Rijksuniversiteit Limburg. 
